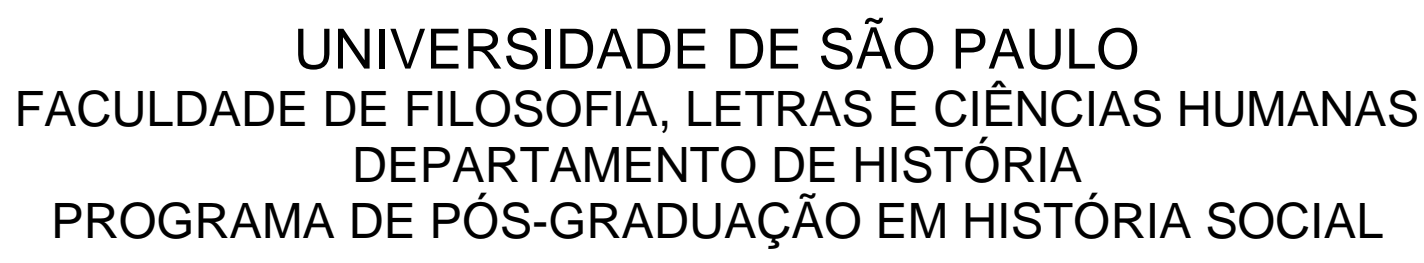

\title{
A construção da norma no movimento franciscano: Regulae e Testamentum nas práticas jurídicas mendicantes (1210-1323)
}

\author{
Veronica Aparecida Silveira Aguiar \\ Versão corrigida
}

\begin{abstract}
Dissertação apresentada ao Programa de Pós-Graduação em História Social do Departamento de História da Faculdade de Filosofia, Letras e Ciências Humanas da Universidade de São Paulo, para obtenção do título de Mestre em História.
\end{abstract}

Orientadora: Profa. Dra. Ana Paula Tavares Magalhães

São Paulo

2010 
Autorizo a reprodução e divulgação total ou parcial deste trabalho, por qualquer meio convencional ou eletrônico, para fins de estudo e pesquisa, desde que citada a fonte.

A versão original encontra-se na biblioteca da FFLCH - USP. AGUIAR, Veronica Aparecida Silveira

A construção da norma no movimento Franciscano: Regulae e Testamentum nas práticas jurídicas mendicantes (1210-1323) / Veronica Aparecida Silveira Aguiar; Orientador (a): Professora Doutora Ana Paula Tavares Magalhães Tacconi. São Paulo: dissertação de mestrado, 2010.

263 fls.

São Paulo: Universidade de São Paulo, 2010. 
Dedico este trabalho a meus pais,

Raquel e José Manoel, que sempre foram os meus maiores incentivadores e apoiadores. Graças ao esforço de ambos que eu venci mais uma etapa. 


\section{AGRADECIMENTOS}

Penso que seguir o caminho da pesquisa acadêmica é uma tarefa árdua que ultrapassa as fronteiras profissionais; é um investimento de anos de trabalho ou de uma vida que representa, acima de tudo, uma escolha individual madura e muito feliz. Entretanto, continuar os meus estudos, que culminaram na produção do presente trabalho, não teria sido um sucesso possível sem a presença de importantes pessoas e instituições, por isso volto a todos os meus mais sinceros agradecimentos. Além de tudo, foram inúmeros os obstáculos que se interpuseram no meu caminho, alguns deles frutos da minha própria imaturidade e desconhecimento. Muitas vezes vacilei, porém a força de vontade em superar as dificuldades sempre foi maior em todos os momentos da produção deste trabalho, graças ao apoio dos meus parentes e amigos.

Sem dúvida, uma das pessoas mais importantes que apareceu em minha trajetória acadêmica foi a Professora Ana Paula Tavares Magalhães Tacconi, orientadora desta dissertação de mestrado, que me introduziu no contato com as fontes, forneceu-me as bases da pesquisa e sempre estimulou o meu trabalho. De maneira muito atenciosa e profissional, soube com muita inteligência aguçar a minha curiosidade intelectual e contribuiu muito para o meu amadurecimento acadêmico. Devo a ela a aquisição de uma série de fontes escritas e bibliografia, essenciais, sem as quais esta pesquisa não teria encontrado meios para prosseguir. Agradeço eternamente a sua amizade, carinho e paciência ao longo da minha formação. Sempre muito presente na produção deste trabalho e com muita disposição para ensinar, sou grata pelas inúmeras orientações, diálogos e conselhos.

À FAPESP - Fundação de Amparo à Pesquisa do Estado de São Paulo, que me concedeu, durante o período de dois anos - de agosto de 2008 a julho de 2010 - bolsa de estudos referente a esta produção de mestrado. $O$ auxílio fornecido por essa instituição permitiu-me a aquisição de material bibliográfico e de subsídios para a participação em congressos e Grupo de Estudos de Medieval. Além de fazer publicações, pude freqüentar o estágio 
PAE (Programa de Aperfeiçoamento de Ensino) durante um ano e o auxílio também viabilizou a produção técnica do presente trabalho.

Ao Setor de Pós-Graduação do Departamento de História da Faculdade de Filosofia, Letras e Ciências Humanas da Universidade de São Paulo, instituição pela qual se processaram estes três anos de trabalho intensivo, registro aqui a minha gratidão pelo incentivo e valorização da pesquisa universitária no Brasil e, principalmente, pela excelente equipe da Biblioteca Florestan Fernandes da FFLCH-USP. Um agradecimento especial a toda a equipe do $\mathrm{CAPH}$ (Centro de Apoio à Pesquisa em História) da FFLCHUSP que sempre me auxiliou quando eu precisava. Sou grata pela incalculável disposição demonstrada. Agradeço também a toda a equipe da Biblioteca do Largo de São Francisco da Universidade de São Paulo pelo material fornecido.

Meus mais sinceros agradecimentos aos dois principais institutos de pesquisa sobre franciscanismo no Brasil, a equipe da Biblioteca do Seminário Seráfico São Fidélis de Piracicaba, em São Paulo e a equipe da Biblioteca do Instituto Teológico Franciscano de Petrópolis no Rio de Janeiro pelos materiais fornecidos e pela competência dos profissionais atestada quando fui pesquisar.

Ao Prof. Dr. Flávio de Campos, pelas sugestões sempre muito positivas e pela disponibilidade demonstrada ao integrar a banca de qualificação deste trabalho, apresentando contribuições construtivas e de grande valor para 0 encaminhamento da defesa. Gostaria de agradecer a sua postura assumida desde o Estágio do PAE, quando me acolheu com bastante profissionalismo e simpatia, na qualidade de meu supervisor, sempre com sugestões didáticas de suma importância, contribuindo em muito para o meu crescimento intelectual e pessoal.

A Profa. Dra. Susani Silveira Lemos França, pelas preciosas sugestões e pela disponibilidade demonstrada ao integrar a banca de qualificação deste trabalho, apresentando significativas contribuições de imenso valor para o encaminhamento da defesa. Agradeço a sua disposição e importante colaboração para o meu amadurecimento enquanto pesquisadora. Também sou grata pelos inúmeros congressos coordenados pela professora Susani dos quais pude participar e muito aprender.

Aos meus pais queridos, Raquel e José Manoel, agradeço eternamente pelo apoio incondicional que desde sempre têm dado à minha vida de estudos: 
graças ao estímulo de ambos cheguei até aqui com muita sabedoria e alegria. São os meus maiores incentivadores, que fizeram de mim o que sou hoje; aos meus queridos irmãos, André, Danilo e Juliano, pela compreensão demonstrada e pelo apoio carinhoso constante desde o início da minha carreira; às minhas queridas cunhadas, Marisa e Kátia, obrigada pelo incentivo e apoio; a minha querida avó, Isabel, que sempre tem acompanhado todos os meus passos, rezando e torcendo para que eu consiga realizar todos os meus sonhos; meus mais sinceros agradecimentos por tanto amor; aos meus doces sobrinhos, João Guilherme, Isabele e Heloisa, pela alegria e afeto que contribuíram muito com minha tarefa solitária de pesquisar. Agradeço também aos meus demais familiares, tias, tios, primos e primas que desde sempre me apoiaram ao longo deste trabalho com muito carinho e expectativa.

Um agradecimento muito especial à minha amiga Carolina Andrade Ramalho que, sempre muito disposta e companheira, me ajudou com 0 "abstract" deste trabalho. Um lindo agradecimento também à amiga Roberta Bottechia Lazzarini, que foi sempre muito atenciosa e companheira em todos os momentos. A mais sincera gratidão às amigas Heloisa Tatiana Sant'Ana da Silva Rondon, Michelle Reis e Simone Maria Bielesch, pela amizade e apoio nos momentos mais difíceis da minha vida, assim como pelo otimismo e companheirismo demonstrados. A amizade de todas constitui uma fonte de força, bem estar, alegria e saúde. Ter amigas compreensivas e torcedoras ajuda-me não só a viver mais, como também a viver melhor e a superar as dificuldades com paciência e sabedoria.

O meu mais sincero agradecimento aos amigos Wagner Aparecido Stefani, Enrique Hernando Zamora e Marcus Vinicius de Abreu Baccega pela amizade, carinho, conversas, livros, presentes, sugestões, paciência, risadas, trabalhos compartilhados, momentos de alegria e, principalmente, pela contribuição intelectual à minha formação. Sem dúvida, são anjos que apareceram na minha vida para trazer-me mais felicidade e amor fraterno.

À profa. Dra. Ivone Marques Dias, agradeço bastante pela amizade e disponibilidade demonstradas desde sempre, pelo incentivo, apoio, sugestões, livros, conversas e carinho expressados ao longo da minha formação. Agradeço também ao seu marido Paulo Aranha Dias pelo apoio técnico manifestado desde sempre ao meu trabalho, e ao seu filho, Paulo Vergílio 
Marques Dias, pela amizade, lealdade e companheirismo. Todos acompanharam de perto os meus primeiros passos no mundo acadêmico com muito carinho e incentivo. Também sou grata a Madalena Marques Dias que foi a minha professora de história no ensino médio e principal incentivadora da minha escolha profissional.

Ao Prof. Dr. Nachman Falbel pela erudição, simpatia e sugestões muito importantes que ajudaram na confecção deste trabalho. Desde a nossa primeira conversa foi muito receptivo e incentivador da minha pesquisa. Meus mais sinceros agradecimentos.

Sou muito grata à Prof. Dra. Terezinha Oliveira da UEM pelas nossas carinhosas conversas, livros e sugestões ao meu trabalho.

Um agradecimento muito especial ao Prof. Dr. Gerald Cresta da Universidade Católica de Buenos Aires pelos debates, sugestões positivas e trocas de informações que pudemos compartilhar por ocasião da participação de seu curso sobre filosofia franciscana na Universidade Estadual de Maringá.

Agradeço o apoio incondicional dado pelos meus companheiros de congressos, de sala de aula e de Grupo de Estudos Medievais na USP, Aline Cristina de Freitas Vian, Amanda Pereira Dias, Argentina Rozales, Diogo Comitre, Fernando Gasparetto, Kaili Takamori, José Luiz dos S. P. Filho, Márcia Gomes Fernandes, Marília Branco Pugliese, Marinalva Silveira Lima, Selene Candian dos Santos, Talita Cristina Garcia e Vanessa Amaral.

A todos os demais colegas de graduação e pós-graduação, que não foram aqui nomeados, mas têm acompanhado e encorajado tão de perto 0 trabalho desenvolvido, sempre com muito apoio e carinho, meus mais sinceros agradecimentos.

Sobretudo, agradeço a Deus por tantas oportunidades felizes e pessoas certas que foram postas no meu caminho, considero isso um verdadeiro privilégio e benção. 


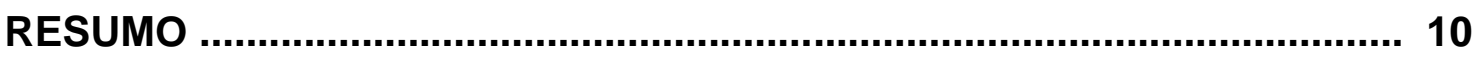

ABSTRACT

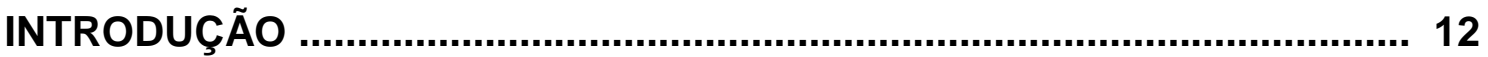

\section{CAPÍTULO I}

Francisco de Assis: Da fratenitas à Ordo

1.1 Assis: Da intuição ao projeto primitivo ………..................................... 19

1.2 A formação do movimento franciscano e a primeira geração menorita

1.3 Etapas da evolução da legislação Franciscana: uma releitura das regras .

1.4 Fora de Assis: expansão e consolidação da institucionalização ........ 79

1.5 Testamentum: a fase final da primeira geração menorita .................... 87

1.6 O problema da "herança jurídica" e da canonização de Frei Francisco 98

\section{CAPÍTULO II}

As contendas jurídicas sobre a pobreza franciscana: a relação RegraTestamento nas constituições papais

2.1 O Capítulo de Pentecostes e a bula Quo Elongati de 1230 de Gregório IX (1227-1241): o nascimento de um impasse

2.2 As mitigações de 1245 de Inocêncio IV (1243-1254): um novo conceito de pobreza

$2.3 \mathrm{O}$ ano de 1279: Nicolau III (1277-1280) e a anulação das declarações anteriores sobre a Regula

2.4 Novos impasses jurídicos da Norma sob o pontificado de Clemente V (1305-1314) e a Decretal Exivi de Paradiso de 1312 148

2.5 A crise institucional da Ordem: João XXII (1316-1334) e a negação do paradigma de pobreza franciscana em 1323 


\section{CAPÍTULO III}

Os debates internos à Norma: interpretações da Regra e do Testamento segundo dois Frades menores

3.1 O generalato de Frei Elias (1232-1239): o enquadramento institucional 172

3.2 A questão da pobreza na obra Expositio super Regulam Fratrum Minorum da década de 1260 de Boaventura de Bagnoregio (1221-1274) 184

3.3 Pedro de João Olivi (1248-1298) e a questão usus pauper na norma 195

3.4 O princípio da intocabilidade da Regra na obra Expositio super Regulam Fratrum Minorum de 1323 de Angelo Clareno (1245-1337) 201

3.5 Os limites da pobreza normativa franciscana: dissidência e ortodoxia 211 
O presente trabalho teve como objetivo avaliar a evolução das práticas jurídicas no movimento Franciscano e, para esse fim, partimos da proto-Regra de 1210, Regula non bullata de 1221, da Regula bullata de 1223 e do Testamentum beati Francisci de 1226. Ao estudarmos a construção da norma no movimento da primeira geração menorita, demonstramos que a pobreza franciscana e a Imitatio Christi, que tem por base as Regras e o Testamento, foram adequados paulatinamente ao modelo jurídico da Igreja da época, ajustando-se ao Corpus Juris Canonici e ao IV Concílio de Latrão, igualando-se às demais instituições religiosas tradicionais. Para o período de 1230 a 1323, foi imprescindível avaliar a dissidência franciscana dos "resistentes" a esse ajustamento, a qual influenciou as relações sociais e políticas entre a Igreja e a Ordem.

Este trabalho de mestrado também discutiu a institucionalização do movimento Franciscano na época de vida de Francisco de Assis (1182-1226) e as contendas jurídicas em torno dos seus escritos legislativos formuladas posteriormente à sua morte. Para fazer tal análise, avaliamos de maneira serial um conjunto de bulas exegéticas sobre a Regra e o Testamento formuladas por diversos papas. Ademais, os debates internos à Norma gravitaram em torno de dois frades de atuação significativa para a Ordem, a saber, Boaventura de Bagnoregio (1221-1274) - que, ao longo de seu generalato (1257-1274), introduziu mudanças institucionais importantes na Ordem - e Angelo Clareno (1245-1337), um dos "dissidentes" do movimento Franciscano, originário da região da Marca de Ancona, lugar de importante produção teórica por parte de uma série de frades. A partir da análise dos aspectos acima relacionados, o principal intuito deste trabalho será aquele de verificar a evolução do conceito de pobreza franciscana no âmbito das discussões jurídicas da Igreja e da Ordem dos Frades menores.

Palavras-chave: Pobreza - Igreja - Regras e Testamento - Imitatio Christi movimento Franciscano 


\section{ABSTRACT}

The present work aims at evaluating the evolution of the judicial practices in the Franciscan movement and, to do so, we departed from the proto-Rule of 1210, the Regula non bullata of 1221, the Regula bullata of 1223 and from the Testamentum beati Francisci of 1226. By studying the construction of the norm in the first minorite generation, we demonstrated that the Franciscan poverty and the Imitatio Christi, which have the Rules and the Testament as their base, were adapted to the judicial model of that time, gradually adjusting itself to the Corpus Juris Canonici and to the IV Lateran Council, equalizing itself to the traditional religious institutions. The period from 1230 to 1323 was crucial for the research because we evaluated the Franciscan dissidence of the "resistants" to this adjustment, which influenced the political and social relations between the Church and the Order.

This Master's dissertation also discussed the institutionalization of the Franciscan Movement during Francis of Assisi's life and the judicial dissents about his legal writings formulated after his death. In order to analyze this, we carried out a serial evaluation of a set of exegetic bulls about the Rule and the Testament formulated by several popes. Moreover, the internal debates to the Norm gravitated around two friars who had significant roles to the Order: Bonaventure of Bagnoregio (1221-1274) - who, along his generalate (12571274), introduced important institutional changes in the Order - and Angelo Clareno (1245-1337), one of the "dissidents" from the Franciscan movement, who comes from the region of Marca of Ancona, a place of important theoretical production by several friars. By analyzing the aspects above, the main goal of this dissertation will be verifying the evolution of the concept of the Franciscan poverty in the context of the judicial discussions of the Church and the Minor Friars' Orders.

Key-words: Poverty - Church - Rules and Testament - Imitatio Christi Franciscan movement 


\section{INTRODUÇÃO}

A presente dissertação de mestrado tem como objetivo principal entender a evolução ${ }^{1}$ jurídica do debate do conceito de pobreza franciscana emanada a partir dos documentos legislativos da Ordem dos Frades menores. O recorte metodológico insere-se na problemática construção da norma no movimento Franciscano e na relação Regra-Testamento que se iniciou em 1230, consistindo numa contenda jurídica em torno da pobreza franciscana que ultrapassou o século XIII. Apesar do período cronológico abordado ser abrangente, a análise restringe-se somente ao enfoque jurídico que gravita na questão da paupertas franciscana de 1210 a 1323. Para compreender este debate, partirmos do processo da construção da norma e do significado do Testamento para a primeira geração menorita e suas consequências. Nesta dissertação é no capítulo um que se concentra o cerne de todo o trabalho, sendo os capítulos dois e três complementares. Assim, no capítulo um a ênfase recai sobre o nosso corpus documental; são eles, a saber, a proto-Regra de 1210, a Regula non bullata de 1221, a Regula bullata de 1223 e o Testamentum beati Francisci de 1226.

A primeira reunião do nosso corpus documental foi realizada por Lucas Wadding no ano de 1623, sob o título de Opuscula, título inapropriado. As duas primeiras edições críticas das nossas fontes foram realizadas por Leonhard Lemmens junto aos padres do Colégio São Boaventura de Quaracchi (Firenze) e por Heinrich Boehmer em Tubingen (Alemanha) ${ }^{2}$. Após a publicação destas edições surgiu um despertar de interessados nas fontes franciscanas; eram filósofos, historiadores, teólogos, que se animaram em pesquisar uma das figuras mais populares e de caráter universal do medievo, Francisco de Assis, que ultrapassou em importância a delimitação do seu período cronológico.

Em 1976, surgiu um importante compêndio de estudos científicos sobre os escritos de Francisco, o volume do Corpus des sources franciscaines, com

\footnotetext{
${ }^{1}$ O termo evolução na presente dissertação é usado no sentido de desenvolvimento do debate jurídico da pobreza dentro do movimento Franciscano, objetivamos mostrar as etapas de mudanças e não entendemos essas mudanças no sentido de aperfeiçoamento ou incorporação de novas conquistas.

${ }^{2}$ Ao longo desta dissertação utilizamos as fontes em latim da publicação de MENESTÒ, Enrico \& BRUFANI, Stefano (org.). Fontes Franciscani. Assis: Edizioni Porziuncola, 1995, p. 3.
} 
quadros comparativos da Opuscula, com direção de Jean-François Godet e Georges Mailleux; a Concordantiae verbales da mesma Opuscula com a Editio textus com direção de Giovanni M. Boccali; e finalmente "a última edição", a nova edição crítica da mesma Opuscula com direção de Kajetan Esser por conta dos Padres de Quaracchi (transferidos para Grottaferrata - Roma); a última revisão de 1989 de Engelbert Grau foi refeita pela edição das Fontes franciscani de 1995, a qual utilizamos nesta dissertação.

Como grande parte dos homens do medievo, quando afirmamos que dos Escritos atribuídos a Francisco de Assis provavelmente bem poucos devem ter saído de suas próprias mãos significa que ele participou dos escritos, mas não foi o único redator ou protagonista. No seu Testamento, aparece esta revelação: "E eu fiz escrever em poucas palavras e de modo simples, e o senhor papa as confirmou". Assim, a construção da norma no movimento Franciscano não foi um processo fácil e indolor, como nos assinala André Vauchez, foi uma "dolorosa normatização" da fraternita, que se iniciou em 1208, culminando na redação da Regra não bulada de 1221 e da Regra bulada de 1223 .

Ao nos deparamos com a Regra Franciscana, não encontramos uma simples regra religiosa para frades fechados em conventos, mas um projeto de evangelização ou ideal de vida apostólica para a sociedade citadina do século XIII centrado na experiência de vida de Francisco de Assis e companheiros, que pretendiam ditar um modo de vida para a conduta dos fiéis daquele período com o objetivo de atingir a perfeição evangélica de toda a societas christiana. Os textos procuraram acentuar o caráter disciplinador da pobreza, consistindo em uma reação aos avanços da riqueza da Igreja Romana e da burguesia italiana, com o intuito de evangelizar, moralizar, "converter" e dar participação religiosa aos leigos das cidades italianas. Por isso, o modelo de Regra adotado é apostólico, contendo as diretrizes fundamentais da vivência da pobreza para os clérigos e leigos franciscanos.

Além disso, no século XIII, o papel das normas foi o de adaptação à vida da urbe medieval onde todas as profissões e situações sociais eram rigorosamente regulamentadas; como exemplo, as profissões lícitas, a prostituição, as instituições assistenciais, as ordens de cavalaria, a vida dos leprosos e outros proscritos da sociedade medieval. A necessidade de 
regulamentação advinha do fato de a cidade representar um lugar propício à propagação de heresias e movimentos de rebeldia. As cidades foram um ponto de encontro dos diversos grupos existentes naquela sociedade; era o lugar onde circulavam as ideias e onde se reunia um maior número de pessoas, onde se albergavam os viajantes; logo, um carrefour de ideias, às vezes perigosas.

No momento inicial da preparação deste trabalho manifestaram-se duas ideias: exclusão e inclusão. A primeira nos diz respeito às passagens bíblicas nos quais Cristo foi mencionado pregando aos "excluídos" ou marginalizados da sociedade do Novo Testamento. Já a segunda ideia nos remete ao convite do próprio Cristo de que todos podem conhecer o Pai e, através dele, o convite dirige-se a todos, inclui todos no projeto de salvação. Algo semelhante acontece no movimento Franciscano que propõe como projeto específico a pobreza e a Imitatio Christi, um processo de inclusão aos excluídos, não só nas fronteiras da cristandande latina, mas também fora dela, como, por exemplo, a pregação no mundo muçulmano.

Desta forma, Francisco colocou como centro de seu movimento a imitação da vida de Cristo, a observação do Evangelho e a pobreza. O cristocentrismo franciscano está intimamente ligado à idealização e ao estado de espírito da recordação das passagens do Deus-homem na terra, imitando Cristo em suas ações e exemplos através de uma pobreza diferente da tradição monástica. Veremos que a pobreza na tradição jurídica do movimento Franciscano configurou-se num conceito constantemente reformulado e debatido pelos agentes internos e externos ao movimento. Por isso, optamos pelo discurso jurídico nesta dissertação porque entendemos ser o mais representativo na construção da identidade do movimento Franciscano.

A Regra Apostólica ou franciscana de 1223 apresenta uma nova estrutura jurídica e é resultado em parte da discussão de vários Capítulos dos Frades; ela não resulta da formulação direta de Francisco, mas de um conjunto de participantes, inclusive do papa Gregório IX (1227-1241), que na época redacional era o cardeal protetor Hugolino de Óstia (1217-1227) e de frei Cesário de Espira, principalmente no tocante às passagens bíblicas do Novo Testamento. Esta Regra foi aprovada pelo papa Honório III por meio da bula Solet annuere, em 29 de novembro de 1223. 
A Regra de 1221 tinha vinte e três capítulos, enquanto a Regra de 1223 contava apenas com doze capítulos. Tivemos uma redução dos capítulos e do texto que trouxe algumas consequências para o movimento Franciscano. No ano de 1226, Francisco faleceu em 3 ou 4 de Outubro, depois de ter ditado o seu Testamentum, texto de final de vida, também imprescindível para a compreensão de nosso trabalho. O Testamento era um legado deixado por Francisco para a posteridade, por isso é necessário vê-lo como um gênero específico.

Para melhor compreender a construção da norma no movimento Franciscano, utilizamos o conceito de metamorfoses ${ }^{3}$ no sentido de que existiram várias fases, com transformação gradual, de forma artificial, porque houve tensões e conflitos de dois projetos diferentes. O primeiro era o projeto primitivo de Francisco e seus primeiros companheiros, a fraternitas, que logo evoluiu para uma Regra com um novo modelo, base jurídica da Ordo, com uma hierarquia específica e enquadramento dado pela Igreja que, por sua vez, tinha um outro projeto para as Ordens mendicantes e a cristandade latina.

$\mathrm{Na}$ historiografia atual, podemos, grosso modo, dividir as pesquisas entre os historiadores de Francisco que se aproximam e os que se distanciam dos estudos de Paul Sabatier. Sabatier e sua Escola de Estudos Franciscanos marcaram o final do século XIX e abriram para as pesquisas atuais; ele foi o primeiro historiador a fazer uma análise mais profunda das Regras e Testamento, assinalando o problema da institucionalização do movimento Franciscano com a obra Vie de Saint François d'Assise ${ }^{4}$, publicada no ano de 1894 em Paris, que marcou uma nova época no campo do franciscanismo e dos estudos histórico-críticos das fontes franciscanas. ${ }^{5}$ Nesta dissertação, priorizaremos a abordagem historiográfica italiana e francesa atual para compreendermos os processos jurídicos e de mudanças do franciscanismo.

\footnotetext{
${ }^{3}$ Conceito inventado pelo historiador italiano Grado Giovanni Merlo para designar as mudanças irreversíveis da Ordem Franciscana ao longo da sua história. Cf. MERLO, Grado Giovanni. Em nome de São Francisco. História dos Frades Menores e do franciscanismo até inícios do século XVI. Trad. Ary E. Pintarelli. Petrópolis: Vozes/FFB, 2005.

${ }_{4}$ Ver SABATIER, Paul. Vida de São Francisco de Assis. Bragança Paulista: Editora universitária de São Francisco, Instituto Franciscano de Antropologia, 2006, introdução.

${ }^{5}$ Até nos dias atuais, a historiografia conservadora continua desmerecendo as pesquisas de Sabatier sem levar em conta o período da sua produção no final do século XIX, representantes desta linha são/foram Martino Conti, Malcolm Lambert, Stanislao da Campagnola, Kajetan Esser, entre outros. Ver a introdução de SABATIER, Paul. Op. cit.
} 
Sabemos que existe uma extensa bibliografia sobre o franciscanismo, porém utilizaremos na dissertação apenas alguns autores considerados mais significativos quanto ao tema do nosso estudo, a saber; Agostino Paravicini Bagliani, Andrea Tabarroni, André Vauchez, Brenda Bolton, Carlo Paolazzi, Carlos Mateo Martínez Ruiz, Christian Trottmann, Damien Vorreux, David Burr, David Flood, Edith Pásztor, Enrico Menestò, Fernando Uribe, Franca Allegrezza, Francis Rapp, Giovanna Casagrande, Grado Giovanni Merlo, Giulia Barone, Giulio Basetti-Sani, Giovanni Miccoli, Jacques Le Goff, John Moorman, Herbert Grundmann, Kajetan Esser, Lothar Hardick, Luigi Pellegrini, Lydia von Auw, Malcolm Lambert, Maria Giuseppina Muzzarelli, Martino Conti, Michel Mollat, Nachman Falbel, Nino Scivoletto, Omer Englebert, Ovidio Capitani, Paul Sabatier, Pietro Maranesi, Roberto Lambertini, Rafaelle Pazzelli, Raoul Manselli, Raymonde Foreville, Sandro Carocci-Marco Venditelli, Stanislao da Campagnola, Stefano Brufani, Theophile Desbonnets, Werner Maleczek e Willibrord-Christian Van Dijk.

Esta evolução do movimento era inevitável, porque uma série de transformações lhe impunha mudanças, que visavam a preservar, ao mesmo tempo que modificavam a fraternitas franciscana. A Ordem Franciscana passou por diversas metamorfoses que alteraram o seu interior, propiciando 0 surgimento de tensões internas e divisões de grupos que de diferentes maneiras interpretaram as Regras e o Testamento. Em parte, a diversidade das leituras propiciou as divisões da Ordem em muitas ramificações, até um certo ponto distintas, se pensarmos nos Observantes e Capuchinhos, detentores de uma hierarquia própria a partir do século XVI.

Como metodologia da análise textual, comparamos as permanências e rupturas do conteúdo das duas Regras e do Testamento no capítulo um, visto que os três documentos representam uma unidade para a formação da primeira geração menorita. Isto, sem perder de vista a contextualização do movimento Franciscano num momento em que as cidades estavam reflorescendo e as Regras junto com o Testamento possuiam uma intersecção com as normatizações jurídicas urbanas e pontifícias do início do século XIII. Este conjunto de documentos representa o "código genético do franciscanismo" segundo Grado Merlo. Depois, no segundo capítulo, a abordagem é delimitada pelas principais constituições papais acerca da pobreza da Regra e o debate 
gravita em torno do desenvolvimento jurídico normativo; foram selecionados as seguintes bulas exegéticas, a saber: a Quo elongati de 1230, de Gregório IX (1227-1241), a Ordinem vestrum de 1245, de Inocêncio IV (1243-1254), a Exiit qui seminat de 1279, de Nicolau III (1277-1280), a Exivi de paradiso de 1312 , de Clemente V (1305-1314), a Ad conditorem canonum de 1322 e a Cum inter nonnullos de 1323, de João XXII (1216-1334) - que analisamos de forma serial.

O terceiro capítulo desta dissertação girou em torno do conceito de usus pauper, do direito civil de propriedade e uso, de Boaventura de Bagnoregio (1221-1274) - que, ao longo de seu generalato (1257-1274), introduziu mudanças institucionais importantes na Ordem - e da interpretação de usus de Angelo Clareno (1245-1337), um dos "resistentes" ao enquadramento do movimento Franciscano, originário da região da Marca de Ancona, lugar de importante produção teórica por parte de uma série de frades, dois representantes distintos da Ordem que levantaram comentários específicos em torno da paupertas da Norma através das suas Expositio. Ambos representaram grupos distintos na Ordem, o primeiro, representante dos frades da Comunidade e o segundo, representante dos Espirituais umbros, um dos frades "resistentes" à interferência romana na Ordem.

No Brasil, os estudos das fontes franciscanas ganharam novo impulso com o Concílio Vaticano II, partindo da proposta de as Ordens religiosas voltarem seus apostolados para as fontes buscando as suas origens. Fruto desta proposta são as pesquisas do Frei Leonardo Boff ${ }^{6}$ dos anos 1970 à 1990, o fundador da "Igreja dos pobres" com a proposta de defender os oprimidos por meio da simplicidade dos primeiros tempos apostólicos, resultante do movimento da "teologia da libertação" na América Latina, que tem como pressuposto o reviver a mensagem de Francisco de Assis nos dias atuais, combatendo a pobreza não voluntária.

Todos os frades historiadores do movimento Franciscano atual ou do passado possuem um diálogo bem localizado na época em que escreveram e com a história contemporânea da Igreja. Muitas vezes, os franciscanos historiadores estiveram ou estão envolvidos com obras sociais do presente, por

\footnotetext{
${ }^{6}$ BOFF, Leonardo. Igreja, carisma e poder: ensaios de eclesiologia militante. Petrópolis: Vozes, 1982; A análise da proposta de Leonardo Boff é comentada no livro mais recente da historiografia francesa sobre Francisco de Assis. Cf. VAUCHEZ, André. François d'Assise. Entre histoire et mémoire. Paris: fayard, 2009, p. 357.
} 
isso a análise de suas obras exige muita cautela para não aumentar e nem diminuir o valor das suas pesquisas que, enquanto produção historiográfica, dialoga em paralelo com a produção acadêmica.

A partir destas considerações, pretendemos verificar a evolução do conceito de pobreza franciscana no âmbito das discussões jurídicas da Igreja e da Ordem dos Frades Menores de 1210 a 1323. Analisando os aspectos acima relacionados, consideramos que a construção da norma na primeira geração menorita deve ser pensada no sentido coletivo e não como parte da individualidade de Francisco de Assis; por isso o uso do termo movimento Franciscano ao longo desta dissertação. 


\section{CAPÍTULO I}

Francisco de Assis: Da fraternitas à Ordo

\subsection{Assis: Da intuição ao projeto primitivo}

A cidade de Assis $^{7}$ na qual nasceu Francisco é de origem romana, pátria do poeta Propércio. Devido a sua posição geográfica à meia costa do Monte Subásio, situa-se num ponto de grande importância estratégica para o controle das estradas que de Foligno levam a Perúgia ou que chegam até Espoleto. Na segunda metade do século XII, constituía, num ponto avançado, a cunha do ducado imperial de Espoleto em direção a Perúgia que, junto com grande parte da Úmbria, estava sob a influência da Igreja Romana ${ }^{8}$.

A família de Francisco não era originária de Assis. O pai, Pedro Bernardone, provinha de Lucca, onde exercia o comércio de tecidos de luxo, um dos comércios mais lucrativos da época. Ele tinha loja em Assis, na qual exercia a profissão de comerciante, dando continuidade aos negócios tradicionais da família. A mãe, Donna Pica, era de origem aristocrática e originária ou da Provença ou de Lucca ${ }^{9}$; Provavelmente Pedro a conheceu durante uma de suas viagens de negócios. Pedro e Pica tiveram dois filhos: Angelo e Francisco ${ }^{10}$. Pedro Bernardone viajava constantemente para a

\footnotetext{
${ }^{7}$ Conforme os postulados de Fernando Uribe a cidade de Assis tem origem longínqua. "Más probablemente, los orígenes históricos de Asís se remontan a las antiguas tribus de los umbros, quienes hubieron de compartir el poblado con los etruscos cuando éstos invadieron y dominaron el lugar desde el siglo IV A.C. Del período de la dominación estrusca se conservan aún algunos vestigios en la muralla, cerca de la puerta san Giacomo y en la via Portica, cerca de la torre comunal. Los corredores subterráneos que van del centro de la ciudad hacia la Rocca son también de esta época. A fines del siglo III A. C. se inició la dominación romana después de la batalla de Sentino (295 A. C.), en la que los etruscos y sus aliados los umbros fueron vencidos por el cónsul Q. Fabio y asimilados a la república de Roma."

URIBE, Fernando. Por los caminos de Francisco de Asis. Oñate: Franciscana Aránzazu, 1990, p. 25.

Cf. MANSELLI, Raoul. São Francisco. Petrópolis: Vozes,1997, p. 30. Para situar a região da Úmbria e a cidade de Assis ver mapas 1, 2 e 3 em anexo.

9 Trata-se de dados imprecisos, não dispomos de fontes para afirmar nem a sua origem provençal, nem a sua proveniência de Lucca, ambos são hipóteses não muito comprovadas pela historiografia.

${ }^{10}$ Ver ROSSETTI, Felice. I genitori dei San Francesco. Città di Castello: edizioni il leccio, 1992. MANSELLI, Raoul. Op. cit., p. 38. FALBEL, Nachman. Os Espirituais Franciscanos, São Paulo: EDUSP, FAPESP, Perspectiva, 1995, p. 3.
} 
França, tornara-se um importador de tecidos de Flandres, que depois revendia, como era o costume, com largas margens de lucro.

II raggio della sua attività non si restringeva alle città viciniori, ma si estendeva alle città d'oltralpe, fino a Sciampagna (Champagne), Provins, Troyes, Saint-Ayoul, Bar-sur-Aube, città limitrofe, dove si svolgevano le fiere internazionali, a turno, sì da rendere continuo il mercato. ${ }^{11}$

Tanto a historiografia quanto as fontes concordam que Francisco Bernardone provinha de família rica. Para Raoul Manselli, Francisco de Assis pertencia ao mais alto nível da classe mercantil de sua cidade, ou seja, a sua família era riquíssima. Assim, o pai não era um simples artesão, mas um rico mercador em contato com a efetiva circulação de moedas, particularmente em Assis e na Úmbria. Segundo o francês Desbonnets ${ }^{12}$, certamente o pai de Francisco não vivia apenas do lucro da venda de tecidos buscado nas feiras da Champagne, porque a clientela potencial de um comerciante de tecidos que residia em Assis não seria suficiente para enriquecê-lo de tal maneira, por isso provavelmente vivia também de empréstimos usurários, o que em parte explicaria a aversão de Francisco ao dinheiro e resolveria o problema "vivia em pecado" posto por Francisco no seu Testamento.

A respeito da formação do movimento Franciscano seguiremos 0 procedimento de confrontar a relação entre as Regras e o Testamento $^{13}$, de modo que resulte num quadro historicamente válido e persuasivo. Para isso, a nossa preocupação principal insere-se na evolução da discussão da pobreza normativa franciscana derivada dos principais textos legislativos acima citados que nos servem de base para um melhor entendimento da passagem da fraternitas à Ordo e para demonstrar a consequência disso no movimento Franciscano e a sua relação com as normatizações da Igreja Romana. Assim,

\footnotetext{
${ }^{11}$ ROSSETTI, Felice. Op. cit., p. 32.

${ }^{12}$ Cf. DESBONNETS, Theophile. Da intuição à instituição. Petrópolis: Vozes, 1987, p. 26.

${ }^{13}$ Sem perder de vista as observações de Carlo Dolcini em relação as hagiografias mas que são válidas para as outras fontes franciscanas. Mesmo após cem anos da biografia de Francisco escrita pelo francês protestante Paul Sabatier em 1893, ainda não é dada por encerrada a "questão franciscana", talvez nunca poderá ser resolvida porque a história de Francisco e do movimento Franciscano apresentam-se com uma série de problemas específicos, que não existe a possibilidade de reduzi-los ou encerrá-los. DOLCINI, Carlo. "Francesco d'Assisi e la storiografia degli ultimi vent'anni: problemi di metodo." In: Frate Francesco d'Assisi. Atti del XXI Convegno internazionale, Assisi, 14-16 ottobre 1993. Spoleto: Centro italiano di studi sull'alto Medioevo, 1994, p. 5.
} 
a partir das Regras e do Testamento, que consistem nos principais escritos legislativos de Francisco de Assis, exporemos a passagem da fraternitas à Ordo, da intuição à instituição, fruto de complexas tensões, conflitos internos e resistências que ultrapassaram o século XIII.

Francisco de Assis foi o primogênito do casal Bernardone e nasceu em 1181 ou $1182^{14}$, em Assis. O pai viajava a negócios pela França; na sua ausência, a mãe o teria batizado com o nome de João Batista. Não se sabe exatamente a data da mudança do nome de João Batista para Francisco, nem o porquê desta mudança. Para Jacques Le Goff, existem três hipóteses: a primeira teria sido o pai que, ao voltar do país do qual teria tirado o nome, deu o nome Francisco, hipótese mais aceita na historiografia; a segunda, seria uma homenagem prestada à mãe, que seria francesa (da Provença); e a terceira seria pelo fato da paixão juvenil de Francisco pela língua francesa, devido à estima que possuía por essa cultura. ${ }^{15}$

Em relação à infância e juventude de Francisco, as informações são bastante escassas. Os historiadores tiram as informações basicamente das hagiografias ${ }^{16}$. Entretanto, o objeto de estudo desta dissertação são os escritos legislativos atribuidos a Francisco. Deste modo, afirmamos apenas que Francisco Bernardone teria sido educado na "cultura" e no idioma francês, porque talvez fosse falado em família como nos aponta Sabatier ${ }^{17}$. Do latim, ele tinha um conhecimento parco em nível de cultura de um comerciante, mas diante da preparação de um clérigo de boa formação, era considerado muito modesto. Do mesmo nível devia ser o seu francês; seria um conhecimento não escolar, mas prático, ligado ao mundo dos negócios e ao mundo dos divertimentos. ${ }^{18}$ De qualquer modo, não constitui tarefa fácil referir-se à vida de Francisco e a sua experiência cristã antes da conversão, segundo Desbonnets 19. É muito complexo identificar com exatidão o que se passou da infância até

\footnotetext{
${ }^{14}$ A data de nascimento de Francisco de Assis oscila entre os anos de 1181 e 1182 . A historiografia chegou a estas datas a partir da data da morte, contando os anos de vida que the são atribuídos pelas fontes.

${ }^{15}$ Cf. LE GOFF, Jacques. São Francisco de Assis. Rio de Janeiro: Record, 2001, pp. 58-59.

${ }^{16}$ Ver MICCOLI, Giovanni. Francisco de Assis: Realidade e memória de uma experiência cristã. Petrópolis: Vozes, 2004, pp. 203-204.

17 Cf. SABATIER, Paul. Vida de São Francisco de Assis. Bragança Paulista: Editora universitária de São Francisco, Instituto Franciscano de Antropologia, 2006, p. 96.

${ }^{18}$ Cf. MANSELLI, Raoul. Op. cit., p. 41.

19 Um estudo significativo a respeito das Legendas franciscanas situa-se no apêndice da pesquisa do frei francês Theophile Desbonnets, o autor esboça vários esquemas, identificando
} 
os vinte e cinco anos (a maioridade para o homem medieval) de Francisco. Deduzimos somente que vivia como a juventude de sua época e da sua esfera social. É pouco provável conseguir recuperar alguma informação além desta.

Durante a sua juventude, na cidade de Assis, havia a luta entre os partidários do papa e os partidários do imperador (o chefe do Sacro Império Romano-Germânico) entre os guelfos e gibelinos; também continuava o conflito entre a nobreza das velhas famílias feudais e a nova burguesia mercadora; as comunas urbanas procuravam autonomia a fim de se livrarem da tutela da nobreza latifundiária. Em 1198, Lotário di Segni (1160/1161?-1216) subiu ao trono papal como Inocêncio III (1198-1216), um ano após a morte de Henrique VI. Iniciou uma política de reconquista de territórios perdidos ao império e um dos aspectos desta política foi a proteção das cidades italianas. Na Alemanha havia dois candidatos ao trono imperial: o gibelino Filipe de Suábia, filho de Barba-ruiva e irmão de Henrique VI, e o guelfo Otto de Brunswick.

Com a morte de Henrique VI em 1196 e, pouco tempo depois, da sua esposa Constança, o papa Inocêncio III ficou como tutor do príncipe Frederico Rogério (futuro Frederico II), herdeiro do trono, que era neste momento menor de idade. O papa aproveitou a ocasião para um ajuste de contas político, dentre os quais aproveitou para recuperar o ducado de Espoleto ${ }^{20}$.

Em 1200, na ausência do duque de Espoleto, Conrado de Irslingen, os assisienses atacaram a fortaleza germânica de Rocca Maggiore ${ }^{21}$ e a

as influências hagiográfica franciscana de cada bio-hagiografia franciscana. A sua pesquisa continua a ser muito atual. Para este trabalho, interessa-nos o seu estudo minucioso e criterioso das fontes jurídicas franciscana que serve-nos de base para a análise da passagem da fraternidade à Ordem religiosa. DESBONNETS, T. Da intuição à instituição. Petrópolis: Vozes, 1987, p. 21.

20 Sobre a cidade de Espoleto Uribe tece os seguintes comentários: "Los orígenes de Espoleto se remontan alrededor del siglo X A.C., cuando fue fundada por los pueblos umbros. En el siglo VII pasó bajo el dominio de los etruscos y en el III bajo los romanos, quienes hicieron de ella un importante centro militar, cultural y religioso. [...] Entre los siglos XI y XII, los emperadores concedieron frecuentemente el ducado en feudo a sus vasallos alemanes, uno de los cuales fue Conrado de Urslingen, quien en 1198 fue obligado a entregarlo al papado en la persona del cardenal Gregorio Crescenzi. Otón IV lo retomó en 1210 y se lo entregó a Rinaldo, hijo de Conrado de Urslingen. En 1231 el papa Gregorio IX obligó al emperador Federico II a deponer a Rinaldo después de muchas luchas y tensiones y el ducado pasó definitivamente bajo el dominio del papado."

URIBE, Fernando. Op. cit., p. 143.

${ }^{21}$ Para Uribe Rocca Maggiore foi um ponto estratégico importante. "Pero la primera mención histórica de la Rocca sólo se remonta al año 1174, cuando un príncipe-arzobispo de Maguncia llamado Cristiano, ocupó a Asís por orden del emperador Barbarroja para sofocar la sublevación del pueblo. En castigo, el emperador entregó en feudo el condado de Asís al duque de Espoleto Conrado de Lutzen (o Urslinguen), el cual ocupó su fortaleza." 
destruiram; foi aprisionada a guarnição alemã e os assisienses recusaram a entregá-los ao papa Inocêncio III. Assim, é provável que Francisco tenha participado destes conflitos, ainda mais porque o ideal cavalheiresco da época com grande probabilidade atingia a juventude assisiense. ${ }^{22} \mathrm{Em}$ resumo, os habitantes de Assis aproveitaram a conjuntura política para se livrarem do jugo do imperador e realizarem a ambição de chegar a ser uma comuna independente. Por isso, tomaram a Rocca, destruiram-na e fortificaram os muros da cidade de Assis. A partir destas informações, deduzimos que em nenhum momento a cidade de Assis precisava tanto de um Santo como agora para adquirir a sua autonomia em relação à Perugia e Espoleto, já que Assis se localizava no meio da passagem de ambas as cidades que viviam em guerra.

Com isso, os nobres de Assis que se identificavam com os interesses alemães foram expulsos e muitos fugiram para Perugia ${ }^{23}$, onde se encontrava 0 centro do poder imperial. Nesta ocasião, Perugia e Assis declararam guerra entre si, sucederam batalhas na Ponte San Giovanni sobre o Tibre, mas a cidade de Perugia venceu o conflito. A paz entre as duas cidades só foi concluída no ano de 1203.

Para Sabatier, quando Francesco Bernardone se encontrava a caminho de Espoleto, caiu doente e teve uma visão que o levou a reconsiderar seus planos e voltar a Assis. A partir deste momento é que o pensamento religioso pareceu surgir nele ${ }^{24}$. Em 1205, iniciou uma meditação acerca do caminho de vida que levava e decidiu-se por uma nova vida bem diferente da que vivia até aquela data ${ }^{25}$.

$\mathrm{Na}$ verdade, não sabemos claramente sobre a saída de Francisco da sociedade leiga, da ordo laicorum, no sentido canônico do termo, para tornar-

\footnotetext{
URIBE, Fernando. Op. cit., p. 42.

${ }^{22}$ LE GOFF, Jacques. Op. cit., p. 60.

${ }^{23}$ Sobre a cidade de Perugia, Uribe informa-nos: "El documento escrito más antiguo que habla de Perusa son unos fragmentos de la obra de Catón $(<<L$ Los Orígenes $>>)$ en donde dice: $<<$ Sarciantes Perusiam condiderunt $>>(<<$ Los de Sarsinia fundaron a Perusa $>>$. Sarsinia era un pueblo de la Umbría, donde nació Catón). [...] Fue guelfa y, por tanto, partidaria del papa en las luchas contra el emperador. Fue frecuentemente visitada por los papas, quienes pasaban allí parte del período estivo. La ciudad fue sede de cinco cónclaves y tres pontífices murieron en ella, dos de los cuales estuvieron muy relacionados con la primera historia de la Orden: Inocencio III (1216) y Gregorio IX (1241)."

URIBE, Fernando. Op. cit., p. 120.

${ }^{24}$ Cf. SABATIER, Paul. Op. cit., p. 107.

${ }^{25}$ Cf. MERLO, Grado Giovanni. Em nome de São Francisco. História dos Frades Menores e do franciscanismo até início do século XVI. Petrópolis: Vozes, 2005, p. 19.
} 
se um penitente; podemos afirmar somente que este homem de penitência não tivesse um conteúdo e uma normativa bem clara quando escolheu ser um penitente. Diferentemente da pobreza voluntária, a pobreza não voluntária era mal vista na sociedade medieval. Por isso, a atitude de aproximar-se dos marginalizados de todo contato humano daquela sociedade tinha um significado maior. Foi por meio do leproso que vivia isolado de tudo e de todos, quer fosse em grupo quer como indivíduo, que Francisco decidiu ser penitente, como nos recorda Falbel ${ }^{26}$.

Segundo os textos hagiográficos, à Igreja de São Damião ${ }^{27}$ foi atribuída uma experiência mística de Francisco, que teria ouvido uma voz vinda do crucifixo da igreja dizendo: "Francisco, não vês que minha casa está destruída? Vai e repara-a", entendida no sentido literal porque o edifício estava em ruínas. Provavelmente tratou-se de reparações pequenas. No ano de 1212 , esta igreja foi dada a Clara e as suas irmãs pelo bispo Guido. À Praça de São Rufino ${ }^{28}$ é atribuido o episódio em que Pedro Bernardone recorreu ao bispo da cidade, admoestou Francisco a devolver o dinheiro do pai e Francisco teria se despojado de suas vestes ${ }^{29}$.

${ }^{26}$ Cf. FALBEL, Nachman. Op. cit., p. 6.

${ }^{27}$ Sobre a Igreja de São Damião, Uribe explica que: "Las noticias sobre sus orígenes non son muy precisas. Hay quienes remontan la primera construcción a los años finales del siglo IX o a los primeros del $\mathrm{X}$. Se afirma que en el siglo $\mathrm{X}$ ya existían el ábside, el presbiterio y el tramo de la enfermería actual. Entre fines del siglo XI y a lo largo del siglo XII fue completada la iglesita con las dependencias del lado derecho (capilla, sacristía, sepulcro y coro) y a fines del mismo siglo XII fueron terminadas las dependencias de la planta superior. No es seguro que haya sido inicialmente una posesión benedictina. Lo que sí es cierto es que a comienzos del siglo XIII pertenecía a la diócesis de Asís y estaba bajo la administración del obispo."

URIBE, Fernando. Op. cit., pp. 91-93.

${ }^{28}$ No medievo foi a principal praça da cidade de Assis onde se localizava a igreja de São Rufino. Francisco teria sido batizado nesta igreja quando estava em processo de construção, hoje é a atual catedral de Assis. "La plaza de san Rufino se encuentra totalmente dominada por la fachada de la catedral, verdadero modelo del estilo románico."

URIBE, F. Op. cit., pp. 49-51.

${ }^{29}$ Para Merlo, o valor jurídico específico desses episódios estariam na passagem da renúncia a riqueza material do pai carnal para a riqueza espiritual do seguir Cristo nú, narração coerente com a tradição das crônicas de santidade, que segundo ele é fabulista e imaginária, na qual opõe o protagonista (Francisco) como personagem positivo ao antagonista como personagem negativo, personificado pelo pai (Pedro Bernardone), que põe no caminho do herói obstáculos que, servirão para provar a heroicidade/santidade do protagonista. Na verdade, não se sabe como Francisco renunciou aos bens e ao dinheiro da família para seguir uma vida religiosa. MERLO, Grado G. Op. cit., p. 25. Ver também: PÁSZTOR, Edith. "La fraternità di Francesco e Tommaso da Celano". In: I compagni di Francesco e la prima generazione minoritica. Atti del XIX Convegno internazionale, Assisi, 17-19 ottobre 1991. Spoleto: Centro Italiano di Studi sull'alto Medioevo, 1992, pp. 81-118. 
O Testamento fornece algumas "pistas" em relação à conversão e aos primeiros tempos de Francisco. Para a nossa pesquisa, entre outros motivos, os escritos de Francisco constituem um conjunto de condições principais e indispensáveis para investigarmos a respeito da formação do movimento franciscano da primeira geração menorita. Sendo assim, o Testamento de 1226 indubitavelmente ocupa um lugar privilegiado, porque é o único escrito que aparece como uma autobiografia, um relato, uma apresentação e um sumário de sua experiência global, da "conversão à iminência da morte". Temos sucintamente a consciência do itinerário e da obra de Francisco.

O Testamentum beati Francisci (testamento de São Francisco) e o Testamentum Senis Factum (testamento de Sena) podem ser colocados como parte do debate da pobreza da Ordem dos Frades menores. Ambos pertencem a um tipo de gênero retórico descrito no próprio texto; consideramos aqui como um texto de final de vida importante para a movimento franciscano, principalmente, para os "resistentes", as intervenções da Igreja Romana na Ordem a partir da segunda geração e não devem se unir ao conjunto de documentos da Ultima voluntas Sanctae Clarae scripta (Última vontade escrita a Santa Clara), escrito no fim de setembro de 1226, composto por três frases endereçadas às "irmãs pobres", no qual Francisco as convida a perseverarem na santíssima pobreza sem nunca dela se afastarem.

Para o Frei Martino Conti ${ }^{30}$, esses dois testamentos não fazem parte dos textos legislativos, porque seriam um "discurso de adeus ou despedida"; compõem-se de recordações, de exortações, de admoestações que se concluem com uma benção. Na verdade, sabemos que Martino Conti prefere seguir a linha da bula Quo Elongati de 1230 e recusa-se a colocar o Testamento de 1226 como um texto normativo a fim de evitar o debate RegraTestamento, seguindo a linha do frade alemão Kajetan Esser. Seguidores das diretrizes da bula Quo Elongati de Gregório IX, para ambos a pendência jurídica em torno do Testamento foi um assunto resolvido e não haveria motivo para retomar a discussão, argumentação que não se sustenta, tendo em vista a perpetuação da questão Regra-Testamento nos séculos XIII e XIV. As

${ }^{30}$ CONTI, Martino. Estudos e pesquisas sobre o franciscanismo das Origens. Petrópolis: Vozes, 2004, p. 284. 
constituições papais promulgadas revelam a permanência da discussão, tema que desenvolvemos no capítulo dois desta dissertação.

A crítica moderna atribui a autoria do Testamento à Francisco, devido ao pensamento, estilo e termos usados. Não temos conhecimento concreto de que alguém ajudou a redigir ou a complementar o texto. No entanto, o título Testamentum beati Francisci ${ }^{31}$ foi transmitido pelo códice 338 da Biblioteca Comunal de Assis no século XIII e dado em virtude do termo presente no próprio texto "et meum testamentum", que de alguma maneira caracteriza a sua natureza, discurso retórico e finalidade. Segundo os postulados de André Vauchez "a palavra 'testamento' aparece uma única vez, mas seu autor define o significado de maneira que reporta a três expressões: recordação, admoestação e exortação; [...] O Testamentum visaria sobretudo às indicações internas da Ordem dos Menores e denunciaria um certo desvio que poderia ameaçar as intuições essenciais daquele que a havia fundado."32. Provavelmente o Testamento foi redigido no fim do verão ou no início de outono de 1226, quando Frei Francisco estava bastante doente, quase cego e com a idade de aproximadamente quarenta e cinco anos. Em termos de conteúdo, o Testamentum pode ser dividido em quatro partes: a conversão; a fé na eucaristia e na palavra de Deus; como se vivia nos primeiros tempos; como Francisco exige que tal forma de vida jamais mude, fundado solidamente no princípio de pobreza absoluta e tendo como modelo somente o Evangelho ou a Imitatio Christi.

Dans une première partie, il parle de lui-même comme il ne l'a jamais fait et retrace son itinéraire spirituel depuis son $<<$ retournement $>>$ et as conversion à l'Évangile. [...] L'évocation par François de as conversion et de la fraternité des premiers temps répond bien, par ailleurs, au désir qu'il exprima dans les dernières années de sa vie de revenir à I'humilité des commencements: servir les lépreux, travailler de ses mains et ne recourir à l'aumône qu'em cas de nécessité, obéir sans hésitation ni murmure à ses supérieurs, annoncer la paix, non pour idéaliser ce passé mais pour tenter de lui redonner une actualité qu'il était en train de perdre. [...] Dans une seconde partie, il admoneste ses frères en leur demandant de ne pas trahir l'idéal primitif dont il rappelle les éléments essentiels: fidélité à l'Église romaine parce qu'elle perpétue la réalité de l'Incarnation à travers les édifices religieux, les vases sacrés et surtout l'eucharistie et rend ainsi

${ }^{31}$ Cf. CONTI, Martino. "Testamento de São Francisco". IN: CAROLI, Ernesto (org.) Dicionário franciscano. Petrópolis: Vozes, 1999, p.741.

${ }^{32}$ VAUCHEZ, André. François d'Assise. Entre histoire et mémoire. Paris: Fayard, 2009, pp. 208-209. 
sensible la présence de Dieu au milieu des hommes; soumission aux prêtres dont la raison d'être est de consacrer le corps du Christ et qu'il faut respecter, quelles que soient leur indignité et leurs faiblesses. ${ }^{33}$.

Para Fernando Uribe, devemos levar em conta que a descrição do Testamento foi ditada por Francisco dezessete anos depois da aprovação oral pontíficia de Honório III (1216-1227) e o seu conteúdo pode estar contaminado pela sua experiência posterior ${ }^{34}$. Outro aspecto importante a ressaltar refere-se à narrativa linear/plana do texto com ausência de tensões ou conflitos na Ordem. Francisco escreveu estas últimas palavras com o objetivo de deixar uma mensagem de compreensão imediata para os seus frades, conforme vemos no trecho abaixo.

\begin{abstract}
Et non dicant fratres: Haec est alia regula, quia haec est recordatio, admonitio, exhortatio et meum testamentum, quod ego frater Franciscus parvulus facio vobis fratribus meis benedictis propter hoc, ut regulam, quam Domino promisimus, melius catholice observemus. Et generalis minister et omnes alii ministri et custodes per obedientiam teneantur, in istis verbis non addere vel minuere. ${ }^{35}$
\end{abstract}

A seguir verificaremos que, para a historiografia, o Testamento aparece como uma integração explicativa e até mesmo normativa da Regra conforme ressalta Merlo ${ }^{36}$. Contudo, o Testamento de Sena consiste de meia dúzia de frases, não fornecendo informações significativas a respeito da vida de Francisco. Provavelmente foi escrito em abril de 1226, seis meses antes da morte de Francisco. O problema é que os padres não o colocaram entre os escritos de Francisco. A mensagem do Testamento de Sena é curta, composta por cinco frases, o conteúdo é breve: "os frades devem se amar entre si como ele os amou, devem sempre se amar e observar a Santa Pobreza, devem ser sempre súditos dos prelados e clérigos da santa mãe Igreja Católica ${ }^{37}$. Devido às considerações acima mencionadas, usaremos somente o Testamento de Francisco, que fornece maiores informações e também pela discussão deste registro pelos frades das primeiras gerações. Apesar de os elementos

\footnotetext{
${ }^{33}$ VAUCHEZ, André. Op. cit., pp. 209-210.

${ }^{34}$ URIBE, Fernando. "La 'pre-historia' de la Regla Franciscana". In: LAVILLA (org.), Miguel Ángel. Selecciones de Franciscanismo. Valencia: 2010, 115, volume XXXIX, fasc. 1, p. 32.

35 Testamentum, 34-36. MENESTÒ, Enrico e BRUFANI, Stefano. Fontes franciscani. Assis: Edizione Porziuncola, 1995, p. 231.

${ }^{36}$ MERLO, Grado Giovanni. Op. cit., p. 20.

${ }^{37}$ Cf. CONTI, Martino. Op. cit., p.747.
} 
autobiográficos serem bastante escassos do ponto de vista dos fatos e dos acontecimentos, são bastante sólidas as afirmações de princípio e profissão de fé de Frei Francisco. Sobre a sua conversão, temos um testemunho inexpressivo e sintético, mas muito significativo como fonte de primeira mão para reconstruir os momentos culminantes da vida de Francisco e de sua experiência evangélica junto com seus primeiros companheiros. Em primeiro lugar, é importante analisarmos o seu conteúdo para melhor entendimento das tensões imbricadas a respeito da pobreza franciscana.

Dominus ita dedit mihi fratri Francisco incipere faciendi poenitentiam: quia cum essem in peccatis nimis mihi videbatur amarum videre leprosos. Et ipse Dominus conduxit me inter illos et feci misericordiam cum illis. Et recedente me ab ipsis, id quod videbatur mihi amarum, conversum fuit mihi in dulcedinem animi et corporis; et postea parum steti et exivi de saeculo. ${ }^{38}$

O trecho acima marcou em poucas linhas o momento decisivo, a escolha espiritual que culminou numa reviravolta de valores, da conversio, com a antítese amargo-doce e com o fato que determinou esta mudança: o encontro com os leprosos. Conforme o Testamentum acima mencionado, o itinerário de conversão do pobre de Assis foi através da figura do leproso. Assim, consideramos que o estado físico dos leprosos suscitava "amargura", Se olharmos com os olhos dos desvalores da sociedade medieval, a pobreza não voluntária nos transmite negatividade; o leproso é um elemento estranho que transmite tristeza e pessimismo em relação à condição humana. Já a pobreza voluntária expressada pelo "converter-nos" a Deus levaria o homem a valores positivos, superiores, elevados. Com isso, o "fazer penitência" seria o início de uma caminhada para a positividade e alegria. Francisco teria encontrado um sentido para sua opção penitencial, longe dos julgamentos e juízos de valores correntes daquela sociedade. Contudo, as origens deste movimento penitencial encontravam-se radicadas na piedade laica que teria florescido, segundo Francis Rapp, no ambiente urbano, favorecido pelas modificações sócioeconômicas e religiosas produzidas nos séculos XII e XIII, inseridas no contexto da desagregação do sistema feudal e dos laços de parentela e com o

${ }^{38}$ Testamentum, 1-3. IDEM, ibidem, p. 227. 
advento da pequena propriedade de exploração familiar, que fracionou o trabalho, reduzindo-o ao quadro familiar ${ }^{39}$.

A fraternitas franciscana surgiu dentro de um contexto que se projetava numa necessidade crescente de projeção social, numa assembléia que reunisse a comunidade. Neste momento, no campo, assistiu-se a uma intensificação e aprofundamento do significado das paróquias, gerando uma nova religiosidade, que iria progressivamente adquirir autenticidade popular, em especial quando da junção entre esses elementos e aqueles resultantes do florescimento urbano - a cidade, ambiente propício à emergência do individualismo social e econômico, também representava uma espécie de obstáculo à continuidade dos laços clientelistas e da solidariedade vertical observados nas villae. Estima-se que em Paris, entre 1080 e 1290, foram criadas vinte e quatro paróquias. Segundo os postulados de Francis Rapp, em regra geral o fenômeno referendava os esforços da lgreja em prol do ajustamento de suas instituições à realidade que ela encontrava nas aglomerações em pleno desenvolvimento ${ }^{40}$.

Como bem observa Francis Rapp, os séculos posteriores assistiram a um aumento substancial do número de confrarias. Entretanto, a gênese dessas agremiações não estava, num primeiro momento, vinculada à atuação da autoridade eclesiástica, mas sim fortemente relacionada às necessidades endógenas da sociedade laica, que pugnava pela proximidade da religião. Assim, uma das formas de compensação para essa nova carência que se fazia sentir no ambiente urbano foram as associações, fundadas sobre bases profissionais e sobretudo religiosas, forjando a nova comunidade, dessa maneira "ressocializada". Tais elementos, associados às liberdades características do ambiente citadino, originariam confrarias que dariam origem tanto a baluartes de santidade, como Francisco de Assis, quanto a severas imputações de heresia. É comum, inclusive, detectarem-se envolvimentos em heresia unicamente por força do sentimento de pertença ao grupo religioso,

\footnotetext{
${ }^{39}$ RAPP, Francis. L'Église et la vie religieuse en occident a la fin du Moyen Age. Paris: Presses Universitaires de France,1971, pp. 122 e 123.

${ }^{40}$ IDEM, Ibidem.
} 
com o qual se podiam partilhar interesses comuns, os quais se sobrepunham à própria crença obstinada a que, eventualmente, alguns eram conduzidos ${ }^{41}$.

Deste modo, os impulsos religiosos apontavam para os estímulos provenientes da própria reforma monástica, entre os séculos XI e XII, marcada, entre outros aspectos, pela difusão da fé por intermédio da pregação dos cistercienses, o que transformaria Bernardo de Claraval (1090-1153) em um dos baluartes da evangelização reformista. A partir do conhecimento, ainda que difuso, embora mais aprofundado que outrora de elementos de doutrina e de prática religiosa, os habitantes da cidade (principalmente) passaram a reclamar os serviços da missa e a rede paroquial urbana acabou por adensar-se.

Para Stanislao da Campagnola é significativa a constatação de que a ideia de uma "imitatio Christi" com base na pobreza seja fruto do fervor evangélico que havia precedido a experiência de Francisco de Assis. Logo, todo um arco de um século o acompanhava no seu desenvolvimento, porém isto não significa que a figura do pobre de Assis perdeu a sua importância nítida e distinta na sucessão e no desenvolvimento dos problemas pauperísticos. Ao contrário, porque só com Francisco é que se chegou a uma perfeita clareza e consciência de que a pobreza era um elemento essencial da "Imitatio Christi" que, seja com um pouco de cada doutrina teológica e de cada impostação canonística, veio a legitimar a conturbante função histórica de um pobre "voluntário" como membro de uma Igreja rica, em um contexto perfeitamente ortodoxo, contribuindo de forma a minimizar, mas não sem contrastes, os fermentos de oposições e de crítica religiosa e social. ${ }^{42}$.

Assim, nesta sociedade em que todos têm o seu estatuto preciso, Francisco preferiu estar entre aqueles que não tinham estatuto privilegiado segundo o Testamento. Para Desbonnets, com um tom evocativo e estilo descritivo, a expressão "cum essem in peccatis" de Francisco revelou uma reflexão em relação a sua vida, da sua infância à maturidade. Foi tudo condenado, um sinal de mudança assinalado por uma indicação providencial. Todavia, podemos aferir que pecados não significariam culpas específicas,

\footnotetext{
41 MAGALHÃES, Ana Paula Tavares. Entre a ermida e a cidade: dilemas da Ordem Franciscana entre os séculos XIII e XIV. S/d, pp. 1-2.

42 CAMPAGNOLA, Stanislao da. La povertà nelle "Regulae" di Francesco d'Assisi. In: La povertà del secolo XII e Francesco d'Assisi. Assis: Atti del II Convegno Internazionale, 1975, p. 222.
} 
mas, ao contrário, uma vida ligada a prazeres e divertimentos do século e esquecida de Cristo, não penitente. Já o "exivi de saeculo" era uma expressão técnica que denotava deixar o estado de vida anterior e abraçar uma das formas do estado religioso: o eremitismo ou o monaquismo ${ }^{43}$.

Além disso, a gênese da palavra penitência é de origem grega "metanóia", que adquiriu um significado específico no movimento Franciscano do século XIII, palavra presente no Testamento definitivo. No sentido bíblico, o termo metanóia foi traduzido da vulgata como penitência ou conversão. Porém, originalmente na língua grega, metanóia exprime uma mudança de atitude ou persuasão que corrige algo. Na tradição cristã, a palavra conversão significou "voltar a Deus". No Novo Testamento, metanoeite era o mesmo que arrependei-vos, convertei-vos, fazei penitência. (Mt 3,2). Sendo assim, o conceito penitência estaria associado à concepção de obediência como uma resposta do homem ao chamamento divino para uma nova vida ${ }^{44}$. Neste sentido, Francisco converteu-se em 1206, seguindo o chamamento divino, iniciando uma pregação penitencial conforme descrito no seu Testamentum. Neste documento, fazer penitência seria caminhar no sentido de valores positivos da pobreza voluntária, distanciando-se da negatitividade a partir do fazer misericórdia com os leprosos, condição sine qua non de estar no meio deles para se projetar para novas dimensões existenciais. Sabemos que toda a vida e a visão de mundo do homem medieval girava em torno da presença do pecado, por isso é significativo o uso desta palavra ${ }^{45}$. Para Francisco, a penitência não se fundamentaria na vontade própria, não seria a prestação do homem para si mesmo, mas uma dádiva e graça concedidas, seria o atender a um chamamento divino para uma pobreza voluntária prática.

Deste modo, o "facere poenitentiam" consistiria num conceito central para o começo de uma vida penitente no medievo, na qual se tratava de uma ruptura com o 'mundo' e a conversão total para com Deus, uma atitude fundamental na vida de todos que queriam estar "arrependidos" no período. Neste caso, o homem penitente rompia com tudo aquilo que era agradável a

\footnotetext{
${ }^{43}$ Cf. DESBONNETS, Theophile. Op. cit., p. 26.

${ }^{44}$ Cf. PAZZELLI, Raffaelle. "Penitência, mortificação". In: CAROLI, Ernesto (Org.). Dicionário Franciscano. Petrópolis: Vozes, 1999, p. 551.

${ }^{45}$ Cf. CASAGRANDE, Carla \& VECCHIO, Silvana. "Pecado". In: LE GOFF, Jacques e SCHIMIDT, Jean-Claude. Dicionário Temático do Ocidente Medieval. Coord. Da trad. Hilário Franco Jr. Bauru: EDUSC; São Paulo: Imprensa Oficial do Estado, 2002, 2 v., p. 337.
} 
ele mesmo, ao seu próprio 'eu', uma ruptura com as coisas mundanas para o seguir Cristo, para o "exivi da saeculo". Tratar-se-ia de uma conversão a um cristianismo integral e reformado ${ }^{46}$, concepções correntes na religiosidade popular de Assis do início do século XIII.

No Testamento de Francisco, o pecado talvez houvesse sido colocado como uma condição ou lepra da alma, uma designação corrente na espiritualidade do tempo: os verdadeiros doentes eram os da alma e não os do corpo, por isso causava horror aquela moral contra a pobreza não voluntária que tinha repugnância dos leprosos ${ }^{47}$. Francisco rejeitou os valores correntes da sociedade assisiense e de seus critérios de julgamento, encontrando um sentido em sua opção, através da pobreza voluntária, da convivência com os leprosos e com a leitura do Evangelho. Efetivamente os leprosos eram excluídos da sociedade, eram marginalizados e colocados no banimento, circundados pelo horror que Francisco confessa no seu Testamento ${ }^{48}$.

De acordo com as hagiografias de Celano e Boaventura, o momento mais importante da conversão teria ocorrido durante a realização de uma missa na igreja da Porciúncula ${ }^{49}$, Francisco e companheiros ouviram as palavras do Evangelho de São Mateus sobre viver sem provisões. Este viver sem nada de próprio tem origem bíblica, uma resignificação do movimento Franciscano da primeira geração menorita do seguinte trecho "Se queres ser perfeito, vai, vende o que possuis e dá aos pobres, e terás um tesouro nos céus. Depois, vem e segue-me." (Mt 19, 21). Se o episódio de conversão foi desta forma ou

${ }^{46}$ ESSER, Kajetan. As origens e espírito primitivo da Ordem Franciscana. Petrópolis: Vozes, 1972, pp. 225-226.

${ }^{47}$ Devido à endêmica falta de higiene, causada pela desnutrição ou subalimentação, muitas doenças de pele, acabavam sendo confundidas com a lepra, o que aumentava o número quantitativo de doentes.

${ }^{48}$ MANSELLI, Raoul. Op. cit., pp. 42-43.

49 "En el año 1054 ya se encuentra un documento que habla del lugar donde se halla la capilla, pero es necesario esperar hasta la mitad del siglo XII para encontrar el primer documento que se refiera a la capilla como tal. Se trata de una bula del papa Eugenio III (1145-1153), en donde aparece la capilla enumerada entre las posesiones del monasterio de San Benito del monte Subasio. [...] Los documentos la identifican como <<santa María de la Porciúncula >> por sus exiguas dimensiones (<<porcioncita $>>)$ y al lugar circundante lo llaman el $<<$ cerretto della Porziuncola >> para referirse al bosque que estaba cerca de ella."

URIBE, F. Op. cit., pp. 78 e 79.

Ver também: "Santa Maria degli Angeli è una costruzione semplicissima, in pietra bianca del Subasio, posta a circa tre $\mathrm{Km}$. da Assisi. L'edificio, lungo nove metri e largo quattro, in età medievale sorgeva in aperta campagna, lungo la via Perusina, antica strada di collegamento tra la via Flaminia e Perugia". SENSI, Mario. Il perdono di Assisi. Assisi: edizioni porziuncola, 2002, p. 1. 
não, o trecho bíblico acima mencionado serviu de base para a redação da Regra Apostólica nos Capítulos II e VI: “... digam-Ihes a palavra do santo Evangelho que vão e vendam todos os seus bens e procurem distribuí-los aos pobres (cf. Mt 19,21)" e "Os irmãos não se apropriem de nada, nem de casa, nem de lugar, nem de coisa alguma. E como peregrinos e forasteiros (cf. $1 \mathrm{Pd}$ 2,11) neste mundo, servindo ao Senhor em pobreza e humildade, peçam esmola com confiança; e não devem envergonhar-se, porque o Senhor se fez (cf. 2 Cor 8,9) pobre por nós neste mundo. Esta é aquela sublimidade da altíssima pobreza (cf. 2 Cor 8,2) que vos constituiu, meus irmãos caríssimos, herdeiros e reis do reino dos céus, vos fez pobres (cf. Tg 2,5) de coisas, vos elevou em virtudes" ${ }^{50}$. A seleção bíblica desses trechos acima mencionados não foi uma descoberta do movimento Franciscano; outros grupos religiosos em diferentes épocas já colocavam a pobreza como centralidade e utilizavam inclusive os mesmos excertos, a resignificação dos trechos evangélicos somados aos elementos sociais - ambiente citadino, piedade laica, reforma monástica, necessidades endógenas da sociedade - que mencionamos advindos do contexto histórico do século XIII consistem numa peculiaridade nova.

Em seu Testamento, como bem nos recorda Manselli ${ }^{51}$, Francisco revelou que não queria ser sacerdote ou monge, muito menos entrar em polêmicas com a hierarquia eclesiástica de seu tempo. Antes de relatar como alcançou o seu caminho, a sua forma vitae ou propositum vitae, Francisco esclareceu a necessidade de exprimir a sua devoção e respeito aos sacerdotes. A renúncia a qualquer crítica tem um significado maior, Francisco e seus primeiros companheiros obedeciam à Igreja e não entraram em conflito com ela em nenhum momento durante a formação do movimento Franciscano ou a construção da Norma. Conforme o Testamento, Francisco optou pela condição de penitente/marginalizado (pobre voluntário), respeitando com devoção os sacerdotes como observamos neste trecho abaixo.

${ }^{50}$ Cf. Bíblia de Jerusalém. São Paulo: Paulus, 2008, p. 1739; Regra bulada ,2, 6 e 6, 3-5. In: TEIXEIRA, Celso Márcio (org.). Fontes Franciscanas e Clarianas. Petrópolis: Vozes, $2^{\underline{a}}$ edição, 2008, pp. 158 e 161.

${ }^{51}$ MANSELLI, Raoul. Op. cit., p. 71-72. 
Postea Dominus dedit mihi et dat tantam fidem in sacerdotibus, qui vivunt secundum formam sanctae Ecclesiae Romanae propter ordinem ipsorum, quod si facerent mihi persecutionem, volo recurrere ad ipsos. Et si haberem tantam sapientiam, quantam Salomon habuit, et invenirem pauperculos sacerdotes huius saeculi, in parochiis, quibus morantur, nolo praedicare ultra voluntatem ipsorum. Et ipsos et omnes alios volo timere, amare et honorare, sicut meos dominos. Et nolo in ipsis considerare peccatum, quia Filium Dei discerno in ipsis, et domini mei sunt. Et propter hoc facio, quia nihil video corporaliter in hoc saeculo de ipso altissimo Filio Dei, nisi sanctissimum corpus et sanctissimum sanguinem suum, quod ipsi recipiunt et ipsi soli aliis ministrant. Et haec sanctissima mysteria super omnia volo honorari, venerari et in locis pretiosis collocari. Sanctissima nomina et verba eius scripta, ubicumque invenero in locis illicitis, volo colligere et rogo, quod colligantur et in loco honesto collocentur. Et omnes theologos et, qui ministrant sanctissima verba divina, debemus honorare et venerari, sicut qui ministrant nobis spiritum et vitam. ${ }^{52}$

Devido a sua posição de laico e conforme o excerto, Francisco respeitava e venerava os sacerdotes, não porque fossem mais cultos e sábios, mas pelo fato de serem sacerdotes, e, como tais, consagravam o corpo e o sangue de Cristo, reforçando aquilo que poderiamos chamar de cristocentrismo franciscano. No mesmo período, os franciscanos agiam de forma diferente dos cátaros, que também estavam presentes na Úmbria e no vale do Espoleto, do qual fazia parte a cidade de Assis, conhecidos como os desobedientes da ortodoxia e questionadores dos sacramentos da fé católica. A heresia cátara ${ }^{53}$ rejeitava o poder sacramental dos sacerdotes, mas o movimento era análogo aos franciscanos em relação à pobreza enquanto premissa.

Francisco, no trecho mencionado, contrapõe com respeito ao sacerdote, respeito ao corpo e ao sangue de Cristo presentes no sacramento eucarístico, rejeitava a posição cátara que considerava Cristo como um anjo, filho de um anjo, vindo à terra para revelar aos homens os seus pecados. Outra diferença em relação aos cátaros era a cruz, que era vista como maldita porque teria sido o instrumento para fazer sofrer e morrer aquele que viera para indicar o caminho da salvação, algo indigno da obra redentora de Deus. Francisco revelou que não queria ser nem monge, nem sacerdote e nem herege, mas submisso a todos, principalmente à Igreja Romana e que o

\footnotetext{
52 Testamentum, 6-13. Fontes Franciscani..., pp. 227 e 228.

${ }^{53}$ Para os cátaros, o encargo de Cristo foi uma simples missão num mundo satânico, sendo negadas a encarnação, a paixão e a ressureição. Para esta heresia, o homem não foi criado à imagem de Deus, mas pelo demônio. Por isso, o ódio dos cátaros pela cruz e pelo sinal da cruz que se relacionam aos sofrimentos de Cristo e o ligam à matéria impura. NACHMAN, Falbel. Heresias medievais. São Paulo: Perspectiva, 1976, p. 54.
} 
"Senhor me deu e me dá fé nos sacerdotes". A cruz virava um símbolo em formato de "tau", representando a salvação através da cruz mediante a penitência ${ }^{54}$. Como veremos mais adiante, a obediência à Igreja por Francisco e companheiros foi essencial para a formação e o crescimento do movimento.

Francisco estava decidido em sua penitência e, tendo chegado ao Evangelho, optando pela pobreza voluntária, embora sem perder nada da sua qualidade e tipicidade originárias da escolha da experiência entre os marginalizados. Ele vestiu o hábito de eremita que logo abandonou para assumir outro, ainda mais pobre. Para Manselli ${ }^{55}$, um pano rude com o qual se cobria e, no lugar de uma correia, uma corda, abandonando o bastão e os calçados, conforme um literalismo que era característico dos movimentos leigos populares penitenciais da Úmbria. O Testamento nos informa que "começou por inspiração divina" a anunciar a perfeição evangélica e a pregar a penitência com simplicidade; falava em público com eficácia; convidava a todos a perseverarem na penitência e na verdadeira fé, único caminho para a salvação. Logo a situação começou a mudar de tal modo que alguns decidiram seguir o exemplo dele e juntar-se a ele na vida e no hábito. Não nos passa despercebido ser essa uma passagem significativa para entendermos a perspectiva da perfeição evangélica, e, em particular, da importância do "fazer penitência" no horizonte religioso e salvífico de Francisco. Todos seriam iguais no plano da salvação; a única linha de demarcação entre os que se salvariam e os que não se salvariam consistiria no fare penitenza ${ }^{56}$.

A leitura do Testamento é necessária para tentarmos esclarecer a primitiva forma vitae que Francisco fez "escrever em poucas palavras" e que logo apresentou ao papa para a sua aprovação, um caminho elucidativo para examinar os vestígios destes primeiros tempos anterior à redação das Regras de 1221 e 1223. Apesar de gêneros retóricos distintos, em termos de conteúdo,

\footnotetext{
${ }^{54}$ Há duas hipóteses para a entrada do símbolo Tau no movimento Franciscano, a primeira seria porque sob a influência de um hospital de leprosos mantido pelos irmãos hospitaleiros de Santo Antão, eremita que tinha como distintivo o Tau no seu hábito e bastão encimado por um Tau, teriam influenciado Francisco. A segunda hipótese é devido a segunda parte do discurso de Inocêncio III no IV Concílio de Latrão ter assinalado com um Tau a fronte dos homens, o papa teria também explicado a simbologia da letra, associando-a a cruz. VORREUX, Damien. "Tau". In: CAROLI, Ernesto. Dicionário Franciscano. Petrópolis: Vozes, 1999, pp. 724-727.

${ }^{55}$ MANSELLI, Raoul. Op. cit., pp.75-76.

${ }^{56}$ Cf. CASAGRANDE, Giovanna. "Un Ordine per i laici. Penitenza e Penitenti nel Duecento." In: MERLO, Grado Giovanni et al. Francesco d'Assisi e il primo secolo di storia francescana. Torino: Einaudi, 1997, p. 240.
} 
há pelo menos sete pontos do Testamento que estão de acordo com a Regra bulada segundo Desbonnets ${ }^{57}$. Ademais, devido às recomendações do texto: "Et in omnibus capitulis quae faciunt, quando legunt regulam, legant et ista verba"58, o Testamento passou a ser lido por alguns frades como um complemento à normativa.

Os sete pontos localizam-se nos versículos 16-23, quando Francisco recorda aos frades o essencial do que tinha prometido, e remontam à época dos primeiros tempos, mencionando a desapropriação como condição prévia, a forma pobre de se vestir, a oração em comum, a forma 'menor' de ser e estar na sociedade, o trabalho como forma de ocupação e de subsistência, a esmola como meio alternativo de subsistência e o anúncio da paz com conteúdo essencial da evangelização.

\begin{abstract}
Et illi qui veniebant ad recipiendam vitam, omnia quae habere poterant (Tob 1,3), dabant pauperibus; et erant contenti tunica una, intus et foris repeciata, cum cingulo et braccis. Et nolebamus plus habere. Officium dicebamus clerici secundum alios clericos, laici dicebant: Pater noster (Mat 6,9-13); et satis libenter manebamus in ecclesiis. Et eramus idiotae et subditi omnibus. Et ego manibus meis laborabam (cfr. Act 20,34), et volo laborare; et omnes alli fratres firmiter volo, quod laborent de laboritio, quod pertinet ad honestatem. Qui nesciunt, discant, non propter cupiditatem recipiendi pretium laboris, sed propter exemplum et ad repellendam otiositatem. Et quando non daretur nobis pretium laboris, recurramus ad mensam Domini, petendo eleemosynam ostiatim. Salutationem mihi Dominus revelavit, ut diceremus: Dominus ded tibi pacem (cfr. 2 The 3,16$).{ }^{59}$
\end{abstract}

Esses sete elementos principais seriam vestígios da "proto-Regra" de 1210 concentrados nos versículos 16-23 do Testamento. Nas Regras também aparecem os setes pontos mencionados que foram agregados junto com os textos inspiradores do Evangelho. Para precisar o conteúdo da forma de vida que guiou a primitiva fraternidade menorita durante os primeiros anos de sua experiência de vida evangélica, faz-se necessário adentrar ainda mais ao conteúdo do Testamento, fonte de primeira mão para reconstruir muitos dos momentos culminantes da vida de Francisco e de sua experiência evangélica junto com os seus primeiros companheiros.

\footnotetext{
${ }^{57}$ Citação feita por URIBE, Fernando. "La 'pre-historia' de la Regla Franciscana". In: LAVILLA (org.), Miguel Ángel. Selecciones de Franciscanismo. Valencia: 2010, 115, volume XXXIX, fasc. 1 , p. 32.

${ }^{58}$ Testamentum, 37. Fontes Franciscani... , p. 231.

${ }^{59}$ Testamentum, 16-23. Fontes Franciscani... , pp. 228-229.
} 


\subsection{A formação do movimento Franciscano e a primeira geração menorita}

Como bem coloca o frei americano marxista David Flood ${ }^{60}$, a história do movimento Franciscano foi condição da história de Frei Francisco. Temos primeiro o movimento, depois Francisco, no entanto, o movimento Ihe deveu tudo, de uma certa maneira, porque sem Francisco não haveria movimento algum. Contudo, podemos fazer a afirmação contrária, Francisco tudo deveu ao movimento e sem o movimento não haveria o Francisco que realmente existiu ou conhecemos. É a partir da entrada de companheiros que se inicia o movimento Franciscano. De início era uma fraternitas com meia dúzia de penitentes, depois evoluiu para uma nova Ordo clericorum. Por isso, utilizamos ao longo da dissertação o termo movimento Franciscano, porque entendemos que se trata de um movimento coletivo a construção da norma e não como parte da individualidade de Francisco.

É imprescindível compreender que as palavras fraternitas e Ordo não são sinônimos e constituem palavras-chave da antropologia e da sociologia desta época. Fraternitas remete à existência de relações recíprocas de cada um em relação a cada um, um alter alterius, difere bastante do que hoje chamamos de fraternidade; no século XIII implica consanguinidade espiritual de batizados com Cristo para um mesmo grupo. Segundo Desbonnets, a melhor definição de fraternitas seria de G. Le Bras: "A fraternitas é essencialmente um grupo de iguais, associados para uma obra comum, que pode ser religiosa ou profana" e de Michaud-Quantin: "A confraria medieval manifesta-se assim como um grupo, cujos membros proclamam e procuram realizar entre si os laços da fraternidade que unem os cristãos, e também encontram, na sua união, uma resposta à busca de uma solidariedade de base que os ajuda a escapar de sua condição de isolados". ${ }^{61}$ Por outro lado a palavra Ordo revelaria também muitos significados, mas o campo semântico que ela cobre é bem mais unificado. Dá um sentido de ordem ${ }^{62}$, pode designar modo de viver ou um

${ }^{60}$ Cf. FLOOD, David. Frei Francisco e o Movimento Franciscano. Petrópolis: Vozes, 1986, p. 65.

${ }^{61}$ DESBONNETS, T. Op. cit., pp. 75-76.

62 Atentos ao modelo de Ordem religiosa, sem perder de vista que: "O ordo clericalis, possuindo com exclusividade o 'sagrado' (quer dizer, o que se refere diretamente ao culto e, 
conjunto de mosteiros que seguiam a mesma regra ou de lugar dos monges no coro. Para John Moorman ${ }^{63}$, a fraternitas é a palavra mais apropriada para a primeira fase do movimento Franciscano porque era um grupo de homens que não tinham nenhuma organização e nenhuma Regra, a não ser a seleção de trechos do Novo Testamento como guia.

Para Desbonnets, a evocação das lembranças dos primeiros tempos no Testamento mostraria o encontro da "intuição com a instituição"64. Os versículos bíblicos: (Mt 19:21), (Mt 16:24) e (Mt 6: 8-9 e Lc 9,3) ${ }^{65}$ serviram de base para o que os historiadores classificam de proto-Regra, que foi submetida à confirmação de Inocêncio III em 1209 ou 1210, como já mencionamos. Desse modo, a proto-Regra é citada no Testamento: "E eu o fiz escrever em poucas palavras e simplesmente, e o senhor papa confirmou para mim", o papa mencionado é Inocêncio III e as poucas palavras seriam a forma vitae ou uma forma de vida que não corresponde ao sentido legislativo de regra.

O texto original da proto-Regra foi perdido. Sabemos através da historiografia que era composta por simples frases evangélicas. O texto da primeira "Regra" foi escrito para seus primeiros companheiros, era curta e simples, compunha-se essencialmente de algumas passagens do Evangelho, de modo singelo, não comportava nenhum aspecto jurídico, fruto de um projeto ainda muito confuso com uma fórmula que o exprimia ao mesmo tempo que o justificava. Nas palavras de Omer Englebert, a proto-Regra colocava aos irmãos um gênero de vida partilhado pelo Cristo aos seus apostólos, os primeiros socii deveriam praticar integralmente o Evangelho. A não tão novidade de Francisco estava no fato de o Evangelho ser tomado ao pé da letra como fundamento de estado religioso. Já para Le Goff, a "Regra" de 1209/1210 era um simples formulário composto de algumas frases evangélicas de forma a orientar a vida apostólica dos frades. Porém, para Paul Sabatier, a

mais amplamente, todos os bens que dependem do altar), controla a totalidade do poder de mediação sacramental. Os leigos têm somente acesso indireto ao sagrado". IOGNA-PRAT, Dominique. "Ordem". In: LE GOFF, Jacques e SCHIMIDT, Jean-Claude. Dicionário Temático do Ocidente Medieval. Coord. Da trad. Hilário Franco Jr. Bauru: EDUSC; São Paulo: Imprensa Oficial do Estado, 2002, p. 311.

${ }_{63}$ MOORMAN, John. L'espanzione Francescana dal 1216 al 1226. In: Francesco d'Assisi e francescanesimo dal 1216 al 1226. Spoleto: Atti della Società Internazionale di studi francescani, 1977, p. 268.

${ }^{64}$ Cf. DESBONNETS, Theophile. Op. cit., p. 27.

${ }^{65}$ Cf. FALBEL, Nachman. Os Espirituais Franciscanos, São Paulo: EDUSP, FAPESP, Perspectiva, 1995, p. 8. 
"Regula" era muito simples e composta sobretudo por trechos do Evangelho; eram versículos que Francisco havia lido aos seus primeiros companheiros, com acréscimo de alguns preceitos a respeito do trabalho manual e das ocupações dos novos frades ${ }^{66}$. E André Vauchez sintetiza: "Francisco tinha feito aprovar, em 1209, por Inocêncio III, um texto que parece ter sido constituido por uma série de perícopes evangélicas postas lado a lado. Não existia uma regra mas um simples programa de vida (propositum), destituído de valor jurídico porque não havia sido promulgado pela Cúria pontifícia num documento oficial munido de uma Carta (em latim medieval: bulla, do qual deriva bula em português e "bulle" em francês)" ${ }^{\text {"67 }}$. Em suma, era um código de vida espiritual que mostrava como Francisco e os primeiros irmãos desejavam viver. Talvez se tivéssemos este pequeno texto, a vida de Francisco de Assis e a imagem que temos dela seriam ainda mais completas.

Antes de retornarmos ao Testamento, vale lembrar que regra vem do latim regula e significa um conjunto de normas de uma comunidade religiosa. É um documento jurídico que regulamenta a vida dos frades, revela as regras de conduta específica deles e o estatuto desta ordem religiosa, mas podemos simplificar como norma ou regulamento. A Regra Franciscana de 1223 é também conhecida como Regra apostólica ou Apostolorum devido ao seu modelo peculiar. Está fundamentada nos quatro princípios básicos da primeira comunidade cristã - comunhão fraterna, fração do pão, oração e ensinamento - , por isso possui um caráter diferente das regras anteriores da tradição monástica da Europa medieval latina, das regras eremíticas (São Pacômio), monástica (São Bento) e canonical (Santo Agostinho).

Esta regra composta no século XIII (ano de 1223) foi o resultado de uma experiência de vida vivida por Francisco de Assis e seus primeiros companheiros, caracterizada basicamente pelos elementos do ideal de pobreza, da imitação da vida de Cristo (cristocentrismo), da pregação itinerante (non stabilitas locii) e da mendicância. Esta Regra, tida como normativa fundamental, foi gestada aos poucos durante anos em muitos Capítulos dos

\footnotetext{
${ }^{66}$ Cf. ENGLEBERT, Omer. Vie de Saint François d'Assise. Paris: Albin Michel, 1982, p. 96-98; LE GOFF, Jacques. Op. cit., p.71; SABATIER, Paul. Op. cit., 159-160.

${ }^{67}$ VAUCHEZ, André. François D’Assise. Entre histoire et mémoire. Paris: Fayard, 2009, p. 168.
} 
frades. Sabemos que a regra não foi escrita somente pelo Frei Francisco, mas é-Ihe atribuída a autoria principal.

Assim, partimos do pressuposto de que o gênero 'regra' consiste, de forma geral, de um recurso retoricamente elaborado e utilizado em larga escala pela instituição eclesiástica para regulamentar as Ordens Religiosas regulares. A Regra bulada enquanto gênero retórico situa-se no contexto das outras Regras monásticas e das Constituições de outros institutos religiosos, realiza a função de "lei constitutiva" da Ordem Franciscana. É o resultado da autenticação dada pela Igreja (elemento jurídico) mais o elemento espiritual (representado pela experiência de vida da primeira geração menorita). A Regra transmite a norma que regulamenta a Ordem franciscana. A construção desta normativa foi fundamental para inserir o movimento Franciscano na Igreja.

É a partir da entrada de companheiros que se inicia o movimento, como vemos no trecho abaixo do Testamento. Depois que o Senhor deu irmãos a Francisco, foi-lhe revelado que deveriam viver segundo a forma do Santo Evangelho.

Et postquam Dominus dedit mihi de fratribus, nemo ostendebat mihi, quid deberem facere, sed ipse Altissimus revelavit mihi, quod deberem vivere secundum formam sancti Evangelii. Et ego paucis verbis et simpliciter feci scribi et dominus Papa confirmavit mihi. ${ }^{68}$

Da experiência individual para a fraternal, Francisco não procurou nenhum seguidor, mas foram "dados" por Deus conforme o Testamentum. Primeiro os frades são três, depois viram seis; logo acrescenta-se um novo adepto e assim sucessivamente, chegando a um total de oito. Os irmãos se dividem dois a dois para partir em várias direções e testemunhar sua fé; enfim, quando atingem o número de doze - uma cópia do número dos apóstolos dirigem-se para Roma para encontrar o papa Inocêncio III (1198-1216) e pedir o reconhecimento do regulare propositum. A historiografia afirma que tanto Francisco quanto os seus companheiros tinham a consciência de que não era possível apresentar-se ao pontífice e pedir a aprovação de seu modelo de vida segundo o Evangelho sem uma formulação escrita do seu propositum, como nos informa o Testamento, sempre de forma sintética, mas clara e explícita.

${ }^{68}$ Testamentum, 14-15. Fontes Franciscani..., p. 228. 
Por um lado, a proto-Regra não se tratava de um texto redigido segundo os esquemas costumeiros e menos ainda de um documento jurídico formalmente concebido. Por outro, é possível que vestígios desta forma vitae tenham ficado no primeiro Capítulo da Regra não bulada de 1221, onde há um conjunto de passagens dos Evangelhos que em parte corresponde a trechos tirados do Novo Testamento. Consideramos que a Regula non bullata é a conclusão de uma série de tentativas e de experiências discutidas em alguns Capítulos gerais, colocadas à prova pela sua correspondência à concretitude da vida prática.

De acordo com as hagiografias de Boaventura, a primitiva fraternidade formou-se em 1208 e 1209, compreendendo homens provenientes sobretudo de Assis e do Vale de Rieti, que seriam os seguintes seguidores: Bernardo de Quintavalle, que foi o primeiro discípulo; Pedro, que foi o segundo; Egídio, que foi o terceiro; Morico, o Pequeno, que foi o quarto; Sabatino, que foi o quinto; Bárbaro, que foi o sexto; João de São Constâncio, que foi o sétimo; Angelo Tancredi, que foi o oitavo; Felipe Longo, que foi o nono; lluminado, que foi o décimo; Morico de Bernardo ludante, que foi o décimo primeiro e João de Capela, que foi o décimo segundo ${ }^{69}$. Como se verifica, o paralelo constante entre as vidas de Francisco e de Cristo são sintomáticos; os companheiros, na tradição franciscana hagiográfica, deveriam ser sempre doze, às vezes incluído e às vezes excluído Francisco de Assis; o frade lluminado às vezes não é citado. As fontes franciscanas ignoram em que tempo e espaço esses "homens da penitência", ou irmãos (fratres), mudaram para Menores (minores).

Para Manselli, apesar de ter "ganhado novos companheiros", Francisco afirmou a sua autonomia (ninguém mostrou o que ele deveria fazer), não houve sugestão ou conselho de ninguém, foi através do "desígnio divino" espelhado na fórmula "vivere secundum formam sancti evangelii" (viver segundo a forma do Santo Evangelho) que surgiu a fraternidade, sem a complicação de particulares elaborações intelectuais e jurídicas. Para Merlo ${ }^{70}$, a reconstrução do Testamento segue uma "consequencialidade plana", Deus deu alguns irmãos, o Senhor mostrou o caminho que está no seguir o Santo

${ }^{69}$ Cf. ANGELO CLARENO. Expositio super Regulam Fratrum Minorum. Aos cuidados de Pe. Giovanni Boccali, O.F.M.; intr. Felice Accrocca; trad. Ital. Pe. Marino Bigarone, O.F.M. Santa Maria degli Angeli: Edizioni Porziuncula, 1994, pp. 114-116.

${ }^{70}$ Cf. MERLO, Grado Giovanni. Op. cit., p. 27. 
Evangelho, depois Francisco fixou-o num escrito breve e simples para apresentar à autoridade máxima eclesiástica da Igreja Romana, que a confirmou, recebendo assim a autenticação oral da autoridade pontifícia. Talvez a intenção daquele que escreveu o Testamento fosse maior do que deixar uma recomendação, admoestação, exortação e recordação.

Além disso, Desbonnets acrescenta que o dito "ninguém me mostrou o que eu deveria fazer" possui diversos sentidos; um deles seria que Francisco não imitou ninguém, sendo original, e o segundo sentido subentenderia que ele teria desejado que alguém (a Igreja) tivesse dito o que fazer. Os diversos movimentos laicos penitentes do período almejavam, tal qual Francisco e seus companheiros, participação religiosa na Igreja.

Com isso constatamos que o "viver segundo a forma do Santo Evangelho" foi uma inspiração sem grandes elaborações intelectuais ou jurídicas, mas com poucas palavras e simples num escrito também breve e simples que o papa Inocêncio III (1198-1216) confirmou, mas a que concedeu apenas aprovação verbal. Como já foi mencionado, o Testamento definitivo refere " $E$ eu fiz escrever em poucas palavras e simplesmente"; depois a confirmação papal; segue uma descrição linear e isenta de conflitos. Como se verifica, não se tratou da Regula non Bullata de 1221 que contém 5.591 palavras contadas por Desbonnets ${ }^{71}$, ainda mais porque o texto da Regra não bulada revela muitas camadas na sua redação que permitiriam reconstruir-lhe a arqueologia. No entanto, todas as tentativas de reconstruir a proto-Regra de 1210, purificada de todos os acréscimos ulteriores, foram derrotadas pela historiografia e são desnecessárias do ponto de vista histórico.

O objetivo do Testamento era destinar um escrito breve a todos os frades que não conheceram a primitiva fraternitas ou como se vivia nos primeiros tempos. A recordação testamentária induziu boa parte dos historiadores, a começar por Sabatier, a elegerem este documento como algo mais próximo das origens do franciscanismo, conclusão um pouco distante dos principais comentadores da Regra do século XIV, nem tão longe de Sabatier e nem tão perto dele, Merlo define:

${ }^{71}$ Cf. DESBONNETS, Theophile. Op. cit., p. 31. 


\begin{abstract}
Siffatti silenzi non stupiscano: il Testamento è destinato ai 'fratres benedicti' $-\mathrm{e}$, forse in particolare, a quei frati che non avevano potuto conoscere la primitiva fraternità, né avevano conosciuto, se non marginalmente, l'uomo di Assisi, e a coloro che sarebbero entrati in seguito nell'ordine minoritico - , ai quali frate Francesco ripropone se stesso come criterio di identità per il presente e per il futuro. $\mathrm{E}$ l'identità francescana è per Francesco la sequela Christi secondo quanto era avvenuto, a lui in persona, di sperimentare e di vivere, prima da solo e poi in compagnia degli iniziali 'fratres', in una rigorosissima linea di ortodossia cattolico-romana e nel completo superamento di ogni e qualsiasi posizione del radicalismo di tipo 'patarinico'. [...] Nel Testamento la presentazione del passato è di tipo non tanto ricostruttivo, quanto paradigmatico. [...] Un discorso analogo è possibile per ulteriori aspetti della 'vita' su cui nel Testamtento l'Assisiate insiste: dando forza alle sue ultime volontà attraverso parole ed espressioni di tono vuoi imperativo, vuoi esortativo ('volo', 'nolo', 'rogo', 'debemus', 'firmiter volo', 'caveant', 'praecipio firmiter per obedientiam', 'teneantur', 'per obedientiam teneantur'), parole ed espressioni molto simili a quelle in precedenza segnalate per le due regole. $^{72}$.
\end{abstract}

Vale ressaltar também que o encontro da pequena comunidade com 0 papa Inocêncio III nos anos 1209 ou 1210 aconteceu num momento dos mais intricantes e difíceis do pontífice romano, tanto no plano político quanto no plano religioso. Primeiro, o papa já havia vivido a amarga e fracassada experiência da quarta cruzada. Segundo, a Alemanha causava preocupação com a luta pela sucessão do império entre os apoiadores da casa de Frederico Barba-ruiva e de Henrique VI, que tinha então o seu expoente no outro filho de Frederico, Filipe de Suábia (assassinado no dia 21 de junho de 1208 por Oto de Wittelsbach, conde palatino da Baviera), e aqueles que apoiavam o filho de Henrique, o Leão, Oto de Braunschweig. Em terceiro, o pontífice tinha o problema da heresia cátara, e não havia muito tempo que os valdenses foram condenados como heréticos; os movimentos populares penitenciais pululavam na região, o papado não podia ignorar o fenômeno de "fervor" religioso. Propor ou impor uma forma de vida que não escapasse do controle era necessário, de preferência com uma regra juridicamente firme. E por último, o papa precisava dar continuidade à reforma pontifical, finalizando-a.

$\mathrm{O}$ candidato Oto de Braunschweig, depois de prometer obediência à Igreja, teve o reconhecimento papal, foi à Itália, exatamente à Úmbria, por duas vezes, permanecendo em Assis entre dezembro de 1209 e janeiro de 1210,

\footnotetext{
72 MERLO, Grado G. "Intorno a Frate Francesco". In: I compagni di Francesco e la prima generazione minoritica. Atti del XIX Convegno Internazionale, Assisi, 17-19 ottobre, 1991. Spoleto: Centro Italiano di Studi Sull'Alto Medioevo, 1992, pp. 321-322.
} 
Provavelmente Francisco e seus companheiros souberam da passagem de grande solenidade nos arredores de Rivotorto. Muito provavelmente, após a coroação imperial de 4 de outubro de 1209, Francisco tenha partido para Roma, havendo divergências quanto a mês e ano. Segundo Manselli ${ }^{73}$, seguindo o postulado de Sabatier, o encontro teria sido na primavera de 1210. Já para Merlo as pesquisas mais recentes colocam o encontro de Inocêncio III e a fraternitas no ano de 1209.

Conforme Brenda Bolton ${ }^{74}$, a "Reforma do século XII" ou pontifical, também conhecida por "Reforma Gregoriana", durou de 1050 a 1226, coincidindo com a data da morte de Francisco de Assis. Não é correta a denominação "Reforma Gregoriana", visto que a reforma se iniciou antes do pontificado de Gregório VII (1073-1085), no pontificado de Leão IX (10491054). Seguindo a linha de Constable, a reformatio com os olhos do passado propunha um retorno ao primitivo cristianismo; com os olhos no futuro impunha um projeto de reforma eclesiástica para a toda a sociedade. As mudanças econômicas, sociais e políticas refletiram-se no conceito de vida religiosa, o que explica em parte o surgimento das novas instituições religiosas como as mendicantes, correspondendo às novas exigências e demandas espirituais. $A$ codificação das leis canônicas seria o resultado da crise religiosa do século XII, assim como tentativa de eliminar a ingerência laica nos assuntos da Igreja. No pontificado de Inocêncio III (1198-1216) houve concessões a grupos laicos e às ordens mendicantes desde que fossem incorporados à unidade e à autoridade da Igreja. Inocêncio III já havia experimentado o episódio dos valdenses e humiliati, por isso contribuiu em parte para a aceleração de um processo que culminou na forma institucionalizada da fraternitas franciscana, talvez possamos classificar tal atitude como um cerceamento da originalidade ou continuidade do movimento.

Os Concílios de Latrão I, II e III, realizados respectivamente em 1123, 1139 e 1179 fizeram parte do projeto de Reforma e foram concebidos após um tipo de perturbação que afetava diretamente o papado. A maior preocupação dos pontífices era principalmente no tocante à disciplina e à autoridade da

\footnotetext{
${ }^{73}$ Cf. MANSELLI, Raoul. Op. cit., pp.100-101.

${ }^{74}$ Cf. BOLTON, Brenda. A Reforma na Idade Média século XII. Lisboa: Edições 70, 1983, pp. 14-16.
} 
Igreja sobre o Império. Já o IV Concílio de Latrão foi convocado em 19 de abril de 1213, e iniciou-se no dia 1 de novembro de 1215 no Palácio de Latrão, em Roma. Foi o maior dos concílios ecumênicos da Idade Média. Como resultado, tivemos setenta e um decretos reformadores ou constituições disciplinares. $\mathrm{O}$ cânone treze correspondeu diretamente às Ordens Mendicantes, Inocêncio III instituiu que as novas ordens religiosas e os novos grupos deveriam escolher as regras já existentes - Regra de São Basílio, Regra de Santo Agostinho, Regra de São Bento, respectivamente, regras eremítica, monástica e canonical. No entanto, talvez devido ao fato de Francisco e seus primeiros irmãos terem se encontrado com o papa Inocêncio III em 1210, pedindo aprovação verbal para a proto-Regra e prometendo obediência ao clero em geral, tivemos a criação de um novo gênero de regra, a Regra Apostólica ${ }^{75}$, com diferenças em relaçao às outras, apesar de presentes alguns preceitos beneditinos na Regra definitiva dos Frades menores; desenvolveu-se juridicamente ao longo de quatorze anos, resultando na Regula bullata e obtendo aprovação escrita com a bula Solet annuere de 29 de novembro de 1223 no pontificado de Honório III (1216-1227) ${ }^{76}$. Em relação ao movimento Franciscano, interessa-nos sobretudo o IV Concílio de Latrão, especificamente o cânone treze.

13. De l'interdiction des ordres religieux nouveaux. De peur qu'une trop grande diversité d'ordres religieux n'introduise une grave confusion dans l'Église de Dieu, nous interdisons formellement de fonder à l'avenir tout nouvel ordre: quiconque entend se vouer à l'état religieux doit choisir un ordre approuvé. De même, quiconque veut fonder une nouvelle maison religieuse, doit recevoir la Règle et l'institution des ordres religieux approuvés. Nous interdisons

\footnotetext{
${ }^{75} \mathrm{O}$ modelo Apostolorum possui características específicas, principalmente em relação a pregação. A Ordo hierarchicus era uma mentalidade vigente em que se considerava a pregação (incluía a cura das almas) como direito reservado e único e exclusivamente aos que eram chamados por Deus. Esta vocação por parte de Deus era compreendida de modo restritivo pois somente os 12 apóstolos e seus sucessores (os bispos), os discípulos de Cristo e seus sucessores (párocos e vigários) tinham autoridade para exercer a pregação. Os monges e leigos não entravam no ordo hierarchicus exceto aqueles designados a cura das almas e responsáveis pelo seu território. Um exemplo ilustrativo disso foi Pedro Valdo e seus seguidores que foram expulsos pelo bispo de Lião por causa da pregação não autorizada. Valdo foi para Roma em 1179, pedindo a Alexandre III e ao III Concílio de Latrão uma autorização para o modo de vida de pobreza e a pregação intinerante. Mas ele não foi aprovado no exame bíblico e sacramental. As Ordens Mendicantes tinham a pregação como objetivo principal de atuação na Igreja. GRUNDMANN, Herbert. Religious movements in the middle ages. London: University of Notre Dame Press, 1995, p. 7.

${ }^{76}$ Ver: VENDITTELLI, Sandro Carocci-Marco. Onorio III. In: ENCICLOPEDIA dei Papi. Roma: Istituto della Enciclopedia italiana, 2000, 2v, pp. 350-362.
} 
également de se faire recevoir moine en plusieurs monastères, et à tout abbé de présider à plusieurs monastères. ${ }^{77}$

Conforme o trecho acima, estabeleceu-se a proibição da criação de novas ordens religiosas, afim de evitar a variedade de ordens que causassem confusão na Igreja. Aos que desejassem abraçar a vida religiosa, recomendava-se que o fizessem nas ordens já aprovadas, do mesmo modo se uma nova casa religiosa fosse fundada, que assumisse a regra e a ordenação já aprovadas. O papa jurista optou em receber os diversos grupos religiosos e ser acessível, desde que o propositium não questionasse a fé ortodoxa e a autoridade eclesiástica e, sobretudo, seguisse as regras já instituídas, como vimos interditou-se a criação de novas regras. No canône três, intitulado "Dos heréticos" podemos aferir como a igreja estabelecia a distinção entre os heréticos e os não heréticos, os limites desta fronteira eram bastante tênues, visto que muitos movimentos heréticos eram análogos aos princípios do movimento Franciscano na sua formação, como por exemplo, os valdenses ${ }^{78}$.

\begin{abstract}
... la conferma dell'Ordine, come nel caso dei Minori, fu concessa solo sotto Onorio III. II canone 13 del IV concilio Lateranense (Ne nimia religionum), che proibiva l'introduzione di nuovi Ordini religiosi e orientava gli aspiranti verso le Regole già approvate, non ha infatti nulla a che fare direttamente con Francesco o Domenico, ma esprime la preoccupazione di disciplinare i movimenti religiosi in rapido sviluppo con le loro molteplici forme di comunità. II canone rimase, d'altronde, lettera morta. ${ }^{79}$
\end{abstract}

Diferentemente do movimento Franciscano, desde os primórdios, os dominicanos eram formados por clérigos e seguiram um caminho apoiado pelas diretrizes da Igreja. Em 1215, durante o IV Concílio de Latrão, o espanhol de origem nobre Domingos de Gusmão, acompanhado do bispo Foulques de Toulouse, partiu para Roma, para obter aprovação do papa da recente Ordem

\footnotetext{
${ }^{77}$ Cf. FOREVILLE, Raymonde. Latran I, II, III et Latran IV. Paris: Éditions de L'Orante, 1965, p. 354. Segundo Charles-Joseph Hefele, o cânone treze foi inserido no Corpus juris canonici da Igreja no lib. III, tit. XXXVI, De religiosis, cap. 9. HEFELE, Charles-Joseph. Histoire des Conciles: d'apres les documents originaux. Deuxieme partie. Paris: Letouzey et Ané, Editeurs, 1913 , p. 1344.

${ }^{78}$ Para Manselli, o movimento Franciscano nasceu de uma tensão profunda entre a exigência de regulamentação e o impulso espiritual, cada vez mais vivo quanto maior era o sucesso do frades. MANSELLI, Raoul. Op. cit., p. 103.

${ }^{79}$ Ver MALECZEK, Werner. Innocenzo III. In: ENCICLOPÉDIA dei Papi. Roma: Istituto della Enciclopedia italiana, 2000. 3 v., p. 340. Ver também: BURGAUX, Ch. Histoire des Papes. Versaliis: Persan, 1949, pp.142-143; BARRACLOUGH, Geoffrey. Papas na Idade Média. Lisboa: Verbo, 1972.
} 
mendicante, aprovação dada em 22 de dezembro de 1216. Foram intitulados pelo papado como Ordo Fratrum Praedicatorum (Ordem dos Irmãos Pregadores). No entanto, pelo fato do Concílio ter acabado de proibir a criação de novas ordens religiosas, os dominicanos adotaram uma regra já existente, a regra de Santo Agostinho, apresentando-se canonicamente como cónegos regulares ${ }^{80}$. Para os dominicanos, diferente dos franciscanos, a pobreza era antes de mais nada uma arma contra as heresias.

Como já foi dito, no ano de 1210 a pequena e original fraternidade era identificada na forma institucional de fraternitas e não o de uma "ordem" religiosa propriamente dita, ao menos no sentido canônico do termo. Após a viagem a Roma, novos fratres se uniram ao grupo, como João de Nottiano (chamado o Simples), Rufino de Scipione, Leonardo, Leão, Junípero, Tiago, Tebaldo, Agostinho, Masseu de Marignano, Elias, lluminato de Arce, Pacífico, Simão de Collazzone. Para Merlo ${ }^{81}$, eles representariam a ligação entre os socii dos inícios e a primeira geração menorita que ampliou a área e a quantidade de recrutamento. Em resumo, a primeira geração menorita foi composta por um grupo bastante heterogêneo em termos de idade, proveniência social e cultura: nobres, cavaleiros, leigos, clérigos (sacerdotes ou não), membros da aristocracia urbana e homens comuns, iletrados, letrados, ricos, pobres, citadinos e camponeses.

Ademais, a nova formação religiosa exercia uma fascinante atração, que crescia rapidamente porque não tinha limitações para a inserção de novos "irmãos"; qualquer homem poderia tornar-se um menor, independente da idade, da condição social, da cultura, porque era aberta aos mais variados indivíduos e às mais diferentes experiências. Por uma exigência canônica o regulare propositum comprometia-se com os três votos comuns às outras comunidades religiosas, a saber, o viver comunitariamente (não individualmente) na obediência, na pobreza e na castidade. Com o passar do tempo, a identidade da nova formação religiosa começou a se exprimir, durante o crescimento de consciência dos Menores e do confronto com a sociedade civil e eclesiástica, o que contribuiu para a elaboração de uma linguagem peculiar. Depois de um

${ }^{80}$ Cf. VAUCHEZ, André. “São Domingos, 'o mal-amado'”. In: BERLIOZ, Jacques. Monges e religiosos na Idade Média. Lisboa: Terramar, 1994, p. 265.

${ }^{81}$ Cf. MERLO, Grado Giovanni. Em nome de São Francisco. História dos Frades Menores e do franciscanismo até início do século XVI. Petrópolis: Vozes, 2005, p. 29. 
início conturbado, a fraternitas franciscana vivia uma fase de crescimento progressivo que trazia uma multiplicidade de problemas para a Igreja devido à falta de uma regulamentação.

O maior problema configurou-se na combinação do processo de crescimento rápido e de quase nenhuma normativa institucional. Essa descentralização e non stabilitas locii (não tinham lugar fixo como 0 monaquismo tradicional) preocuparam as autoridades eclesiásticas pois a fraternitas começou a ganhar uma expressão significativa e "a simplicidade das origens não simplificou a solução dos complexos problemas acarretada pelo enorme crescimento do conjunto de fiéis", uma evolução institucional da fraternidade se iniciava ${ }^{82}$.

A circunscrição geográfica da fraternitas limitava-se à Igreja de Santa Maria dos Anjos, a Porciúncula e outros pequenos centros - o Cárcere perto de Assis, as celas de Cortona, Greccio e outros locais no Vale do Rieti. Mas, a nova religio, que se refugiou por vários anos numa base jurídica ainda não bem definida, reunia um grupo de pregadores itinerantes inevitavelmente em contato com a instituição eclesiástica, principalmente com os bispos, nem sempre podia inspirar à todos imediata confiança. Por isso, Inocêncio III havia concedido uma aprovação oral, evitando comprometer-se com um pronunciamento escrito; no entanto, o aumento desordenado do movimento Franciscano necessitava de uma definição institucional mais clara e objetiva ${ }^{83}$.

O crescimento do movimento Franciscano não se restringiu ao campo masculino. No dia 18 de março de 1212, num Domingo de Ramos, após ouvir e acolher a pregação de Frei Francisco, Clara de Favarone de Offreduccio entrou para o estado penitencial sancionado pelo corte dos cabelos, que não sabemos ao certo se teria sido feito pelo pobre de Assis, diante do altar de Santa Maria dos Anjos. Clara tinha pouco menos de vinte anos e pertencia a uma importante família da aristocracia assisiense de tradição senhoril. Clara, junto com algumas parentas, iniciou a vida religiosa no mosteiro beneditino de São Paulo, localizado perto de Assis, no caminho para Perugia, dando início à

\footnotetext{
${ }^{82}$ MERLO, Grado G. Op. cit., p. 29-32.

83 CAROLI, Ernesto (org.) Fonti Francescane, nuova edizione. Scritti e biografie di san Francesco d'Assisi. Cronache e altre testimonianze Del primo secolo francescano. Scritti e biografie di santa Chiara d'Assisi. Testi normativi dell'Ordine Francescano Secolare. Padova: Editrici Francescane, 2004, p.1705.
} 
formação de uma pequena comunidade em São Damião. As "sorores minores" seguiam o princípio da fidelidade ao Evangelho com o respectivo testemunho cristão, pobre e exemplar, criando um estreito laço com Frei Francisco e seus irmãos ${ }^{84}$. O movimento religioso feminino Franciscano de inspiração evangélico-pauperista talvez serviu de modelo para o enquadramento institucional de diversas comunidades religiosas femininas da região.

Além disso, o movimento Franciscano também não se restringiu à Península Italiana, por isso era crescente a exigência de uma definição jurídica definitiva pressionada pela instituição eclesiástica. A preocupação de autoridades eclesiásticas começou a tornar-se cada vez maior a partir da experiência advinda de fora de Assis. Em 1212/1213, Francisco e companheiros fracassaram na viagem à Terra Santa. Mesmo assim, entre 1217 e 1219, verificamos uma extraordinária difusão geográfica do movimento Franciscano, com as primeiras tentativas de missão além dos Alpes e além do mar, a chegada dos primeiros frades na Península Ibérica à França, à Alemanha, Hungria, crescimento em toda a península Italiana, etc. As tentativas missionárias fora de Assis em geral foram desastrosas, prova disso seria o relato do martírio de cinco frades no Marrocos em 1220.

Por outro lado, o ano de 1217 foi crucial para a fraternidade com a entrada de Hugolino de Óstia. Temos o início da intervenção da Igreja através da habilidade política do cardeal Hugolino, futuro papa Gregório IX (12271241), que teve uma atuação ainda mais significativa na Ordem franciscana durante o seu pontificado. Não é por acaso que a entrada de um representante oficial da Igreja Romana no movimento Franciscano teve um significado maior do que a historiografia tradicional assinala.

Hugolino dei Conti di Segni ${ }^{85}$ nasceu no ano de 1170 em Anagni, cidade na qual recebeu a sua primeira formação. Sobrinho de Inocêncio III, foi cardeal-bispo de Ostia e Velletri. Contudo, a carreira de Hugolino não se iniciou apenas com a subida de Lotario dei Conti di Segni como papa Inocêncio III. Embora no ano de 1198 Hugolino tenha sido elevado ao cargo de capelão

\footnotetext{
${ }^{84}$ Cf. MERLO, Grado G. Op. cit., pp. 86 e 87.

85 CAPITANI, Ovidio. Gregorio IX. In: ENCICLOPÉDIA dei Papi. Roma: Istituto della Enciclopedia italiana, 2000. 3 v., p. 363. Ver também BURGAUX, Ch. Op. cit., pp.144-145.
} 
papal e de cardeal diácono de São Eustáquio, somente em 1206 tornou-se cardeal-bispo de Óstia.

O cardeal Hugolino encontrou-se pela primeira vez com Francisco de Assis no dia 14 de maio de 1217 na cidade de Firenze, exatamente depois de um Capítulo geral dos frades, celebrado na Porciúncula, dentro da qual havia sido decidido o envio de frades pelo mundo cristão e fora da ltália. A partir deste momento, o cardeal de Óstia teria iniciado a sua atuação política dentro da fraternidade. Era um momento delicado para os frades, porque a fraternitas não se tinha adequado às prescrições conciliares com a sua nova forma de vida, somente havia obtido a aprovação oral dada pelo papa Inocêncio III em 1209. Por isso, a pedido de Francisco de Assis, o papa Honório III teria dado um "protetor" aos franciscanos, mas o nome de "dominus de Ostia" teria sido escolhido pelo próprio Frei Francisco, segundo a lgreja. A função do cardeal protetor era corrigir as situações de perturbação. Ele agia como um guia disciplinador "externo", que cuidava das intervenções coercitivas que aos poucos se tornavam necessárias e também exercia influência para a formulação de uma Regra definitiva, mais articulada e orgânica, para ser submetida à aprovação pontifícia ${ }^{86}$. O enquadramento institucional do movimento Franciscano iniciou-se com a criação do cargo de cardeal protetor do grupo, e o ano de 1217 assinalou a preparação para um adequamento às normativas canônicas da Igreja e, principalmente, a criação de uma organização dentro de um movimento que estava desordenado. Conforme John Moorman, as divisões geográficas da primeira expansão eram as seguintes.

Nel capitolo generale di 1217 si decise di mandare delegazioni in paesi fuori d'Italia, e di dividere la sfera del lavoro in um certo numero di province, ognuna col suo proprio ministro, che doveva essere responsabile di ciò che si faceva. L'Italia era allora divisa in sei province - Toscana, Lombardia, le Marche di Ancona, Terra di Lavoro, Pulia e Calabria. La Francia fu divisa in due province, uma per il nord e uma per il sud. Una provincia fu creata per la Germania, benché nessun frate fosse ancora andato là. In Spagna fu creata una provincia, come anche in Terra Santa. ${ }^{87}$.

\footnotetext{
${ }^{86}$ Cf. MERLO, Grado G. Op. cit., p. 38.

${ }^{87}$ MOORMAN, John. Op. cit., p. 272.
} 
Em 1218, o cardeal Hugolino di Segni recebeu do papa Honório III a bula Litterae tuae nobis (primeiro documento do Bollarium Franciscanum), na qual foi estabelecida uma intervenção direta nas comunidades femininas que ficariam subordinadas à Igreja, inclusive em relação à propriedade do mosteiro, na ocasião foi imposta a adoção da regra beneditina e a clausura rigorosa para as sorores, conforme o monaquismo tradicional. $O$ enquadramento do movimento feminino Franciscano deu-se de uma forma mais rápida que o dos fratres minores. São Damião era a igreja restaurada por Frei Francisco e se transformou no lugar da religião "franciscana" para Clara e suas companheiras. Com habilidade rápida, o protetor da fraternitas franciscana agia até mesmo na denominação do mosteiro, que passou a ser denominado de Santa Maria de São Damião, porque o cardeal Hugolino queria que seus mosteiros femininos tivessem a comum dedicação à Virgem Maria ${ }^{88}$. Já em 1219, ele elaborou uma forma vitae para as comunidades femininas de inspiração pauperista.

De 1219 a 1223, situam-se algumas premissas conflitantes da história da Ordem; além das pressões curiais, parecem surgir as primeiras divergências entre os frades. No ano de 1220, no dia 29 de setembro, Francisco renuncia à direção do movimento, passando-a a Pedro Cattani, o "prelado" da Ordem. Pedro morre no ano seguinte, sendo substituido por Frei Elias. A Ordem havia crescido e já se modificava muito em relação ao pequeno grupo das origens (fraternitas).

Antes da formulação da Regula non bullata de 1221, o papa Honório III testemunhou o seu apoio à expansão dos frades através da Carta Cum dilecti de 11 de junho de 1219, o primeiro documento pontifício a respeito do movimento Franciscano, no qual se recordam "Frei Francisco e companheiros da vida e religião dos Frades menores" e a sua "forma de vida com justa razão aprovada pela Igreja Romana". O papa Honório III deu um nome definitivo ao grupo, o termo "Frades menores", que aparecerá somente na redação da Regra de 1223 e não na Regra de 1221.

$\mathrm{Na}$ verdade, os frades pediam cartas à Santa Sé em apoio aos lugares que tinham dificuldades de se instalarem, por exemplo, Alemanha, Hungria, Inglaterra, parte da França, etc. A bula Cum dilecti é endereçada a todos os

${ }^{88}$ MERLO, Grado G. Op. cit., pp. 86-89. 
arcebispos, bispos, decanos, arquidiocesanos e outros prelados das igrejas e o seu conteúdo deixa claro ainda uma incerta situação institucional porque se evitava o uso do termo "Ordem" e usava-se o termo "Comunidade dos supracitados frades", que são "homens católicos e fiéis" (leia-se dentro da ortodoxia Romana como vemos abaixo).

Onorio vescovo, servo dei servi di Dio, ai venerabili fratelli arcivescovi
e vescovi e ai diletti figli abati, decani, arcidiaconi e agli altri prelati
delle chiese [invia] salute e apostolica benedizione.
Poiché i diletti figli frate Francesco e i suoi compagni, appartenenti
alla vita e Religione dei frati minori, dopo aver abbandonato le vanità
del mondo, hanno scelto una via di vita meritamente approvata dalla
Chiesa romana, e si spandono per le diverse parti del mondo, dietro
l'esempio degli apostoli seminando il seme della divina parola;
mediante questa lettera apostolica vi significhiamo la nostra preghiera
ed esortazione.
Che cioè, quando i latori della presente lettera, appartenenti alla
comunità dei predetti frati, riterranno di dover passare tra voi, li
accogliate come uomini cattolici e fedeli, e in ogni caso vi mostriate a
loro favorevoli e benigni, per riverenza verso il Signore e verso di
noi. ${ }^{89}$

No ano seguinte, entretanto, o papa vê-se forçado a defender os Menores frente aos bispos e prelados da Igreja na França, testemunhado pela Carta Pro dilectis de 29 de maio de 1220, na qual Honório III garantiu a ortodoxia da nova religio e, talvez, reforçou o seu apoio ao mudar a terminologia de "religione e vita" para "Ordine dei frati minori", termo que aparecerá somente na Regra de 1223. Francisco e companheiros até aquele momento não haviam denominado ou usado a palavra Ordo que aparece quatro vezes na Pro dilectis. A mudança da terminologia revelou um reconhecimento canônico maior que a bula anterior. Porém, os termos usados para descrever os Frades menores são os mesmos da bula Cum dilecti: "catholicos et devotos (fideles)", verdadeiramente católicos e obedientes à Sé apostólica.

Onorio vescovo, servo dei servi di Dio, ai venerabili fratelli arcivescovi e vescovi e ai diletti figli abati, priori, e agli altri prelati delle chiese, costituiti per il Regno di Francia, [invia] salute e apostolica benedizione.

\footnotetext{
${ }^{89} \mathrm{O}$ grifo é nosso para destacar os termos. Existem controvérsias sobre a datação desta Carta papal, a data mais utilizada pela historiografia é 11 de junho de 1219, cf. nota um da "Bolla Cum dilecti di Onorio III". In: CAROLI, Ernesto (org.) Fonti Francescane, nuova edizione...., p. 1709.
} 
Rammentiamo d'aver indirizzato a voi una nostra lettera in favore dei diletti figli, i frati dell'Ordine dei frati minori, perché li riteneste come raccomandati, nella luce del divino Amore. Ma, come ci è stato riferito, alcuni tra voi, come se avessero una coscienza dubbiosa nei riguardi di questo Ordine pur non trovando in essi ragione di sospetto, come abbiamo udito da altri ai quali possiamo concedere piena fede, non permettono ad essi di rimanere nelle loro diocesi sebbene, per il solo fatto che noi abbiamo consegnato loro nostre lettere, non si dovrebbe pensare nulla di sinistro nei loro riguardi.

Perciò vogliamo che sai noto a tutti voi che noi riteniamo il loro Ordine tra quelli approvati e riconosciamo i frati di questo Ordine come cattolici e devoti [alla Chiesa romana].

Abbiamo perciò ritenuto di ammornirvi ed esortarvi rendendovi noto mediante lettere apostoliche ciò che comandiamo: che cioè li ammettiate nelle vostre diocesi come uomini veramente fedeli e religiosi, e li abbiate come raccomandati in modo tutto particolare, per riverenza al Signore e a noi. ${ }^{90}$

Entretanto, a bula mais significativa foi promulgada no dia 22 de setembro de 1220, porque mostrou um indício concreto da futura institucionalização do movimento Franciscano, principalmente com 0 estabelecimento do ano de noviciado. Assim, Honório III emitiu a Carta Cum secundum impondo o ano de noviciado aos Frades menores. Antes, tinhamos a entrada livre e imediata de novos membros, o que causava preocupação das autoridades eclesiásticas, crescia a pressão para que o movimento Franciscano elaborasse uma Regra definitiva para evitar embaraços nas cidades em que pregavam e não serem confundidos com heréticos. Tanto na regra de 1221 quanto na de 1223, a imposição pontifícia de noviciado fora incorporada de forma literal, sem modificações.

\begin{abstract}
Onorio vescovo, servo dei servi di Dio, ai diletti figli priori e custodi dei frati minori, salute e apostolica benedizione [...]

Perciò, con l'autorità della presente lettera vi proibiamo di ammettere qualcuno alla professione del vostro Ordine, se non avrà fatto prima l'anno di prova. E una volta fatta la professione, nessun frate osi lasciare il vostro Ordine e a nessuno sai lecito accettare colui che ha lasciato l'Ordine.

Vietiamo inoltre che alcuno di voi possa andare in giro fuori dell'obbedienza con l'abito della vostra Religione e corrompere la purezza della vostra povertà. Se alcuno poi presumerà di farlo, sia lecito a voi infliggere contro tali frati le censure ecclesiastiche fino a quando si sai ravveduto. ${ }^{91}$
\end{abstract}

\footnotetext{
${ }^{90}$ O grifo é nosso para destacar o termo Ordine e uomini veramente fedeli e religiosi. "Bolla Pro dilectis di Onorio III". In: CAROLI, Ernesto (org.) Fonti Francescane, nuova edizione...., p. 1710. 91 "Bolla Cum secundum di Onorio III". In: CAROLI, Ernesto (org.) Fonti Francescane, nuova edizione...., pp. 1710 e 1711. Cf. "Il 22 settembre 1220, con la lettera Cum secundum consilium, intervenne sulle strutture interne della "fraternitas" francescana, favorendone l'assimilazione agli Ordini religiosi già esistenti e sancendo, oltre al noviziato annuale, il potere coattivo dei superiori sui frati". VENDITTELLI, Sandro Carocci-Marco. Onorio III. Op. cit., p. 361.
} 
Em parte, ao fazer-se a leitura destas três bulas de Honório III, revelase um certo ajustamento da fraternitas de maneira significativa. A justificativa de intervenção da Igreja Romana sempre se fundamentava no problema da heresia e no "fervor religioso" dos movimentos populares que precisavam ser incorporados ao projeto de "Reforma" religiosa da Cúria Romana. De uma certa forma, atestamos um encaminhamento para a institucionalização através das três cartas papais acima mencionadas e uma aceleração do processo de adequamento jurídico do movimento Franciscano, da transformação da fraternitas à Ordo clericorum.

\subsection{Etapas da evolução da legislação Franciscana: uma releitura das Regras}

A "lex fundamentalis" do movimento Franciscano são as regras, sobretudo a Regra de 1223. Fontes importantes não somente por serem os principais documentos legislativos da Ordem, mas também porque serviram de base para a composição das primeiras hagiografias e demais fontes relativas a Francisco.

Os primórdios da historiografia crítica franciscana acerca do estudo das Regras e Testamento se fixam no século XIX com o protestante Paul Sabatier, com a obra "Vida de São Francisco"92, publicada no ano de 1894, que marcou uma nova época no campo do franciscanismo e dos estudos histórico-críticos das fontes franciscanas. Conforme Paul Sabatier, há três fases para a institucionalização. A primeira é em 1210, quando as palavras de Francisco de Assis expressadas eram mais belas do ponto de vista místico e tinham pouca correspondência com aquilo que se esperava de uma regra. Não possuíam nem a precisão, nem as formas breves e imperativas da Regra de $1223 .{ }^{93}$ Entre a proto-Regra de 1210 e a Regra de 1223 aprovada pelo papa, de comum só possuíam o nome. A Regra de 1210 era "espontânea", correspondendo à fase franciscana propriamente dita; a Regra de 1221

\footnotetext{
${ }^{92}$ Cf. SABATIER, Paul. Vida de São Francisco. Bragança Paulista: Editora Universitária São Francisco: Instituto Franciscano de Antropologia, 2006.

${ }^{93}$ SABATIER, Paul. Op. cit., pp. 278-279.
} 
representaria uma fase intermediária; por sua vez, a terceira fase, com a aprovação da Regra de 1223, seria uma fase de um contrato mediado pela Igreja. Para ele, o Testamento seria algo mais próximo ao franciscanismo das origens, porque contém uma recordação, admoestação e exortação dada por Francisco no seu leito de morte, além de uma reflexão dos primeiros tempos.

Atestamos que as pesquisas de Sabatier inauguraram a crítica historiográfica moderna sobre as fontes atribuídas a Francisco de Assis. No entanto, criticar negativamente Sabatier nos dias atuais faz parte da historiografia franciscana mais conservadora. O que Sabatier apresenta sobre a Regra de 1210 é uma hipótese, visto que ele não teve contato direto com esta fonte. Entretanto, nos dias atuais, diminuir a contribuição de Paul Sabatier e da sua Escola aos estudos franciscanos é ineficaz.

Outro aspecto que nos parece problemático é a afirmação de Malcolm D. Lambert de que: "O programa institucional do generalato foi por outros julgado como uma traição ao ideal de Francisco; permitindo o relaxamento sob a forma de moderação, teria conduzido a Ordem ao seu sucessivo decaimento. Esta foi a opinião dos Espirituais e dos seus descendentes na Ordem, também de Sabatier e sua escola, e de alguns franciscanos posteriores." 94 . Sabatier foi original na sua abordagem e não seguiu as concepções dos Espirituais franciscanos como nos aponta a historiografia mais conservadora que exemplificamos com as palavras de Malcolm D. Lambert, visto que Sabatier desvalorizava as Regras porque, para ele, a "lex fundamentalis" estaria distante da prática da pobreza franciscana e ao mesmo tempo valorizava em exagero o Testamento como algo mais próximo das origens do franciscanismo; mas os Espirituais do século XIV colocavam ambos os documentos num mesmo plano de igualdade jurídica e ao mesmo tempo valorizavam os dois documentos. Portanto, as acusações dos Espirituais franciscanos sobre o relaxamento da pobreza dentro da Ordem dos frades da Comunidade e suas análises no tocante às Regras e Testamento pouco têm a ver com os postulados de Sabatier, não apenas pela diferença temporal mas também pelo uso das fontes.

\footnotetext{
${ }^{94} \mathrm{Cf}$. LAMBERT, Malcolm D. Povertà Francescana. La dottrina dell'assoluta povertà di Cristo e degli Apostoli nell'Ordine Francescano (1210-1323). Milano: Edizioni Biblioteca Francescana, 1995, p. 109.
} 
Assim, Sabatier não estava tão distante quando expôs as suas pesquisas em relação às Regras e Testamento de Francisco. Prova disto é uma historiografia inovadora como Desbonnets que nos deixa isso bem claro ao citar Bartoli-Langeli na seguinte passagem:

\begin{abstract}
A Regra aprovada por Honório III, em 1223, está, objetivamente, bem distanciada da 'vida' proposta por Francisco, em 1209-1210, a Inocêncio III, elaborada depois até 1221 , e finalmente repetida no Testamento, em 1226. Esta última, derradeira e extrema reivindicação de Francisco que propunha sua própria experiência religiosa como modelo normativo, será por Gregório IX reduzida a não passar de um simples testemunho espiritual. [...] A seguir, a lógica da instituição e do Direito não mais encontrarão obstáculos entre os franciscanos, levados a encontrar uma legitimação inatacável na autenticidade das provas escritas. ${ }^{95}$.
\end{abstract}

Segundo ambos autores, o Testamento foi classificado como um simples testemunho por Gregório IX (1227-1241), em 1230, por meio da Carta Quo Elongati e a Regra de 1223 foi designada a única "lei constitutiva" da Ordem, assunto que desenvolvemos melhor no segundo capítulo desta dissertação. O que representou a Regra não bulada de 1221 para o movimento Franciscano? Para dar continuidade às nossas indagações, partimos para a análise das normas franciscanas.

A metodologia para analisar as fontes não se restringe apenas a uma análise comparada das Regras Franciscanas ${ }^{96}$, visando às permanências e às rupturas $^{97}$ que ocorreram entre a Regra não Bulada de 1221 e a Regra Bulada de 1223, e, sim, a uma análise do significado de alguns termos jurídicos empregados que representam a definitiva institucionalização e uma das metamorfoses do movimento Franciscano. Numa singela comparação

\footnotetext{
${ }^{95}$ DESBONNETS, T. Op. cit., pp. 114-115.

96 Ao longo do trabalho utilizamos as fontes em latim da publicação de MENESTÒ, Enrico \& BRUFANI, Stefano (org.). Fontes Franciscani. Assis: Edizioni Porziuncola, 1995.

${ }^{97}$ A pesquisa em quadros comparativos das Regras foi feita por Cibele Carvalho, na sua dissertação ela preocupou-se principalmente em mostrar as permanências e as rupturas entre as duas regras. Cf. CARVALHO, Cibele. Francisco de Assis entre duas Regras (1221-1223). Dissertação de Mestrado. Curitiba: Universidade Federal do Paraná, 2005. A nossa preocupação neste trabalho é a construção da norma e a evolução da pobreza franciscana dentro das práticas juridícas do movimento, pensando não só na relação Regra-Testamento, já que consideramos o Testamento como parte dos documentos legislativos, mas também pensando nas interpretações das normas por diversos papas e por dois frades, a saber, Boaventura de Bagnoregio (1221-1274) e Angelo Clareno (1245-1337), dois opostos que produziram debates no interior da Ordem no tocante a paupertas. Ademais, compreender 0 significado de alguns termos do latim usado nas fontes são imprescindíveis para o nosso trabalho.
} 
percebemos que o texto de 1223 é mais breve, conciso e enxuto, enquanto o texto de 1221 é mais longo e com muitas passagens bíblicas. Em primeiro lugar, a Regra não bulada de 1221 contém 23 capítulos e a Regra bulada de 1223 contém 12 capítulos. Em termos de número de palavras a Regra de 1221 é bem mais extensa, contendo um pouco mais que o dobro de frases que a Regra de 1223. Em segundo lugar, em termos de conteúdo, a Regra de 1223 é mais jurídica com fórmulas mais fortes, precisas, concisas e diretas. Assim, a Regra de 1221 é menos objetiva, contendo mais citações bíblicas evangélicas ao longo dos capítulos. Outra observação pertinente às duas Regras consiste no emprego da primeira pessoa do singular na redação dos textos, conforme nos explica Vauchez, mas trata-se de uma coisa única na Idade Média, sobretudo na regra de uma ordem religiosa; o fundador dos Menores utilizou vários inícios de frases na primeira pessoa do singular para dar ordens ou denunciar comportamentos contrários ao espírito evangélico: "Eu aconselho, eu admoesto, e eu exorto aos irmãos...", "Eu proibo firmemente a todos os irmãos..."98.

Sobre a Regra de 1221, Vauchez ainda faz uma observação importante de que também esta regra era atípica e pouco satisfatória aos olhos dos canonistas; não foi aceita pelo papado que recusou promulgá-la, por isso recebeu o nome de regula non bullata (regra não bulada) que talvez foi empregado devido a uma designação. ${ }^{99}$. Enfim, a Regula non bullata acentua ainda mais a obediência à hierarquia no sentido de voto obrigatório, sendo que algumas frases foram adaptadas de acordo com o direito canônico do período; entretanto, ainda não estava adequada ao texto jurídico de uma Regra.

Para pensar o projeto primitivo e a construção da norma no movimento Franciscano prosseguimos a seguir com uma análise comparativa geral e minuciosa de alguns capítulos da Regra Bulada para a Regra não bulada que resultaram em algumas considerações ${ }^{100}$. Primeiramente, houve mudanças que manifestaram em muito a evolução jurídica das normas no movimento Franciscano, processo de desenvolvimento, mas que para Desbonnets não teria modificado o espírito do franciscanismo das origens, seria possível

\footnotetext{
${ }^{98}$ VAUCHEZ, André. Op. cit., p. 193.

${ }^{99}$ VAUCHEZ, André. Op. cit., p. 169.

100 Para fazer a comparação geral entre as duas Regras empregamos o capítulo IX. DESBONNETS, T. Da intuição..., pp. 94-105.
} 
encontrarmos resquícios deste primitivismo, principalmente nos seguintes trechos do primeiro capítulo da Regra não bulada: "Si vis perfectus esse, vade (Mat 19,21) et vende omnia (Luc 18,22) quae habes, et da pauperibus et habebis thesaurum in caelo; et veni, sequere me (Mat 19,21). Et: Si quis vult post me venire, abneget semetipsum et tollat crucem suam et sequatur me (Mat 16,24). Item: Si quis vult venire ad me et non odit patrem et matrem et uxorem et filios et fratres et sorores, adhuc autem et animam suam, non potest meus esse discipulus (Luc 14,26). Et: Omnis, qui reliquerit patrem aut matrem, fratres aut sorores, uxorem aut filios, domos aut agros propter me, centuplum accipiet et vitam aeternam possidebit (cfr. Mat 19,29; Mar 10,29; Luc 18,29)."101. Esses excertos correspondem a citações evangélicas literais que desaparecem totalmente na Regra bulada.

Ademais, ao compararmos as duas Regras o que se sobressai é um notável rearranjo jurídico e estilístico das palavras, por exemplo, a Regula Bullata emprega a forma plural da palavra, fratres (irmãos/frades) ao longo do texto, enquanto a Regula non Bullata utiliza a forma singular frater (irmão), exemplo disso encontra-se no trecho inicial do capítulo XVII da Regula sine bulla, "Nullus frater praedicet contra formam et institutionem sanctae Ecclesiae et nisi concessum sibi fuerit a ministro suo", passa a ser na Bullata, no capítulo IX "Fratres non praedicent in episcopatu alicuius episcopi, cum ab eo illis fuerit contradictum" ${ }^{\prime 102}$.

Em segundo lugar, no capítulo um de título "In nomine Domini! Incipit vita Minorum Fratrum", notamos um significativo desaparecimento de citações evangélicas que se encontravam na Regula sine Bulla. Além disso, a fórmula inicial "Regula et vita istorum fratrum haec est, scilicet vivere in obedientia, in castitate et sine proprio, et Domini nostri Jesu Christi doctrinam et vestigia sequi, qui dicit: Si vis perfectus esse, vade et vende omnia quae habes, et da pauperibus et habebis thesaurum in caelo; et veni, sequere me" transformou-se em "Regula et vita Minorum Fratrum haec est, scilicet Domini nostri Jesu Christi sanctum Evangelium observare vivendo in obedientia, sine proprio et in

101 Regula non bullata, capítulo 1, 2-5. MENESTÒ, Enrico \& BRUFANI, Stefano. Fontes Franciscani..., pp.185 e186.

${ }_{102}$ Regula non bullata, c. 17, 1 e Regula bullata, c. 9, 2. MENESTÒ, Enrico \& BRUFANI, Stefano. Fontes Franciscani..., pp. 200 e 178, respectivamente. 
castitate $^{103 ",}$, diferença bem significativa do ponto de vista retórico. Com a Regra de 1223, o movimento Franciscano adquiriu um nome definido, são "Frades menores", menor no sentido adjetivo comparativo de "parvus", pequeno, humilde, um distanciamento em relação a fraternitas. $O$ nome Minorum Fratrum apareceu pela primeira vez numa carta de 1216 do teólogo francês Jacques de Vitry (c.1160-1240), ele mencionou que "muitos indivíduos de ambos os sexos, ricos e seculares, deixadas todas as coisas por Cristo, fugiam do século, e eram chamados de fratres Minores e sorores Minores", também a bula Pro dilectis de 29 de maio de 1220 de Honório III menciona as palavras Fratres Minores.

Outro trecho relevante é "et Domini nostri Jesu Christi doctrinam et vestigia sequi"; modifica-se para "scilicet Domini nostri Jesu Christi sanctum Evangelium observare"; uma mudança sutilmente jurídica da norma, do verbo sequor para observare; o significado do primeiro é seguir e do segundo é, logo se vê, evidentemente, observar. Aos poucos, por meio da análise comparativa das frases percebemos que a tradução do latim das palavras empregadas nas Regras já constitui complexidade e dificuldade interpretativa.

No segundo capítulo,intitulado "De his qui volunt vitam istam accipere, et qualiter recipi debeant" deparamos com duas alterações que denotam modificações práticas devido ao aumento do número de candidatos e da preocupação por parte da Igreja com as heresias; fica explicíto que os frades deviam respeitar ortodoxia/sacramentos e o recrutamento de novos membros deveria ser mais seletivo e restrito. No trecho inicial do capítulo II da Regra não bulada: "Si quis divina inspiratione volens accipere hanc vitam venerit ad nostros fratres, benigne recipiatur ab eis. Quodsi fuerit firmus accipere vitam nostram, multum caveant sibi fratres, ne de suis temporabilus negotiis se intromittant, sed ad suum ministrum, quam citius possunt, eum repraesentent. Minister vero benigne ispsum recipiat et confortet et vitae nostrae tenorem sibi diligenter exponat", na Regra bulada transforma-se em "Si qui voluerint hanc vitam accipere et venerint ad fratres nostros, mittant eos ad suos ministros provinciales, quibus solummodo et non aliis recipiendi fratres licentia concedatur. Ministri vero diligenter examinent eos de fide catholica et

${ }^{103}$ Cf. Regula non bullata, c.1, 1-2 e Regula bullata, c. 1, 1-2. IDEM, ibidem, pp. 185, 186, 171 e 172, respectivamente. 
ecclesiasticis sacramentis" ${ }^{104}$, mudança jurídica tênue mas, tendo em vista os movimentos populares do período, era significativo o exame da fé católica e do conhecimento dos sacramentos dos candidatos à Ordem dos Frades menores. Como vimos, para entrar no movimento Franciscano bastava ter a divina inspiração e procurar os irmãos que o encaminhariam ao ministro, que receberia o candidato benignamente; mas, com uma norma mais precisa, o segundo texto informa a necessidade de procurar os ministros provinciais que eram os únicos que tinham a permissão de admitir novos membros de acordo com os critérios jurídicos da Igreja.

Ainda no segundo capítulo, os hábitos eram concedidos depois de um ano de provação, seguindo a recomendação da bula Cum secundum, de 22 de setembro de 1220, de Honório II: "Et cum reversus fuerit, minister concedat ei pannos probationis usque ad annum, scilicet duas tunicas sine caputio et cingulum et braccas et caparonem usque ad cingulum. Finito vero anno et termino probationis recipiatur ad obedientiam. Postea non licebit ei ad aliam religionem accedere neque extra obedientiam evagari iuxta mandatum domini papae...", na Regra bulada a mesma recomendação foi reescrita da seguinte maneira: "Postea concedant eis pannos probationis, videlicet duas tunicas sine caputio et cingulum, et braccas et caparonem usque ad cingulum, nisi eisdem ministris aliud secundum Deum aliquando videatur. Finito vero anno probationis, recipiantur ad obedientiam promittentes vitam istam semper et regulam observare. Et nullo modo licebit eis de ista religione exire iuxta mandatum domini papae..."105, A introdução de "prescrição segundo o senhor papa" nas Regras revela um sentido organizacional do movimento que contava com uma participação maior de clérigos na sua redação; observamos também uma medida normativa da Igreja para coibir a saída dos frades da Ordem religiosa em que entravam, mudança não muito significativa do verbo evagari para exire.

No entanto, já a vestimenta dos frades perpassava pela questão da pobreza prática, assunto de constante tensões entre os frades e as Constituições papais, mas é importante enfatizar antes de tudo que o hábito

${ }^{104}$ Regula non bullata, c. 2, 1-3 e Regula bullata c. 2, 2-3. MENESTÓ, Fontes franciscani..., pp. 186 e 172, respectivamente.

${ }^{105}$ Regula non bullata c. 2, 8-10 e Regula bullata c. 2, 10-13. MENESTÓ, Fontes franciscani..., pp. 187 e 173, respectivamente. 
representava um poder, um pertencimento a uma Ordem que estava em plena expansão; assim, o hábito dava prestígio social: "Et omnes fratres vilibus vestibus induantur, et possint eas repeciare de saccis et aliis peciis cum benedictione Dei; quia dicit Dominus in evangelio: Qui in veste pretiosa sunt et in deliciis et qui mollibus vestiuntur, in domibus regum sunt. Et licet dicantur hypocritae, non tamen cessent bene facere nec quaerant caras vestes in hoc saeculo, ut possint habere vestimentum in regno caelorum.", o mesmo excerto é alterado para "Et fratres omnes vestimentis vilibus induantur et possint ea repeciare de saccis et aliis peciis cum benedictione Dei. Quos moneo et exhortor, ne despiciant neque iudicent homines, quos vident mollibus vestimentis et coloratis indutos, uti cibis et potibus delicatis, sed magis unusquisque iudicet et despiciat semetipsum ${ }^{106 " . ~}$. O hábito pobre da fraternitas despertava a atenção nas cidades daquela sociedade; cada vez mais os frades ficavam conhecidos e respeitados, por isso era necessário que se precavesse contra um julgamento temerário em relação aos que não o vestiam. Como já explicitamos, a palavra hypocritae desaparece porque o novo texto demonstra um aumento de importância da nova Ordem; se antes poderia haver a vergonha de usar um hábito pobre, agora, na Regra de 1223, poderia ocorrer o contrário: ao invés da necessidade de encorajamento mudou-se o discurso retórico para a tentação do orgulho; então as seguintes recomendações faziam mais sentido: os frades deveriam respeitar a hierarquia social, não provocando críticas aos ricos e nem às autoridades eclesiásticas locais.

No capítulo terceiro da Regra bulada, com o subtítulo "De divino officio et ieiunio, et quomodo fratres debeant ire per mundum", as modificações são juridicamente mais significativas, possivelmente manifesta-se a intervenção do cardeal protetor Hugolino (futuro Gregório IX). A Regra de 1221 apresenta "Clerici faciant officium et dicant pro vivis et pro mortuis secundum consuetudinem clericorum... Et libros tantum necessarios ad implendum eorum officium possint habere. Et laicis etiam scientibus legere psalterium liceat eis habere illud. Aliis vero nescientibus litteras librum habere non liceat...", na Regra de 1223 houve uma definitiva separação entre os clérigos e leigos na norma: "Clerici faciant divinum officium secundum ordinem sanctae Romanae

${ }^{106}$ Regula non bullata c. 2, 14-15 e Regula bullata c. 2,17-18. IDEM, ibidem. 
Ecclesiae excepto psalterio, ex quo habere poterunt breviaria. Laici vero dicant viginti quatuor Pater noster..."107, acrescentou-se o termo segundo a Igreja Romana para reforçar que ofício divino deveria ser o indicado pela Cúria Romana, mas o saltério poderia ser diferente daquele indicado pela Igreja, enquanto na Igreja de Roma os clérigos seguiam o saltério romano, em outras igrejas particulares seguia-se o saltério galicano. Segundo Desbonnets, 0 termo "Romanae Ecclesiae" denotava seguir os clérigos da Igreja Romana, segundo os capelães da Corte papal e o Corpus Juris Canonici como nos apontava o franciscano van Dijk (melhor conhecedor da liturgia desta época conforme Desbonnets). O IV Concílio de Latrão de 1215 colocou de forma objetiva a separação entre os clérigos e leigos que aqui foram incorporados pela Regra de 1223.

Contudo, na Regra não bulada todos os irmãos poderiam dizer o ofício divino desde que soubessem lê-los; os clérigos o fariam segundo o costume dos clérigos e poderiam ter os livros necessários para isso; os leigos que soubessem ler, também, os leigos que não sabiam ler diriam um ofício composto essencialmente de Pais-nossos. Assim, o ofício divino era acessível a todos, desde que soubessem ler; não se tratava de uma definição canônica (clérigos-leigos), mas de uma diferenciação cultural (os que sabem ler e os que não sabem ler); isso se modifica, e é estabelecida uma diferenciação canônica entre clérigos e leigos, transformação bem significativa e diferente do projeto primitivo, onde se lia "Propter hoc omnes fratres sive clerici sive laici faciant divinum officium, laudes et orationes, secundum quod debent facere" para "Laici vero dicant viginti quatuor Pater noster pro matutino, pro laude quinque, pro prima, tertia, sexta, nona, pro qualibet istarum septem, pro vesperis autem duodecim, pro completorio semptem..."108, transformou-se em uma clara separação entre os clérigos e leigos, o que cada um poderia rezar, uma distinção jurídica institucional prática. Em resumo, os leigos não poderiam mais dizer o ofício dos clérigos, quando soubessem ler. Contudo, não é somente na Regula bullata que aparece esta divisão; no Testamento, aparece a distinção de clérigos-leigos presente da seguinte forma, "Officium dicebamus clerici

\footnotetext{
${ }^{107}$ Regula non bullata c. 3, 4, 7-9 e Regula bullata c. 3,2-4. IDEM, Ibidem, pp. 187 e 188, 174, respectivamente.

${ }_{108}$ Regula non bullata c. 3, 3 e Regula bullata c. 3, 4. MENESTÓ, Fontes franciscani..., pp. 187 e 174, respectivamente.
} 
secundum alios clericos, laici dicebant: Pater noster; et satis libenter manebamus in ecclesiis. Et eramus idiotae et subditi omnibus." ${ }^{109}$. Assim, os clérigos rezavam de acordo com os costumes dos clérigos e os leigos só rezavam o Pai-nosso. Apesar da separação, a Regra Apostólica foi o único modelo do período que colocou os leigos no texto redacional definitivo; a presença dos leigos referiu-se à própria formação do movimento que tinha desde o início uma presença marcante de leigos. Obviamente, a estrutura do ofício dos leigos era simplificada e a dos clérigos, segundo a ordem da Santa Igreja Romana, era mais complexa, inclusive o saltério, que na fórmula pouco clara do "ex quo poterunt habere breviaria" criou discussões tensas entre os frades a partir de 1230. Temos aqui novamente um problema de tradução, porque o verbo habere poderia significar ter, possuir, conservar ou trazer breviários.

Como vemos, a Regra Apostólica foi um projeto redacional muito conciso e preciso, porém um tanto dúbio, principalmente nas definições sobre a pobreza. Mas ter breviários era permitido; o problema consistia em que tipo de breviários os frades poderiam usufruir, visto que eram objetos de alto custo, veremos no segundo capítulo que ora a decisão ficava a cargo do ministro geral da Ordem, ora a decisão se descentralizava para os ministros provinciais, isso quando alguns conventos decidiam através de um procurador; além de tudo havia uma autonomia um pouco indefinida dos conventos mais isolados.

Para Desbonnets, a palavra "ex quo poterunt habere breviaria" podem ter três significações. Na primeira, adotada pelos frades em 1241, subentendida como tempore (na ocasião própria, a tempo), a tradução da frase seria "dirão o ofício segundo a ordem da Igreja Romana, desde que possam ter breviários". O segundo sentido subtenderia ofício: "dirão o ofício segundo a ordem da Igreja Romana, de cujo ofício poderão ter breviários", adotado por Hugo de Digne, João Pechan e Angelo Clareno ${ }^{110}$, os principais comentadores da regra. Contudo, um terceiro sentido seria ainda "os frades devem dizer o ofício segundo a ordem da Cúria, porque (fato que, pelo que) podem ter breviários", para van Dijk este seria o único possível e mais coerente. A norma

\footnotetext{
${ }^{109}$ Testamentum, 18-19. IDEM, ibidem, p. 229.

${ }^{110}$ No capítulo três desta dissertação analisamos os Comentários à Regra franciscana de frei Angelo Clareno (c.1245-1337), como exemplo de um representante dos frades da Marca de Ancona, figura importante e polêmica na Ordem dos Frades menores no início do século XIV.
} 
não é clara, porque provavelmente a intenção daquele que a introduziu na Regra não era simples; talvez signifique que os frades poderiam ter breviários caros apesar de seu voto de pobreza. Como vimos, a tradução das fontes representa um problema complexo e indispensável para entendermos as desavenças internas da interpretação da Regra e Testamento dentro da Ordem após a morte de Francisco e também a interferência na interpretação da norma pela Santa Sé. É claro que não analisaremos palavra por palavra das nossas fontes porque é um assunto inesgotável, e sim somente a seleção de alguns trechos para entendermos a discussão jurídica em torno da pobreza.

Desbonnets, citando a conclusão de Van Dijk, apresenta-nos palavras conclusivas a respeito do trecho que comentamos.

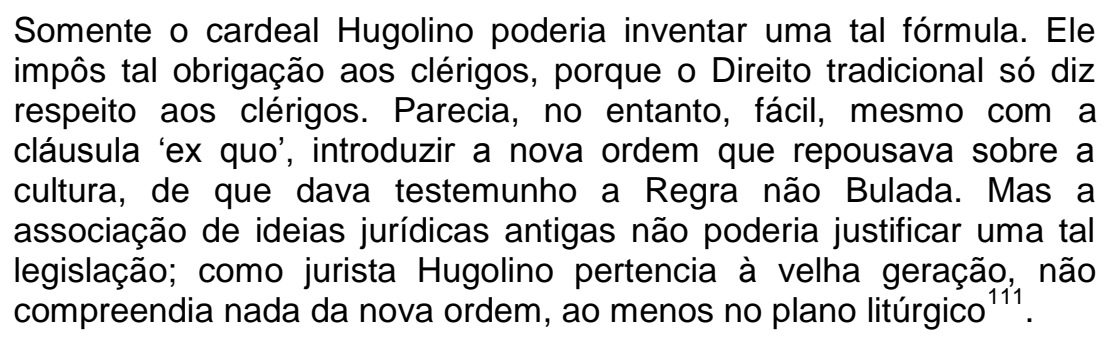

Portanto, as modificações do texto da Regra não bulada levadas para a bulada no capítulo terceiro representam "provas" precisas da influência da Cúria Romana através do cardeal protetor na redação. Com a Reforma Pontifical, a separação litúrgica dos clérigos e leigos representavam uma diferença significativa da fraternitas primitiva para a institucionalização da Ordem. A interferência da Igreja não visava a alterar o espírito franciscano como apregoa uma historiografia marxista combativa, mas enquadrá-lo nos moldes das instituições monásticas tradicionais, preservando-lhe as características específicas que sofreriam metamorfoses ao longo da construção normativa para a adaptação de acordo com o Corpus Juris canonici. O problema jurídico aqui foi a adaptação de um movimento popular e seu adequamento aos padrões legislativos da lgreja medieval. A pobreza só poderia ser aquela que era comum aos outros grupos religiosos que estavam dentro da ortodoxia. Uma das consequências disso tudo era a pobreza prática abortada em quase todos os momentos, para uma pobreza cada vez mais

${ }^{111}$ DESBONNETS, T. Op. cit., p. 101. 
restrita ao plano teórico e centralizada na instituição; por isso tantas tensões na interpretação da norma se iniciavam.

O quarto capítulo, de título "quod fratres non recipiant pecuniam", é um capítulo mais conciso e enxuto que o oitavo capítulo da Regra não bulada, porque as citações bíblicas são suprimidas, bem como os versículos oitavo, nono e décimo. De "Et nullo modo fratres recipiant nec recipi faciant nec quaerant nec quaeri faciant pecuniam pro eleemosyna neque denarios pro aliquibus domibus vel locis; neque cum persona pro talibus locis pecunias vel denarios quaerente vadant; alia autem servitia, quae non sunt contraria vitae nostrae, possunt fratres locis facere cum benedictione Dei. Fratres tamen in manifesta necessitate leprosorum possunt pro eis, quaerere eleemosynam..." a doutrina é a mesma agrupada na bulada somente num único paragráfo: "Praecipio firmiter fratribus universis, ut nullo modo denarios vel pecuniam recipiant per se vel per interpositam personam. Tamen pro necessitatibus infirmorum et aliis fratribus induendis, per amicos spirituales, ministri tantum et custodes sollicitam curam gerant secundum loca et tempora et frigidas regiones, sicut necessitati viderint expedire; eo semper salvo, ut, sicut dictum est, denarios vel pecuniam non recipiant." ${ }^{112}$. Na primeira Regra os versículos são difíceis de traduzir, especialmente a palavra eleemosyna, que aparece duas vezes com diferentes significações. Em resumo, os três versículos formam um conjunto, comprovado pelo último que concede uma autorização, em oposição às proibições dos versículos anteriores.

Conforme Desbonnets, as palavras autorização e proibição remetem a um mesmo contexto, os leprosos. Já as casas e lugares do versículo oitavo, nos quais, segundo o versículo nono, os frades podem servir são, pois, os leprosários. Ele observa que os três "pro" do versículo oitavo, "pro eleemosyna", "pro aliquibus domibus vel locis", "pro talibus locis", são perfeitamente paralelos, donde concluímos que, nestas expressões, "eleemosyna" (do grego esmola) designa também um lugar. Nos glossários medievais, entre os diversos sentidos desta palavra, todos derivados da ideia de piedade, assinalam o sentido "asilo de pobres".

\footnotetext{
${ }^{112}$ Regula non bullata c. 8, 8-10 e Regula bullata c. 4, 2-4. MENESTÓ, Fontes franciscani..., pp. 193 e 175, respectivamente.
} 
Como já foi mencionado, a supressão dos três versículos demonstra um sinal de profundo desenvolvimento da norma e a maneira de viver dos frades. Nos primeiros tempos, viviam próximo aos leprosários e neles trabalhavam (realidade mais próxima da Regra não bulada), episódio não confirmado pelo Testamento que menciona igrejas, mas pelas hagiografias de Celano e Boaventura. No entanto, a partir do momento em que os frades não mais moravam nos arrebaldes dos leprosários e não mais executavam seu trabalho ali, tais recomendações não tinham mais sentido (realidade mais próxima da Regra bulada), por isso a modificação. Antes, o movimento franciscano era itinerante, non stabilitas loci, não havia conventos ou lugares fixos; com a Regra definitiva, estabeleceram-se lugares fixos e conventos de propriedade da Ordem, que depois passaram juridicamente para a Igreja Romana a partir da bula Quo elongati de Gregório IX.

No quinto capítulo, intitulado "De modo laborand", é perceptível o aperfeiçoamento normativo referente ao recrutamento de candidatos. Antes, o movimento recebia candidatos de diferentes seguimentos sociais, sem nenhuma seleção ou critérios, bastava a vontade de se despojar dos bens e viver na pobreza, como explicitamos no início deste capítulo. Na época da redação da Regra de 1223 os clérigos não correspondiam mais às exceções;agora tornaram-se a maioria dentro do movimento Franciscano; o texto mudou para: "Fratres illi, quibus gratiam dedit Dominus laborandi, laborent fideliter et devote, ita quod, excluso otio animae inimico, sanctae orationis et devotionis spiritum non exstinguant, cui debent cetera temporalia deservire. De mercede vero laboris pro se et suis fratribus corporis necessaria recipiant praeter denarios vel pecuniam et hoc humiliter, sicut decet servos Dei et paupertatis sanctissimae sectatores." ${ }^{113}$. Na Regra não Bulada, no capítulo sétimo, o mesmo trecho aparecia da seguinte forma: "Et fratres, qui sciunt laborare, laborent et eandem artem exerceant, quam noverint, si non fuerit contra salutem animae et honeste poterit operari [...] Et pro labore possint recipere omnia necessaria praeter pecuniam. Et cum necesse fuerit, vadant pro eleemosynis sicut alii pauperes. Et liceat eis habere ferramenta et instrumenta suis artibus opportuna... Et iterum: Otiositas inimica est animae."114, assim, o

\footnotetext{
${ }_{113}^{113}$ Regula bullata, c. 5, 2-5. IDEM, ibidem, pp. 175 e 176.

${ }^{114}$ Regula non bullata, c. 7, 3,7-9,11. IDEM, ibidem, pp. 191 e 192.
} 
texto manifestava maior apreço pelo trabalho manual, cada um continuava exercendo seu ofício manual que havia aprendido, conservando inclusive a propriedade de seus instrumentos de trabalho, ou aquele que não conhecia uma profissão engajava-se para "servir" em casas dos outros. Já a frase da Regra bulada: "Fratres illi, quibus gratiam dedit Dominus laborandi, laborent fideliter et devote", trata-se do trabalho manual partindo do princípio da Regra beneditina do ócio como inimigo da alma, na qual os frades poderiam receber pelo trabalho executado, exceto dinheiro; mas, efetivamente, já não correspondia mais à realidade da Regra bulada, porque os clérigos passaram a ser a maioria, o que sabiam fazer era pregar, não tinham mais necessidade de instrumentos para tal, por isso um texto mais enxuto e preciso para uma Ordo clericorum. O exceto "pecuniam" configurou-se na especificidade da normativa franciscana que tinha como princípio a pobreza e a renúncia aos bens materiais; os frades eram proibidos de lidar diretamente com dinheiro e propriedades. Veremos mais adiante que isso provocou, consequentemente, uma série de tensões na Ordem e a promulgação das constituições papais.

De forma mais breve, no capítulo sexto da Regra de 1223, intitulado "Quod nihil approprient sibi fratres, et de eleemosyna petenda et de fratribus infirmis" suscita-nos uma modificação textual importante a frase que congelouse em: "Et, si quis eorum in infirmitate ceciderit, alii fratres debent ei servire, sicut vellent sibi serviri" ${ }^{115}$; antes esta mesma recomendação estava localizada no capítulo X da Regra de 1221 intitulado "De infirmis fratribus" da seguinte forma: "Si quis fratrum in infirmitate ceciderit, ubicumque fuerit, alii fratres non dimittant eum, nisi constituatur unus de fratribus vel plures, si necesse fuerit, qui serviant ei, sicut vellent sibi serviri; sed in maxima necessitate possunt ipsum dimittere alicui personae quae suae debeat satisfacere infirmitati" ${ }^{116}$. Na Regra Bulada, a vida dos frades era outra; os frades habitavam em conventos, um lugar fixo, portanto quem adoecesse seria cuidado por outro frade do mesmo local. Durante o período de redação da Regra não bulada, os frades via de regra viviam nas estradas em missões pregando a penitência, onde se encontrassem, e, caso algum adoecesse, deveriam ajudá-lo, um problema que nem sempre se sabia como resolver em terras distantes da Península italiana.

\footnotetext{
${ }^{115}$ Regula bullata, c. 6, 10. IDEM, ibidem, p. 176.

${ }^{116}$ Regula non bullata, c. 10, 1-2. IDEM, ibidem, p. 195.
} 
Por este motivo, possivelmente o texto da Bulada é mais breve. A Ordem já possuia conventos, lugares fixos com uma hierarquia centralizada no ministro geral, cardeal protetor (o representante da Igreja na Ordem), ministros provinciais, custódios, entre outros; assim, em todos os aspectos, a organização da Ordem franciscana já se diferenciavai bastante dos primeiros tempos, não porque havia mudado o espírito do movimento, mas porque a mudança normativa era devida às circunstâncias exteriores, muitas vezes fruto do crescimento do número de frades e de interferências jurídicas da Cúria Romana que tinha por objetivo adequar a nova Regra aos padrões canônicos eclesiásticos.

O capítulo sétimo, intitulado "De poenitentia ratribus peccantibus imponenda", deve ser comparado aos capítulos cinco e vinte da Regra não Bulada. A questão dos pecados torna-se mais rígida, principalmente após o IV Concílio de Latrão de 1215. Da noção subjetiva de foro íntimo do trecho: "Si vero inter fratres ubicumque fuerit aliquis frater volens carnaliter et non spiritualiter ambulare, fratres, cum quibus est, moneant eum, instruant et corripiant humiliter et diligenter. Quod si ille post tertiam admonitionem noluerit se emendare, quam citius possunt, mittant eum vel significent suo ministro et servo, qui minister et servus de eo faciat sicut sibi secundum Deum melius videbitur expedire"117, passa-se para uma noção mais objetiva e de foro externo, "Si qui fratrum, instigante inimico, mortaliter peccaverint, pro illis peccatis, de quibus ordinatum fuerit inter fratres, ut recurratur ad solos ministros provinciales, teneantur praedicti fratres ad eos recurrere quam citius poterint, sine mora. Ipsi vero ministri, si presbyteri sunt, cum misericordia iniungant illis poenitentiam; si vero presbyteri non sunt, iniungi faciant per alios sacerdotes ordinis, sicut eis secundum Deum melius videbitur expedire..."118; os pecados passaram a cargo da absolvição reservada somente aos ministros provinciais. Além disso, a supressão total do trecho da Regra não bulada, "Si quis autem ministrorum alicui fratrum aliquid contra vitam nostram praeciperet vel contra animam suam, non teneatur ei obedire; quia illa obedientia non est, in qua delictum vel peccatum committitur." ${ }^{119}$, que suscitaria a desobediência aos

\footnotetext{
${ }^{117}$ Regula non bullata, c. 5, 5-6. IDEM, ibidem, pp. 189 e 190.

${ }_{118}$ Regula bullata, c. 7, 2-3. IDEM, ibidem, pp. 177.

${ }^{119}$ Regula non bullata, c. 5, 2. IDEM, ibidem, pp. 189.
} 
ministros, o que juridicamente tornaria um problema mais adiante para a Ordem, explica a sua extinção. Assim como outro trecho problemático em relação à confissão e suprimido estava localizado no capítulo $X X$ da não bulada: "Et si non potuerint, confiteantur aliis discretis et catholicis sacerdotibus scientes firmiter et attendentes, quia a quibuscumque sacerdotibus catholicis acceperint poenitentiam et absolutionem, absoluti erunt procul dubio ab illis peccatis, si poenitentiam sibi iniunctam procuraverint humiliter et fideliter observare. Si vero tunc non potuerint habere sacerdotem, confiteantur fratri suo, sicut dicit apostolus Jacobus: Confitemini alterutrum peccata vestra. Non tamen propter hoc dimittant recurrere ad sacerdotem, quia potestas ligandi et solvendi solis sacerdotibus est concessa." ${ }^{20}$, mais tarde poderia consolidar uma prática de confissão individual a um frade ao invés de se recorrer aos ministros provinciais que tinham o encargo exclusivo da absolvição.

Já o capítulo oitavo "De electione generalis ministri huius fraternitatis et de capitulo Pentecostes" ${ }^{121}$, em grande parte novo se comparado à Regra de 1221, trouxe a regulamentação de uma questão que não foi abordada anteriormente: a criação de uma hierarquia dentro da nova Ordem e a criação do ministro geral da fraternidade e os ministros provinciais, "Universi fratres unum de fratribus istius religionis teneantur semper habere generalem ministrum et servum totius fraternitatis et ei teneantur firmiter obedire." ${ }^{122}$. Mais adiante, subentendemos que era um cargo vitalício; a não ser que o ministro geral não fosse mais adequado ou não desse conta do serviço para o cargo, poderia ser deposto ${ }^{123}$. O ministro geral deveria ser eleito pelos ministros provinciais e custódios reunidos no Capítulo de Pentecostes conforme a norma das eleições: "Quo decedente, electio successoris fiat a ministris provincialibus

\footnotetext{
${ }^{120}$ Regula non bullata, c. 20, 2-4. IDEM, ibidem, pp. 203.

121 Os encontros gerais dos frades se sucediam a cada três anos, geralmente convocado pelo ministro geral e os ministros provinciais obrigatoriamente participavam. Os Capítulos gerais dos frades dos séculos XIII e XIV ainda não foram muito bem esclarecidos pela historiografia, não há dados precisos nas pesquisas em relação a esses encontros e muito menos sobre as discussões abordadas.

${ }_{122}$ Regula bullata, c. 8, 2. MENESTÓ, Fontes franciscani..., pp. 177 e 178.

123 Segundo a Legenda dos Três Companheiros, um bom exemplo de ministro geral não muito adequado para o cargo foi Elias de Cortona (c.1180-1253), acusado de arrecadar dinheiro em demasia para a construção da Basílica de Assis e de ações de grave perturbação no ato de transladação do corpo do Santo. Apesar da tradição, a bula Speravimus hactenus isentava os frades de qualquer acusação e suspeita, confirmando que os Menores dependiam da vontade e projetos de Gregório IX. Elias foi eleito como ministro geral em 1232 no Capítulo geral de Rieti e deposto em 1239.
} 
et custodibus in capitulo Pentecostes, in quo provinciales ministri teneantur semper insimul convenire, ubicumque a generali ministro fuerit constitutum; et hoc semel in tribus annis vel ad alium terminum maiorem vel minorem, sicut a praedicto ministro fuerit ordinatum. Et si aliquo tempore appareret universitati ministrorum provincialium et custodum, praedictum ministrum non esse sufficientem ad servitium et communem utilitatem fratrum, teneantur praedicti fratres, quibus electio data est, in nomine Domini alium sibi eligere in custodem. Post capitulum vero Pentecostes ministri et custodes possint singuli, si voluerint et eis expedire videbitur, eodem anno in suis custodiis semel fratres suos ad capitulum convocare." ${ }^{124}$. Como vimos nos trechos mencionados, a definição de uma hierarquia específica franciscana está presente somente na Regra de 1223.

De maneira mais enxuta, o capítulo nono, intitulado "De praedicatoribus", com quatro versículos na Regra bulada sobre os pregadores corresponde ao capítulo dezessete com nove versículos da Regra não bulada. Prova disso é o trecho "Omnes tamem frates operibus praedicent" ${ }^{125}$, seguido de uma longa exortação, não adequado a um texto legislativo que desaparece totalmente na Regra de 1223. A tradução pode ser "todos os irmãos pregarão por seus atos", mas a tradução "todos os irmãos pregarão por seus trabalhos" harmoniza-se melhor com o restante do texto que ressalta o trabalho manual, inclusive em casas de outras pessoas, segundo Desbonnets ${ }^{126}$. Na Regula Bullata, o número de frades que viviam em casas de outrem diminuiu muito, enquanto $\mathrm{o}$ dos pregadores aumentaram. Reciprocamente, fez-se necessário não somente assegurar os direitos dos bispos locais em relação à pregação crescente, mas a prévia autorização do ministro geral objetivava um controle maior do que seria pregado ao povo e de obediência à hierarquia. "Fratres non praedicent in episcopatu alicuius episcopi, cum ab eo illis fuerit contradictum. Et nullus fratrum populo penitus audeat praedicare, nisi a ministro generali huius fraternitatis fuerit examinatus et appobatus, et ab eo officium sibi praedicationis concessum. Moneo quoque et exhortor eosdem fratres, ut in praedicatione, quam faciunt, sint examinata et casta eorum eloquia, ad utilitatem et

\footnotetext{
${ }^{124}$ Regula bullata, c. 8, 3-6. IDEM, ibidem, p. 178.

${ }^{125}$ Regula non bullata, c. 17, 3. MENESTÓ, Fontes franciscani..., p. 200.

${ }^{126}$ DESBONNETS, T. Da intuição..., p.103.
} 
aedificationem populi..."127. Devido ao problema recorrente das heresias, a pregação deveria ser examinada e aprovada pelo ministro geral e, principalmente, era concedida somente àqueles que tinham como ofício a pregação numa linguagem examinada e casta. Assim, a pregação ${ }^{128}$ só podia ser de acordo com a ortodoxia da Santa Sé, um dos pontos básicos da norma; por isso a regulamentação e definição dos contornos dessa pregação centralizada nas mãos do ministro geral. Além do mais, um fator essencial para o crescimento rápido da Ordem Franciscana foi a pregação discursiva simples e popular, porque os franciscanos se utilizavam da linguagem comum e vernácula para expor o Evangelho, o que atraia os habitantes das cidades; era dirigida somente ao clero a pregação em latim. Enfim, segundo a normativa, o ato de pregar não poderia ser aleatório e sem conteúdo préestabelecido.

No capítulo décimo "De admonitione et correctione fratrum" da Bulada, notamos o desaparecimento das frases do capítulo cinco da Regra sem bula, "Si quis autem ministrorum alicui fratrum aliquid contra vitam nostram praeciperet vel contra animam suam, non teneatur ei obedire; quia illa obedientia non est, in qua delictum vel peccatum committitur..." e "Similiter omnes fratres non habeant in hoc potestatem vel dominationem maxime inter $s{ }^{\text {"129 }}$. Notamos também o desaparecimento dos seguintes excertos do capítulo seis da Regra não bulada: "Frates, in quibuscumque locis sunt, si non possunt vitam nostram observare, quam citius possunt, recurrant ad suum ministrum hoc sibi significantes. [...] Et nullus vocetur prior, sed generaliter omnes

\footnotetext{
${ }^{127}$ Regula bullata, c. 9, 2-4. IDEM, ibidem, p. 178.

${ }^{128}$ Uma observação importante em relação ao papa Inocêncio III (1198-1216) que no IV Concílio de Latrão de 1215 instituiu o décimo cânone De praedicatoribus instituendis definindo - modo que a Igreja deveria proceder para aumentar a eficácia da pregação e combater as heresias. Seu grande objetivo era o de combater os desvios (heresia), estimulando a fé católica (ortodoxia), se bem que os limites eram bastante tênues e ambos conceitos são difíceis de definir de maneira absoluta. Entretanto, vale ressaltar que conforme André Vauchez, o tempo de pregação coincide com o tempo da inquisição e segundo Paul Sabatier, o século XIII é por excelência o século dos santos e dos heréticos, ao mesmo tempo, havia a canonização e a condenação numa proporção quase que igualitária. "Os conservadores de nossa época, que fazem apelo ao século XIII como a idade de ouro da fé autoritária, cometem um estranho erro: se aquele é, por excelência, o século dos santos, é também o dos hereges. Veremos, a seu tempo, que essas duas palavras não são tão contraditórias como parecerem. Para o momento, basta notar que jamais a Igreja foi tão poderosa nem tão ameaçada.". SABATIER, Paul. Op. cit., p. 22.

${ }^{129}$ Regula non bullata, c. 5, 2 e 9. MENESTÓ, Fontes franciscani..., pp. 189 e 190, respectivamente.
} 
vocentur fratres minores. Et alter alterius lavet pedes (cfr. loa 13, 14)."130. Trechos conflitantes em relação ao todo e à hierarquia estabelecida, por isso a sua eliminação pela Cúria Romana foi conveniente e proposital, pois poderia promover a desobediência, e sem a obediência nenhuma Ordem religiosa se mantém. Ademais, o trecho "non possunt vitam nostram observare" transformase na bulada em "se non posse regulam spiritualiter observare, ad suos ministros debeant et possint recurrere", de nossa vida para nossa Regra; neste curto capítulo a palavra Regra aparece três vezes, da seguinte forma: uma vez como "não podem observar espiritualmente a Regra" e duas vezes como "a nossa Regra".

Sem dúvida, com palavras mais diretas e concisas, o capítulo undécimo da Regra bulada intitulado "Quod fratres non ingrediantur monasteria monacharum" atesta-nos o desenvolvimento do movimento feminino Franciscano representado pelas "Pobres Damas" e limita as iniciativas dos frades, que só deveriam entrar em contato com elas se obtivessem licença especial emitida pela Santa Sé. Com verbo na primeira pessoa do singular o excerto: "Praecipio firmiter fratribus universis, ne habeant suspecta consortia vel consilia mulierum, et ne ingrediantur monasteria monacharum praeter illos, quibus a sede apostolica concessa est licentia specialis; nec fiant compatres virorum vel mulierum nec hac occasione inter fratres vel de fratribus scandalum oriatur" ${ }^{131}$. Assim, notamos que é retomado o essencial do capítulo doze "De malo visu et frequentia mulierum" da Regula sine bula, entretanto o que é eliminado é muito significativo, como o trecho "Et nullus cum eis consilietur aut per viam vadat solus aut ad mensam in una paropside comedat. Sacerdotes honeste loquantur cum eis dando poenitentiam vel aliud spirituale consilium. Et nulla penitus mulier ab aliquo fratre recipiatur ad obedientiam, sed dato sibi consilio spirituali, ubi voluerit agat poenitentiam Et multum omnes nos custodiamus et omnia membra nostra munda teneamu, quia dicit Dominus: Qui viderit mulierem ad concupiscendam eam, iam moechatus est eam in corde suo (Mat 5,28)." ${ }^{132}$; os frades deviam limitar-se a dar um "conselho espiritual" às mulheres, que teriam de escolher pessoalmente os caminhos da penitência,

\footnotetext{
${ }^{130}$ Regula non bullata, c. 6, 1 e 3-4. MENESTÓ, Fontes franciscani..., p. 191.

131 Regula bullata, c. 11, 2-4. IDEM, ibidem, p. 180.

132 Regula non bullata, c. 12, 2-5. IDEM, ibidem, p. 197.
} 
sem qualquer relacionamento com os Menores. No entanto, a interdição de viajar sozinho com uma mulher ou de tomar refeição na companhia dela ou de recebê-la à obediência, são proibições que ecoam uma época anterior em que os frades andavam, sobretudo, pelos caminhos, pelas estradas ou nos leprosários na companhia de mulheres, mas que já não fazia mais sentido para a Regra bulada. De caráter canônico, a referência às mulheres na bulada é diferente, pois leva os frades a assumir a cura animarum e o tradicional papel de visitadores dos mosteiros femininos, principalmente das "Irmãs pobres" em São Damião ${ }^{133}$. A cura animarum configurava um encargo oneroso, porque a Ordem masculina ficava com a responsabilidade inclusive econômica de sustentação do mosteiro feminino, responsabilidade espiritual, material, etc.

No capítulo duodécimo, nomeado "De euntibus inter saracenos et alios infideles" atentamos que desaparece a maior parte das citações bíblicas e somente os dois primeiros versículos correspondem ao título do capítulo. $\mathrm{Na}$ Regra não bulada situa-se no capítulo dezesseis de mesmo título; assim os frades poderiam partir para entre os infiéis com a licença de seu ministro, que não Ihes podia recusar o que Ihes parecesse adequado. Entretanto, na Regra bulada, os frades podiam partir com a licença de seu ministro, desde que o ministro não a concedesse aos que não preenchessem as condições necessárias. Consideramos uma sútil modificação de "Unde quicumque frater voluerit ire inter saracenos et alios infideles, vadat de licentia sui ministri et servi. Et minister det eis licentiam et non contradicat, si viderit eos idoneos ad mittendum; nam tenebitur Domino reddere rationem (cfr. Lc 16,2), si in hoc vel in aliis processerit indiscrete."134, já para a Regra Bulada "Quicumque fratrum divina inspiratione voluerint ire inter saracenos et alios infideles petant inde licentiam a suis ministris provincialibus. Ministri vero nullis eundi licentiam tribuant, nisi eis quos viderint esse idoneos ad mittendum." ${ }^{135}$.

\footnotetext{
133 "The bulls (1245) which place German women's houses under the Dominican Order ande the houses of the Order of St. Damian under the Franciscans all share wording: the women are placed sub magisterio et doctrina of the minister general of the order and the provincial in question; they participate in all the privileges granted to the order. The minister general and the provincial are to assume the sollicitudo et cura animarum in the women's houses, either fulfilling the obligations of visitation themselves or through suitable deputies; the free election of the priores or abbess, however, was reserved to the convent itself.". GRUNDMANN, Herbert. Op. cit., p. 119.

${ }_{134}^{134}$ Regula non bullata, c. 16, 3-4. IDEM, ibidem, pp. 198 e 199.

${ }^{135}$ Regula bullata, c. 12, 2-3. IDEM, ibidem, p. 180.
} 
O mais significativo é a supressão da quase totalidade do capítulo dezesseis da Regra não bulada que contém uma série de citações bíblicas, que abrangia um conjunto de normas aos frades que se encontravam nas terras dos infiéis, atitudes que poderiam tomar para organizar a sua vida, fruto da experiência dos frades nas missões em diferentes regiões. A seguir as principais passagens bíblicas que não aparecem na Regra de 1223: "Et pro eius amore debent se exponere inimicis tam visibilibus quam invisibilibus; quia dicit Dominus: Qui perdiderit animam suam propter me, salvam faciet (cfr. Luc 9,24) eam in vitam aeternam (Mat 25,46). Beati qui persecutionem patiuntur propter iustitiam, quoniam ipsorum est regnum caelorum (Mat 5,10). Si me persecuti sunt, et vos persequentur (loa 15,20). Et: Si persequuntur vos in uma civitate, fugite in aliam (cfr. Mat 10,23). Beati estis (Mat 5,11), cum vos oderint homines (Luc 6,22) et maledixerint vobis (Mat 5,11) et persequentur vos et separaverint vos et exprobraverint et eiecerint nomen vestrum tamquam malum (Luc 6,22) et cum dixerint omne malum adversum vos mentientes propter me (Mat 5,11). Gaudete in illa die et exsultare (Luc 6,23), quoniam merces vestra multa est in caelis (cfr. Mat 5,12). Et ego dico vobis amicis meis, non terreamini ab his (cfr. Luc 12,4), et nolite timere eos qui occidunt corpus (Mat 10,28) et post hoc non habent amplius quid faciant (Luc 12,4). Videte, ne turbemini (Mat 24,6). In patientia enim vestra possidebitis animas vestras (Luc 21,19) et qui perseveraverit usque in finem, hic salvus erit (Mat 10,22; 24,13)."136. Certamente, a supressão da maior parte do capítulo foi influência da Igreja Romana preocupada com as Cruzadas, com a tomada de Jerusalém e com o combate aos infiéis. Contudo, a descrição do capítulo dezesseis da Regra de 1221, o proceder de modo indiscreto, não litigar e anunciar a palavra de Deus, expor-se aos inimigos e pregar aos infiéis refletem uma novidade da Regra Franciscana. Nenhuma outra Regra religiosa estimulou a pregação aos infiéis de forma a convertê-los ao cristianismo. "Unus modus est, quod non faciant lites neque contentiones, sed sint subditi omni humanae creaturae propter Deum (1Pet 2,13) et confiteantur se esse christianos. Alius modus est, quod, cum viderint placere Domino, annuntient verbum Dei, ut credant Deum omnipotentem, Patrem et Filium et Spiritum Sanctum (cfr. Mat 28, 19),

${ }^{136}$ Regula non bullata c. 16, 11-21. IDEM, ibidem, pp. 199 e 200. 
creatorem omnium, redemptorem et salvatorem Filium, et ut baptizentur et efficiantur christiani, quia quis renatus non fuerit ex aqua et Spiritu Sancto, non potest intrare in regnum Dei (cfr. loa 3,5)."137.

Como vimos, as Regras foram resultado das circunstâncias exteriores, entrada de clérigos na fraternidade e interferências canônicas da Cúria Romana. Cada vez mais a Ordem se expandia. As principais mudanças conforme já explicitamos foram as seguintes: doações de bens móveis como conventos (lugares fixos) e objetos, formação de uma hierarquia específica, desenvolvimento de uma identidade com um nome definido, a adesão de novos membros deveria ser examinada e não poderia mais qualquer pessoa ingressar na Ordem; não bastava apenas ter boa vontade como antes. Além do mais, uma série de requisitos foram reformulados. O hábito franciscano passou a ganhar importância identitária, por isso a recomendação para os frades não se vangloriarem e nem criticarem outrem. Por serem cada vez mais numerosos os sacerdotes na Ordem, os frades passaram a se dedicar à pregação; assim o trabalho manual passou a ter importância menor já que o número de leigos foi diminuindo. Constantemente os frades eram lembrados de respeitarem a hierarquia da Ordem e só pregarem na diocese de um bispo se o mesmo autorizasse. Sobretudo, as mudanças na Regra revelam não só o crescimento do número de frades, bem como a influência do cardeal Hugolino na redação do texto com o intuito de adequar o movimento aos regulamentos jurídicos da Santa Sé.

Discordamos da análise da Regra bulada feita pelo colombiano Fernando Uribe, quanto à divisão dos capítulos da Regra Apostólica, a saber, "O texto original da Regra que se encontra na bula pontíficia aparece dividido em doze capítulos. Sabemos que esta divisão não foi feita por Francisco e que provavelmente foi introduzida de maneira apressada por algum funcionário da Cúria Romana na última hora, pouco antes de sua aprovação, para satisfazer as exigências práticas; trata-se, por outro lado, de um número simbólico, dadas as fortes ressonâncias bíblicas que possui." ${ }^{138}$. Obviamente, a divisão dos capítulos não foi feita por Francisco, no entanto, não foram feitas apenas por

\footnotetext{
${ }^{137}$ Regula non bullata c. 16, 5-7. IDEM, ibidem, pp. 199.

138 Cf. URIBE, Fernando. Apuntes para una lectura actualizada de la Regla Franciscana. Provincia Franciscana de Valencia, Aragón y Baleares: selecciones de Franciscanismo, 2006, volume 36, número 104, pp. 181-206.
} 
motivos práticos e de última hora, mas a intenção era jurídica e de ajustamento institucional. A proposta de Uribe de dividir a Regra bulada numa estrutura temática geral mostra-se pertinente, porém 0 autor defende uma leitura pedagógica do texto, criticando a leitura jurídica das normas, sempre ressaltando a praticidade cotidiana que teria influenciado o texto de 1223. Justifica-se, explicitando que a regra precisava corresponder aos motivos de ordem prática do cotidiano dos frades, por exemplo, jejuns, comida, adoção do saltério "galicano", pregação, trabalho, cuidado dos enfermos, etc. No entanto, foram introduzidos jejuns e orações, entre outros preceitos que nada tinham a ver com a formação do movimento Franciscano.

Apesar disso, Uribe concorda de uma certa maneira com a pesquisa do francês Desbonnets. Na seguinte passagem ele menciona: "nas últimas décadas têm sido feitas várias pesquisas comparativamente com a Regra não bulada, compilada em 1221, nas quais se acentua com um certo dramatismo a passagem violenta da intuição à instituição experimentada pela Ordem em somente dois anos. Não há dúvida de que são pesquisas importantes e ainda necessárias para entender a passagem da fraternitas a Ordo, mas não parece justo apresentá-las como um desmembramento da Regra de 1223, como se esta tivesse sido sufocada no espírito de Francisco. Uma tal apresentação negativa, ainda que seja na forma implícita, é antipedagógica..."139. Certamente, para ambos os autores, o espírito franciscano não foi sufocado mas institucionalizado e adaptado já que a Regra de 1223 é um documento desenvolvido e elaborado, resultado da construção de toda a comunidade dos frades e não apenas de Francisco de Assis.

O projeto primitivo ou intuição teve que se adequar aos preceitos jurídicos do Corpus Juris Canonici. Na verdade, a institucionalização resultou da habilidade da Igreja Católica em incorporar o movimento Franciscano, controlando-o e normatizando-o através do cardeal protetor. Outrora, os movimentos populares penitenciais criticavam a riqueza da Igreja de forma indireta, propondo um retorno à pobreza evangélica e à piedade laica, ideia advinda das reformas do século XII. No entanto, a "efervescência" popular religiosa pululava em toda a cristandande ocidental; chegou um momento em

${ }^{139}$ URIBE, F. Op. cit., pp. 205-206. 
que não se podia continuar somente sufocando, era preciso absorvê-la dentro dos limites da cristandade latina.

Ao oficializar a Ordem Franciscana em 29 de novembro de 1223 com a bula Solet annuere, Honório III (1216-1227) e a Igreja tornaram pública a imitatio Christi e a pobreza franciscana, marcando o segundo momento de enquadramento do movimento Franciscano com a definitiva consolidação da institucionalização.

\begin{abstract}
Onorio vescovo, servo dei servi di Dio, ai diletti figli frate Francesco e agli altri frati dell'Ordine dei frati minori, [invidia] salute e apostolica benedizione. La Sede apostolica è solita accondiscendere benevolmente ai pii voti e agli onesti desideri dei richiedenti. Pertanto, figli diletti nel Signore, noi, inclini alle vostre pie preghiere, confermiamo a voi con l'autorità apostolica la Regola del vostro Ordine, approvata dal nostro predecessore Innocenzo III, di buona memoria, trascritta in questa lettera, e la avvaloriamo con il patrocinio del presente scritto. A nessuno pertanto sia lecito violare in qualsiasi modo questo... ${ }^{40}$
\end{abstract}

Como bem observa André Vauchez em relação à bula de aprovação da Norma, "A bula Solet annuere conferia à Ordem Franciscana a base jurídica que Ihe faltava, preço de um devoto subterfúgio. Ela se apresenta como uma simples confirmação, banal e anedótica do texto que o papa Inocêncio III tinha aprovado em 1209. O papado não queria se colocar em contradição com as medidas postas pelo Concílio de Latrão IV de proibir a criação de novas ordens religiosas [...] A regra que reflete a intenção no programa do Pobre de Assis não é então a Regula bullata de 1223, mas a de 1221, que pode ser considerada como o documento de base ou a Carta da fraternidade."141.

A Solet annuere era a forma mais seca possível e sem comprometer 0 papa Honório III. Simplesmente aprovou um ato interno da Ordem; na verdade, renovou uma aprovação anterior, ato que não conferia nenhuma importância eclesial significativa. Talvez revelasse uma estratégia ou traduzisse o desejo de não favorecer uma situação que parecia ainda explosiva no interior da Ordem. A hipótese de Desbonnets seria de que Francisco nada havia pedido a Santa

\footnotetext{
${ }^{140}$ Com essa bula, a Regra dos Frades menores ficou conhecida como "Regra bulada", por oposição à Regra de 1221, conhecida como "Regra não bulada". Assim, a Regra de 1223 configurou-se numa reformulação de acordo com uma série de preceitos jurídicos propriamente normativos. "Bolla Solet annuere di Onorio III". In: CAROLI, Ernesto (org.) Fonti Francescane, nuova edizione...., p. 1712.

${ }^{141}$ VAUCHEZ, André. Op. cit., p. 170.
} 
Sé, e sim os seus ministros e o cardeal Hugolino e, para não assustar Francisco, que rejeitaria uma carta solene, havia sido escolhido um formulário mais banal. Além disso, conforme Bartoli-Langeli, as relações entre Francisco e a Cúria romana não foram objetivamente relacionamentos difíceis; não era uma questão ligada a atitudes pessoais, mas o encontro de duas concepções ambas motivadas por um sentido muito elevado de responsabilidade em relação ao movimento Franciscano.

Enfim, Desbonnets sintetiza com uma citação de A. Bartoli-Langeli: "A Solet annuere disfarçou a Quo elongati e liquidou a convicção de Francisco de que sua fraternidade se fizesse forte sob a proteção papal."142. Contudo, é necessário perguntar porque o papa Honório III utilizou o modelo da Carta Solet annuere para aprovar a Regra dos Frades menores. Geralmente a Solet annuere era um formulário para assuntos menos importantes. O primeiro exemplar data de 1198, não possui solenidade alguma; consistia numa fórmula tão banal; para Desbonnets, era um formulário "vale para-tudo". Assim, não houve aprovação solene, aprovação sim, da Regra bulada. Além disso, é o único caso de confirmação de uma Ordem religiosa por uma bula "Solet annuere", que se encontra nos bulários de Inocêncio III e de Honório III. A forma como a Regula bullata foi inserida não é destituída de significado. Desbonnets levanta a hipótese de que os Frades menores não possuíam uma Ordem regularmente expressa em forma de preceito e não tinham propriedades, por isso não teriam recebido o privilégio Religiosam vitam ${ }^{143}$.

Diferentemente, os dominicanos foram aprovados por Honório III no dia 31 de dezembro de 1216, com a bula Religiosam vitam eligentibus, assinada por dezenove cardeais e o papa; não foram aprovados como Ordem Mendicante (a categoria não existia ainda), mas como Ordem dos cônegos, adotando a Regra agostiniana.

Como veremos mais adiante, a Regra de 1223 representou um certo engessamento de um movimento em plena expansão. As frases relacionadas à pobreza revelam-nos a cristalização de um projeto de vida que visava a atender aos pobres no meio dos pobres e seguir Cristo pobre. Com a normativa definitiva, os franciscanos passaram a integrar o projeto de Reforma da Igreja

\footnotetext{
${ }^{142}$ Cf. DESBONNETS, T. Op. cit., pp. 106-115.

${ }^{143}$ DESBONNETS, T. Op. cit., p. 112.
} 
iniciado no século XII, inclusive a expansão franciscana foi uma consequência disso. A partir desse momento, a Cúria Romana deu um papel bem definido para o movimento Franciscano.

\subsection{Fora de Assis: expansão e consolidação da institucionalização}

Desde o início, o movimento Franciscano demonstrou uma grande mobilidade geográfica. De dois em dois, os frades percorriam as regiões da Itália central, com itinerários a partir da cidade Úmbria na qual a fraternitas se havia constituído. Aos poucos,avançaram para a Itália setentrional e meridional. Pouco se sabe desta primeira fase de itinerância; o que sabemos vem dos parcos testemunhos das fontes bio-hagiográficas ou de observadores externos também não abundantes, como o relato de Jacques de Vitry de 1216. Também não sabemos ao certo os nomes dos primeiros companheiros de Francisco e o Testamento não fornece nenhuma indicação.

Na Península italiana, os "lugares" em que os frades se multiplicavam eram diversos. Passada a fase de precariedade e a caminho de uma estabilidade, as mais antigas províncias parecem ser a da Toscana, da Marca de Ancona, da Lombardia, da Ligúria e da Púlia. Após a morte de Francisco, acrescentaram-se as províncias de Roma, de Bolonha, de Gênova, da Marca de Treviso, de Penne, de Sant'Ângelo, da Sicília e da Calábria. Devemos lembrar que estas províncias não possuiam limites rígidos ou muito bem definidos; a definição e centralização foram dadas a posterior. Como nos aponta Merlo, a proliferação desse fenômeno de religiones novae estava mudando a paisagem religiosa e urbana de cidades e burgos da Península italiana. "Todas elas uniam-se pela tensão pauperista e pelo desejo de perfeição evangélica, tanto no âmbito tradicional ou renovado, quanto no caritativo-hospitaleiro, monástico-eremítico ou mendicante: dos Crucíferos aos Humilhados e aos cônegos de São Marcos de Mantova, dos Pobres Católicos e dos Pobres Reconciliados aos Frades pregadores, dos Albigenses de Pádua aos grupos eremíticos da Itália central"144. A falta de fontes consiste no principal problema; não há relatos de cronistas que descrevam o tempo, modos

${ }^{144}$ Cf. MERLO, Grado G. Op. cit., pp. 60 e 61. 
e termos globais deste fenômeno que modificou a geografia religiosa de muitas partes da Itália.

Com relação aos franciscanos, o movimento de expansão fora da península italiana iniciou-se no Capítulo geral de Pentecostes de 1217 em Santa Maria da Porciúncula, no qual foram estabelecidos os grupos de frades para as primeiras tentativas de transpor os Alpes, para chegar à Península ibérica, à França, à Alemanha, Terra Santa e, até, à Hungria, na maior parte das vezes os resultados foram desastrosos. De um certo modo, desastrosos porque os frades nem sempre conheciam as línguas do lugar e eram confundidos constantemente com heréticos ou não eram aceitos pelos eclesiásticos locais. Mesmo assim, temos o início da primeira expansão fora da Itália. No Capítulo das Esteiras ${ }^{145}$ de 1217 introduziram-se elementos de maior organização, como a divisão em províncias sob a direção de um ministro (minister provincialis), marcando o início da prática sistemática de enviar frades em missão. Como bem assinala Grado Merlo, não sabemos em que modelo institucional os Menores se inspiraram para a criação das províncias e das custódias. Porém, sabemos que a primeira expansão não foi feita tão ao acaso. Mas a experiência destas missões estão presentes nos diversos capítulos da Regra não bulada e bulada, como resultado da dificuldade da pregação itinerante da primeira expansão. Além disso, cada vez mais aumentava a necessidade de construção de uma norma jurídica mais concisa, clara e organizativa.

Segundo John Moorman, a Itália foi dividida em seis províncias Toscana, Lombardia, a Marca de Ancona, Terra do Trabalho, Púlia e Calábria. A França foi dividida em duas províncias, uma para o norte e outra para o sul. Uma província foi criada para a Alemanha, apesar de nenhum frade ter andado lá , uma província para a Espanha e outra para a Terra Santa ${ }^{146}$.

$\mathrm{Na}$ Península Ibérica ${ }^{147}$, os primeiros frades sob a orientação de Frei Zacarias foram tratados como indesejáveis, até o momento em que a família

\footnotetext{
${ }^{145} \mathrm{O}$ título Esteiras advém da generosidade da população local que ofereceram aos frades abrigos (esteiras) e uma mesa farta para o encontro segundo as hagiografias de Boaventura.

${ }^{146}$ MOORMAN, John. "L'espanzione Francescana dal 1216 al 1226". In: Francesco d'Assisi e francescanesimo dal 1216 al 1226. Espoleto: Atti della Società Internazionale di studi francescani, 1977, p. 272.

${ }^{147}$ Cf. MAGALHÃ̃ES, Ana Paula Tavares. "Aspectos relacionados ao estabelecimento da Ordem Franciscana em Portugal: séculos XIII e XIV." In: MEGIANI, Ana Paula Torres \&
} 
real thes concedeu sua proteção. Eram frequentemente confundidos com os albigenses. Sabemos através da Crônica de Jordão de Jano de 1262 que graças aos esforços da rainha Urraca e do rei Afonso II, os frades estabeleceram-se em Lisboa e em Guimarães em 1217. Logo depois, com o apoio da infanta Sancha, cunhada de Urraca, estabeleceram-se nos arredores de Coimbra, na localidade de Olivais. Os frades tiveram apoio dos reis em Portugal e rapidamente espalharam-se pela Península Ibérica. No entanto, somente com a segunda leva em 1219, sob a orientação do florentino frei João Parente, junto com cem frades, conseguiram estabelecer os primeiros "lugares" fixos franciscanos em Toledo, Saragoça, Teruel e Coimbra. São, entretanto, informações muito escassas e fragmentárias, pouquissímo material sobre o assunto, o que dificulta a nossa análise.

Bem diferente é a situação relativa às missões dos frades além dos Alpes e do Canal da Mancha. Para a Alemanha, a Chronica de Jordão de Jano possui bem mais informações, porém lembramos que é um texto de caráter menos analítico, configura-se numa narração não historicamente predisposta e ordenada, terminada nos anos sessenta do século XIII. O historiador italiano Luigi Pellegrini nos informa que a primeira missão na Alemanha não só foi um fracasso. Como praticamente os frades desconheciam a língua alemã, foram confundidos com heréticos; seu número era de aproximadamente sessenta frades $^{148}$. Mas 1220 foi 0 ano das grandes restruturações organizativas em relação ao recrutamento. Segundo Merlo ${ }^{149}$, na segunda missão de 1221 o empreendimento da Alemanha se revelou mais fácil devido principalmente às recomendações papais. Desta vez, os frades enviados eram três de origem alemã (Cesário de Espira, Barnabé, Conrado) e um húngaro (Abraão), os outros oito provinham da Itália central, exceto Frei José de Treviso. Frei Cesário de Espira era perito nas Sagradas Escrituras; Frei João de Pian del Carpine era pregador em língua latina e língua lombarda; Frei Barnabé pregava bastante em língua lombarda e em língua alemã; Frei Tomás de Celano foi o redator da primeira legenda de São Francisco. Em geral, a metade era

SAMPAIO, Jorge Pereira de. (Org.). Inês de Castro: a época e a memória. 1 ed. São Paulo: Alameda, 2008, v. 1, pp. 59-78.

${ }^{148}$ PELLEGRINI, Luigi. "Storia e Geografia del 'reclutamento' francescano". In: I compagni di Francesco e la prima generazione minoritica. Atti del XIX Convegno internazionale, Assisi, 1719 ottobre 1991. Espoleto: Centro Italiano di studi sull'alto medioevo, 1992, p. 20.

${ }^{149}$ MERLO, Grado G. Op. cit., pp. 61-63. 
constituída de sacerdotes de boa cultura e qualidade, lista sempre incompleta quanto ao número exato de frades. Assim, os temidos maus-tratos não se repetiram. Frei João de Pian del Carpine e Frei Barnabé conseguiram estabelecer hospitia em Wurzburg, Mogúncia, Worms, Espira, Estrasburgo e Colônia; Frei Jordão de Jano, com os Freis Abraão e Constantino, dirigiram-se para Salsburgo onde não conseguiram se estabelecer de imediato. No início de 1223, Frei Tomás de Celano foi nomeado custódio da área que compreendia as cidades de Mogúncia, Worms, Colônia e Espira. Em menos de dois anos, organizaram uma notável expansão nas terras da Alemanha, com sedes destinadas a se tornarem estáveis e com uma primeira organização territorial, graças ao apoio de bispos locais e de membros do clero maior.

Já na Inglaterra, Tomás de Eccleston, que foi ministro provincial da Inglaterra, escreveu entre 1258 e 1259 a obra De Adventu Fratrum Minorum in Anglia, organizada em quinze collationes ou "conversas espirituais" na qual relata a experiência inglesa, descrevendo desde a chegada até os primeiros trinta anos da presença menorita na ilha. A missão franciscana na Inglaterra iniciou-se no dia 10 de setembro de 1224 com cinco leigos e quatro clérigos, entre os quais o ministro provincial, Frei Agnello de Pisa, que fora "custódio de Paris", designado por Frei Francisco, sendo três clérigos de origem inglesa, dois frades leigos, quatro eram de origem italiana e um francês, de consistência numérica bem inferior àquela da missão alemã. Instalam-se em Canterbury, indo depois para Londres e Oxford, sempre com apoio dos Frades pregadores, apoio já combinado em Paris. Sabemos que antes da morte de Francisco, os Menores se expandiram para Cambridge, Northampton, Norwich, Worcester, além de Salisbury e York. Os Menores também se dirigiram para a Irlanda, instalando-se em nove das trinta e quatro cidades. De pouca importância foi a difusão na Escócia e quase inexistente em Gales ${ }^{150}$.

Para Manselli ${ }^{151}$, quando os frades chegaram à França meridional e à França setentrional com o seu hábito incomum, foram imediatamente confundidos com hereges. Fizeram-Ihes perguntas e confundiram-nos com os albigenses. Segundo John Moorman ${ }^{152}$, a missão na França meridional em

\footnotetext{
${ }^{150}$ Cf. MERLO, G. G. Em nome de Francisco...., pp. 64 e 65.

${ }^{151}$ Cf. MANSELLI, R. Op. cit., p. 190.

${ }^{152}$ MOORMAN, John. Op. cit., p. 273.
} 
1217 foi confiada a frei João Bonelli de Firenze, que teve pouco sucesso, talvez pela dificuldade da língua. Dois anos depois, partiram para uma nova expedição orientanda por um frade francês, Christopher de Cahors, fundando em Provença muitas casas em locais estratégicos nas cidades de Arles, Nîmes, Montpellier e Tolosa. A expedição setentrional foi orientada por frei Pacífico, chegou nos subúrbios de Paris em 1218-1219, e o sucessor de Pacífico, Gregorio de Nápolis, pôde inaugurar conventos em muitas cidades e rapidamente os frades entraram em contato com as universidades.

Segundo Merlo ${ }^{153}$, os frades foram bem acolhidos em Paris nos anos de 1219-1220, devido ao apoio pontífice dado pela Carta Cum dilecti filii de Honório III, provavelmente de 11 de junho de 1219, e também pela Carta Pro dilectis filiis de 29 de maio de 1220 do mesmo papa, endereçada aos bispos e nobres da França, recomendando a Ordem dos Frades menores com o objetivo de tranquilizar o bispo local Pedro de Nemours.

Em relação à Hungria, Manselli não faz uma análise aprofundada, apenas informa que os frades divididos em grupos viajavam pela planície, foram recebidos com hostilidades, suas vestes teriam sido roubadas e foram constrangidos a voltar para a Itália, informações essas retiradas da Crônica de Jordão de Jano. A Legenda dos Três Companheiros também nos informa de maneira vaga e sintética a experiência fora da Itália. Mas são relatos singelos acerca da expansão geográfica, principalmente no tocante à Hungria.

Antes de iniciarmos a experiência franciscana na Terra Santa, devemos lembrar que a palavra sarracenos ${ }^{154}$ designava na Idade Média 0 nome pelo qual se chamavam os árabes nômades e depois, particularmente, os muçulmanos árabes da época de Francisco. Além disso, pela primeira vez na história da Igreja, apresentava-se um "método" de apostolado de aproximação dos muçulmanos numa mentalidade unicamente evangélica e pela primeira vez aparecia na Regra de uma ordem religiosa um capítulo consagrado à evangelização dos muçulmanos, consta na Regra não bulada, no capítulo dezesseis intitulado "Dos que quiserem ir para entre os sarracenos e outros infiéis", uma série de recomendações práticas de como lidar com os

\footnotetext{
${ }^{153}$ MERLO, Grado G. Op. cit., p. 59.

154 BASETTI-SANI, Giulio. "Sarracenos". In: CAROLI, Ernesto (Org.). Dicionário Franciscano. Petrópolis: Vozes, 1999, pp. 691-700.
} 
não-cristãos. Por exemplo, como abordar um muçulmano: primeiro, realiza-se o testemunho do exemplo, evitando rixas e disputas teológicas; em segundo lugar, os frades devem ser reconhecidos pelos muçulmanos como "hóspedes enviados por Deus", por isso não devem provocar contendas e discussões; os frades deveriam ser sempre mansos e pacíficos.

Fratres vero, qui vadunt, duobus modis inter eos possunt spiritualiter
conversari. Unus modus est, quod non faciant lites neque
contentiones, sed sint subditi omni humanae creaturae propter Deum
(1Pet 2,13) et confiteantur se esse christianos. Alius modus est, quod,
cum viderint placere Domino, annuntient verbum Dei, ut credant
Deum omnipotentem, Patrem et Filium et Spiritum Sanctum (cfr. Mat
28,19 ), creatorem omnnium, redemptorem et salvatorem Filium, et ut
baptizentur et efficiantur christiani, quia quis renatus non fuerit ex
aqua et Spiritu Sancto, non potest intrare in regnum Dei (cfr. loa
$3,5) .{ }^{155}$

Tanto na Regra não bulada quanto na bulada está presente a questão da conversão do muçulmano, elaboração advinda provavelmente das experiências de 1219 em que Frei Francisco se transfere para o além-mar, onde já se encontrava Frei Elias, ministro da Província da Síria, para levar pessoalmente o seu testemunho cristão ao mundo islâmico. Um ano depois, em 1220, sucedeu o episódio do martírio dos cinco frades em Marrocos, martírio mais simbólico que concreto. Em resumo, os historiadores não são unânimes quanto à data da visita de Francisco ao sultão do Egito. Provavelmente, Francisco dirigiu-se à Melek-el-Kamel afim de estabelecer relações de paz. Para Amin Maalouf ${ }^{156}$, não existem fontes do lado muçulmano para provar o encontro entre Francisco e el-Kamel.

Segundo os postulados de Merlo, foi fundamental o apoio de pessoas da cúpula das igrejas locais e do papado, uma das condições, também institucionais, por meio das quais os Menores conseguiram ser aceitos nas cidades. Assim, a fraternidade das origens, de fisionomia penitencial, estava cada vez mais distante, mas ativa para uma Ordem que devia responder às exigências do papado, que se via assumindo compromissos político-

\footnotetext{
${ }^{155}$ Regula non bullata 16, 5-7. MENESTÓ, Fontes franciscani..., pp. 199.

${ }^{156} \mathrm{O}$ autor mistura literatura e história para descrever as cruzadas do ponto de "vista árabe", para nós interessa, o trecho em que o autor coloca em dúvidas se realmente Francisco de Assis encontrou-se com o sultão Melek-el-Kamel, já que não há fontes no lado muçulmano a respeito de São Francisco. MAALOUF, Amin. As cruzadas vistas pelos árabes. São Paulo: brasiliense, 2001, p. 250.
} 
eclesiásticos e pastorais tão longínquos a partir do simples testemunho cristão de pouco mais de dez anos antes; uma Ordem numerosa com uma difusão muito ampla na cristandade latina e com relações sociais sempre mais fortes e extensas $^{157}$. Portanto, a redação da Regra não bulada e bulada foi resultado das experiências pastorais missionárias realizadas antes de 1223.

Além de tudo, como nos recorda John Moorman, é muito difícil calcular o número exato de frades naquela época. Podemos pensar em cinco mil frades participantes do Capítulo das Esteiras em 1219. Mas isso é certamente um exagero, como são outros cálculos no Medievo. Temos cifras precisas somente nos conventos singulares de época mais tardia, mas pouca informação sobre a Ordem inteira. Pouco tempo depois, o número total dos frades era provavelmente de cerca de mil e quinhentos, mas é impossível saber quantos fossem em 1226. O fato é que a Ordem crescia rapidamente devido à notoriedade que ia ganhando na sociedade com as pregações numa época na qual o clero paroquial sabia bem pouco da arte da oratória. ${ }^{158}$.

Neste momento, os frades estavam adquirindo igrejas conforme nos atestam duas bulas do papa Honório III (1216-1227); são elas, a bula Devotionis vestrae precibus, de 29 de março de 1222 e a Quia populares, do início de dezembro de 1224. A primeira foi dirigida a Frei Francisco e aos Frades menores e a segunda apenas aos frades da Ordem dos Menores e foram escritas após um explícito "pedido" dos destinatários que haviam solicitado licença de celebrar os ofícios divinos nas suas igrejas, também em tempo proibido, e a missa em altar portátil, conforme o trecho abaixo.

Onorio vescovo, servo dei servi di Dio, ai diletti figli, i frati dell'Ordine
dei minori, [invia] salute e apostolica benedizione.
Poiché, fuggendo lo strepito delle piazze come cosa che impedisce il
vostro proposito di vita, voi cercate volentieri luoghi isolati per potervi
dedicare più liberamente in santa quiete all'orazione; noi facciamo
grande assegnamento sulla impetrazione molto necessaria delle
vostre preghiere, poiché tanto più efficace deve essere la vostra
intercessione presso Dio, quanto più, vivendo perfettamente, siete
degni di grazia maggiore da parte di lui.
Perciò, considerando che non si può negarvi una cosa per la quale
non si deroga ai diritti di nessuno, mentre la vera religione chiede che
dobbiamo concedervi anche ciò che è favore speciale, poiché non
domandate una comodità temporale ma spirituale per la vostra
devozione, dal momento che avete professato e anche abbracciato la

${ }^{157}$ MERLO, Grado G. Op. cit., pp. 64 e 66.

${ }^{158}$ MOORMAN, John. Op. cit., p. 277. 
povertà; noi, favorevoli alle vostre preghiere, con l'autorità del presente scritto vi concediamo il privilegio che nei vostri luoghi e oratori possiate celebrare il sacrificio della messa e gli altri divini uffici con altare mobile, salvo sempre ogni diritto parrocchiale riservato alle chiese parrocchiali. ${ }^{159}$.

Com a Quia populares, os Frades menores obtiveram o privilégio de poder celebrar a eucaristia e os ofícios divinos nos tais oratórios, podiam celebrar nas igrejas até mesmo com a porta fechada. Nesta ocasião, o movimento Franciscano vinha adquirindo uma maior estabilidade institucional e consolidação da própria autonomia. A concessão já havia sido dada a outras Ordens religiosas; mais tarde, outros privilégios foram entrando no movimento, como a concessão de terem sepulturas próprias ${ }^{160}$ nos seus "lugares". Contudo, o mais importante foi que com essas medidas o crescimento da pastoral da Ordem cresceu significativamente, como observamos com a Carta Vineae Domini custodes de 7 de outubro de 1225 de Honório III, endereçada aos Pregadores e Menores, missionários "no reino do Maramolim (Marrocos)" que, entre outras coisas, tinham a autoridade de absolver os excomungados e de pronunciar sentenças contra os hereges segundo o trecho abaixo selecionado.

\begin{abstract}
Tenendo, dunque, presente che voi avete rinunciato a voi stessi e bramate dare la vostra anima per conquistare al Signore le anime degli altri, poiché è risaputo che nessun sacrificio è più gradito a Dio che il bene delle anime, voi l'autorità della Sede apostolica manda nel regno del Miramolino, perché, annunciando il Vangelo del Signore Gesù Cristo, per quanto egli concederà, convertiate gli infedeli, rialziate quanti sono caduti rinnegando la fede, siate il sostegno dei deboli, la consolazione dei paurosi e il coraggio dei forti.

Perché poi possiate esercitare il vostro ministero con maggior sicurezza, vi concediamo che possiate, però solo in quella regione, predicare, battezzare $i$ saraceni che venissero alla nostra religione, riconciliare gli apostati, ingiungere le penitenze e assolvere quanti, scomunicati, non possono comodamente raggiungere la Sede apostolica. Vi sai ancora lecito pronunciare sentenze di scomunica contro coloro che, in quella regione, passassero all'eresia.

Proibiamo anche a ogni cristiano che vi scacci con la violenza da quella terra.

A voi poi comandiamo; in virtù di santa obbedienza, che non osiate abusare di questa facoltà, ma, come genuini operai di Gesù Cristo, vi comportiate in un modo così irreprensibile che possiate meritare il denaro della ricompensa dal divino Padre di famiglia, e che noi possiamo con fiducia assegnarvi compiti ancora maggiori. ${ }^{161}$
\end{abstract}

\footnotetext{
159 Os grifos são nossos para ressaltar os termos empregados. Bolla "Quia populares" di Onorio III. In: CAROLI, Ernesto (org.) Fonti Francescane, nuova edizione...., p. 1713.

${ }^{160}$ Com a bula Ita vobis de Gregório IX promulgada no dia 26 de julho de 1227.

161 Os grifos são nossos para ressaltar os termos empregados. Bolla Vineae Domini custodes di Onorio III. In: CAROLI, Ernesto (org.) Fonti Francescane, nuova edizione...., pp. 1714-1715.
} 
Através das cartas acima mencionadas, conseguimos ter uma melhor dimensão da perplexidade do Testamento, no qual Frei Francisco informou que os frades tivessem "ecclesias, habitacula paupercula et omnia que pro ipsis construuntur", contanto que fossem conforme a "santa pobreza" prometida na Regra e ele impôs, ao mesmo tempo, que os frades não pedissem mais privilégios através de cartas à Cúria Romana em favor de uma igreja ou de outro lugar, "aliquam litteram in curia Romana [...] neque pro ecclesia neque pro alio loco"; mas os pedidos e recebimentos de privilégios aumentavam junto com o crescimento da Ordem.

Estas informações devem ser interpretadas como indícios das mudanças profundas que se operavam. Essas preocupações aparecem no Testamento de Frei Francisco de 1226, conforme mencionamos, revelando uma imediata concretude.

Tais privilégios contribuiram em muito para o movimento de expansão e solidificação da Ordem Franciscana nas regiões da Europa do Ocidente medieval latino e, sobretudo, estreitaram as relações com a Igreja. Assim, o movimento Franciscano encaminhava-se para a consolidação institucional com esse crescimento numérico advindo da pastoral e expansão rápida, com o ingresso de homens cultos e fundações de conventos fixos em cidades estratégicas da cristandande latina ocidental, somada a estima com que os frades eram tratados pelas autoridades civis ou religiosas, a pregação eficiente e uma quantidade de elementos que não entravam na percepção dos frades "fundadores" da fraternitas. Esta expansão direcionava a Ordem para uma transformação de um projeto de vida maleável e aberto para uma prática da Regra precisa e fechada, talvez fosse algo inconsciente e inevitável ao movimento.

\subsection{Testamentum: a fase final da primeira geração menorita}

Nas últimas décadas cresceu entre os historiadores o interesse pelo Testamento; talvez seja o escrito que mais "conserve algumas características da linguagem de Francisco", não somente pelo fato de ser uma biografia escrita pelo próprio biografado (talvez ele obteve ajuda para tal empreendimento); no 
entanto, representa uma autorevelação de uma consciência que compreendia alguns apontamentos sobre a própria experiência evangélica de si e de seus primeiros companheiros numa visão que pretendia ser autobiográfica. Para o historiador italiano Giovanni Miccoli ${ }^{162}$, o Testamento é o único documento que aparece como relato, apresentação e sumário da experiência religiosa global de Francisco, da "conversão" à iminência da morte. Só por este fato já bastaria para se partir dele para melhor entendermos o movimento Franciscano.

O Testamentum beati Francisci de 1226 inicia a narração em primeira pessoa do itinerário de Frei Francisco, desde a conversão, para depois passar decididamente ao plural, o que acontece após a "revelação do Senhor", onde Francisco e seus companheiros foram chamados para viver "segundo a forma do Santo Evangelho".

Se pensarmos em termos de conteúdo, o Testamento não destoa totalmente da Regra de 1223. Concordamos com Frei Carlo Paolazzi em que a Regra e o Testamento constituem mais uma unidade, um complemento, não se opondo em termos de ideias e discurso; ao contrário, formam um conjunto que chamamos de "herança jurídica" da primeira geração menorita, que conhecia apenas os escritos de Frei Francisco. Sabatier via o Testamento como algo contrário à institucionalização da Ordem e um protesto contra a Regra de 1223. Para ele, a Regra era um contrato mediado pela Igreja Romana e o Testamento seria o documento mais próximo das origens do franciscanismo primitivo; essa análise ainda prossegue numa parte da historiografia recente, assim como em grupos autonômos franciscanos da atualidade que preferem seguir o Testamento e não a Regra (vista como limitadora porque impõe normas derivadas do direito canônico) como conduta de vida.

Em termos linguísticos, o Testamentum, Regula non bullata e Regula bullata possuem significativas diferenças, o que "provaria" ser esse corpus documental resultado de um trabalho coletivo na sua redação, como nos aponta o linguísta Nino Scivoletto, ao invés de pensarmos numa incompetência literária de Francisco conforme as hagiografias colocam, sendo por isso alguns frades encarregados de colocar os escritos e seus pensamentos de forma organizada, justificando a ajuda de Cesário de Espira na redação da Regra não

\footnotetext{
${ }^{162}$ MICCOLI, Giovanni. Francisco de Assis. Realidade e memória de uma experiência cristã. Petrópolis: Vozes, 2004, p. 52.
} 
bulada, a intervenção do cardeal Hugolino e bulas da Cúria Romana. Não é por acaso que as cartas mais longas e outros escritos diziam que oficiais podiam ajudar na confecção, sobretudo os especialistas em latim, ou afirmar que o Testamento representava uma tradução operada ali por irmãos secretários aos quais o santo ditava em vulgar porque era incapaz de exprimir os seus pensamentos em latim. ${ }^{163}$.

Nino Scivoletto alerta-nos que ao invés de preocupar-nos com uma leitura direta e aprofundada dos escritos comparando termo por termo, poderiamos pensar que a transmissão oral deveria ser o meio predileto de Francisco para se expressar, por isso não é possível fazer uma "leitura" dos seus escritos sem levar em consideração o coletivo. $O$ stilus $^{164}$ dos documentos obedece às normas de um mesmo stilus, advindas da própria experiência psicológica e da exaltação da beleza da verdade evangélica, segundo as definições dos teóricos do século XIII.

${ }^{163} \mathrm{O}$ autor italiano fez neste artigo um estudo linguístico sobre os termos semânticos empregados nos escritos de Francisco, ele deu uma atenção especial as Regras e Testamento porque ainda discutia-se no período em que ele escreveu a autoria dos textos legislativos, se era ou não exclusividade de Francisco. SCIVOLETTO, Nino. "Problemi di língua e di stile degli scritti latini di san Francesco". In: Francesco d'Assisi e francescanesimo dal 1216 al 1226. Assisi, 15-17 ottobre 1976. Atti della Società Internazionale di Studi francescani. Assis: Centro interuniversitario di studi francescani , 1977, volume IV, pp. 109-110.

${ }^{164} \mathrm{Tal}$ estilo era bem conhecido da cultura medieval que Nino Scivoletto sintetiza: "Le sue caratteristiche possono essere così sintetizzate: parallelismo e antitesi come strutture portanti del discorso, ricerca a scopo ornamentale di tutti gli effetti fonici raggiungibili con l'allitterazione e l'anafora, con le figure etimologiche e la paronomasia, con l'omoteleuto e l'omoioptoto, con l'accumulo di commata e di cola, e, infine, con la rima in tutte le sue combinazioni, incrociata, interna e finale. Sono proprio questi i tratti esornativi degli opuscula che saltano subito agli occhi di un lettore e si riscontrano in tutti e non solo in quelli di natura laudativa, come dimostrata, per fare un solo esempio, il seguente brano della Regula non bullata:

Omnes diligamus ex toto corde,

ex tota anima,

ex tota mente,

ex tota virtute et fortitudine,

ex toto intellectu et omnibus viribus,

toto nisu, toto affectu,

totis visceribus, totis desideriis et voluntatibus

Dominum Deum, qui totum corpus,

totam animam,

totam vitam dedit et dat omnibus nobis,

qui nos creavit [et] redemit et sola sua

misericordia salvabit,

qui nobis miserabilibus et miseris, putridis et fetidis, ingratis et malis

omnia bona fecit el facit.

Regula non bullata, c. 23, 8. SCIVOLETTO, Nino. Op. cit., pp. 121-122. 
Enfim, mesmo com as diferenças linguísticas do latim empregado, partimos da premissa de uma harmonia entre o conteúdo da Regra e do Testamento, que pode ser comprovada em várias passagens, e é isso o que nos interessa aqui. Neste caso, comparar o conteúdo das Regras com o do Testamento se faz fundamental. Como nos aponta Carlo Paolazzi com um exemplo: "Uma confirmação importante parece vir ainda de uma passagem do Testamento, onde Franciso escreve: "O Senhor me revelou que disséssemos esta saudação: O Senhor te dê a Paz", trecho que coincide com Lucas 10, 5, citado na Regra não bulada no Capítulo XIV, entre a formulação parece apontar a saudação "Paz a esta casa" em situações mais gerais, utilizando ao escopo um breve trecho da antiga benção bíblica ("Convertat Dominus vultum suum ad te, et det tibi pacem", Nm 6, 26) já usada por frei Leão (cfr. FF 262). Também no Testamento, a "revelação" de viver segundo a forma do Santo Evangelho e a "revelação" da saudação, apesar de deixadas fora do texto se referem evidentemente a um único acontecimento. "165.

Alguns aspectos já discutidos serão aqui retomados para realizarmos a comparação entre o Testamento e as Regras. No início do Testamento o videre leprosos pode ser atributo de um fato histórico ocorrido ou uma alusão a Mateus 10,8, leprosos mundate (recordamos que o trecho inspira-se em toda conversão de Francisco), em outros excertos, feci misericordiam cum illis é iunctura bíblica e, seja o que for, podemos pensar também na expressão exivi de seculo como exemplificação de São Paulo (1Cor. 5, 10), de hoc mundo exiisse (mundus no apostólo indicava a vida terrena com os seus vícios: avareza, avidez, idolatria etc). Outros trechos do Testamento como sed ubicumque non fuerint recepti, fugiant in aliam terram ad faciendam penitentiam cum benedictione Dei e simplex et infirmus são um evidente reflexo de Mateus 10,14 e 23, et quicumque non receperit vos... fugite in aliam, e no segundo trecho o termo infirmus, no sentido em que foi transladado, também revela passagem de uma mesma ressonância bíblica. Assim, como bem demonstra Nino Scivoletto, as Regulae e o Testamentum revelam-se, antes de tudo, um conjunto de trechos bíblicos selecionados.

\footnotetext{
${ }^{165}$ Cf. PAOLAZZI, Carlo. Lettura degli "Scritti" di Francesco d'Assisi. Milano: Edizioni Biblioteca
} Francescana, 2002, p. 291. 
Tais trechos trazem revelação e vida "segundo o Santo Evangelho", o fundamento da vida apostólica dos Menores, um retorno ao ideal de vida evangélica reformista iniciado com os cistercienses e sintetizado no movimento Franciscano nos pontos correspondentes aos sete principais aspectos da Regra que já mencionamos anteriormente.

\begin{abstract}
Et illi qui veniebant ad recipiendam vitam, omnia quae habere poterant (Tob I, 3), dabant pauperibus; et erant contenti tunica una, intus et foris repeciata, cum cingulo et braccis. Et nolebamus plus habere. Officium dicebamus clerici secundum alios clericos, laici dicebant: Pater noster (Mat 6,9-13); et satis libenter manebamus in ecclesiis. Et eramus idiotae et subditi omnibus. Et ego manibus meis laborabam (cfr. Act 20,34), et volo laborare; et omnes alli fratres firmiter volo, quod laborent de laboritio, quod pertinet ad honestatem. Qui nesciunt, discant, non propter cupiditatem recipiendi pretium laboris, sed propter exemplum et ad repellendam otiositatem. Et quando non daretur nobis pretium laboris, recurramus ad mensam Domini, petendo eleemosynam ostiatim. Salutationem mihi Dominus revelavit, ut diceremus: Dominus det tibi pacem (cfr. 2 The 3,16$).{ }^{166}$
\end{abstract}

Os trechos do Testamento acima mencionado, 16-23, correspondem exatamente aos seguintes trechos da Regra bulada ${ }^{167}$, localizados no capítulo 1, versículos 2-3, capítulo 2, versículos 6-7, capítulo 3, versículos 2 e 4,

166 Cf. Testamentum, 16-23, MENESTÒ, Enrico \& BRUFANI, Stefano (org.). Fontes Franciscani. Assis: Edizioni Porziuncola, 1995, pp. 228-229.

${ }^{167}$ Os seguintes trechos mencionados da Regra bulada: "Regula et vita Minorum Fratrum haec est, scilicet Domini nostri Jesu Christi sanctum Evangelium observare vivendo in obedientia, sine proprio et in castitate. Frater Franciscus promittit obedientiam et reverentiam domino papae Honorio ac successoribus eius canonice intrantibus et Ecclesiae Romanae. [...] dicant illis verbum sancti Evangelii, quod vadant et vendant omnia sua et ea studeant pauperibus erogare. Quod si facere non potuerint, sufficit eis bona voluntas. [...] Clerici faciant divinum officium secundum ordinem sanctae Romanae Ecclesiae excepto psalterio... Laici vero dicant viginti quatuor Pater noster pro matutino... [...] Praecipio firmiter fratribus universis, ut nullo modo denarios vel pecuniam recipiant per se vel per interpositam personam. [...] Fratres illi, quibus gratiam dedit Dominus laborandi, laborent fideliter et devote, ita quod, excluso otio animae inimico, sanctae orationis et devotionis spiritum non extinguant, cui debent cetera temporalia deservire. De mercede vero laboris pro se et suis fratribus corporis necessaria recipiant praeter denarios vel pecuniam et hoc humiliter", e da Regra não bulada: "Regula et vita istorum fratrum haec est, scilicet vivere in obedientia, in castitate et sine proprio, et Domini nostri Jesu Christi doctrinam et vestigia sequi, qui dicit: $\mathrm{Si}$ vis perfectus esse, vade et vende omnia quae habes, et da pauperibus et habebis thesaurum in caelo; et veni, sequere me. [...] Propter hoc omnes fratres sive clerici sive laici faciant divinum officium, laudes et orationes, secundum quod debent facere. Clerici faciant officium et dicant pro vivis et pro mortuis secundum consuetudinem clericorum. [...] Laici dicant Credo in Deum et viginti... [...] sed sint minores e subditi omnibus, qui in eadem domo sunt. Et fratres, qui sciunt laborare, laborent et eandem artem exerceant... Et iterum: Otiositas inimica est animae. [...] Fratres tamen in manifesta necessitate leprosorum possunt pro eis quaerere eleemosynam. [...] Omnes fratres studeant sequi humilitatem et paupertatem Domini nostri Jesu Cristi... Et eleemosyna est hereditas et iustitia, quae debetur pauperibus, quam nobis acquisivit Dominus noster Jesus Cristus. [...] Et in quamcumque domum intraverint, dicant primum: Pax huic domui. Et in eadem domo manentes edant et bibant quae apud illos sunt". MENESTÒ, Enrico \& BRUFANI, Stefano (org.). Fontes Franciscani..., pp. 185-200. 
capítulo 4, versículo 2, capítulo 5, versículos 2-4 e da Regra não bulada localizados no capítulo 1, versículos 1-2, capítulo 3, versículos 3-4 e 10, capítulo 7, versículos 2-3 e 11, capítulo 8, versículo 10, capítulo 9, versículos 18, capítulo 14, versículos 2-3. Nem tudo presente no Testamento está de acordo com as Regulae; um exemplo de trecho divergente é em referência aos hábitos; no Testamento, no versículo 16, há menção somente a uma túnica: "e estavam contentes com uma só túnica ... e mais não queríamos ter" e na Regra não bulada (capítulo 2, versículo 13) e bulada (capítulo 2, versículo 15) mencionam-se duas túnicas, uma com capuz e outra sem capuz para aqueles que entrassem para o noviciado.

O Testamentum representaria uma etapa final do processo de institucionalização do movimento dos Menores. Para Paolazzi, este texto de final de vida deveria ser classificado como "um compêndio exemplar" de uma experiência de conversão evangélica vivida por Francisco e seus companheiros. Não há nada de protesto contra a Regra de 1223. O próprio documento fornece os objetivos e o gênero retórico que aqui já discutimos. $A$ definição de gênero dada pelo próprio documento: isto é "uma recordação, uma admoestação, uma exortação (recordatio, ammonitio, exhortatio)" que "Frei Francisco pequenino (frater Franciscus parvulus)" dirige a seus frades, com a finalidade de conscientizá-los do significado evangélico e universal da opção religiosa que fizeram no momento em que entraram (e entrarão) na Ordem menorita, a fim de observarem mais catolicamente a Regra, e este texto não é outra Regra. Conforme Miccoli:

\begin{abstract}
Sugere-o o caráter interno do texto que, com toda a evidência, é a manifestação e a reafirmação suprema das próprias opções de vida e das próprias vontades para a fraternidade - os verbos "volo", "nolo" ocorrem onze vezes, duas vezes a expressão "praecipio firmiter per obedientiam", numerosíssimas são as construções optativas ou de comando, e, aliás, o próprio Francisco diz tê-lo composto a fim de que a regra seja observada "melius catholice" - e o confirmam alguns elementos e algumas circunstâncias externas ${ }^{168}$.
\end{abstract}

Como bem observa Grado Merlo, o Testamento aparece como uma integração explicativa e até mesmo normativa da Regra. Tem o sentido de esclarecer mais profundamente as formulações legais contidas nesta última, ou

${ }^{168}$ MICCOLI, G. Op. cit., p. 53. 
seja, as intenções originárias e originais do seu fundador ${ }^{169}$. Assim, a recordação de Frei Francisco parte de um convite à penitência. O início da caminhada começa sob o signo da graça divina, num tempo não precisado, mas que poderia ser posto uns vinte anos antes de ditar o Testamento, talvez em 1205, a partir do contato pessoal e misericordioso com indivíduos atingidos pela lepra, o que está de acordo com a normativa. O texto fornece a informação de que o contato com os leprosos seria a premissa de um indeterminado mas breve período de reflexão e da decisão definitiva de "sair do século". Em seguida, seguem logo algumas intensas declarações sobre a fé do neoconvertido Francisco nas igrejas e nos sacerdotes e sobre sua necessidade de concretude, de tangibilidade e de visibilidade do Divino.

Para Merlo ${ }^{170}$, Francisco, através da simbologia da Cruz, tirou a simples oração de fé "em todas as igrejas" de Jesus Cristo, que estão "em todo o mundo" e de bênção da "santa cruz", por meio da qual Cristo redimiu o mundo. Assim, no Testamento, da "fé nas igrejas" passou para a "fé nos sacerdotes", inclusive os mais miseráveis, que "vivem segundo a forma da santa Igreja Romana". O respeito aos sacerdotes que celebram o mistério eucarístico e podem administrar o sacramento aos outros, recebe a máxima veneração. Francisco optou pela total submissão aos sacerdotes, aspecto que coincide com a normativa de 1223. Até esta parte, o Testamento constitui memória.

\footnotetext{
Et Dominus dedit mihi talem fidem in ecclesiis, ut ita simpliciter orarem et dicerem: Adoramus te, Domine Jesu Christe, et ad omnes ecclesias tuas, quae sunt in toto mundo, et benedicimus tibi, quia per sanctam crucem tuam redemisti mundum. Postea Dominus dedit mihi et dat tantam fidem in sacerdoti-bus, qui vivunt secundum formam sanctae ecclesiae Romanae propter ordinem ipsorum, quod si facerent mihi persecutionem, volo recurrere ad ipsos. ${ }^{171}$
}

Depois disso, a partir da sétima frase o Testamentum passa a ser exortação e admoestação, a fim de que os Frades não se deixem tomar pela tentação de se sentirem os melhores em relação aos sacerdotes, com base numa pretensa superioridade moral e intelectual. "Et si haberem tantam

\footnotetext{
${ }^{169}$ MERLO, G. G. Op. cit., p. 20.

170 MERLO, Grado G. Op. cit., p. 21.

171 Testamentum, 4-6. MENESTÒ, Enrico \& BRUFANI, Stefano (org.). Fontes Franciscani..., p. 227.
} 
sapientiam, quantam Salomon habuit, et invenirem pauperculos sacerdotes huius saeculi, in parochiis, quibus morantur, nolo praedicare ultra voluntatem ipsorum." ${ }^{172}$. A seguir, os objetivos do Testamento começam a se manifestar nos conteúdos polêmicos. Ademais, conforme Merlo ${ }^{173}$, a recordação da tradição de ortodoxia vinda do passado e conservada no presente pela Igreja romana, que era considerada a única autenticamente ligada a Cristo naquele momento, foi um critério reproposto de comportamento para os Frades, como fundamento católico para uma opção evangélica radical, distinta de outras experiências pauperista-evangélicas marcadas por uma relação bastante crítica em relação a hierarquias e homens da Igreja. Como é o exemplo de Valdo de Lião e seus seguidores que, no fim dos anos setenta do século XII, haviam mantido uma estreita conexão com a opção de pobreza evangélica e o anúncio da Palavra, mas com uma acentuação "doutrinal" e um direto esforço antiherético que, ao contrário, não serão encontrados em Frei Francisco e seus primeiros companheiros, cuja pregação insistia na dimensão penitencial e moral. Com isso, podemos traçar um paralelo diferenciado de opção pauperista-evangélica entre a vida de Francisco de Assis e de Pedro Valdo, sobretudo quanto ao desfecho.

Assim, a primeira parte do Testamento é encerrada. A segunda parte inicia-se com elementos autobiográficos bastante escassos do ponto de vista dos fatos e dos acontecimentos, enquanto são bastante fortes as afirmações de princípio e muito clara a profissão de fé de Frei Francisco, bem elaboradas para quem estava bastante doente no momento da sua redação.

Resumidamente, Francisco, com a conversão, praticou a penitência durante um período de permanência no meio aos leprosos: teve posteriormente um breve momento de reflexão, daí a decisão de sair do mundo, consequentemente veio a descoberta da concretude da encarnação de Jesus Cristo/Deus através das coisas que no mundo recordam e deixam transparecer a encarnação divina. Conforme os postulados de Merlo ${ }^{174}$, não temos referência cronológica, apenas sequencial dos fatos, fornecida numa estrutura

\footnotetext{
${ }^{172}$ Testamentum, 7. IDEM, Ibidem, pp. 227-228.

173 MERLO, Grado G. Op. cit., pp. 22, 24 e 25.

${ }^{174}$ MERLO, G. G. Op. cit., p. 22.
} 
antropológica, teológica, sacramental, eclesiológica e devocional com uma forte ressonância bíblica sobretudo pelo evangelho de Mateus.

No Testamento, Frei Francisco recorda ainda que o fato de ter assumido o estado de penitente lhe faz superar a situação precedente, "quando estava em pecados (cum essem in peccatis)", expressão que não diz muito. Depois disso, Francisco penitente e solitário não previa reunir discípulos, não procurou nenhum seguidor; foram dados por Deus. A solução encontrada pela fraternitas foi espelhada na fórmula "vivere secundum formam sancti evangelii", um motivo inspirador que exprimia melhor o "desígnio divino", sem complicadas elaborações intelectuais e jurídicas. Dessa maneira, o propósito de vida ou a fórmula era simples e linear. De uma maneira consequencial e plana, Francisco recebeu irmãos e escreveu com brevidade e simplicidade a proto-regra, que recebeu autenticação da autoridade pontifícia.

Como já mencionamos, os fatos são lineares e indolores, como se os que tivessem lido ou ouvido o Testamento devessem pôr em memória que Frei Francisco, com obstinada firmeza, propunha a si mesmo, como fundamento e critério de autenticidade da experiência menorita passada, presente e futura, na específica perspectiva que o "viver segundo a forma do santo Evangelho", partia de Deus para chegar a Francisco que, pessoalmente, procurou e recebeu autenticação de Inocêncio III. O texto prossegue com a recordação dos primeiros companheiros com opção pela pobreza, oração e frequência às igrejas. O total depojamento comporta a renúncia aos bens materiais, a interdição de posse e o compromisso de dedicar-se ao trabalho manual.

Um texto que os frades deveriam ler junto com a Regra que o papa Honório III (1216-1227) havia confirmado com a carta Solet annuere, no dia 29 de novembro de 1223. Mas, o Testamento não é outra Regra como o próprio texto nos informa, nem uma retratação. A diferença da Regra para um Testamento é uma questão de gênero retórico. A primeira se configura numa norma religiosa amplamente usada pela Igreja para melhor definir as Ordens religiosas ou o clero regular de acordo com o direito canônico vigente, que tem a sua própria hierarquia e títulos específicos, distinguindo-se do clero secular. Já o gênero Testamento significa uma manifestação da última vontade de Frei Francisco, que se dirige a todos os frades, aos que fazem parte do movimento e aos que virão; isso não significa que deva ser classificado junto com o texto 
da "Última vontade escrita por São Francisco a Santa Clara", conforme defende Martino Conti ${ }^{175}$. Para Grado Merlo, as Regras e o Testamento tomam parte no "código genético do franciscanismo", o difícil patrimônio ou herança do movimento Franciscano, não apenas para a primeira geração, mas para toda a posterioridade. Apesar de serem gêneros retóricos distintos, o conteúdo é complementar e instigante. O Testamentum reafirma os principais temas da Regula bullata, como viver a pobreza, sem propriedade, com o espírito de peregrinos e forasteiros, como a passagem abaixo.

\begin{abstract}
Caveant sibi fratres, ut ecclesias, habitacula paupercula et omnia, quae pro ipsis construuntur, penitus non recipiant, nisi essent, sicut decet sanctam paupertatem, quam in regula promisimus, semper ibi hospitantes sicut advenae et peregrini (cf 1Petr 2, 11). Praecipio firmiter per obedientiam fratribus universis, quod ubicumque sunt, non audeant petere aliquam litteram in curia Romana, per se neque per interpositam personam, neque pro ecclesia neque pro alio loco neque sub specie praedicationis neque pro persecutione suorum corporum; Sed ubicumque non fuerint recepti, fugiant in aliam terram ad faciendam poenitentiam cum benedictione Dei. ${ }^{176}$
\end{abstract}

Outro exemplo de unidade entre os documentos estaria no trecho sobre a obediência aos frades, a hierarquia franciscana centralizada na figura do ministro geral e no cardeal protetor e corretor da Ordem dos Frades menores.

\begin{abstract}
Et firmiter volo obedire ministro generali huius fraternitatis et alio guardiano, quem sibi placuerit mihi dare. Et ita volo esse captus in manibus suis, ut non possim ire vel facere ultra obedientiam et voluntatem suam, quia dominus meus est. Et quamvis sim simplex et infirmus, tamen semper volo habere clericum, qui mihi faciat officium, sicut in regula continetur. ${ }^{177}$
\end{abstract}

Não menos importante era o respeito aos ministros provinciais, custódios e toda as demais hierarquias da Igreja, assim como a leitura do ofício divino. Os trechos trinta ao trinta e três do Testamento coincidem com a obediência à hierarquia da Regra bulada no capítulo dez, versículo três e capítulo doze dos versículos três e quatro.

\footnotetext{
${ }^{175}$ CONTI, Martino. Op. cit., p. 277.

${ }^{176}$ Testamentum, 24-26. MENESTÒ, Enrico \& BRUFANI, Stefano (org.). Fontes Franciscani..., p. 229-230.

177 Testamentum, 27-29. IDEM, Ibidem, p. 230.
} 
Et omnes alii fratres teneantur ita obedire guardianis suis et facere officium secundum regulam. Et qui inventi essent, quod non facerent officium secundum regulam, et vellent alio modo variare, aut non essent catholici, omnes fratres, ubicumque sunt, per obedientiam teneantur, quod ubicumque invenerint aliquem ipsorum, proximiori custodi illius loci, ubi ipsum invenerint, debeant repraesentare. Et custos firmiter teneatur per obedientiam ipsum fortiter custodire, sicuti hominem in vinculis die noctuque, ita quod non possit eripi de manibus suis, donec propria sua persona ipsum repraesent in manibus sui ministri. Et minister firmiter teneatur per obedientiam mittendi ipsum per tales fratres, quod die noctuque custodiant ipsum sicuti ho-minem in vinculis, donec repraesentent ipsum coram domino Ostiensi, qui est dominus, protector et corrector totius fraternitatis. ${ }^{178}$.

Para Merlo ${ }^{179}$ é muito importante a referência aos que ocupam posição de direção no seio da Ordem, porque eles poderiam intervir para modificar os conteúdos do Testamento e trazer novas interpretações complementares à Regra. Entretanto, o aspecto mais importante a ressaltar seria a imposição a todos os frades, clérigos e leigos, para que não fizessem glosas à Regra e nem ao Testamento, dizendo que assim deveriam ser lidos; no entanto, veremos que as "autoridades" da Igreja e da Ordem trouxeram significativas glosas aos textos. Enfim, a explicação implícita é que a Regra e o Testamento foram redigidos por vontade divina "de forma simples e pura" e igualmente "de forma simples e sem glosa", deveriam ser lidos e entendidos por todos os frades, o que não acontecia. A partir deste trecho abaixo aparecem alguns dos objetivos polêmicos de Frei Francisco, os frades dirigentes e os frades "intelectuais" da Ordem, os detentores de poder e saber que teriam permitido introduzir (ou já haviam introduzido) modificações significativas na Regra e, eventualmente, no Testamento e, portanto, na "espinha dorsal" do franciscanismo. Seriam perceptíveis as preocupações de Frei Francisco referentes às evoluções que tendiam a produzir as metamorfoses da Ordem, como a ascensão dos frades para os altos escalões da Igreja e da sociedade.

Et in omnibus capitulis quae faciunt, quando legunt regulam, legant et ista verba. Et omnibus fratribus meis clericis et laicis praecipio firmiter per obedientiam, ut non mittant glossas in regula neque in istis verbis dicendo: ita volunt intelligi. Sed sicut dedit mihi Dominus simpliciter et pure dicere et scri-bere regulam et ista verba, ita simpliter et sine glossa intelligatis et cum sancta operatione observetis usque in finem. Et quicumque haec observaverit, in caelo repleatur benedictione altissimi Patris et in terra repleatur benedictione dilecti Filii sui cum sanctissimo Spiritu Paraclito et omnibus virtutibus caelorum et

\footnotetext{
${ }^{178}$ Testamentum, 30-33. IDEM, Ibidem, pp. 230-231.

${ }^{179}$ MERLO, Grado G. Op. cit., p. 43.
} 
omnibus sanctis. Et ego frater Franciscus parvulus vester servus quantumcumque possum, confirmo vobis intus et foris istam sanctissimam benedictionem. ${ }^{180}$.

A recomendação da leitura conjunta da Regra e do Testamento somada à advertência de não adicionar glosas e nem comentários nos dois documentos marcaram o início de uma polêmica duradoura na Ordem. As principais indagações sobre a Regra e o Testamento gravitavam em torno da seguinte questão, a saber: seriam ambos os documentos um complemento por isso deveriam ser lidos com o mesmo estatuto jurídico, já que em termos de conteúdo e autoria pertenciam a um mesmo autor? Outra questão bastante polêmica era como definir em que consistia a pobreza da normativa franciscana, visto que o texto legislativo de 1223 provocava inúmeras interpretações, justamente por não haver uma definição fechada da paupertas Christiana franciscani.

Enfim, finalizamos com as considerações tecidas por Merlo ${ }^{181}$. Frei Francisco faleceu na noite de 3 para 4 de outubro de 1226, na igreja de Santa Maria da Porciúncula (na planície aos pés do Monte Subásio), liberando as potencialidades inseridas na união entre o franciscanismo e a Igreja romana, assim como liberou a direção dos frades de uma presença forte e exemplar que se tornara pesada, numa fase em que a Ordem era sacudida por não pequenos conflitos. Porém, enquanto Francisco estava vivo, existia um critério de autenticidade encarnado na sua própria pessoa, mas depois, a discussão em torno da pobreza passou a deslizar não mais na experiência religiosa de vida de Francisco de Assis, mas na codificação desta experiência que se encontrava na Regra e na problemática questão de como esta deveria ser interpretada.

\subsection{O problema da "herança jurídica" e da canonização de Frei Francisco}

A "herança jurídica" de Frei Francisco localiza-se nos documentos legislativos da Ordem dos Menores; a principal herança é atestada pela premissa da pobreza franciscana como condição para se atingir a perfeição

\footnotetext{
${ }^{180}$ Testamentum, 37-41. MENESTÒ, Enrico \& BRUFANI, Stefano (org.). Fontes Franciscani..., p. 231-132.

${ }^{181}$ MERLO, Grado G. Op. cit., p. 46.
} 
evangélica na economia da salvação. As "condições" de vida evangélica às quais os frades menores deveriam ater-se, antes de tudo não podiam esquivarse das normas canônicas; segundo a norma jurídica vigente que havia distinguido, desde sempre, o ideal monástico: "scilicet vivere in obedientia, in castitate et sine proprio", aparecem em ambas as Regulae, mas na Regula non bullata - a obediência foi posta em primeiro lugar, a castidade em segundo e a pobreza por último; já na Regula bullata aparece: "vivendo in obedientia, sine proprio et in castitate" - em primeiro a obediência, em segundo a pobreza e em terceiro a castidade.

Antes de mais nada, o mais importante girava em torno da obediência à Igreja. O texto de 1221 não é institucional ainda, por isso a concepção "secundum formam sancti evangelii" passou em 1223 para "secundum formam sanctae romanae ecclesiae". Essas pequenas sutilezas jurídicas não interferiram na concepção da pobreza franciscana e nem sufocou a novidade de inspiração pauperística ${ }^{182}$, como nos aponta Stanislao. A precisa aposição jurídica "nullus recipiatur contra formam et institutionem ecclesiae" (tem um desfecho mais adiante em "nullus fratrum praedicet contra formam et institutionem ecclesiae") era seguramente introduzida para garantir que os pregadores franciscanos estivessem longíquos de toda heresia, e voltados a uma vita religiosa conforme a Regra de 1223.

$\mathrm{Na}$ Regra de 1223, as seguintes passagens apontam-nos para uma delimitação da paupertas franciscana de forma mais institucional, do capítulo um "Regula et vita Minorum Fratrum haec est, scilicet Domini nostri Jesu Christi sanctum Evangelium observare vivendo in obedientia, sine proprio et in castitate" e do capítulo dois "... dicant illis verbum sancti Evangelii, quod vadant et vendant omnia sua et ea studeant pauperibus erogare (cfr. Mat 19,21). A interdição de posse somada aos elementos de recusa ao dinheiro e esmolar constituem a base do movimento Franciscano. Como já foi exemplificado, o viver sem nada de próprio tem origem bíblica, uma resignificação da primeira geração menorita para os que ingressavam na Ordem. Assim, deveriam vender todos os seus bens e distribuí-los em benefício dos pobres. Desta forma,

182 CAMPAGNOLA, Stanislao da. La povertà nelle "regulae" di Francesco d'Assisi. In: La povertà del secolo XII e Francesco d'Assisi. Atti del II Convegno Internazionale. Assis: 1975, pp.234-235. 
deveriam realizar pessoalmente o sentido da pobreza evangélica na via ativa, por meio do cuidado aos pobres e do amor ao necessitado; esses dois elementos eram determinantes para a entrada nesta Ordem religiosa segundo a norma. De maneira geral, significava que os frades não poderiam ter bens nem individuais, nem comunitários .

Conforme a Regra, o viver pobre não se limitava ao âmbito interior do homem; deveria manifestar-se no sentido interior e exterior, com consequências no campo material, por isso as recomendações em relação aos hábitos pobres do capítulo dois: "Et fratres omnes vestimentis vilibus induantur et possint ea repeciare de saccis et aliis peciis cum benedictione Der" e à proibição de andar a cavalo no capítulo três: "Et non debeant equitare, nisi manifesta necessitate vel infirmitate cogantur". O sentido mais profundo da pobreza franciscana era fixado numa "vida sem nada de próprio", não receber dinheiro ou moedas estava claramente expresso na normativa "Praecipio firmiter fratribus universis, ut nullo modo denarios vel pecuniam recipiant per se vel per interpositam personam", e no capítulo cinco: "De mercede vero laboris pro se et suis fratribus corporis necessaria recipiant praeter denarios vel pecuniam et hoc humiliter, sicut decet servos Dei et paupertatis sanctissimae sectatores". É claro que o dinheiro era um objeto sempre rejeitado como inconciliável com a pobreza voluntária desta Ordem mendicante, porque significava apropriar-se de alguma coisa. Para resolver este problema, criou-se a figura dos "amigos espirituais", que cuidariam das doações em dinheiro feitas aos frades e da necessidade dos frades, sempre tendo a pobreza como fundamento. $O$ viver com o mínimo ou suficiente não era assim tão preciso na regra. Nem sempre era possível determinar esse grau de pobreza normativa na vida prática cotidiana dos conventos, o que teria gerado muitas tensões entre os frades da "comunidade" (conventuais) e os frades "rigoristas" (no século XIV conhecidos por "espirituais" segundo a Igreja).

No capítulo seis, a ausência de bens foi fixada pelas seguintes frases "Fratres nihil sibi approprient nec domum nec locum nec aliquam rem. Et tanquam peregrini et advenae (cfr. 1Pet 2,11) in hoc saeculo in paupertate et humilitate Domino famulantes vadant pro eleemosyna confidenter, nec oportet eos verecundari, quia Dominus pro nobis se fecit (cfr. 2Cor 8,9) pauperem in 
hoc mundo" e no capítulo doze "paupertatem et humilitatem et sanctum evangelium Domini nostri Jesu Christi, quod firmiter promisimus, observemus.".

Esta releitura da pobreza exposta pela Regra de 1223 foi formulada de acordo com o Corpus Juris Canonici da Cúria Romana. Enfim, o espírito primitivo do franciscanismo foi adaptado às normativas da ortodoxia da Igreja, não mudando o espírito dos primeiros tempos ou da fraternitas, mas o problema da "herança jurídica" de Frei Francisco começava no debate em torno da pobreza codificada na normativa, pois os franciscanos jamais chegariam a um consenso sobre como deveriam ser interpretados os pontos principais da Regra Franciscana. A divergência interna iniciou-se quando Francisco ainda era vivo. Assim, todas as modificações pareceram refluir devido às tensões internas, interferências externas e sobretudo criou-se uma inevitável divisão interna em relação à interpretação da norma.

Assim, os elementos básicos da pobreza franciscana presentes na Regulae e no Testamentum configuram-se por meio das recomendações de vestuário vil, da privação de calçados, da ausência de domicílio fixo, da subsistência pelo trabalho manual cotidiano, da rejeição ao dinheiro e do recurso humilhante à esmola, todos descritos no corpus documental. Podemos sintetizá-los na negação de toda forma de apropriação. A Regra bulada de 1223 é derivada da Regra de 1221, por isso tem em comum o ponto fundamental de viver sem propriedade nem individual e nem em comum (interdição de posse), premissa que norteia toda a documentação legislativa da Ordem, diferenciando-se das demais regras de Ordens religiosas.

Ademais, ao analisar algumas informações advindas das bulas papais nas quais Francisco pos mortem deixou em vida os "sinais" de sua santidade, e partindo do processo de canonização de Francisco percebemos que ele recebeu rapidamente o reconhecimento pontifício de sua santidade, completando a mudança de uma metamorfose de grande importância na Ordem. Conforme Merlo ${ }^{183}$ : "desta maneira, a santidade de Francisco de Assis foi celebrada e completada em nível institucional. De maneira rápida, a Santa Sé elevou o testemunho cristão e humano de Frei Francisco ao plano da singularidade e da unicidade próprias de um santo, sem aquele valor de

${ }^{183}$ MERLO, Grado G. Op. cit., p. 46. 
exemplaridade possível de ser seguida que havia permitido o grande e diversificado recrutamento das origens".

O institucionalizar São Francisco significou organizar algo com o auxílio de um aparato normativo a fim de conseguir um resultado duradouro e permanente. Assim, as finalidades de Frei Francisco deviam fazer as contas com um aparato normativo que, para ser eficaz, necessariamente devia prever instrumentos de afirmação humana e coercitiva, ou seja, os instrumentos que Francisco havia recusado como estranhos à mais autêntica sequela Christi, ao mais genuíno "viver segundo a forma do santo Evangelho". Segundo Merlo, não podemos resumir o franciscanismo ao arquétipo São Francisco (modelo psicocultural abstrato, sem nenhuma concretude própria da condição humana e que age em níveis subterrâneos, labirínticos e obscuros, onde a consciência se perde); devemos pensar no movimento Franciscano e na multiplicidade de componentes e estratificações do franciscanismo;. assim seria o melhor caminho proceder da seguinte forma:

Na verdade, o arquétipo São Francisco não age apenas entre seus
'filhos'; exerce uma fascinante atração difusa, como santo e como
Francisco de Assis. Aqui não é preciso deter-se em razões e
mecanismos, institucionais e culturais (antropologicamente culturais),
através dos quais o arquétipo se transforma em veículo de ideologia
ou de ideologias e, portanto, em agente de responsabilização
individual e coletiva. ${ }^{184}$.

A canonização de Frei Francisco aconteceu no dia 18 de março de 1227, um dia após a morte de Honório III, e pouco mais de cinco meses após a morte de Francisco. Logo após, o cardeal protetor Hugolino foi eleito papa, com o nome de Gregório IX (1227-1241). A canonização rápida deu indícios de que já havia junto à Igreja Romana a vontade de inscrever Frei Francisco no catálogo dos santos com rapidez. Era um projeto de grande fôlego, com o envolvimento da cúpula da Ordem e, em particular, de Frei Elias, o mesmo "Vigário do bemaventurado Francisco" que enviou "cartas de consolo" a toda a Ordem para anunciar aos frades, entre outras coisas, os "estigmas e outros milagres que, depois de sua morte, o Altíssimo dignou-se operar por meio do bemaventurado Francisco". Sendo assim, a crucificação e a estigmatização significaram o anúncio de um evento extraordinário (um "signum" que, antes de

${ }^{184}$ MERLO, G. G. Op. cit., p. 17. 
Francisco, somente Jesus Cristo havia mostrado), Francisco aparecia então como um "alter Christus", mas também um prenúncio de santidade, ao qual não parecem estranhas as sugestões ou adesões dos ambientes da Cúria Romana e, com grande probabilidade, do próprio cardeal Hugolino, o protetor da Ordem $^{185}$.

Gregório IX (1227-1241, com a carta Recolentes qualiter de 29 de abril de 1228, concedia indulgência de quarenta dias a quem fizesse ofertas para a construção da igreja em que deveria ser conservado o corpo do "bemaventurado Francisco". Posteriormente, entre maio e junho de 1228, desenvolveram-se em Assis os processos de canonização de Francisco, que foi decretada no consistório ocorrido em Perugia no início de julho: a cerimônia pública ocorreria na cidade de Assis no dia 16 do mesmo mês.

\begin{abstract}
Meditando come la santa piantagione dell'Ordine dei frati minori incominciò e meravigliosamente crebbe, sotto il beato Francesco di santa memoria, spandendo ovunque, per grazia di Gesù Cristo, i fiori profumo di una vita santa, così che il decoro della santa Religione sembra venire dall'Ordine sopraddetto; ci è sembrato cosa degna e conveniente che per riverenza verso lo stesso padre venga edificata una chiesa particolare nella quale si debba riporre il suo corpo.

Poiché dunque per una tale opera si rende opportuno il concorso dei fedeli, e reteniamo che sai utile per la vostra salvezza se vi mostrerete in questo figli devoti e porgerete una mano d'aiuto, preghiamo tutti voi, vi ammoniamo e vi esortiamo nel Signore, e ve lo comandiamo per la remissione dei vostri peccati, che per tale opera eroghiate pie elemosine dalle ricchezze a voi concesse da Dio e sussidi dettati dalla gratitudine della carità, e così voi, per questa e per le altre buone opere che compirete, dietro ispirazione divina, possiate raggiungere $\mathrm{i}$ gaudi della felicità eterna.

Noi infatti, facendo assegnamento sulla misericordia di Dio omnipotente e sull'autorità dei santi apostoli Pietro e Paolo, a tutti coloro che parteciperanno con l'aiuto a quest'opera concediamo misericordiosamente il condono di quaranta giorni sulla penitenza a loro imposta. ${ }^{186}$.
\end{abstract}

A carta Recolentes já anunciava um prenúncio de um novo Santo canonizado e definitivamente instituiu-se o projeto que a Cúria Romana tinha para o movimento Franciscano. Prova disso, podemos aferir, o reconhecimento canônico da santidade de Frei Francisco que se tornou público com a carta Sicut phialae aureae, cujos dois primeiros exemplares são datados de 9 de julho de 1228. Consiste num texto breve com o objetivo de comunicar as

\footnotetext{
${ }^{185}$ MERLO, Grado G. Op. cit., pp. 46 e 47.

${ }^{186}$ Bolla "Recolentes" di Gregorio IX. In: CAROLI, Ernesto (org.) Fonti Francescane, nuova edizione...., pp. 1715-1716.
} 
decisões pontifícias sobre a santidade do bem-aventurado Francisco, indicado como "fundador e reitor da Ordem dos Frades Menores", que atingiu a salvação eterna e cuja "vida e fama claríssima" são capazes de chamar à conversão os pecadores, com efeitos bastante positivos no "robustecimento da fé da Igreja" e na "confusão da herética maldade". Fixou-se o dia 4 de outubro como o da festa de São Francisco.

II est salutaire que nous évoquions la conversion, la vie et les mérites du bienheureux François, le fondateur et le chef de l'Ordre des Frères mineurs. (François) qui parvint aux biens éternels après avoir méprisé les biens transitoires, selon les conseils du Sauveur et selon sa promesse de parvenir ainsi heureusement à la récompense céleste. (François) dont la vie et l'illustre renommée a dissipé les ténèbres des pécheurs qui marchaient dans le pays de l'ombre de la mort, en les invitant à passer des ténèbres des vices à une vie de pénitence. II a encouragé à adhérer à la foi de l'Eglise, en combattant la dérive de l'hérésie. II vit encore aujourd'hui et veille sur une grande multitude d'hommes et de femmes. Ceux-là connaissent clairement et avec certitude ce que par vous-mêmes et par beaucoup d'autres personnes dignes de foi vous savez de ses vertus reconnues et des miracles que Dieu a opérés par les mérites de ce saint homme, lui qui vécut spirituellement au milieu d'êtres charnels et qui eut parmi les hommes une conduite angélique. Lui qui, son corps étant détruit, a mérité d'être au ciel avec le Christ, afin qu'il ne manque pas de recevoir I'honneur et la gloire qui lui sont dus, et afin que Dieu ne permette pas qu'il soit privé de la dévotion des hommes.

C'est pourquoi, ayant pris conseil de nos Frères et de tous les prélats qui assistent présentement le Siège apostolique, nous procédons à l'inscription au catalogue des saints de ce François. Donc, puisqu'il a brillé comme une lumière en ce monde, et puisque par la grâce de Dieu, il n'est déjà plus sous le boisseau mais a mérité d'être placé sur le candélabre, nous vous prions, vous tous, nous vous avertissons et vous exhortons instamment par les présentes lettres apostoliques de commander et d'exciter la dévotion des fidèles pour cet homme, afin qu'à votre tour vous annonciez et célébriez solennellement sa fête chaque année, le 4 octobre : Ce jour fixé pour être célébré afin que Dieu, aux prières de Francois, nous accorde sa grâce ici-bas et la gloire dans le monde futur. ${ }^{1 / 3}$

Diferentemente da carta pontifícia anterior, o texto da bula Mira circa nos do mesmo ano (não é possível precisar o dia), mostra-se um texto muito mais longo, articulado e meditado. Assim, a construção bíblica e teológica da santidade do bem-aventurado Francisco tem uma declarada referência aos conhecimentos pessoais e à familiaridade que Gregório IX, ex-cardeal protetor da Ordem franciscana, tinha tido com Francisco; ele conhecia a sua verdadeira intentio, segundo o próprio papa. A Mira circa nos possui muitas citações do

\footnotetext{
187 A datação da bula Sicut phialae aureae é de 9 de julho de 1228. Disponível em:
} <http://www.wikitau.org/index.php5/Sicut_phialae_aureae> Acesso em: 30 Maio 2010. 
Antigo e Novo Testamento, sobretudo para atribuir a Deus o mérito de haver suscitado a santidade do "seu servo bem-aventurado Francisco" na "undécima hora" para que tomasse o cuidado de "sua vinha".

Ecco, il Signore che, mentre distruggeva la terra con l'acqua del diluvio, guidò il giusto mediante una misera arca, non lasciando che la verga dei peccatori gravasse sopra la sorte dei giusti, nell'ora undecima suscitò il suo servo il beato Francesco, uomo veramente secondo il suo cuore, lampada invero disprezzata nei pensieri dei ricchi, ma preparata per il tempo stabilito, mandandolo nella sua vigna perché ne estirpasse le spine e i rovi, dopo aver annientati i filistei che l'assaltavano, illuminando la patria, e la riconciliasse con Dio ammonendola con assidua esortazione.

[...] Questi, finalmente, imitò gli esempi del nostro padre Abramo, uscendo spiritualmente dalla sua terra e dalla sua parentela e dalla casa di suo padre, per recarsi nella terra che il Signore gli aveva mostrato con la sua divina ispirazione. Per correre più speditamente verso il premio della vocazione celeste, e poter più facilmente entrare per la porta stretta, depose il bagaglio delle ricchezze terrene, conformandosi a Colui che, da ricco che era si fece povero per noi, le disperse, le diede ai poveri, perché così la sua giustizia rimanesse in eterno.

[...] Pertanto, poiché già ci erano pienamente noti i tratti più singolari della sua gloriosa vita - per la familiarità ch'ebbe con noi quando eravamo costituiti in ufficio minore - e circa lo splendore molteplice dei miracoli fu fatta piena fede da noi attraverso idonei testimoni, fiduciosi di essere, noi e il gregge a noi affidato, aiutati dalla di lui intercessione e di avere patrono in cielo colui che ci fu amico sulla terra, radunato il concistoro dei nostri fratelli [cardinali] e avuto il loro assenso, abbiamo decretato di iscriverlo per la debita venerazione nel catalogo dei santi.

Stabiliamo che la Chiesa universale celebri devotamente e con solennità la sua nascita al cielo, il giorno 4 ottobre, il giorno cioè in cui, sciolto dal carcere della carne, salì al regno celeste. ${ }^{188}$

A bula acima mencionada traz uma "releitura" do papa Gregório IX sobre a santidade de Francisco, como um "novo modelo" endereçado à Ordem dos Frades menores. Tal "modelo de Francisco" revelou um grande esforço da Igreja em mostrar um santo empenhado na pastoral, a familiaridade do papa com o santo, a santidade atestada pessoalmente por Gregório IX. Ademais, a bula Mira circa nos acentuou a similaridade de Francisco e Cristo com um propósito de propagação rápida da santidade tão bem demonstrada pela apropriação e divulgação de uma "imagem" de Francisco de Assis. Iniciou-se um novo momento de enquadramento do movimento Franciscano.

${ }^{188}$ É difícil precisar uma datação para esta bula, tem muitas divergências em relação ao dia, o mês é julho de 1228. Bolla "Mira circa nos" di Gregorio IX. In: CAROLI, Ernesto (org.) Fonti Francescane, nuova edizione....,pp. 1717-1721. 
Enfim, Gregório IX contou muito com a canonização de Frei Francisco, seja dentro de uma mais ampla visão de história da salvação e da eclesiologia, seja na dependência da confusa situação política do final dos anos vinte do século XIII. Assim, encerrou-se a primeira geração menorita com a institucionalização da canonização de São Francisco e com a difícil "herança jurídica da pobreza franciscana"; além disso, a cidade de Assis conseguiu finalmente ter o seu Santo e independência em relação à Perugia e Espoleto. Depois disso, o papa foi obrigado a deixar Roma por causa das revoltas de cidadãos, coincidindo com o aumento da ameaça de Frederico II e da ruptura entre papado e Império ${ }^{189}$. Para finalizar, a habilidade política do papa Gregório IX com a atuação dos programas de Roma deu um novo direcionamento bastante complexo de importância para a recém criada Ordem mendicante.

${ }^{189}$ Cf. MERLO, G. G. Op. cit., p. 48. 


\section{CAPÍTULO II}

\section{As contendas jurídicas sobre a pobreza franciscana: a relação Regra-Testamento nas constituições papais}

\subsection{O Capítulo de Pentecostes e a bula Quo Elongati ${ }^{190}$, de 1230 , de Gregório IX (1227-1241): o nascimento de um impasse}

Neste capítulo, analisaremos as seis principais constituições papais referentes à pobreza da normativa franciscana; são elas, a saber: a Quo elongat, de 1230, de Gregório IX (1227-1241), a Ordinem vestrum, de 1245, de Inocêncio IV (1243-1254), a Exiit qui seminat, de 1279, de Nicolau III (12771280), a Exivi de paradiso, de 1312, de Clemente V (1305-1314), a $A d$ conditorem canonum, de 1322 e a Cum inter nonnullos, de 1323, de João XXII (1316-1334). Antes de mais nada, iniciaremos a nossa investigação com a formação jurídica dos papas e em seguida avaliaremos as resignificações por eles levantadas sobre a paupertas da norma menorita dentro do momento histórico da produção destas bulas.

Hugolino dei Conti di Segni nasceu no ano de 1170 em Anagni, cidade na qual recebeu a sua primeira formação religiosa. Estudou direito em Bolonha, é considerado um dos papas "juristas" segundo a historiografia, e provavelmente conseguiu o título doutoral na faculdade de Teologia de Paris. Sobrinho de Inocêncio III, foi cardeal-bispo de Ostia e Velletri. Embora a carreira de Hugolino não se tenha iniciado apenas com a subida de Lotario dei Conti di Segni como o papa Inocêncio III (1198-1216). No ano de 1198 Hugolino foi elevado ao cargo de capelão papal e de cardeal diácono de São Eustáquio. E somente em 1206, tornou-se cardeal-bispo de Óstia.

\footnotetext{
190 Trata-se da primeira exposição oficial da Regra de 1223, solicitada por muitas partes para resolver os pontos obscuros da mesma e, sobretudo para clarificar o valor do Testamento e dos comandos que Francisco deixou escrito. Gregório IX responde com segurança aprovando com sufrágio a sua exposição não tanto com o argumento de autoridade pontifícia, mas com 0 argumento de sua familiaridade com Francisco e participador da comissão da Regra como veremos a seguir. Ademais, Gregório IX foi o papa canonizador de São Francisco, fundador da Basílica de Assis e da Inquisição. Para os franciscanos, o papa Gregório IX ficou conhecido como "dominus Ostiensis, qui est dominus, protector et corrector totius fraternitatis" do movimento Franciscano.
} 
Segundo a Enciclopedia dei Papi' ${ }^{191}$, o cardeal Hugolino encontrou-se pela primeira vez com Francisco de Assis no dia 14 de maio de 1217 na cidade de Firenze, exatamente depois de um Capítulo geral dos frades, celebrado na Porciúncula, no qual havia sido decidido o envio de frades pelo mundo cristão e fora da Itália. A partir deste momento, o cardeal de Óstia teria iniciado a sua atuação política dentro da fraternidade menorita. Era um momento delicado para os frades, porque a fraternitas não se tinha adequado às prescrições conciliares com a sua nova forma de vida, somente havia obtido a aprovação oral dada pelo papa Inocêncio III (1198-1216) em 1210.

Mesmo assim, a pedido de Francisco de Assis, o papa Honório III (1216-1227) teria dado um "protetor" aos franciscanos, mas o nome de "dominus de Ostia" teria sido escolhido pelo próprio Frei Francisco segundo as hagiografias de Boaventura. A função do cardeal protetor ${ }^{192}$ era corrigir as situações de perturbação; ele agia como um guia disciplinador "externo", que cuidava das intervenções coercitivas que aos poucos se tornavam necessárias e também exercia influência para a formulação de uma Regra definitiva, mais articulada e orgânica, para ser submetida à aprovação pontifícia. Além disso, o IV Concílio de Latrão de 1215, que já discutimos no primeiro capítulo, também contribuiu em demasia para a necessidade da criação de uma normatização no movimento Franciscano. A fraternitas foi aos poucos forçada a assumir uma forma institucionalizada dentro da normativa canônica vigente. Consequentemente, Inocêncio III esforçou-se para que as Ordens mendicantes entrassem licitamente na Igreja ${ }^{193}$.

Assim, o cardeal Hugolino agia como intermediador dos Frades menores perante o papa. Da mesma forma, atuava e persuadia o movimento Franciscano a mostrar a disponibilidade à institucionalização da fraternidade,

191 CAPITANI, Ovidio. "Gregorio IX". In: ENCICLOPEDIA dei Papi. Roma: Istituto della Enciclopedia italiana, 2000, 2v, p. 363.

${ }_{192} \mathrm{Na}$ Ordem franciscana, a figura de cardeal protetor existe desde 1217, data na qual inicia o processo de institucionalização do movimento Franciscano. As funções do cardeal protetor estão explicitamente descritas na normativa franciscana no final do capítulo XII: "Ad haec per obedientiam iniungo ministris, ut petant a domino papa unum de sanctae Romanae Ecclesiae cardinalibus qui sit gubernator, protector et corrector istius fraternitatis, ut semper subditi et subiecti pedibus eiusdem sanctae Ecclesiae stabiles in fide (cf 1Col 1,23) catholica paupertatem et humilitatem et sanctum evangelium Domini nostri Jesu Christi quod firmiter et promisimus, observemus.". MENESTÒ, Enrico \& BRUFANI, Stefano (org.). Fontes Franciscani..., p. 180.

${ }^{193}$ BOLTON, B. Op. cit., p. 79. 
que deveria se enquadrar nos moldes das demais Ordens religiosas, não perdendo a sua especificidade mendicante. Oficialmente, Hugolino foi nomeado "cardeal protetor" pelo papa Honório III no ano de 1219, período anterior a redação da Regula non bullata, que foi composta em 1221. Antes de tudo, a presença de Hugolino de Óstia na Ordem Franciscana foi importante e ocupou uma posição central, principalmente quando se tratou de chegar à formulação definitiva da Regra ${ }^{194}$.

Antes de mais nada, a Regula bullata ${ }^{195}$ se apresentou como uma confirmação de uma regulamentação que já havia recebido a aprovação verbal de Inocêncio III, como se tratasse de um documento jurídico final de uma caminhada que teve início com a viagem de 1210 da primeira geração menorita à Roma. O Testamento de 1226 ainda nos parece ser a atestação final deste percurso de um processo evolutivo guiado por complexas relações entre frei Francisco, o papa, alguns frades dirigentes, o cardeal Hugolino e a Cúria Romana. Também assinalou o fim da primeira geração menorita conforme já explicitamos no capítulo anterior ${ }^{196}$.

Ao longo dos séculos, o Testamentum beati Francisci foi questionado se deveria ou não ser considerado como parte dos documentos legislativos da Ordem dos Frades Menores. Entretranto, nunca houve um consenso entre os frades medievais em relação ao estatuto jurídico deste documento. Em diferentes momentos, houve o costume de se ler à mesa, juntamente com a Regra, o Testamento. Esta prática não ocorria por acaso; o hábito permanecia principalmente devido aos seguintes trechos do Testamentum que já comentamos anteriormente:

Et non dicant fratres: Haec est alia regula, quia haec est recordatio, admonitio, exhortatio et meum testamentum, quod ego frater Franciscus parvulus facio vobis fratribus meis benedictis propter hoc, ut regulam, quam Domino promisimus, melius catholice observemus. Et generalis minister et omnes alii ministri et custodes per obedientiam teneantur, in istis verbis non addere vel minuere (Deut $4,2 ; 12 ; 32)$. Et semper hoc scriptum habeant secum iuxta regulam. Et

\footnotetext{
194 IDEM. Ibidem, p. 38.

${ }^{195}$ A Regra revela não apenas a autenticidade espiritual de uma Ordem religiosa, mas também a sua norma jurídica. Trataremos aqui os aspectos relacionados diretamente com a pobreza que Gregório IX desenvolveu na Quo eloganti e deixaremos de lado os demais assuntos relacionados à Regra por ele tratada, a obediência, a pregação, a confissão, pecado e correção dos irmãos, eleições de ministros, a admissão de novos irmãos, a proibição da entrada dos frades nos conventos femininos etc.

${ }^{196}$ MERLO, G. G. Op. cit., pp. 39 e 40.
} 
in omnibus capitulis quae faciunt, quando legunt regulam, legant et ista verba. Et omnibus fratribus meis clericis et laicis praecipio firmiter per obedientiam, ut non mittant glossas in regula neque in istis verbis dicendo: Ita volunt intelligi ${ }^{197}$.

Segundo a passagem acima supracitada, os trechos lidos como "polêmicos" pelas gerações posteriores franciscanas, apresentam-se não como uma outra Regra, mas como uma recordatio (recordação), ammonitio (admoestação) e exhortatio (exortação). A sua finalidade e destinatários eram todos os frades e deveria ser observado junto à Regra. Com um tom evocativo insiste que o ministro geral, todos os demais ministros provinciais e custódios deveriam obedecer e nada acrescentar ou diminuir, e, principalmente, dirigiu uma ordenação de comando para que não fossem colocados glosas ou interpretações nos textos da Regra e do Testamento. É bastante complexo destrinchar os significados destas palavras e a verdadeira intentio de Francisco; até o presente momento não houve uma hipótese plausível se alguém o teria ajudado a redigir o Testamento e, menos ainda, sabemos a intenção das frases, se seriam ou não representativas de um grupo. $O$ fato é que a questão da autenticidade desta mensagem de Francisco de Assis se mostrou bastante árdua com a promulgação da Carta Quo Elongati de 28 de setembro de 1230, escrita por Gregório IX em Anagni, após sete anos da Regula Bullata e apresentou-se como uma verdadeira reinterpretação da Regra à comunidade franciscana.

Como bem nos recorda o italiano Andrea Tabarroni, as colocações do papa Gregório IX foram na constituição Quo elongati, a primeira interpretação oficial da Regra franciscana. Tratou-se, como bem enfatizou Herbert Grundmann, de um documento capital na história da Ordem. Ao estabelecer uma lista de pontos obscuros dos trechos aos frades pode-se fazer uma ideia das novas exigências que se desenvolveram no interior da Ordem a partir da regra. As questões controversas são de nove no total. ${ }^{198}$. Esses nove pontos são, a saber: os dois primeiros abordavam conteúdo de natureza geral e diziam respeito à obrigatoriedade do Testamento e da Regra. Duas eram

\footnotetext{
197 O grifo é nosso para ressaltarmos os termos. Testamentum, 34-38. MENESTÓ, Fontes franciscani..., p. 231.

198 TABARRONI, Andrea. "La regola francescana". In: Dalla "sequela Christi" di Francesco d'Assisi all'apologia della povertà. Atti del XVIII Convegno Internazionale. Assisi, 18-20 ottobre 1990. Espoleto: Centro italiano di studi sull'alto medioevo, 1992, pp. 93-94.
} 
relativas à observância da pobreza no tocante ao dinheiro, às esmolas e à relação jurídica dos frades no cotejo dos bens materiais, o que era permitido como propriedade da Ordem no sentido de uso, afirmação do princípio de não ter propriedade comum ou privada, de bens móveis (livros, utensílios...). As outras quatro reportavam ao ordenamento interno da ordem: a discricionalidade dos ministros gerais, provinciais e custódios em relação aos pecados e admissões ou expulsões da Ordem, composição do capítulo geral e a autoridade dos ministros em matéria de confissões, de acolhimento aos postulantes e da concessão do ofício da pregação. Enfim, a última questão tocava no problema da relação entre os frades com os conventos femininos e em particular o das "Pobres Damas". Todos esses nove pontos eram divididos na distinção entre comando e conselho, o que confirmam que se tratou de uma "reescrita" da Regra franciscana ${ }^{199}$.

A relação Regra-Testamento iniciou-se no Capítulo de Pentecostes de 1230, quando os vários capitulares reunidos, entre eles, frei Antônio de Pádua (1195-1231), o ministro geral João Parente, Gerardo de Rossignol, Haimo de Faversham, Leão de Perego, Gerardo de Módena, Pedro de Brescia, decidiram levar uma delegação ao Papa Gregório IX (1227-1241) para que o papa desse uma resposta a respeito de pontos controvertidos da Regra dos Frades menores e também para obter uma solução decisiva a respeito da observância do Testamento junto à Regra bulada. A delegação dos frades que encaminhou tal pedido tinha consciência de que não teria autoridade para intervir, nem diretamente nem mediante a interpretação sobre o texto da Regra. Mas o papa, enquanto a mais alta autoridade e também um dos autores da Regra, tinha autoridade para tal intervenção. Ademais, a mesma delegação não pediu uma nova interpretação do Testamento, somente uma decisão papal da mais alta autoridade em matéria de obediência no período. Assim, Gregório IX tinha que se manifestar e definir uma posição frente aos problemas internos da Ordem.

Segundo Andrea Tabarron, é preciso recordar que havia dois princípios fundamentais na teoria medieval do poder naquele momento, a saber: um era o princípio de soberania no grau mais elevado, que não podia ser limitato por decretos de predecessores (par in parem non habet imperium). $O$ outro era 0

${ }^{199}$ CAPITANI, Ovidio. Op. cit., p. 371. 
princípio que regula o governo de cada universitas, de toda comunidade juridicamente reconhecida. Segundo os estatutos da comunidade, as interpretações deveriam ser aprovadas por todos (quod omnes tangit, ab omnibus approbari debet) ${ }^{200}$. Aplicando esses princípios às questões constitucionais, Gregório IX sancionou definitivamente a natureza jurídica do corpo institucional de universitas; assim a bula Quo elongati foi um ponto de não retorno e a autoridade da Regra não resultou mais precisamente delimitada; assim a validade da Regra franciscana passou a depender da aprovação por parte de todos os frades reunidos no Capítulo geral, sancionada por Gregório IX. Então, um agente externo à Ordem que sancionava os preceitos da Regra deu a autenticidade por meio da autentificação pontíficia que delimitou com precisão do ponto de vista jurídico a autoridade interna da Regra, cuja premissa principal era a pobreza.

Como vimos, o resultado do encontro foi a promulgação da Quo Elongati e a negação do valor jurídico ao Testamentum. A justificativa pontifícia foi que Hugolino dei Conti havia sido o primeiro cardeal protetor da Ordem Franciscana durante dez anos, sendo eleito Papa Gregório IX no ano de 1227, um ano após a morte de Francisco, e conhecia a verdadeira intentio do pobre de Assis devido à familiaridade que teve com o mesmo.

\begin{abstract}
Invero, poco tempo fa, venuti alla nostra presenza i delegati che voi, figli ministri provinciali che eravate al capitolo generale, avete mandato, e con loro personalmente anche tu, figlio ministro generale, ci avete esposto che nella vostra Regola si contengono alcune cose dubbie o oscure e altre difficili a capirsi. Tanto più che il beato confessore di Cristo, Francesco, di santa memoria, non volendo che la sua Regola fosse assoggettata a esposizione attraverso l'interpretazione di nessun frate, prossimo al termine della sua vita comandò - e tale comando si chiama Testamento - che non si facessero glosse (commenti esplicativi) alle parole della stessa Regola, e che non si dicesse, per servirci delle parole di lui, che così o così devono essere intese, aggiungendo che i frati non dovevano chiedere lettere dalla Sede apostolica, e mettendovi anche altre cose che non potrebbero osservasi senza grossa difficoltà. ${ }^{201}$
\end{abstract}

O argumento principal, "familiaridade com Francisco", pleiteado pelo papa, estava inserido num momento em que desaparecia Francisco e a Ordem dos Frades menores conhecia uma crise de identidade perante a progressiva

\footnotetext{
200 TABARRONI, Andrea. Op. cit., pp. 100-101.

201 Bolla "Quo elongati" di Gregorio IX. In: CAROLI, Ernesto (org.) Fonti Francescane, nuova edizione....,p. 1722.
} 
"normatização" e "clericalização" iniciada com Gregório IX, mas continuada com vigor pelos seus sucessores, sobretudo com relação à questão da pobreza.

$\mathrm{Na}$ Carta de 1230, Gregório IX comunicou a seguinte conclusão à Ordem dos Frades menores: ele respondeu por dois vieses, uma resposta pelo ponto de vista histórico e outra pelo ponto de vista jurídico. Do lado histórico, o papa declarou conhecer mais do que ninguém a intenção de Frei Francisco, devido à longa amizade que o próprio Francisco teve com ele quando era cardeal; também porque esteve próximo a ele durante a redação da Regra e sobretudo na comissão dos frades ao apresentá-la à Sé Apostólica para obter a confirmação definitiva ${ }^{202}$.

\begin{abstract}
Per questi motivi, incerti se siate tenuti all'osservanza di detto Testamento, ci avete domandato che rimovessimo con la nostra autorità tale dubbio dalla vostra coscienza e da quella degli altri frati. E poiché, a motivo della lunga familiarità che lo stesso santo ebbe con noi, abbiamo conosciuto più pienamente la sua intenzione, e inoltre fummo a lui vicini durante la stesura della predetta Regola e nel presentarla alla Sede apostolica per ottenerne la conferma, quando eravamo in uma carica inferiore, ci avete domandato con insistenza che anche dichiarassimo i punti dubbi e oscuri della medesima Regola, e dessimo una risposta circa altri punti difficili. ${ }^{203}$
\end{abstract}

Do outro ponto de vista, por se tratar de uma questão jurídica, deveria ser resolvida no nível jurídico-canonístico segundo a exposição papal. Sendo assim, Gregório IX respondeu que, embora Frei Francisco tenha tido uma intenção louvável ao ditar o seu Testamento e os frades fizeram bem em aterse às suas ordens e desejos, no entanto, não eram obrigados à observância por dois motivos. Em primeiro lugar, porque Francisco havia promulgado um documento sem o consenso dos outros frades e principalmente do ministro geral e ministros provinciais. Segundo, Francisco não podia obrigar o seu sucessor (ministro geral) à observância do Testamento, porque não existia poder de um sobre o outro, ou seja, entre os pares que gozam da mesma autoridade.

Ebbene, quantunque noi crediamo che il predetto confessore di Cristo nel dettare comando avesse una lodevole intenzione e che voi pure

202 CONTI, Martino. "Testamento". In: CAROLI, Ernesto. Dicionário franciscano. Petrópolis: CEFEPAL, 1999, p. 744.

${ }^{203}$ O grifo é nosso para enfatizar o uso dos termos empregados. IDEM, Ibidem, p. 1722. 
abbiate a cuore di attenervi fedelmente ai giusti comandi e ai desideri santi di lui, tuttavia noi, preoccupati dei pericoli delle anime e delle difficoltà in cui potreste incorrere a motivo di queste cose, rimovendo il dubbio dai vostri cuori, affermiamo che non siete tenuti all'osservanza di questo comando ${ }^{204}$, per due motivi: egli non poteva, senza il consenso dei frati e principalmente dei ministri, perché riguardava tutti, obbligare; né certamente obbligava in nessuna maniera il suo successore, dal momento che non c'è potere dell'uno sull'altro tra coloro che hanno uguale autorità. 205

\section{Para Esser, com a declaração da constituição papal Quo elongati a} questão Regra-Testamento deveria ter sido encerrada ${ }^{206}$. Contudo, para Martino Conti sempre houve frades que, movidos por diversos motivos ${ }^{207}$, se sentiram obrigados à observância do Testamento ${ }^{208}$. Com isso, deduzimos que a relação Regra-Testamento não foi um assunto totalmente encerrado e menos ainda um consenso entre os frades daquela época. Não obstante, a nossa problemática consiste na interpretação doutrinal do papa, que trouxe uma nova situação jurídica aos Frades menores como veremos ao longo deste segundo capítulo, principalmente em relação à pobreza franciscana normativa.

Primeiramente, a Carta papal inicia-se com a seguinte justificativa, Gregório IX escreveria objetivando melhor esclarecer a relação dos pontos

\footnotetext{
204 Tal decisão será mais tarde reprovada pelos "Espirituais italianos", principalmente por Angelo Clareno da Marca de Ancona.

${ }^{205} \mathrm{O}$ grifo é nosso para realçar as medidas jurídicas empregadas na bula. IDEM, Ibidem, pp. $1722-1723$.

${ }^{206}$ ESSER, K. Op. cit., p. 130.

207 Principalmente, no século XIV com os chamados "Espirituais franciscanos", encabeçados por frei Angelo Clareno e frei Ubertino de Casale que colocaram o Testamento como uma necessidade e complemento da Regra dos Frades menores. Ambos os frades radicalizaram a relação Regra-Testamento, por isso defendiam a igualdade jurídica desses documentos, eles viveram no momento ápice desta discussão. Para Angelo Clareno (c.1245-1337) na sua obra maior Historia septem Tribulationum Ordinis minorum, a observância de forma simples e sem glosa dos dois documentos era uma premissa, visto que ambos foram redigidos por "vontade divina". Com isso, ele acabou construindo o conceito de necessidade da observância do Testamento e o princípio da intocabilidade da Regra que foi diretamente "ditada de Cristo para Francisco". Já Ubertino de Casale (1259-1328) na sua obra de maior relevância Arbor Vitae Crucifixae lesu, reforçando o que já foi mencionado, o perfeito ideal da vida franciscana consistiria em observar o Evangelho, a Regra e o Testamento. Ubertino de Casale escreveu esta obra preocupado com a fidelidade às origens da fraternitas, para ele a Ordem havia decaido em relação à observância da Regra, tanto quanto da intenção e da imitação do primeiro fundador e dos primeiros irmãos. Em 1300, Angelo Clareno também tinha um olhar pessimista em relação aos rumos da Ordem e declarou depois de todos os processos e de todas as lutas, que era melhor sofrer todas as espécies de tormentas e a morte, que se separar da obediência do seu Chefe, do seu vigário e da sua Igreja. Assunto que desenvolvemos melhor no terceiro capítulo desta dissertação.

${ }^{208}$ VAN DIJK, Willibrord-Christian. La représentation de Saint François D'Assise dans les Écrits des Spirituels. In: Franciscains d'Oc. Les Spirituels ca 1280-1324. Toulouse: Cahiers de Fanjeaux, Privat, Editeur, et Centre d'Etudes historiques de Fanjeaux, 1975, pp. 206 e 207.
} 
duvidosos da Regra ${ }^{209}$ e daria uma interpretação jurídica acerca da questão da pobreza e da propriedade dos Frades menores. Em resumo, o papa afirmava que os frades não podiam ter propriedades, nem em comum, nem individualmente seguindo a normativa de 1223, mas era permitido aos frades ter alguns objetos de uso, utensílios, hábito, livros necessários para o ofício divino, instrumentos necessários para seu trabalho e bens móveis de consumo. No entanto, o ministro geral tomava a decisão e dava a permissão de como os frades deveriam usar esses objetos, a fim de que a pobreza da Ordem não fosse deturpada. Enfim, o problema maior estava em como colocar em prática a pobreza codificada na Regra, como medir o uso das coisas no cotidiano prático dos conventos? Difícil decisão que estava centralizada na figura do cardeal protetor e do ministro geral, um embaraço para as províncias mais longínquas já que o poder estava centralizado na Península italiana.

\begin{abstract}
In quarto luogo, poiché nella stessa Regola è detto espressamente: $i$ frati nulla abbiano in proprietà, né casa, né luogo, né qualsiasi altra cosa, ed essi temono che con l'andare del tempo venga contaminata la povertà dell'Ordine, soprattutto perché alcuni hanno già affermato che appartiene a tutto l'Ordine la proprietà in comune dei beni mobili, venne rivolta umile supplica a noi perché riguardo a questo punto ci degniamo di provvedere ai pericoli delle anime e alla purità di tutto l'Ordine.

Diciamo dunque che non devono avere proprietà né in comune né individualmente, ma l'Ordine abbia l'uso degli utensili, dei libri e degli altri beni mobili che è loro lecito avere. I frati poi ne usino secondo quanto sarà stabilito dal ministro generale o dai ministri provinciali, rimanendo intatta la proprietà dei luoghi e delle case nelle mani di coloro ai quali si sanno appartenere. Né devono vendere i beni mobili, né commutarli fuori dell'Ordine o alienarli in qualsiasi modo, a meno che ne abbia concesso l'autorità o il consenso al generale o ai ministri provinciali il cardinale della Chiesa romana che sarà governatore dell'Ordine. ${ }^{210}$
\end{abstract}

Outro ponto tratado por esta constituição papal que diretamente se relacionava à pobreza foi a doação de dinheiro à Ordem dos Menores. A Regra proíbia que os frades recebessem dinheiro; Gregório IX reafirma este preceito. Consequentemente, os frades pediram ao papa que não anulasse a proibição do uso do dinheiro prescrita pela Regra. Para resolver este impasse, Gregório

\footnotetext{
${ }^{209}$ As demais bulas comentadoras da Regra franciscana também utilizaram o mesmo tópos de "esclarecer os pontos duvidosos e obscuros" da normativa dos Menores.

${ }^{210}$ Os grifos são nossos para demonstrar a interpretação formulada a partir do princípio da não propriedade da Regra de 1223. Bolla "Quo elongati" di Gregorio IX. In: CAROLI, Ernesto (org.) Fonti Francescane, nuova edizione...., p. 1724.
} 
IX evoca a figura do "amigo espiritual" conforme a Regra, que guardaria 0 dinheiro dos frades e os mesmos poderiam recorrer a eles mostrando as suas necessidades. Assim, o dinheiro seria propriedade dos benfeitores e os frades receberiam apenas as coisas adquiridas. Mas, ao evocar a figura do "amigo espiritual", Gregório IX definiu o papel dele, que na Regra não estava muito bem claro e reforçou que aos frades estava reservado somente o usus das coisas e não o dominium ou posse.

\begin{abstract}
In terzo luogo, poiché nella stessa Regola si proibisce: che i frati non ricevano da sé o per mezzo d'altri denaro o pecunia in qualsiasi maniera, e questo essi vogliono osservare sempre, si vuole sapere con più sicurezza se possono osare, senza trasgredire la Regola, di presentare a persone timorate di Dio alcuni fedeli attraverso i quali essi soccorrano alle loro necessità [...]

Su questo punto riteniamo di dover rispondere in questo modo: se i frati vogliono comprare una cosa necessaria, oppure pagare una cosa già comprata, possono presentare o l'incaricato di colui dal quale si compra la cosa, o qualche altro, a coloro che vogliono fare loro elemosina (a meno che gli stessi preferiscano fare da sé o per mezzo di propri delegati); questi, così presentato dai frati, non è loro incaricato, sebbene sia presentato da loro, [...] Lo stesso incaricato deve subito provvedere a compiere il pagamento, così che nulla rimanga presso di lui. Se poi fosse presentato per altre necessità imminenti, può depositare l'elemosina a lui consegnata, come lo stesso padrone, presso qualche amico spirituale dei frati, perché per mezzo di lui venga usata come gli sembrerà bene, per le loro necessità in luogo e tempo opportuno. A quest'ultimo anche $i$ frati sempre per necessità imminenti potranno far ricorso, soprattutto se si diporta con negligenza o non conosce le loro necessità. ${ }^{211}$
\end{abstract}

Por um lado, devido à expansão numérica e geográfica, o controle de recrutamento dos novos frades não poderia ficar inteiramente centralizada na figura do ministro geral conforme a Regra de $1223^{212}$, por isso Gregório IX estendeu a licença de delegar este ofício aos demais ministros provinciais desde que o ministro geral concedesse tal licença; ele podia tanto conceder como negar. Assim, os ministros provinciais podiam receber os novos membros mas não tinham permissão para conceder a licença a outros ministros provinciais. Também pesava a decisão no fato de que a Igreja direcionava um novo papel à Ordem franciscana; cada vez mais as missões ou pregações ocorriam em sedes estáveis e o conteúdo das pregações se restringia ao

\footnotetext{
211 IDEM, Ibidem.

${ }^{212}$ Et nullus fratrum populo penitus audeat praedicare, nisi a ministro generali huius fraternitatis fuerit examinatus et approbatus, et ab eo officium sibi praedicationis concessum. Regula Bullata, capítulo 9, 3. MENESTÓ, Fontes franciscani..., p. 178.
} 
encargo exclusivo do ministro geral; por isso Gregório $I^{213}$ adverte que não havia necessidade de exame; os frades que fossem instruídos na faculdade teológica e no ofício da pregação. Ademais, não seria mais possível acolher os novatos nos Capítulos gerais, mas em uma outra forma de representação, influência essa do modelo constitucional adotado pelos Cisterciensis e Dominicanos.

\begin{abstract}
Alla questione rispondiamo come segue: questa facoltà il ministro generale non la può concedere a persone lontane, ma quelli che sono ritenuti bisognosi di esame, siano mandati da lui, oppure convengano assieme ai ministri provinciali al capitolo generale per questo motivo. Per quelli invece che non hanno necessità di esame, perché sono stati istruiti in una facoltà teologica e nell'ufficio della predicazione, se hanno maturità di età e gli altri requisiti del caso, possono nel modo che è stato detto predicare al popolo, eccettuati quelli a cui il ministro generale lo negasse.

In settimo luogo, si dubita dai frati se i vicari dei ministri provinciali, che li sostituiscono mentre essi si recano al capitolo generale, possano ricevere qualcuno all'Ordine o allontanare chi è già stato recevuto. Rispondiamo che non lo possono, per la ragione che questa facoltà non l'hanno neppure i ministri provinciali se non viene data loro a questo riguardo una licenza speciale, e ad essi il ministro generale come la può concedere così può anche negarla. E poiché, secondo la Regola, la facoltà di ammettere frati all'Ordine può essere conferita solo ai ministri provinciali, molto meno hanno potestà di conferirla ad altri i ministri provinciali ai quali soltanto e non ad altri è conferita"214.
\end{abstract}

Por outro lado, a influência dos outros modelos monásticos tradicionais acima mencionados começou a penetrar na Ordem, inclusive na discussão da pobreza. A questão entre propriedade e uso das coisas de maneira pobre foi adquirindo uma complicada instituição jurídica que não se restringiu à distinção simples entre propriedade e uso, houve uma complexa construção de conceitos com precisões jurídicas mais complexas e as modalidades às quais os frades deveriam ater-se em todas as situações em que eles se viam envolvidos na relação com bens materiais. Essas relações foram destrinchadas em conceitos em torno da propriedade (proprietas), posse (possessio), usufruto (ususfructus), direito de uso (ius utendi) e simples uso de fato (simplex usus facti). Deste modo, o problema da interpretação da pobreza da Regra apostólica não ficou restrito a uma discussão interna da Ordem Mendicante e

${ }^{213}$ Neste momento, para a Igreja, havia um grande interesse em expandir a Ordem franciscana.

${ }^{214}$ Bolla "Quo elongati" di Gregorio IX. In: CAROLI, Ernesto (org.) Fonti Francescane, nuova edizione...., p. 1725. 
Gregório IX não foi o único papa a interpretar a Regra de Francisco e a negar o valor legislativo ao Testamento. Como resultado, iniciou-se uma contenda doutrinal que se prolongou por decênios, discussão que se transformou num verdadeiro processo jurídico a partir de $1230^{215}$. A proposta de Gregório IX era de encerrar a discussão da interpretação da norma franciscana e negar o estatuto jurídico ao Testamento, porém, parece-nos que o efeito foi justamente o inverso. Com a promulgação da Quo elongati nasceu uma discussão teórica sobre a pobreza jurídica dos preceitos normativos franciscanos e o Testamento continuou a ser objeto de agregação ou negação.

Assim, um dos aspectos mais importantes desta discussão que se observa foi um esvaziamento da ideia de pobreza absoluta na prática, que foi logo identificado como um sinal mais tangível da herança de Francisco e, depois, como a característica peculiar da Ordem. Como vimos, as questões apresentadas pelo papa em 1230 abriram um viés sobre outros tantos aspectos da vida e pobreza da Ordem, que seria modificado rapidamente ao longo do século XIII. O termo definidor desta nova mudança é a "clericalização". O processo de adaptação da Regra às nove exigências da vida dos frades acabou por iniciar um novo período de metamorfose dentro do movimento Franciscano. Por isso, concordamos neste aspecto com Malcolm Lambert, o ano de 1230 representou a última chance da Ordem de retornar para o modo de vida de Francisco e companheiros, modo esse bloqueado pela Quo elongati devido ao peso da procedente decisão judiciária e da legislação que era tão notável para ser possível ou praticável ${ }^{216}$, o que justifica em parte a formulação das constituições papais posteriores, mais completas pelo fato de abrangerem uma interpretação pormenorizada da Regra.

Para além da sanção definitiva de invalidade jurídica do Testamento, os nove aspectos acerca dos pontos duvidosos da Regra Apostólica causaram novos embates ao movimento. A partir da Quo Elongati, parece-nos que o conceito de pobreza dentro da Ordem não foi mais o mesmo, já que Gregório IX trouxe uma reinterpretação da norma; indo para além da distinção simples entre proprietas e usus, ele contribuiu para o início de um desenvolvimento

${ }^{215}$ HARDICK. Lothar. "Pobreza, pobre". In: CAROLI, Ernesto (Org.). Dicionário Franciscano. Petrópolis: Vozes, 1999, p. 595.

${ }^{216}$ LAMBERT, Malcolm. Povertà Francescana. La dottrina dell'assoluta povertà di Cristo e degli apostoli nell'Ordine Francescano (1210-1323). Milão: Edizioni Biblioteca Francescana, 1995. 
jurídico precursor em relação a paupertas, cada vez mais complexo porque os papas sucessores sempre tiveram na Quo elongati uma referência e ponto de partida.

Enfim, a Ordem Franciscana representou para Gregório IX, uma ocasião para recuperar uma identidade compatível com a sociedade do século XIII e dentro da perspectiva de um "regimen christianum" fundado sobre a diretriz da Igreja de Roma. Assim, um largo espaço foi deixado às Ordens mendicantes para administrar as relações entre a sociedade e a lgreja. Por isso, a importância das interpretações pontifícias no tocante à pobreza não permaneceram somente no âmbito interno da Ordem e a pobreza exposta na Norma era uma condição necessária para se atingir a perfeição evangélica.

Como já mencionamos, o nascimento da questão Regra-Testamento iniciou com a promulgação da bula Quo Elongati, visto que Gregório IX considerou que as "últimas vontades ou disposições" de Francisco não tinham um caráter preceptivo aos frades, concluindo que não deveriam ser observadas junto à Regra. Para Edith Pásztor ${ }^{217}$, a primeira declaração papal foi a mais decisiva, sem dúvida, ao negar a validade jurídica do Testamento. É claro que a interpretação do papa não foi aceita unanimamente pelos frades ao longo da história da Ordem, principalmente pelos "rigoristas, que tentaram restituir o Testamento como um opúsculo de obrigatória observância e como algo mais próximo do franciscanismo das origens e da doutrina da absoluta pobreza, o que justifica em parte a continuidade e perpetuação da discussão por meio das constituições papais com o objetivo de afirmar ou não a Carta Quo elongati e dar uma nova interpretação à Regra na medida em que os problemas internos da Ordem requisitavam; as mais diferentes propostas ou soluções apareceram nas décadas seguintes. Depois da Quo elongati, a identidade entre o evangelho e a Regra franciscana veio a ser delimitada com as precisões papais do ponto de vista jurídico por meio de resoluções que permaneciam mais no plano teórico do que prático.

\subsection{As mitigações de 1245 de Inocêncio IV (1243-1254): um novo conceito de pobreza}

217 PÁSZTOR, Edith. Francesco d'Assisi e la "questione francescana". Assis: edizioni Porziuncola, 2000, p. 329. 
O papa seguinte a trazer uma nova interpretação à pobreza da Regra foi Inocêncio IV (1243-1254) que promulgou, no dia 14 de novembro de 1245, a declaração Ordinem vestrum, que trouxe mudanças bastante opostas a Gregório IX e, de uma certa forma, comprometeu a pobreza franciscana. Segundo a Enciclopedia dei Papi ${ }^{218}$, Sinibaldo Fieschi nasceu no ano de 1190 em Lavagna (Genova). Entre os anos de 1213 e 1223 estudou direito em Bolonha, onde obteve o título de "magister" e de subdiácono papal, período em que começou a estabelecer relações pessoais com a Cúria Romana e com o futuro papa Gregório IX, ainda cardeal Hugolino de Óstia, sendo seu secretário pessoal.

Antes da rebelião da Marca de Ancona, a partir de 1239, houve uma transformação legislativa na Ordem, apesar da escassez das fontes como nos aponta Falbel ${ }^{219}$. No ano de 1239, abriu-se uma nova fase constitucional na história da Ordem. Tomás de Eccleston (ca. 1215?-1258?) falava de uma "reforma" na Ordem dos Menores, sobretudo porque o generalato conturbado $^{220}$ de frei Elias (1232-1239) havia contribuido em muito para a necessidade de tais mudanças institucionais. No Capítulo geral de 1239 iniciouse um novo processo de clericalização retomado e emanado por uma série de promulgações das primeiras constituições com o objetivo de regular a disciplina interna e de ditar as normas de aplicação das disposições da Regra. Pediu-se, no Capítulo de Montpellier, a todas as Províncias da Ordem que redigissem um comentário à Regra franciscana. Destes comentários conserva-se o dos quatro mestres de teologia de Paris que propuseram soluções através de uma Expositio sobre alguns aspectos da normativa indicando a necessidade de uma interpretação apostólica. Foram os autores, Alexandre de Hales (1183-1245), João de la Rochelle, Eudes de Rigaud (ca. 1200-1275) e Roberto de Bassée.

As principais discussões gravitaram em torno do acolhimento dos postulantes e do exame do ofício da pregação. A Regra prescrevia que a faculdade de receber os novos membros poderia ser concedida ao ministro

\footnotetext{
${ }^{218}$ BAGLIANI, Agostino Paravicini. "Innocenzo IV". In: ENCICLOPEDIA dei Papi. Roma: Istituto della Enciclopedia italiana, 2000, 2v, p. 385.

${ }^{219}$ FALBEL, N. Op. cit., pp. 79-103.

${ }^{220}$ Elias foi acusado de enriquecimento ao arrecadar uma alta quantia em dinheiro para a Basílica que albergaria o corpo do Santo Francisco, além dos problemas da transladação do corpo do Santo, entre outros motivos, ele foi deposto segundo as hagiografias.
} 
geral e provinciais, e somente o ministro geral poderia avaliar o conteúdo dos candidatos à pregação, exceto os casos em que o frade tivesse a faculdade teológica e o ofício de pregador. Com a Quo elongati, restringiu-se essa possibilidade de exame da pregação ao ministro geral conforme já mencionamos. No entanto, em 1240 e 1241, Gregório emitiu dois privilégios segundo os quais os ministros provinciais também poderiam examinar os candidatos à pregação e delegar a outros frades a função de acolher na Ordem os postulantes devido ao aumento numérico dos frades. Assim, os quatro mestres de Paris examinaram tal situação e tomaram posição. Por um lado, não era mais possível ater-se às interpretações restritivas da Quo elongati e por outro lado, muitos frades entenderam que os privilégios papais constituiam um verdadeiro relaxamento da pobreza da Regra e os frades dirigentes deveriam restabelecer a Ordem.

O sucessor de Elias ${ }^{221}$, Alberto de Pisa teve uma carreira rápida. Foi ministro provincial da Toscana, Marca de Ancona, Alemanha, Espanha, Bolonha, Hungria, Inglaterra e tornou-se ministro geral em 1239, permanecendo no cargo até 23 de janeiro de 1240. Neste curto generalato, corrigiu os excessos de seu predecessor, principalmente nas províncias transalpinas, onde os erros e os desvios haviam sido maiores. Com a eleição de Haimo de Faversham (1240-1244), a oposição a Frei Elias aumentou. Haimo não conheceu Frei Francisco e liderou a oposição contra Elias. Sua administração foi muito ativa, visitava constantemente as províncias, corrigindo os erros no próprio local. Em relação à Regra, muitas novas constituições foram promulgadas, o ministro geral atendeu ao pedido dos frades para que não houvesse modificação na Regra.

De 1239 até 1244, assistimos a uma fase de intensa elaboração constitucional. Mesmo assim, Crescêncio de lesi (1244-1247) não conseguiu apaziguar as disputas internas da Ordem e, no generalato seguinte, de João de Parma (1247-1257) os conflitos entre os seguidores de Frei Leão e os de Frei Elias acirraram-se na Ordem.

${ }^{221}$ Como já foi dito, ele foi deposto, depois de um generalato turbulento, Gregório IX exigiu que Frei Elias prestasse obediência ao novo ministro geral e inibiu qualquer tentativa de retorno dele ao cargo. 
Em 25 de junho de 1243, Sinibaldo foi eleito papa depois de uma longa vacância da Sé apostólica, circunstância em que estava bastante adoecido. Inclusive Frederico II participou da eleição do novo papa e aceitou a proposta de paz com o novo eleito; assim o acesso à cidade de Roma foi liberado, mas o imperador retirou os seus embaixadores de Roma. Assim, o papa Inocêncio IV entrou em Roma no dia 20 de outubro de $1243^{222}$. Antes da promulgação da Ordinem vestrum, Inocêncio IV convocou o Concílio de Lyon, que se iniciou no dia 26 de junho de 1245. O pontifíce pronunciou um discurso sobre "as dores do papa" e apontou os problemas daquele momento: a corrupção moral, a questão dos sarracenos, o cisma da Igreja grega, os problemas do Império latino do Oriente, a ameaça dos tártaros, e, naturalmente, a perseguição da Igreja por parte do Imperador. Novamente Inocêncio IV renovou as acusações tradicionais da violação do juramenteo, de suspeita de heresia e de sacrilégios, como havia feito o seu antecessor ao Imperador Frederico II. Pela primeira vez, após o Concílio de Latrão de 1215, o cenário conciliar estava ocupado exclusivamente por problemas políticos, e não no tocante à disciplina ou à pastoral, como a reforma da Igreja e o combate a heresia. Se o IV Concílio Lateranense se impôs por seu poderoso programa legislativo, o Concílio de Lyon se dedicou sobretudo aos problemas políticos.

Os problemas políticos que Inocêncio IV estava enfrentando não justificavam tais "desvios" na interpretação da pobreza franciscana. O papa canonista que promulgou a Carta Ordinem vestrum no dia 14 de novembro de 1245 trouxe um novo conceito de pobreza franciscana. Inocêncio IV foi um especialista em direito canônico, mas o centro de sua preocupação e da Cúria Romana naquele momento não era pastoral ou disciplinar. Para Andrea Tabarroni, a proposta de Inocêncio IV gravitava apenas em torno da ideia de resolver os pontos duvidosos e obscuros da Regra. Ele não apresentou, ao menos formalmente, a Ordinem vestrum como fruto de sua interpretação pessoal. Entretanto, sabemos que "os pontos duvidosos e obscuros da Regra" transformaram-se num topos de justificativa para uma nova interpretação. Diferentemente de Gregório IX, o papa Inocêncio IV não fez nenhuma referência ao tópos da "verdadeira intentio" de Francisco ou às suas finalidades

${ }^{222}$ BAGLIANI, Agostino Paravicini. “Innocenzo IV”. In: ENCICLOPEDIA..., p. 386. 
gerais. A Ordinem vestrum tinha somente aspectos e características formais de um ato disciplinador ${ }^{223}$.

De acordo com esta nova constituição, os frades poderiam contar com o recurso do dinheiro, inclusive para evitar incômodos (commoda fratrum); o núncio (embaixador do papa) poderia guardar o dinheiro e comprar as coisas para a necessidade dos frades; o direito à propriedade de todos os bens móveis e imóveis, concedidos aos frades, passaria para a Igreja Romana definitivamente se os benfeitores não reservassem para si mesmos tal direito $^{224}$. Assim, o papa definiu que todos os bens pertenciam à Santa Sé e ao mesmo tempo alargou a questão do usus, trazendo novas sutilezas jurídicas com o commoda fratrum e ius utendi; novamente o principal problema consistia na aplicabilidade da normativa franciscana no cotidiano dos conventos, o que na prática acabou direcionando-se ao monaquismo tradicional e a discussão permaneceu no plano teórico.

Antes de mais nada, em relação à Ordem dos Frades menores, Inocêncio IV acompanhou muito de perto os acontecimentos e interferiu diretamente nos assuntos principais, demonstrando preocupação pelo destino da Ordem Franciscana, mas não muito entendimento sobre a construção da norma no movimento Franciscano. Desde o início do seu pontificado, atuou no sentido de impedir que os seguidores de frei Elias, alguns conventuais, fizessem retornar o ex-ministro geral ao governo da Ordem. Inocêncio IV emitiu várias bulas relativas à explicação da Regra franciscana ou a questões relacionadas aos conventos franciscanos femininos. São um testemunho de sua atuação nos negócios internos da Ordem mendicante a concessão de privilégios e mitigações, solicitando concessões quando julgava necessárias e oportunas para a vida e apostolado dos frades, como convinha aos interesses da Cúria Romana, além de seu impetuoso envolvimento e interferência constante com correções formais e organizacionais em relação às "Pobres Damas".

Posteriormente, o papa percebeu a debilidade do generalato de Crescêncio de lesi (1244-1247) e o erro cometido na escolha dele pelos frades, visto que as lutas internas se intensificaram na Ordem, o que já ameaçava a

\footnotetext{
${ }^{223}$ TABARRONI, Andrea. Op. cit., p. 111.

${ }^{224}$ FALBEL, Nachman. Os Espirituais franciscanos..., p. 91.
} 
integridade da instituição franciscana. $\mathrm{Na}$ verdade, entendemos que a política de Inocêncio IV caminhava no sentido de apaziguar ambos os lados, favorecendo os conventuais e tentando integrar os "Rigoristas" na Ordem.

A Ordinem vestrum não foi a única bula de Inocêncio IV a fim de resolver os problemas internos da Ordem franciscana. Exemplo disso foi no dia 19 de agosto de 1247, quando o papa canonista emitiu a bula Quando Studiosius, no qual autorizava os Frades menores a fazerem a opção entre um "procurador" ou "síndico" em cada província, em nome da Santa Sé, para administrar os bens dos religiosos, uma vez que era difícil recorrer, em casos urgentes, ao protetor da Ordem. Mais tarde, esses poderes dados ao "procurador" foram confirmados pelos papas Alexandre IV (1254-1261), Clemente IV (1265-1268) e Martinho IV (1281-1285). Em 1253, Inocêncio IV, com as bulas "Decet et Expedit", de 10 de julho e "Dignum Existimamus", de 16 de julho de 1253, autorizou os frades a receberem oferendas em dinheiro e ornamentos sacros de alto valor oferecidos à basílica, "não obstante os estatutos da Ordem serem contrários às proibições do ministro geral ou provincial"225.

Como já foi dito, a declaração Ordinem vestrum de 14 de novembro de $1245^{226}$ comprometeu o conceito de pobreza da Regra franciscana ao fazer um número tão grande de mitigações. Diferente da Quo Elongati, a interpretação de Inocêncio IV distanciava-se em muito das disposições da Regra. Então, o papa canonista justificava a nova constituição papal alegando que a bula de Gregório IX estava incompleta e ele iria clarificá-la através de uma perfeita interpretação.

Vi sono nella vostra Regola alcuni punti dubbi e poco chiari che confondono il vostro animo per una certa perplessità e sono di impedimento all'intelletto per la loro complicata difficoltà. II nostro predecessore papa Gregorio, di felice memoria, ne há esposti alcuni e ne ha dato una chiarificazione non completa. Per questo noi, volendo rimuovere completamente da essi l'oscurità, chiarificandoli attraverso una perfetta interpretazione, e con la stessa sollecitudine eliminare

\footnotetext{
${ }^{225}$ FALBEL, N. Op. cit., p. 91.

${ }^{226}$ A bula suscitou uma reação interna na Ordem franciscana assim que foi promulgada. No Capítulo geral de Metz em 1254 ocorreu a suspensão da aplicação da Ordinem vestrum e a retificação deu-se seis anos depois nas constituições gerais do Capítulo geral de Narbona, ninguém deveria utilizar as afirmações de Inocêncio IV porque destoava as decisões tomadas por Gregório IX na Quo elongati.
} 
del tutto dal vostro cuore lo scrupolo dell'ambiguità con la certezza di un'esposizione più completa. ${ }^{227}$

Primeiramente, os frades poderiam recorrer ao uso de dinheiro, não somente no caso de manifesta necessidade (de necessitate, por exemplo, no caso de frades enfermos) mas também se com isto pudessem ser evitados incômodos (commoda fratrum). Em segundo lugar, não apenas o "amigo espiritual", mas também o nuntius (embaixador do papa) poderia receber e guardar dinheiro para a necessidade dos frades. Por último, o direito de propriedade de todos os bens móveis e imóveis, concedidos aos frades em uso simples, passariam para a Igreja Romana se os benfeitores não reservassem para si mesmos tal direito com antecedência ${ }^{228}$.

\begin{abstract}
Benché nella stessa Regola sia proibito che $i$ frati ricevano in nessun modo denaro o pecunia personalmente o per mezzo di altri, tuttavia, se essi vogliono comprare una cosa necessaria o utile, oppure fare il pagamento per una comperagià avvenuta, possono indicare 0 l'incaricato di colui dal quale si compra la cosa, o qualche altro, a coloro che volessero far loro l'elemosina (a meno che preferiscano pagare loro stessi personalmente o per mezzo dei propri delegati). $\mathrm{E}$ l'incaricato così presentato dai frati, non è il loro, sebbene sia da loro presentato, ma piuttosto di colui per la cui autorità fa il versamento, o di colui che lo riceve; e (se dopo il pagamento della compera, rimanga presso di lui qualche resto di tale elemosina) possono anche i frati ricorrere a lui lecitamente per le loro esigenze necessarie e utilità. Se poi per le altre esigenze e utilità dei frati venga nominato o presentato qualcuno, può egli conservare come padrone l'elemosina affidatagli, o depositarla presso un amico spirituale o familiare dei frati nominato o anche non nominato da loro, dal quale sia dispensata a tempo e luogo secondo le esigenze necessarie e l'utilità dei frati, come essi crederanno utile, o sia trasferita a un'altra persona o in altri luoghi: a costoro anche $i$ frati potranno ricorrere con sicura coscienza per tali esigenze necessarie o utilità, specialmente se quelli siano stati negligenti o quelle loro necessità e disagi abbiano ignorato. ${ }^{229}$
\end{abstract}

Como já mencionamos, a longa carta Ordinem vestrum visava a contribuir para o esclarecimento das "dúbia et obscura quae in Regula

\footnotetext{
${ }^{227}$ O grifo é nosso para ressaltar os termos usados por Inocêncio IV. Bolla "Ordinem vestrum" di Innocenzo IV. In: CAROLI Ernesto (org.) Fonti Francescane, nuova edizione. Scritti e biografie di san Francesco d'Assisi. Cronache e altre testimonianze Del primo secolo francescano. Scritti e biografie di santa Chiara d'Assisi. Testi normativi dell'Ordine Francescano Secolare. Padova: Editrici Francescane, 2004, p. 1727.

${ }^{228}$ HARDICK, Lothar. "Pobreza, pobre". Op. cit., p. 595.

${ }^{229} \mathrm{Na}$ Quo elongati se falava somente da aquisição das coisas necessárias e afirmava "daquele para qual autoridade", muda sutilmente na Ordinem vestrum "para aquele no mandato do qual", além disso, na Quo elongati o uso das coisas deveriam se limitar as "necessidades iminentes". O grifo é nossa para enfatizar o uso dos termos principalmente de "necessidade" e "utilidade". Bolla "Ordinem vestrum" di Innocenzo IV. In: Op. cit., pp. 1728 e 1729.
} 
continentur" e sancionar o valor canônico de algumas decisões dos Capítulos gerais, ou seja, assim como a Quo eloganti, a Ordinem foi uma resposta dada pelo papa a pedido dos frades. Além disso, nesta constituição papal é reafirmada a norma eleitoral segundo a qual podiam participar do capítulo para a eleição do ministro geral os ministros provinciais e um custódio de cada Província, que tinha a representação eleitoral ("vox") de seus "pares". Cada vez mais cresciam na Ordem a burocracia e a hierarquia em proporções consideráveis ao número de membro; quanto mais frades, mais cargos e mais descentralização ${ }^{230}$.

No entanto, a principal função da Carta Ordinem vestrum de 1245 refere-se a indicações sobre os problemas da pobreza, que foram levadas a uma considerável mitigação das orientações e dos vínculos pauperistas contidos na Regra. A Carta Quo Elongati, de Gregório IX, de 1230, não se distanciava das disposições da Regra no que se referia à pobreza além daquilo que fosse estritamente necessário, já a Ordinem vestrum segue abaixo com um "desvio", o uso de lugares e de casas.

Poiché nella Regola è espressamente contenuto che $i$ frati non si approprino di nulla, né di casa, né di luogo, né di alcun'altra cosa, dichiariamo inoltre che non possono avere proprietà in comune 0 individualmente, ma l'Ordine abbia l'uso dei luoghi, delle case, degli utensili, dei libri e di quei beni mobili che è licito possedere; i frati poi ne usino secondo quanto hanno pensato di disporne il generale $\mathrm{o} i$ ministri provinciali. Né debbono essere venduti luoghi, case o beni mobili simili, né possono essere commutati fuori dell'Ordine o alienati in qualunque modo, da qualsiasi persona donati, venduti, permutati ad uso dei frati, sia in qualunque modo siano stati trasferiti o lo saranno, se la Sede apostolica o il cardenale della santa Chiesa, che vi è stato dato pro tempore come protettore, non ne abbia dato l'autorità 0 l'assenso al generale o ai ministri provinciali: poiché il diritto, la proprietà e il dominio di tali beni sia immobili che mobili (esclusi quelli su cui consti che i donatori o i traslatori si siano riservati espressamente la proprietà e il dominio) spettano alla Chiesa senza mediatori: è notorio che ad essa sottostanno del tutto direttamente le case e i luoghi predetti con le Chiese e le altre pertinenze nelle cose sia spirituali che temporali (tutti beni che noi riceviamo in diritto e proprietà del beato Pietro). ${ }^{231}$

Desta forma, a bula de 1245 provocou a reação dos chamados seguidores de Frei Leão, ou zelantes, os futuros "Espirituais" franciscanos, dissidência que defendia uma pobreza mais rigorosa na prática e observância

${ }^{230}$ MERLO, Grado G. Op. cit., p. 112.

${ }^{231} \mathrm{O}$ grifo é nosso para enfatizar a decisão de Inocêncio IV de transferir em definitvo os bens móveis e imóveis da Ordem Franciscana para a Santa Sé. IDEM, Ibidem, pp.1729-1730. 
mais rígida da Regra de 1223. Por isso, não faltaram críticas à declaração de Inocêncio IV. Os seguidores de Frei Leão sustentavam com firmeza sua posição e cada vez mais eram convencidos da obrigatoriedade do Testamento e da observância literal da Regra sem glosas ou declarações, considerando as atenuações de Inocêncio IV como um decaimento do fervor inicial da primeira geração menorita. Já no Capítulo geral de Genova em 1251, a maioria dos frades decidiu "fere totium capitulum" a renúncia ao indulto de receber dinheiro através dos "procuradores" ou "núncios". Foi levantada a proposta de suspender o que consideravam que poderia se transformar em abuso a "commoda fratrum" (comodidades estendida para todos os frades); apesar de não gerar grandes polêmicas, criou problemas ao grupo que queria suspender também as concessões referentes a "necessitates" dos frades, e que haviam sido concedidos à Ordem a fim de favorecer o seu desenvolvimento e tornar mais ágeis e eficazes as atividades apostólicas.

No entanto, a decisão mais importante sobre a constituição Ordinem vestrum aconteceu no Capítulo de Metz de 1254 por meio de uma resolução de que a Ordem dos Menores renunciaria ao privilégio outorgado por Inocêncio IV, pela constituição Ordinem vestrum, autorizando os frades a se dirigirem ao nuntius, isto é, ao delegado ou a seu substituto, já estabelecido pela bula Quo Elongati, de 1230, não somente em caso de primeira necessidade mas também para procurar as simples comodidades da vida, pro commodis. O ministro geral João de Parma tomou importantes decisões de renúncia aos privilégios que Inocêncio IV havia concedido em matéria de administração dos bens da Ordem e do uso do dinheiro ${ }^{232}$. Assim, a decisão do Capítulo de Metz favorecia a vontade dos "rigoristas", que viam em todos esses privilégios concedidos pela Igreja uma ameaça ao princípio de pobreza primitiva da Ordem. Na verdade, Inocêncio IV acabou criando um novo conceito de pobreza ao discutir algumas medidas mais práticas, o que difere em muito do conceito de pobreza exposto na Regra de 1223.

Além disso, o Capítulo de Metz resolveu que os Capítulos gerais se realizariam alternadamente nas províncias cisalpinas e nas transalpinas, tentativa do ministro geral João de Parma (1247-1257) de por fim às divisões

${ }^{232}$ MERLO, Grado G. Em nome de São Francisco..., p. 116. 
existentes na Ordem e trazer a paz entre ambas as partes. Ele visitava pessoalmente várias Províncias, acolheu a religiosidade dos leigos e as exigências materiais dos frades, e também os "benfeitores da Ordem", mediante cartas, autenticadas com o próprio selo de ministro geral, enviadas aos requerentes que manifestassem sérias intenções de entrar em formal relacionamento com os Frades menores. Conforme Merlo, João de Parma era um ministro geral bastante sensível a caracteres e exigências da especificidade franciscana, tanto no próprio comportamento diário, quanto nas difíceis decisões de governo e de defesa da "pobreza" ${ }^{233}$.

Para além do Capítulo geral de Metz, o frade provençal Hugo di Digne (?-1285), na sua Expositio ${ }^{234}$, utilizou ao menos uma vez o texto da Ordinem vestrum com o objetivo de reforçar a apresentação da decisão de Inocêncio IV não como uma interpretação mas como uma medida disciplinadora que possibilitou aos ministros provinciais adquirir autoridade ordinária e delegável, de receber na Ordem os novos membros. Esse comentário de Hugo di Digne depois foi usado por Boaventura na obra Epistola de tribus quaestionibus, na qual uma série de argumentações de que a recepção de dinheiro via intermediários, a utilização de casas e terrenos, a introdução do trabalho acadêmico e o abandono do trabalho manual, não representariam uma traição à Regra de Francisco e às intenções dele. Assim, à medida que a discussão em torno do relaxamento da pobreza normativa e da organização da Ordem evoluía, cresciam as divisões partidárias no interior da Ordem. As tensões internas já existiam desde a época de vida de Francisco, mas a cada constituição papal ou Expositio de um frade sobre a Regra e Testamento acirravam-se os conflitos internos ${ }^{235}$.

Segundo Grado Merlo aos frades era fornecido o indispensável fundamento institucional (e ideológico) que lhes consentira defender a "pobreza", à qual continuavam como referência da própria identidade de Menores e da sua mendicância; uma "pobreza" que a realidade concreta de cada dia punha em discussão: como aplicar a norma no cotidiano dos frades? Isso estava no centro dos debates e das controvérsias dentro e fora da Ordem.

\footnotetext{
${ }^{233}$ MERLO. Op. cit., p. 115.

${ }^{234}$ Primeira obra que podemos efetivamente definir como uma expositio da Regra de 1223. Ela foi escrita entre os anos de 1245 e 1255.

${ }^{235}$ LAMBERT, Malcolm. Op. cit., pp. 115 e 116.
} 
Sabemos que ao longo do século XIII ocorreram "refinadas e ardentes reflexões sobre a pobreza em debates calorosos, provocando um lento embora inexorável deslizamento da pobreza vivida para a pobreza pensada, já que o ponto de referência não era mais a experiência religiosa de Francisco, mas a codificação da experiência como se encontrava na Regra (e em outros textos franciscanos de apoio), mediante as expositiones, cuja autenticidade (ou a inautenticidade) era estabelecida pelo poder eclesiástico". Em resumo, a "questão da pobreza" tornou-se uma "interpretação da pobreza" da Regra bulada de 1223 como caráter peculiar de uma formação religiosa que, baseada na própria "autenticidade evangélica", reivindicava uma providencial e peculiar função na "história" do testemunho cristão e, portanto, uma eminente presença eclesial e eclesiástica ${ }^{236}$. O problema consistia em como aplicar "a questão da pobreza" no sentido prático; qual sentido era permitido pela Igreja naquele momento?

No generalato de João Buralli de Parma (1247-1257), já ficou claro que a Ordem não seguiria a bula de Inocêncio IV, rejeitada no Capítulo geral de $M{ }^{237}$ em 1254, por estar em contradição com a bula de Gregório IX. João de Parma dava pouco valor às leis ou à legislação como meio de disciplinar e reger a vida dos Menores; apoiava-se fundamentalmente na Regra e no Testamento de São Francisco, conseguiu renovar todos os privilégios da Carta de Gregório IX, também reforçado no generalato de Boaventura de Bagnoregio (1257-1274) no Capítulo geral de Narbona em 1260. Dois anos depois foram renovados todos os precedentes privilégios da Ordem. De fato, as controvérsias a respeito da concepção de pobreza não favoreceram a observância, mas um acirramento das tensões internas ${ }^{238}$.

Como bem nos coloca Edith Pásztor, a declaratio de Inocêncio IV representou um empenho hermenêutico para resolver os problemas internos levantados pelas diferenças entre o modo de viver prescrito da Regra e as transformações que eram verificadas em 1245, algumas das quais já tinham sido reunidas e confirmadas pelo papa. A data de 1245, inserida entre o convite disposto por Crescêncio de lesi de reunir um novo material relativo à

\footnotetext{
${ }^{236}$ MERLO. Op. cit, p. 112.

${ }^{237}$ No Capítulo Geral de Metz foi aprovada a resolução de que a Ordem renunciaria ao privilégio outorgado por Inocêncio IV, pela Constituição Ordinem Vestrum.

${ }^{238}$ HARDICK, "Pobreza, pobre". Op. cit., p. 595.
} 
vida de Francisco (1244) e a compilação por parte de Tomás de Celano da sua Memoriale in desiderio animae (1246-1247), num momento crítico, na qual se advertia sobre a necessidade de reconstruir um novo modelo do fundador e diferente da imagem deixada na Vita I de $1228^{239}$. Antes do fim do I Concílio de Lyon, a bula Ordinem vestrum promulgada pode ser vista como uma resposta ao modo de viver dos cardeais e, principalmente, a querela Parisiense na qual os franciscanos se engajaram, o que acarretou uma série de problemas para a Ordem, sobretudo em relação à pobreza e à difusão do joaquimismo ${ }^{240}$.

No fim do papado de Inocêncio IV a Ordem estava totalmente envolvida na repressão anti-herética, quando os frades assumiram o cargo de inquisidores e multiplicaram o número de cátedras arquiepiscopais e episcopais em várias partes da cristandade, apesar de perderem todos esses privilégios antes obtidos contra os direitos paroquiais e diocesanos com a bula Etsi animarum, de 21 de novembro de 1254, inclusive a limitação de uma única cátedra de ensino aos "mendicantes" (os dominicanos e franciscanos disputariam uma única cátedra), o papa resolvia o conflito entre os mestres seculares e os mendicantes (1253-1259), impondo restrições aos mendicantes $^{241}$. Enfim, no último ano do pontificado de Inocêncio IV, nos primeiros meses de 1254, o papa canonista chegou a determinar as áreas de respectiva competência aos inquisidores provenientes das fileiras da Ordem dos Pregadores e àqueles que seriam escolhidos no meio dos Menores.

Enfim, com a Ordinem vestrum, o conceito de pobreza da Ordem foi praticamente comprometido devido a um número tão grande de mitigações das orientações e dos vínculos pauperistas contidos na Regra. Diferente da Quo Elongati de 1230 de Gregório IX, a interpretação jurídica de Inocêncio IV distanciava-se em muito das disposições da norma franciscana, causando controvérsias acaloradas. Entre outras coisas, estava a polêmica da possibilidade de os frades recorrerem ao dinheiro, não só em autêntica necessidade (de necessitate), mas também para evitar-lhes incômodos (commoda fratrum), aportando modificações sobre quase todos os capítulos da

\footnotetext{
${ }^{239}$ A maioria das legendas compostas entre os anos de 1220 e 1230 faziam elogios demasiados a Frei Elias, o que não agradava o ministro geral Frei Haimo que havia liderado oposição a Elias e também porque não favorecia a visão institucional que o novo ministro geral queria dar à Ordem.

240 PÁSZTOR, Edith. Op. cit., pp. 332 e 333.

${ }^{241}$ MERLO, Grado G. Op. cit., p. 114.
} 
Regra. No tocante à propriedade, sobretudo, estava a atribuição à Sé apostólica do direito de propriedade dos bens móveis dos frades (se por acaso o doador não se reservasse o "dominium"), a quem era deixado o "usus", os frades possuiriam apenas o uso simples das coisas, confirmando assim a proibição à propriedade, mas não acenou a alguma moderação a respeito do uso das coisas. Em suma, aos franciscanos foi destinado um novo conceito de fundamento institucional e ideológico da pobreza.

Após o generalato de João de Parma, o ministro geral seguinte, Boaventura de Bagnoregio ${ }^{242}$ (1257-1274) iniciou o seu generalato participando do julgamento do processo de acusação de heresia do seu antecessor (João de Parma), que foi acusado de ser adepto das ideias joaquimitas. Não é tão por acaso que Frei Angelo Clareno classificou o generalato de Boaventura como o período da quarta perseguição ou tribulação aos seguidores de Frei Leão. Assim, concluimos que a partir deste período o limite entre ser dissidente ou não da Ordem franciscana em relação à interpretação da pobreza era bastante tênue, ora determinado pelo ministro geral, ora pelo papado.

\section{3. $O$ ano de 1279: Nicolau III (1277-1280) e a anulação das declarações anteriores sobre a Regula}

Segundo a Enciclopedia dei Papi ${ }^{243}$, Giovanni Gaetano Orsini nasceu em Roma no ano de 1216. Por ser o segundo filho do casal Orsini provavelmente desde a sua infância estava destinado à vida religiosa. Teve uma carreira eclesiástica atuante. Foi cônego de York, Soissons e Laon; também foi do canonicato da Igreja Romana de São Lorenzo em Damásio e de São Crisógono. Em 28 de maio de 1244 foi elevado ao cargo de subdiácono e capelão papal pelo Papa Inocêncio IV. Vale ressaltar que a família Orsini exercia uma significativa influência na política a favor do papado contra 0 império. Por exemplo, seu pai Matteo Rosso Orsini era um senador importante de Roma em 1241.

\footnotetext{
${ }^{242}$ A atuação política, o generalato e a interpretação sobre a pobreza da Regra de Boaventura de Bagnoregio localizam-se no capítulo três desta dissertação.

${ }^{243}$ ALLEGREZZA, Franca. "Niccolò III". In: ENCICLOPEDIA dei Papi. Roma: Istituto della Enciclopedia italiana, 2000, 2v, p. 437.
} 
Já em 1255, Giovanni Gaetano, ou Giangaetano, obteve as suas primeiras tarefas eclesiásticas relevantes, como a execução de trabalhos sobre graves questões doutrinais e teológicas, examinou o Tractatus de periculis novissimorum temporum de Guilherme de Saint-Amour (1220-1272) e assumiu o processo contra o ex-ministro geral João de Parma da Ordem Franciscana, acusado de heresia. Também foi o cardeal mais indicado e com melhor desempenho na mediação política entre França e Inglaterra. Porém, foi somente no pontificado de Urbano IV (1261-1264) que a influência do cardeal Giangaetano cresceu, quando, em 1262, assumiu a posição de inquisitor generalis e de cardeal protetor da Ordem Franciscana ${ }^{244}$.

Giangaetano foi eleito papa no dia 25 de novembro de 1277 em Viterbo por oito cardeais e consagrado papa na capela de São Pedro no dia 26 de dezembro de $1277^{245}$. Logo após a eleição de Nicolau III, o ministro geral frei Buonagrazia visitou o novo papa em Soriano para com ele examinar as questões relativas à Ordem. Um dos problemas consistia na escolha de um novo cardeal protetor e na nomeação de uma comissão para elaborar oficialmente uma nova interpretação da Regra, devido aos ataques externos aos quais a Ordem se via exposta na questão da pobreza e também em relação ao relaxamento da prática da pobreza nos diversos conventos. Naquela ocasião o nome indicado foi do cardeal Mateus Orsini, sobrinho do papa.

Sendo assim, no dia 14 de agosto de 1279, o papa Nicolau III (12771280) promulgou a Decretal Exiit qui seminat, sob orientação jurídica, anulando todas as declarações precedentes sobre a Regra Franciscana, inclusive a Carta Quo Elongati. Esta bula foi promulgada com o intuito de anular as mitigações de Inocêncio IV que teria estendido demais as coisas utéis e cômodas, comprometendo a pobreza franciscana. Nicolau III também tinha sido protetor da Ordem e seguiu a tendência dos seus predecessores de ver a pobreza sob o ângulo jurídico; desta maneira, de uma forma reducionista apresentou uma renúncia total ao direito de propriedade aos frades e ao uso moderado das coisas (usus moderatus). No entanto, a novidade da Exiit estava focada na avaliação do que era necessário, que ficaria a critério dos superiores provinciais que adaptariam as necessidades moderadas de acordo com os

\footnotetext{
244 IDEM, Ibidem, pp. 437 e 438.

${ }^{245}$ BURGAUX. Ch, Histoire des Papes. Versaliis: Persan, 1949, p. 156.
} 
lugares e situações. Não seria mais possível estabelecer uma norma geral para toda a Ordem. Com esta medida, o papa Nicolau III descentralizou a questão da pobreza, dando maior autonomia de decisão aos ministros provinciais.

Sabemos que o Decreto Exiit qui seminat contou para a sua redação com a colaboração de material fornecido pela comissão formada pelo Cardeal franciscano Jerônimo de Ascoli (ex-ministro geral e futuro Papa Nicolau IV), pelo jovem provençal frei Pedro de João Olivi, frei cardeal Bentivenga dei Bentivenghi, dos ministros provinciais da França e da Irlanda e de Benedito Caetano (futuro Papa Bonifácio VIII). Além disso, as finalidades desta bula eram múltiplas, mas o principal objetivo seria dar cobertura à Ordem contra os diversos ataques externos e conflitos internos, e, mais uma vez, aclarar aos franciscanos os pontos duvidosos da Regra de 1223 que ainda não haviam sido resolvidos ${ }^{246}$.

Como já mencionamos, a nova constituição foi uma resposta aos frades e ao ministro geral Buonagrazia, que no Capítulo geral de Pentecostes de 1279 invocaram a intervenção do papa. De maneira apologética e jurídica, o papa anulou todas as declarações precedentes sobre a Regra e seguiu a tendência de ver a pobreza sob o ângulo jurídico numa série de artigos na qual introduzia uma passagem da Regula bullata e pronunciava um comentário sobre as passagens em dúvida de interpretação citadas, prática já adotada pelos seus antecessores ${ }^{247}$.

Para Nachman Falbel, o Decreto foi proposto ao novo ministro geral para estabelecer a harmonia entre os frades. Já para Grado Merlo a bula Exiit qui seminat revelou um projeto de Nicolau III que teve um alcance amplo e determinante, organizado por um discurso dividido em doze pontos, que seria algo mais amplo do que uma tentativa de harmonizar a Ordem. E Andrea Tabarroni afirma que a constituição interpretativa da Regra de Nicolau III segue a tendência da Quo elongati de Gregório IX com a diferença de que as suas respostas às dúvidas dos frades são mais difusas e detalhistas evidenciando a intenção de apresentar as decisões do pontífice como nascida de um esforço exegético no cotejamento da Regra. Trazendo inspiração do amplo material

${ }^{246}$ Esclarecer "os pontos duvidosos e obscuros" da norma virou um tópos - lugar-comum usado pelos papas como uma justificativa para a redação de uma nova constituição. Ver FALBEL, Nachman. Os Espirituais..., p. 109.

${ }^{247}$ Cf. MERLO, Grado. Op. cit., p. 157. 
apologético consultado das obras dos teóricos da Ordem, Nicolau III empenhou-se numa obstinada refutação das principais objeções dos adversários da Regra naquele momento. ${ }^{248}$

Por isso, a Carta de 1279 foi iniciada pelo papa com uma solene declaração do pleno valor evangélico da Regra, que teria sido confirmada pelo próprio Cristo, através das chagas no bem-aventurado Francisco. Mesmo após a confirmação de Cristo ainda existiriam os que atacavam os Frades menores e a Regra bulada de 1223, julgando-a "ilícita, inobservável e perigosa", desconsiderando os numerosos atos de aprovação e a confirmação dos pontífices predecessores, inclusive a declaração do II Concílio de Lyon de 1274, legitimada pelo papa Gregório X (1271-1276), sobre a "evidente utilidade" dos Menores para a Igreja universal.

\begin{abstract}
Hay gente que no quiere reconocer que esta santa Regla ha sido, como acabamos de decir, instituida por los preceptos y consejos del Salvador, fortificada por la doctrina y la vida de los apóstoles. Que ha sido aprobada por varios Soberanos Pontífices, confirmada por la Sede Apostólica, y dotada de muchos testimonios divinos, verdaderamente dignos de crédito. Dado que se ve brillar a tantos religiosos santos que han pasado su vida y terminado su días en la observancia de esta Regla. [...] En fin, como lo dijo recientemente, en estos mismos días, por así decirlo, nuestro predecesor de piadosa memoria, el Papa Gregorio X, aprobó dicha regla en razón de su manifiesta utilidad para la Iglesia universal. Esto fue declarado en el Concilio General de Lión ${ }^{249}$.
\end{abstract}

Deste modo, Nicolau III iniciou a sua intervenção para eliminar os "pontos duvidosos (dubia)" referentes à Regra proferidos em doze pontos, dando cumprimento a algumas declarações de seus predecessores (Gregório IX, Inocêncio IV e Gregório X) e provendo ulteriores precisões. Assim, o objetivo da Exiit qui seminat foi definido pelo papa.

Por lo cual nos ha parecido bien cerrarles el camino a los envidiosos que los muerden, y declarar las cosas que en la Regla pudieran parecer dudosas, y exponer con mayor claridad las que ya han sido declaradas por nuestros predecesores, a fin de satisfacer la

\footnotetext{
${ }^{248}$ TABARRONI, Andrea. Op. cit., p. 119.

${ }^{249} \mathrm{O}$ grifo é nosso. Não era apenas uma questão de negar a Regra de 1223, mas também de negar a importância da Ordem franciscana para a cristandade, os Concílios e decisões dos papas anteriores a Nicolau III. O texto da bula Exiit qui seminat de 1279 de Nicolau III aqui utilizado é uma tradução espanhola dos frades franciscanos del Sur, disponível em <http://www.franciscanos.net/document/exiit.htm> Acesso em: 20 agos. 2009.
} 
delicadeza de la conciencia de los Hermanos en relación a algunos puntos que tocan la Regla misma. ${ }^{250}$

Para reforçar a sua argumentação e justificar uma nova interpretação da Regra de 1223, o papa recordou a sua experiência com os franciscanos e a sua familiaridade específica revelada pelo seu passado como cardeal protetor da Ordem Franciscana nos anos de 1261 e 1262. No ano de 1263, foi cardeal protetor da Ordem das "Pobres Damas", movimento feminino franciscano. Por ter exercido o cargo de cardeal protetor da Ordem Franciscana, como ele mesmo afirmou com a função de proteger, governar e corrigir a Ordem dos Menores de acordo com a Regra bulada, Nicolau III argumentou conhecer a piedosa intentio do Santo fundador acerca das coisas que tocavam à Regra, afirmação um tanto questionável visto que Francisco faleceu em 1226 e o papa não o conheceu pessoalmente; contudo sabemos que isso configura mais um topos literário. Além disso, Nicolau III não tinha uma experiência tão vasta assim com a Ordem como ele afirmou.

\begin{abstract}
Además, desde nuestra más tierna infancia, hemos profesado nuestro afecto a esta orden. Habiendo crecido entre sus Hermanos, frecuentemente hemos conversado con ellos acerca de la Regla y de la santa intención del mismo Bienaventurado Francisco. Hemos tenido la oportunidad de tratar con algunos de sus compañeros, testigos de su vida y de sus conversaciones. Más adelante, una vez que vestimos la púrpura, habiendo recibido de la santa sede el oficio de protector, gobernador y corrector de la orden, hemos podido conocerla mejor aún. Dicho oficio me hizo en cierto sentido como palpar las condiciones de su existencia. Sentado ahora en el trono apostólico, estamos persuadidos, tanto por los medios citados, como por una larga experiencia propia, que es necesario precisar cuál fue la piadosa intención del santo fundador acerca de cosas que tocan la Regla misma, y a su observancia. ${ }^{251}$
\end{abstract}

Mas, o objetivo principal da Exiit foi sem dúvida a declaração com o selo da autoridade pontifícia de que a Regra foi inspirada diretamente de Deus para Francisco e então configurada conforme o modelo evangélico. Por isso era meritória, santa e observável para os frades que faziam parte da cristandade. Nesta declaração, pronunciada com toda solenidade possível, vieram a confluir as três distintas fontes de autenticação da Regra: o carisma de Francisco de Assis, a conformidade com o Evangelho e a definição

\footnotetext{
${ }^{250}$ IDEM, ibidem.

${ }^{251}$ Disponível em <http://www.franciscanos.net/document/exiit.htm> Acesso em: 20 agos. 2009.
} 
magistral da Igreja. E propõe uma nova interpretação legislativa que, segundo Nicolau III, seria perfeita e resolveria todos os pontos duvidosos da Regra apostólica por ser a interpretação mais completa, precisa e por conter uma explicação jurídica mais profunda do que a dos predecessores: "Queremos terminar con esta carencia y oscuridad proponiendo una interpretación perfecta, y a fin de librar a los espíritus de toda duda y escrúpulo haremos una

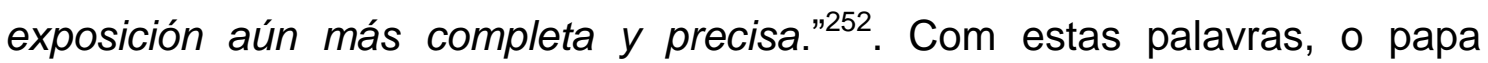
Nicolau III deixou claro que a sua interpretação seria a mais completa em relação aos seus predecessores e ameaçou de excomunhão a quem ousasse interpretar, expor ou, sobretudo, comentar as disposições contidas na sua declaração. Na verdade, a interpretação dele seria mais completa pelo simples fato de neste período o debate jurídico ter-se desenvolvido de maneira mais eficiente, além da Ordem contar com uma produção extensa de Expositiones.

Como bem observa Edith Pásztor, no discurso da Exiit é possível perceber, com muita precisão, as características da Ordem franciscana no tempo do pontificado de Nicolau III, a saber, o alto nível cultural atingido pelos frades graças aos seus vínculos com o mundo universitário; a clericalização com a presença também no topo do alto clero (diocese); a consolidação da estrutura hierárquica. ${ }^{253}$. E o mais importante ressaltado pela autora foi a dificuldade de inserção dos frades laicos, não cultos, desejosos de observar a pobreza na simplicidade, se os compararmos aos demais frades clérigos de formação; era uma difícil convivência que Nicolau III prenúncia na Exiit. Sabemos que o movimento Franciscano é laico na sua origem, a presença leiga sempre foi complicada desde o princípio devido à rápida clericalização do movimento, ainda mais porque o próprio fundador e modelo a ser seguido por toda a Ordem era laico, e também porque a instituição estava bem distante da primeira geração deste movimento.

No primeiro artigo, um ponto a se destacar foi a recomendação principal da Regra de 1223, o observar o Santo Evangelho. O papa dispôs sutilmente que os Menores deveriam observar tanto os conselhos quanto os preceitos que na Regra são mencionados, fossem "de forma preceptiva ou proibitiva, ou então com expressões equivalentes".

\footnotetext{
252 IDEM, ibidem.

${ }^{253}$ PÁSZTOR, Edith. Op. cit., p. 340.
} 
Aparece manifiesto por el contexto de la Regla que tal sea el sentido de San Francisco en las palabras citadas. En ella algunos consejos evangélicos son presentados como consejos, bajo palabras de admonición, exhortación o consejo. Otros son formulado con forma de prohibición o con palabras de precepto. Lo cual muestra claramente que la intención del legislador no ha sido la de obligar a los Hermanos por la profesión de la Regla a la observancia tanto de todos los consejos como de todos los preceptos del evangelio. Sino solamente de aquellos que en la misma Regla están formulados bajo forma de precepto o de prohibición, o con palabras equivalentes. ${ }^{254}$

Já no segundo artigo da Exiit qui seminat o papa tratou do tema básico e central da Regra de 1223: a pobreza, a mendicância e a renúncia a toda a propriedade e domínio.

Nadie se atreva a contradecirnos equivocadamente afirmando que quiénes renuncian de tal modo a la propiedad son suicidas, y que tientan a Dios, poniendo su vida en peligro. Sin duda que no. Porque para vivir se confian en la divina Providencia sin desdeñar ninguna providencia humana. Al contrario, están sostenidos: o bien por las ofrendas espontáneas 0 bien por lo que ellos mendigan humildemente; o por lo que ellos consiguen por su propio trabajo. Tal es la triple vía que la Regla expresamente preve como modo de vida. ${ }^{255}$

Segundo Grado Merlo, esse ponto recebeu uma resolução totalmente em defesa do absoluto caráter evangélico da "renúncia à propriedade de tudo, tanto pessoalmente como em comum", pois, como justifica Nicolau III, ela é "meritória e santa", tendo sido ensinada com a palavra e com o exemplo do próprio Cristo e seguida pelos apóstolos ${ }^{256}$.

A fin de que los discursos de estos ignorantes no lleguen a obscurecer la claridad de la perfecta profesión de los mismos Hermanos, decimos que la renuncia a la propiedad de todas las cosas por Dios, tanto en privado como en común, es santa y meritoria. Ha sido propuesta por Cristo, quien, para mostrarnos el camino, ha enseñado la perfección con sus palabras y la ha confirmado con sus ejemplos. ${ }^{257}$

Merlo faz questão de indagar se a argumentação de Nicolau III sobre a renúncia a toda a forma de propriedade significava confiar-se à Providência divina sem renunciar ao uso das coisas indispensáveis à vida humana, que os

\footnotetext{
${ }^{254}$ Disponível em <http://www.franciscanos.net/document/exiit.htm> Acesso em: 20 agos. 2009. ${ }^{255}$ IDEM, ibidem.

${ }^{256}$ Ver MERLO, Grado. Op. cit., p. 158.

${ }^{257} \mathrm{O}$ grifo é nosso para enfatizar os termos empregados. Exiit... IDEM, ibidem.
} 
frades buscavam, segundo a Regra, através de generosas doações, da humilde mendicância e do "laboritium", palavra usada no Testamento por Frei Francisco e trazida na Exiit qui seminat literalmente. Nesse caso, depreendemos que a Decretal reafirmava a renúncia à propriedade, e, ao estabelecer uma diferença entre a sua posse e o seu uso, o papa Nicolau III trazia uma série de sutilezas jurídicas enriquecendo o debate da pobreza da Regra.

\begin{abstract}
La renuncia a todo tipo de propiedad de ninguna manera debe entenderse como obligación a la renuncia del uso de las cosas. Porque en los bienes temporales es importante distinguir la propiedad, la posesión, el usufructo, el derecho al uso, el simple uso de hecho. De este último, el simple uso de hecho, todos tenemos necesidad por ser necesario para mantenernos en vida, aunque carezcamos de todos los anteriores. Y no hay profesión alguna imaginable que pueda excluir el simple uso de hecho. A quiénes hicieron voluntariamente profesión de seguir a Cristo pobre, en la observancia de una tan gran pobreza, les conviene renunciar a todo dominio y contentarse con el uso necesario de las cosas. ${ }^{258}$
\end{abstract}

Sendo assim, os frades poderiam ter o "usus facti" ou uso de fato de todas as coisas que lhes seriam necessárias para a vida como a alimentação, o vestuário, o acesso ao culto divino e ao estudo sapiencial, mas deveriam usálas de modo moderado (usus moderatus), limitado à necessidade, para que

${ }^{258}$ Exiit qui seminat.... Os grifos são nossos para reforçar os termos empregados. Os principais aspectos da pobreza jurídica levantados por Boaventura na obra Apologia pauperum contra calumniatorem foram usados por Nicolau III na Exiit, a saber, são eles: renúncia a todas as formas de domínio, diferenciando o usus e a proprietas, a possessão, o usufructo, o simples uso, a prática da esmola e a renúncia ao dinheiro. No texto de Nicolau III, todos esses conceitos aparecem de forma aprofundada e mais precisa, mas fica evidente que foi uma "releitura" dos conceitos desenvolvidos por Boaventura. Ao levantar a questão da pobreza de Cristo e dos Apostólos, mostrando a vida de perfeição evangélica, Boaventura, propõe uma definição peculiar da pobreza que passa pela renúncia aos direitos de propriedade que vem da Regra de 1223. No entanto, o seu conceito de renúncia aos direitos de propriedade perpassa pelo viés do direito civil, considerando a ausência de propriedade, a diferenciação entre 0 dominium e a proprietas. Segundo Boaventura: "Pero como acerca de la posesión de las cosas temporales pueden considerarse dos cosas, a saber, el dominio y el uso, y el uso está necesariamente ligado com la presente vida, es próprio de la pobreza evangélica dejar las posesiones terrenas em cuanto al dominio y propiedad, y respecto del uso, no rechazarlo por completo, sino estrecharlo, según aquello que dice el Apóstol a Timoteo: Teniendo alimentos y com qué cubrirnos, con estas cosas estamos contentos. [...] una, por la cual alguno, renunciando el dominio particular o personal de todas las cosas temporales, se sustenta de lo que no es suyo, es decir, de lo que no le es proprio, sino participando con otros y simultáneamente poseído com derecho común; otra, por la cual alguno, renunciando todo dominio de las cosas, lo mismo en particular que em común, se sustenta de lo no suyo, es decir, de lo no proprio, sino ajeno, ofrecido, sin embargo, piadosa y justamente por otros para su sustento."

Apud SÃO BOAVENTURA. Apologia pauperum contra calumniatorem. In: Obras de San Buenaventura. Edicion bilingue. Madrid: Pontificia Universidad de Salamanca, La Editorial Catolica,1949, p. 493. 
"neles e em suas ações" sempre resplandecesse a Santa Pobreza. Por isso, o "uso simples" necessário não o era de direito, era somente permitido aos frades pela Regra como sendo o "uso moderado" das coisas necessárias à vida ${ }^{259}$.

La misma Regla quiere, en fin, que 'en la predicación que hacen los Hermanos, sus palabras sean examinadas y castas, para utilidad y edificación del pueblo, anunciándoles los vicios y las virtudes, la pena y la gloria'. Pero es evidente que esto supone la ciencia, y la ciencia exige el estudio, y el ejercicio del estudio no puede hacerse convenientemente sin el uso de los libros. De lo cual resulta suficientemente claro que la Regla concede a los Hermanos el uso de las cosas necesarias para el alimento, el vestido, el culto divino y el estudio de la sabiduría. 260

O papa ordenou que competia à livre escolha dos ministros e custódios precisar de que consistiria na concretude da vida diária o "uso de fato", para que provessem segundo o que pedem "a qualidade das pessoas, a diversidade dos tempos, as condições locais e outras circunstâncias particulares". Para garantir estas afirmações e orientações, Nicolau III confirmava o domínio eclesiástico sobre os bens concedidos aos frades, segundo o já estabelecido por Inocêncio IV e Gregório IX. Desta maneira, a Igreja assumia a propriedade e o domínio de todos os bens dos Menores, excetuando apenas os bens cuja

\footnotetext{
${ }^{259}$ MERLO, Grado G. Op. cit., p. 158.

260 Exiit... IDEM, Ibidem. A obra Apologia pauperum contra calumniatorem foi composta em defesa da pobreza franciscana num momento de disputas entre os cleros seculares e regulares, o escrito representava a tradição ortodoxa franciscana, sem deixar de contemplar, em certa medida, as aspirações daqueles que pretendiam defender a pobreza radical. Respeitado pelos seguidores de Frei Leão e Elias, Boaventura de Bagnoregio foi um personagem que sintetizou a atitude e o ideal Franciscanos de maneira completa. Ele teria escrito esse opúsculo sendo já ministro geral e, provavelmente, antes de 1269. A ocasião era, portanto, aquela da defesa das ordens Mendicantes contra as acusações lançadas pelos mestres de Paris. Boaventura dividiu sua obra em doze capítulos, que se fazem acompanhar de um breve prólogo, no qual ele expõe a obrigação de amar e buscar a verdade no que concerne à fé e aos costumes, fazendo um obséquio de nossa inteligência à Suma Verdade, bem como a obrigação de evitar e reprimir todos os erros, assim como trabalhar por aqueles que erram. O "caluniador" em questão era Geraldo de Abbéville em especial - que escrevera em defesa de seu amigo Guilherme de Saint-Amour - , além dos mestres de Paris que se haviam insurgido com acusações aos Mendicantes. $O$ trecho mais importante sobre o conceito de pobreza em Boaventura está no capítulo XI da Apologia, quando Boaventura expôs os quatro termos do direito civil em relação à pobreza franciscana que "Así, pues, para que sea impuesto silencio a estas y semejantes cavilaciones malignas y dolosas, se ha de entender que acerca de las cosas temporales deben considerarse cuatro cosas, a saber, la propiedad, la posesión, el usufructo y el simple uso; que de las tres primeras puede carecer la vida de los mortales, y que, necesitando la última como de algo indispensable, en modo alguno puede existir profesión que abdique totalmente el uso de las cosas temporales". Apud SÃO BOAVENTURA. Apologia..., p. 643.

Sobre a disputa entre os mestres seculares, ver o artigo: MARANESI, Pietro. "I commenti alla Regola francescana e la questione dello studio". In: Studio e Studia: Le scuole degli ordini mendicanti tra XIII e XIV secolo. Atti del XXIX Convegno internazionale. Assisi, 11-13 ottobre 2001. Espoleto: Centro italiano di studi sull'Alto medioevo, 2002, pp. 33-81.
} 
propriedade o doador reservasse para si ou para seus herdeiros. Na verdade, Nicolau III reforçou o que o seu antecessor havia decidido na Ordinem vestrum.

\begin{abstract}
Ahora bien, en lugar de Dios no hay nadie a quien el dominio de tal bien pueda ser transferido de modo más conveniente que la persona del Romano Pontífice, Vicario de Cristo, y la Sede Apostólica. EI Papa es, en efecto, el Padre de todos, y especialmente de los Hermanos Menores. El Hijo adquiere para su Padre los bienes que le son ofrecidos, concedidos o donados. De modo semejante a que el servidor los recibe para su señor, el monje para su monasterio. Por tal motivo, a fin de no dejar incierto el dominio de los bienes donados a los Hermanos, reiteramos nosotros mismos lo que ya fue hecho por nuestro predecesor Inocencio IV, de feliz memoria. Recibimos por autoridad apostólica para nosotros mismos y para la Iglesia Romana, el dominio y la propiedad de todos los utensilios, libros y muebles, presentes y futuros, que la Orden y los mismos hermanos puedan obtener lícitamente, y de los cuales pueden usar, con simple uso de hecho. ${ }^{261}$
\end{abstract}

Desta forma, a pobreza franciscana encontrou um maior respaldo e garantia com a declaração papal de reservar a si e aos seus sucessores todos os bens dos frade; tanto os bens móveis quanto os imóveis passariam a ser propriedade particular da Cúria Romana. Ademais, a pobreza estava ainda mais garantida quando a Decretal recordava o "usus pauper" (uso pobre), das "coisas necessárias", evitando-se a "superfluidad, abundancia, riqueza o con una acumulación que destruya la pobreza, aquellos bienes que les están permitidos."262.

${ }^{261}$ Exiit... IDEM, Ibidem. Concordamos com Malcolm Lambert em relação à influência de Boaventura na Exiit: "Tuttavia, la discussione giuridica di Bonaventura non è stata riportata nella bolla integralmente e senza variazioni, come invece accade per la discussione teológica: si registrano omissioni e modifiche. I termini utilizzati da Bonaventura sono stati cambiati. In un parágrafo della Apologia, nel quale egli si era soffermato più precisamente sulla terminologia del diritto civile, aveva proposto um elenco di quattro termini giuridici rilevanti: proprietas, possessio, ususfructus, simplex usus. La Exii qui seminat, pur riprendendo la sostanza dell'argomentazione di Bonaventura, modifica i termini, presumibilmente per garantire maggiore precisione. Cinque sono ora i termini da considerare: proprietas, possessio, ususfructus, ius utendi e simplex usus facti.". Cf. LAMBERT, Malcolm D. Povertà Francescana. La dottrina dell'assoluta povertà di Cristo e degli Apostoli nell'Ordine Francescano (1210-1323). Milano: Edizioni Biblioteca Francescana, 1995, p.140.

Enfim, a releitura da obra Apologia aos pobres de Boaventura pela comissão papal e por Nicolau III foi fundamental para compreendermos a retórica interna da Constituição da Exiit qui seminat, porque consistiu num texto base para a construção da argumentação jurídica, baseada no direito civil sobre a pobreza franciscana. Indubitavelmente, em 1279, o legado de Boaventura foi essencial e indispensável para toda a Ordem e referência para o papa em exercício. Por isso, ao analisar as sutilezas jurídicas da Exiit de Nicolau III não podemos perder de vista os principais aspectos da Apologia de Boaventura porque é uma referência muito direta.

${ }^{262}$ Disponível em <http://www.franciscanos.net/document/exiit.htm> Acesso em: 20 agos. 2009. 
Tanto que dichas necesidades sean inmediatas o inminentes y de pronta solución en el tiempo, como que, menos frecuentemente, conlleven necesariamente más tiempo, como la edición de libros, la construcción de iglesias o residencias, compra de tejidos o de libros en lugares remotos, $u$ otras cosas semejantes que se puedan presentar, necesidades todas que tienen que ser saludablemente prevista con la moderación arriba mentada. [...] En cuanto a los libros y a los muebles de la Orden que no son propiedad de nadie en particular, por ese mismo hecho pasan a ser propiedad particular de la Iglesia Romana, inclusive para el caso de su venderlos o cambiarlos. ${ }^{263}$

Outro ponto a se destacar no tocante à pobreza era o número de hábitos, que foi resolvido da seguinte forma. Enquanto a Regra de 1223 definia que os frades só deveriam ter duas túnicas, uma com capuz e outra sem capuz, Nicolau III instituía que os frades poderiam ter várias túnicas com a permissão dos ministros e custódios, e, mesmo assim, estariam de acordo com a Regra, visto que quando esta havia sido formulada as circunstâncias eram bem diferentes, não havia tantos frades e nem províncias tão longínquas. Mais uma vez o papa usava uma argumentação bastante flexível para a resolução deste impasse.

Si bien en la Regla se dice: "que los Hermanos tengan una túnica con capucho y otra sin capucho". Y si bien la intención del fundador parece no conceder sin necesidad el uso de varias túnicas, sin embargo, declaramos que con el permiso de los Ministros y de los Custodios, tanto en conjunto, como separados en sus respectivas administraciones, los Hermanos podrán usar varias túnicas, según los Ministros y Custodios consideren bueno, teniendo en cuenta las necesidades diversas y otras circunstancias a pesar atentamente según Dios y según la Regla. Obtenido este permiso, los Hermanos no deben en modo alguno pensar que se han desviado de la Regla. [...] Sin embargo, hay que considerar atentamente que en el tiempo en que la Regla ha sido redactada, cuando los Hermanos no eran tan numerosos como al presente, pudieran haber parecido suficientes Ministros y Custodios para tales cuidados. Hay que observar, considerando tanto la multiplicación de los Hermanos como la condición de los tiempos presentes, si el Bienaventurado Francisco, institutor de la Regla habría querido imponer a los Ministros y Custodios un yugo tan pesado, imposible de llevar. O si habrá querido, en consecuencia de esta imposibilidad, privar a los Hermanos de bienes indispensables. ${ }^{264}$

Outro aspecto importante concentra-se no artigo sobre a pregação, onde o papa estabeleceu uma diferença no empenho da "cura das almas" como um "trabalho espiritual" de maior valor que o trabalho manual. Para os

\footnotetext{
${ }^{263}$ IDEM, ibidem.

264 IDEM, Ibidem.
} 
Menores, a pregação era impriscindível; a Regra de 1223 é muito clara neste aspecto e, na verdade, Nicolau III estava seguindo a decisão tomada por Gregório IX na Quo Elongati de 1230, não trazia nada de novo, apenas explicava pormenorizadamente.

Según el ejemplo de Cristo y de un gran número de Santos Padres, este trabajo espiritual supera al trabajo manual tanto como las cosas del alma están sobre las cosas corporales. Declaramos, pues, que las mencionadas palabras de la Regla se aplican a los Hermanos que no están encargados de los oficios espirituales, y que serían ociosos si no se ocuparan convenientemente en el servicio de los demás. ${ }^{265}$

Em outro artigo, Nicolau III estendeu a autorização de pregação aos ministros provinciais, argumentando que o número de frades havia crescido numericamente e o ministro geral não conseguiria dar conta da demanda. Assim, o papa dava uma nova solução jurídica ao afirmar a possibilidade de os ministros provinciais e custódios auxiliarem na administração dos negócios da Ordem, o ministro geral, principalmente, no envio de frades à pregação ou às missões, que não teriam condições práticas de ficar a cargo de uma única pessoa.

\begin{abstract}
En este mismo capitulo la Regla añade inmediatamente: "que ninguno de los Hermanos tenga la osadía de predicar al pueblo si no después de haber sido examinado y aprobado por el Ministro General, y de haber obtenido de él el oficio de la predicación". Hay que tener en cuenta el estado original de la Orden, cuando tenia pocos miembros, y ver ahora en la actualidad tan gran número de Hermanos, y considerar la utilidad de las almas. ${ }^{266}$
\end{abstract}

Não se pode admitir qualquer pessoa na Ordem, segundo o papa, sem ver o quanto seria "útil" para a Ordem, se se fazia fnecessário um exame prévio do candidato, e neste ponto não destoando totalmente da Regra, que também estabelecia uma admissão ou recepção de novos membros com cautela e exame dos sacramentos. No entanto, o papa introduziu um rigor maior do que aquele estipulado pela Regra através de um critério não muito claro sobre quem seria "útil" para a Ordem.

No se deben admitir en la Orden a todos indiferentemente. Solo han de ser admitidos quiénes puedan ser útiles a la Orden por su instrucción, aptitudes u otras condiciones requeridas, y a quiénes

\footnotetext{
${ }^{265}$ Disponível em <http://www.franciscanos.net/document/exiit.htm> Acesso em: 20 agos. 2009. ${ }^{266}$ IDEM, Ibidem.
} 
sean capaces de adquirir méritos para si mismos y dar buen ejemplo a los demás. ${ }^{267}$

Um ponto que causava dúvidas era em relação ao número de custódios para a eleição do ministro geral, pois a Regra indicava que todos deveriam participar, mas, devido ao número grande de membros, o papa definia que deveria haver uma seleção prévia dos que seriam enviados. "Respondemos que los Custodios de cada Provincia deben escoger uno de entre ellos, para confiarle su voz y sus funciones, enviándoles al Capítulo General en lugar suyo, junto al Ministro Provincial."268

A proibição de os Menores ingressarem nos mosteiros femininos segue a bula Quo Elongati de Gregório IX de 1230. Não houve nada de novo sobre este aspecto, só o citamos aqui para ressaltar que a Carta de Gregório IX era um ponto de referência, ora para retomar o assunto e melhor desenvolvê-lo, ora para reafirmar algo já definido e que não havia necessidade de mudança.

Respondemos que, en general, esta prohibición se extiende a todos los Monasterios de Monjas. Y por Monasterios queremos que se entienda el claustro, las habitaciones, las oficinas interiores. Los Hermanos pueden entrar a los lugares que son visitados por los seglares. Tanto para pedir limosna como para la predicación, al menos aquellos que los Superiores han autorizado, viendo su madurez y aptitudes. ${ }^{269}$

Nicolau III reafirma que o Testamento de 1226 não teria o mesmo estatuto jurídico que a Regra, ou seja, não se the deveria atribuir um valor legislativo. Por isso, os Menores não eram obrigados a observá-lo, somente a Regra de 1223 teria o valor de norma que todos deveriam seguir. Mais uma vez, Nicolau III não trouxe nada de novo, foi o papa Gregório IX o precursor da negação do valor legislativo do Testamento em 1230; como ele mesmo mencionou, não pretendia inovar nada quanto ao assunto, apenas reafirmar porque havia o questionamento sobre isso na Ordem.

Por lo cual los Hermanos se preguntan con mucha hesitación si están obligados a observar este Testamento. Ya propusieron sus dudas a nuestro predecesor, Gregorio IX, rogándole clarificara sus conciencias. Se dice que este Pontífice, considerando los peligros de las almas, y las dificultades que Podrían encontrar en dicho punto, quitar las dudas de sus corazones, diciendo que los Hermanos no

\footnotetext{
267 IDEM, Ibidem.

268 IDEM, Ibidem.

269 IDEM, Ibidem.
} 
están obligados a observar este Testamento, que no podría obligar sin su consentimiento, y más aún con el de los Ministros, puesto que a todos concernía. Y que San Francisco no podría tampoco obligar a su sucesor, no teniendo nadie autoridad sobre sus pares. Creemos conveniente no innovar nada en este punto. ${ }^{270}$

Ao finalizar, Nicolau III determinou que o decreto Exiit qui seminat fosse definido como uma "constitutio", por isso deveria ser lido nas escolas, mas de nenhum modo poderia ser objeto de discussões ou de comentários escolares; ao contrário, deveria ser esclarecida "fielmente ao pé da letra" e da "forma mais compreensível”271.

Si bien se confirman en todo o en parte las otras Letras Apostólicas mencionadas, los hermanos no tendrán que observar ninguna otra constitución que la nuestra. Y esta Constitución, declaración y ordenación, debe ser observada inviolablemente a perpetuidad. [...] Es evidente que la Regla es licita y santa y perfecta y observable, y que no expone a ningún peligro. ${ }^{272}$

Para concluir a Exiit qui seminat, Nicolau III encerrou afirmando que a Regra de 1223 deveria ser entendida de acordo com os artigos do Decreto exposto por ele, sem glosa, e ainda ameaçava com a excomunhão aqueles que ousassem escrever ou falar contra a Regra, os Frades menores e a sua profissão.

\begin{abstract}
Mandamos rigurosamente que la presente Constitución sea expuesta fielmente y a la letra, tal como ha sido promulgada. $Y$ que los Lectores o Expositores no añadan ninguna concordancia, ni objeción alguna, ni cualesquiera opiniones, divergentes u opuestas. Que de ningún modo se hagan glosas sobre esta Constitución, a no ser para explicar la letra, casi gramaticalmente, a fin de hacerla más inteligible. [...] A nadie le estará absolutamente permitido infringir esta Declaración, ordenación, concesión, disposición, adición suplementaria, aprobación, confirmación y constitución. Nadie podrá contravenirla con temeraria audacia. ${ }^{273}$
\end{abstract}

Como vimos, o problema central da Exiit foi novamente a concepção (antes mesmo que a prática) da pobreza, que é o elemento característico e discriminante da identidade franciscana, com consequências sobre a vida dos

\footnotetext{
${ }^{270}$ IDEM, Ibidem.

${ }^{271}$ MERLO, Grado. Op. cit., p. 158.

272 Disponível em <http://www.franciscanos.net/document/exiit.htm> Acesso em: 20 agos. 2009.

${ }^{273}$ Exiit..., IDEM, Ibidem.
} 
Menores e com incidências potencialmente explosivas no plano eclesiológico e no âmbito eclesiástico como nos aponta Merlo ${ }^{274}$.

A pobreza é um conceito fundamental para se entender a Regra de 1223 e o Testamento de São Francisco, contudo, conforme o momento histórico da Ordem, dependendo do pontífice e da sua exegese acerca da Regra, a ideia de pobreza se torna maleável e metamorfoseada. Apesar da pobreza franciscana se apresentar como uma pobreza voluntária representando a renúncia à posse, seguindo a direção das disposições jurídicas anteriores dos papas Gregório IX e Inocêncio IV, Nicolau III, ao promulgar a Exiit qui seminat, incluiu novas interpretações acerca dos "pontos duvidosos" da Regra.

No caso da Exiit qui seminat, o conceito de pobreza franciscana foi definido formalmente como uma renúncia total ao direito de propriedade e, concretamente, como um "uso moderado" das coisas necessárias à vida. Além disso, o conceito de "usus facti" (uso de fato) foi amplamente utilizado e não está muito distante do conceito de "usus pauper" (uso pobre) criado por Pedro de João Olivi ${ }^{275}$, um dos principais inspiradores dos "Espirituais" franciscanos. Em suma, ser "pobre" incluía o esforço do "uso pobre" dos bens; a partir dessa concepção o papa Nicolau III tentou adaptar a pobreza franciscana à realidade do seu pontificado, no qual a paupertas estava sendo mais pensada (discutida no plano jurídico) do que vivida (plano ascético).

$\mathrm{Na}$ verdade, ele tinha por objetivo restringir o uso das coisas que o papa Inocêncio IV havia estendido com o conceito de "coisas úteis e cômodas" na bula Ordinem vestrum de 1245. Ademais, a Ordem havia se tornado por demais liberal causando tensões entre os grupos que defendiam a pobreza de forma mais rigorosa. A tentativa de Nicolau III era de pacificar os ânimos e difundir harmonia. O papa pretendia colocar um ponto final nas querelas dos Menores e resolver a contradição da pobreza evangélica proclamada e a realidade cotidiana, e, sobretudo, dar uma cobertura precisa sobre as relações internas disciplinares da Ordem Franciscana.

\footnotetext{
${ }^{274}$ MERLO, Grado G. Op. cit., p. 159.

${ }^{275}$ Ver o capítulo três desta dissertação sobre a discussão em torno do conceito de pobreza de Pedro de João Olivi, o usus pauper.
} 
Como vimos, Nicolau III interveio na Regra com a sua interpretação de pontífice "in minoribus constitutus", recordando o cargo de cardeal protetor da Ordem, numa análise rica e bem articulada da vida e dos problemas do franciscanismo. Ele expôs oito questões ${ }^{276}$ : a respeito da Quo elongati, o problema da jurisdição dos provinciais sobre os pecados públicos; em relação à Ordinem vestrum, omitiu a parte dos problemas relativos ao ofício divino e a cura dos ministros em propósito da necessidade dos frades, enquanto retomou e reafirmou a suspensão do Testamento. O pontífice empenhou-se sobretudo em se aprofundar nas funções declaradamente apologéticas, a primeira das três questões (obrigatoriedade dos conselhos evangélicos, estatuto jurídico da expropriação e as relações ao dinheiro): a isso tudo dedicou três quartos da constituição conforme vimos. Ao invés de permanecer nas cinco questões, Nicolau III repreendeu veementemente as decisões de Inocêncio IV que diziam respeito aos problemas da concessão do ofício da pregação e da competência em matéria de admissão na Ordem, enquanto retomou Gregório IX, embora se ativesse à aplicação da proibição de ingresso nos conventos femininos e o valor jurídico do Testamento; sobre a composição do Capítulo geral, enfim, repetiu a fórmula já usada por Gregório IX e Inocêncio IV. A narratio de Nicolau III teve a intenção de demonstrar a sua própria familiaridade com a vida e com os problemas da Ordem e o caráter excepcional do seu discurso, que constituiu uma incondicional exaltação da religio dos Menores. Além disso, a intervenção do papa ao propor um fechamento definitivo de autoridade no debate sobre 0 estatuto jurídico e salvífico da Regra franciscana, provocando os adversários da Ordem, ameaçando com excomunhão quem ousasse comentar a Exiit ou a Regra Franciscana, como o próprio Francisco havia comentado no seu Testamento que todos por obediência não poderiam acrescentar glosas ou comentários a estas palavras, parece que essa recomendação era impossível de ser adotada pelos frades na época anterior e posterior ao pontificado de Nicolau III. Perdeu-se a intangibilidade da Regra de 1223 naquele momento ${ }^{277}$.

\footnotetext{
${ }^{276}$ A respeito disso, ver o rodapé 67 em: TABARRONI, Andrea. Op. cit., pp. 119-120.

277 A intangibilidade da Regra foi um assunto bem desenvolvido por Angelo Clareno na sua Expositio, para ele, se a Regra foi ditada diretamente de Cristo a Francisco, numa alusão a Moisés e as tábuas da lei, portanto ninguém poderia ficar interpretando ou fazendo glosas a respeito da norma, já que a norma era semelhante ao Evangelho. Como escreveu Boaventura em uma de suas vitae, a Regra representava a reunião das migalhas do Evangelho, portanto a Regra representava a hóstia.
} 
O problema central perpassava sempre pela tensão dialética permanente entre a Regra codificada e a vida prática nos conventos, a aplicabilidade da "lex fundamentalis".

Por fim, a bula Exiit qui seminat de Nicolau III teve um efeito de resolver os problemas externos de ataque à Ordem dos Frades menores. Contudo, não resolveu os problemas internos da Ordem como pretendia o pontífice; nem todos os frades aceitaram esta nova interpretação acerca da Regra de 1223. Entre outros motivos, o afrouxamento do ideal de pobreza prática prosseguia e isto propiciou o surgimento dos "Espirituais" franciscanos logo em seguida.

Enfim, a pobreza consistia num litígio de difícil solução tanto em nível de reflexão teórica como no plano dos comportamentos e das opções concretas. O decreto Exiit qui seminat não resolveu a questão da pobreza que se prolongou em novas discussões e contendas no interior da Ordem dos Menores. Afinal, quando um papa comentava a Regra de 1223, geralmente para dar maior veracidade à sua exegese, argumentavam que conheciam a verdadeira intentio de Francisco, um lugar-comum para justificar a nova redação. Assim como seus predecessores, Nicolau III também conhecia a verdadeira intenção de Francisco, por isso a sua exegese acerca da pobreza seria a mais perfeita e completa. Na verdade, a exegese de Nicolau III soube melhor definir a Regra pela abundância de materiais consultados e porque a discussão já estava num plano bastante avançado. O pontífice atingiu a tradição apologética franciscana, ordernando, especificando e selecionando os trechos normativos para "reinterpretá-los". A identidade estava num confronto que o conhecimento do papel dos franciscanos não havia constituido num patrimônio bem definido, mas estava penosamente aprendida no tempo. Enfim, a autoridade papal, cuja Ordem era mais voltada ao passado, como num jogo de espelhos, propunha aos franciscanos como identidade à sua missão a imagem construida através de muitas crises. A despeito das intenções, das esperanças, e, certo também, dos temores dos contemporâneos, a questão estava antes de tudo fechada. Mais uma etapa de um longo processo, poderse-ia dizer, estava conclusa. ${ }^{278}$

${ }^{278}$ LAMBERTINI, Roberto. "Momenti della formazione dell'identità francescana nel contesto della disputa con i secolari (1255-1279)". In: Dalla "sequela Christi" di Francesco d'Assisi 
Conforme Merlo, a Exiit fez brotar uma situação paradoxal; a pobreza era uma condição básica para se atingir a perfeição evangélica pela renúncia ao domínio, por isso a discussão da aplicabilidade da Regra foi tão importante para toda a Ordem. Por um lado, eram desvalorizados os fundamentos de proprietas e iurisdictio, da organização da Igreja "neste mundo" e, por outro lado, ela era apenas graças ao poder jurisdicional da própria Igreja, assim, graças à "plenitudo potestatis" do papa que, reconhecendo a "abdicatio dominil" aos Menores, concedia uma dispensa das normas do direito civil que regulavam em sentido totalmente diverso o relacionamento dos indivíduos com as coisas ${ }^{279}$.

Por fim, a condição indispensável para se atingir a perfeição evangélica segundo as novas diretrizes era a pobreza, talvez para evidenciar a autenticidade da Regra franciscana, cada vez mais a Ordem dependia de uma sanção externa; mais adiante veremos que com João XXII decidiu-se retirar a validade da Exiit, a fonte de autenticação da Regra e o problema de autenticidade se colocará novamente numa forma dramática da "difícil herança" de Francisco, abrindo-se para uma nova dilaceração na Ordem dos Menores, que novamente gravitara no impasse entre a Regra (o projeto codificado da pobreza) e a vida dos frades (a aplicabilidade da codificação).

\subsection{Novos impasses jurídicos da Norma sob o pontificado de Clemente $V$ (1305-1314) e a Decretal Exivi de paradiso de 1312}

Clemente V ou Bertrand de Got era de origem nobre de uma família não abastada. Foi o primeiro papa de Avignon. Pertenceu à Ordem de Grandmont e estudou direito canônico e civil na Universidade de Orléans e Bolonha, obtendo o título de "magister", ou seja, possuia um conhecimento bastante razoável sobre o direito canônico da Igreja. Antes de mais nada, a sua boa formação jurídica foi essencial para a redação da próxima constituição papal, a bula Exivi de paradiso, que tinha por fim, assim como as predecessoras, esclarecer as "dubia (pontos duvidosos)" da Regra

all'apologia della povertà. Atti del XVIII Convegno Internazionale. Assisi, 18-20 ottobre 1990. Espoleto: Centro italiano di studi sull'alto medioevo, 1992, p. 172.

${ }^{279}$ Cf. MERLO, Grado. Op. cit., p. 179. 
Franciscana de 1223 e resolver as tensões internas da Ordem dos Frades menores em relação à pobreza.

Segundo a Enciclopedia dei Papi ${ }^{280}$, Bertrand de Got ainda muito jovem foi titular de um canonicato na catedral de Bordeaux e no colégio de Saint Caprais de Agen. Durante o pontificado de Bonifácio VIII (1294-1303), teve uma ótima atuação política nos conflitos entre os reis da França e da Inglaterra, garantindo a paz entre os reinos. Também durante o seu pontificado, Clemente V (1305-1314) não apenas apaziguou os reis, como suprimiu a Ordem dos Templários no Concílio de Vienne em 1312 e com a bula Ad providam conseguiu transferir os bens dos Templários à Ordem de São João de Jerusalém.

Assim como a Exivi de paradiso, os discursos pontifícios da Quo elongati, da Ordinem vestrum e da Exiit qui seminat sobre a norma franciscana revelaram as estratégias políticas destes papas juristas, especialistas em direito canônico, com o objetivo de formular uma interpretação mais coerente com o momento histórico da Ordem franciscana e com o papel que a Igreja queria lhe dar. Os papas tomavam a decisão de responder por meio de constituições, principalmente aos frades dirigentes, numa tentativa de solucionar os problemas internos da Ordem dos Frades menores ${ }^{281}$. Assim, podemos entender que a redação das bulas por um agente externo era um procedimento eclesiástico de resposta a conflitos internos do movimento Franciscano que vivia em constante transformação e mutação ${ }^{282}$.

${ }^{280}$ Para uma pesquisa mais aprofundada sobre a atuação política de Bertrand de Got, mais
tarde, o papa Clemente $\mathrm{V}$, se faz imprescindível a leitura deste verbete da Enciclopédia
italiana, não apenas pelo fato de ser uma pesquisa atualizada sobre o tema, mas porque traz
uma explicação concisa sobre a trajetória eclesiástica deste primeiro papa de Avignon que
basicamente teve um significativo desempenho político, em parte devido as relações políticas
em que a sua família estava inserida e por outra parte devido a sua habilidade diplomática.
BAGLIANI, Agostino Paravicini. "Clemente V". In: ENCICLOPEDIA dei Papi. Roma: Istituto della
Enciclopedia italiana, 2000, 2v, pp. $501-512$. A análise conservadora de Burgaux não contribuiu
significativamente para o entendimento da atuação política de Clemente $\mathrm{V}$ e de seus
predecessores. BURGAUX, Ch. Histoire des Papes. Versaliis: Persan, 1949 .
${ }_{281}$ MERLO, Grado G. Em nome de São Francisco. História dos Frades Menores e do
franciscanismo até inícios do século XVI. Petrópolis: Vozes, 2005 .
282 Para além da individualidade ou santidade de Francisco de Assis pensamos no movimento
Franciscano como um coletivo heterogêneo, ainda mais no início do século XIV, na nossa
pesquisa interessa-nos os desdobramentos e tensões imbricados no interior da Ordem devido
à interpretação da pobreza normativa. Sem perder de vista que o movimento Franciscano
inseriu-se dentro da perspectiva de movimentos populares italianos da Baixa Idade Média, a
Ordem terceira franciscana absorveu diversos outros movimentos populares nos séculos XIII e
XIV. Segundo Muzzarelli, sem uma organização externa desses grupos penitentes, não era
fácil permanecerem fiéis à ortodoxia. Além da Regra Franciscana de 1223 , a Ordem dos 
Porém, os papas nem sempre redigiam as Cartas pontifícias sem ajuda de outros eclesiásticos, no caso franciscanos. Formava-se uma comissão de frades, capelães papais, entre outros, que colhiam o material a respeito das indagações e pontos controvertidos. O caso de Clemente V seguiu este esquema; uma comissão cardinalícia foi recrutada com o objetivo de rever 0 estado da Ordem e esclarecer quatro pontos: a observância da Regra, as doutrinas de Frei Pedro de João Olivi, as perseguições dos Espirituais da Provença e a infiltração da "seita" do "espírito de liberdade (spiritus libertatis)" entre os Menores. ${ }^{283}$

Os conflitos dentro da Ordem acentuaram-se, principalmente, entre os frades da "Comunidade", o ministro geral frei Gonçalo de Valbona, frei Raimundo de Fronsac, o procurador da Ordem junto à Cúria "romana", frei Buonagrazia de Bérgamo e os frades "Espirituais ${ }^{284 ", ~ o ~ e x-m i n i s t r o ~ g e r a l ~ F r e i ~}$ Raimundo Gaufredi e frei Ubertino de Casale, capelão do poderoso cardeal Napoleão Orsini (que, em 1294, Celestino V havia nomeado protetor dos "pobres eremitas").

Deste modo, depois do "processo contra Bonifácio VIII", com ápice no ano de 1310, a posição dos "Espirituais" franciscanos aumentou com o crescimento do peso "político" de seus cardeais "protetores". Como consequência, Clemente $\mathrm{V}$ publicou em abril de 1310 a Carta Dudum ad

penitentes franciscana tinha o texto Memoriale Propositi ou Regula antiqua Fratrum et Sororum Poenitentiae. Os movimentos laicos penitentes da Baixa Idade Média consistiam em perigo para a autoridade eclesiástica, por isso o esforço em enquadrá-los no seio da Santa Sé, assim como as Ordens Mendicantes. Com isso, o resultado deste esforço eclesiástico foi a incorporação dos Penitentes que foram absorvidos nas Ordens Mendicantes, levando a cabo a autonomia destes grupos, os que não foram enquadrados, tornaram-se heréticos. De nenhuma maneira tivemos um processo linear, de aderência fácil ou desprovido de incoerência. MUZZARELLI, Maria Giuseppina. "Teorie e forme di penitenza in fase di transizione (secoli XIXIII)". In: CAPITANI, Ovidio et al. Dalla penitenza all'ascolto delle confessioni: il ruolo dei Frati Mendicanti. Atti del XXIII Convegno internazionale. Espoleto: Centro italiano di studi sull'alto Medioevo, 1996; Ver também: CASAGRANDE, Giovanna. Un Ordine per i laici. Penitenza e Penitenti nel Duecento. In: MERLO, Grado Giovanni et al. Francesco d'Assisi e il primo secolo di storia francescana. Torino: Einaudi, 1997, p. 237-255.

${ }^{283}$ Os "Espirituais" franciscanos não configuravam numa heresia propriamente dita, na verdade, eles eram dissidentes da Ordem, seguiam o mesmo princípio de pobreza. A Cúria Romana deu o nome de "espirituais" e classificou como heréticos.

${ }^{284}$ Cf. FALBEL, Nachman. Os Espirituais Franciscanos. São Paulo: EDUSP: FAPESP: Perspectiva, 1995, pp. 142 e 143. Sobre a eclesiologia de Ubertino de Casale com a sua obra principal Arbor vitae crucifixae lesi, ver a tese de doutorado de Ana Paula Tavares Magalhães da Universidade de São Paulo, utilizamos nesta dissertação para entender o "partidarismo" dos Espirituais franciscanos, na qual Ubertino de Casale tem um papel prepoderante. MAGALHÃES, Ana Paula Tavares. Contribuição à questão da pobreza presente na obra Arbor Vitae Crucifixae lesu, de Ubertino de Casale. Tese de Doutorado. São Paulo: Universidade de São Paulo, 2004. 
apostolatus, criticando a "Comunidade" por não ter conseguido corrigir os abusos dos frades, elogiou os Espirituais, mas retirou-os da jurisdição dos superiores da Ordem e submeteu-os à autoridade dos cardeais da comissão nomeada pelo próprio papa ${ }^{285}$. Como resultado, os frades reagiram de maneira negativa e o conflito se acentuou entre os grupos. Quanto mais o relaxamento da pobreza na prática aumentava, mais cresciam os partidarismos no interior do movimento Franciscano.

No Concílio de Vienne, realizado de outubro de 1311 a maio de 1312 , Clemente $\mathrm{V}$ procurou conciliar as posições divergentes através da Decretal Exivi de paradiso, aprovada no fim da terceira e última sessão conciliar. $\mathrm{Na}$ ocasião, a Apologia de Boaventura constituiu-se na principal fonte da doutrina da pobreza utilizada por ambos os grupos, assim como a controvérsia em torno do usus pauper do interior da Ordem que havia influenciado o conflito entre os franciscanos e dominicanos. ${ }^{286}$ Nesta nova constituição pontifícia, Clemente $V$ usou o topo de esclarecer as "dubia" sobre a Regra Franciscana de 1223. Como já mencionamos, a redação da Carta não era fruto de uma interpretação isolada do papa acerca da norma dos Menores; era o resultado do trabalho de três anos de uma comissão criada pelo papa Clemente $V$ que ficou encarregada de examinar as acusações recíprocas dos Espirituais e da Comunidade no tocante à pobreza e preparar uma nova declaração papal, além de contar com a participação de péritos em teologia, principalmente, numerosos arcebispos e bispos, cujos nomes não sabemos ao certo.

Segundo Grado Merlo ${ }^{287}$, o mérito da Exivi de paradiso vai além do estilo curial e escolástico; não só apresentava os principais problemas da Ordem naquele período como propunha correções e apresentava definições suficientemente mais precisas e jurídicas num tom disciplinador a respeito dos comportamentos que foram enumerados com clareza.

A Carta Exivi de paradiso foi uma reposta aos frades dada por Clemente $\vee$ na qual isenta os frades da "Comunidade" de qualquer acusação ao seu modo de viver, de ter-se afastado da Regra. Como os seus

\footnotetext{
${ }^{285}$ MERLO, Grado G. Em nome de..., p. 169.

${ }^{286}$ LAMBERT, Malcolm D. Povertà Francescana. La dottrina dell'assoluta povertà di Cristo e degli Apostoli nell'Ordine Francescano (1210-1323). Milano: Edizioni Biblioteca Francescana, 1995, p. 152.

${ }^{287}$ MERLO, Grado G. Op. cit., p. 170.
} 
predecessores, Clemente $\mathrm{V}$ anulou todas as precedentes declarações sobre a Regra e seguiu a tendência de ver a pobreza sob o ângulo jurídico, com o propósito de resolver a discussão na Ordem, que havia se transformado numa verdadeira contenda jurídica ${ }^{288}$. Na verdade, Clemente $\mathrm{V}$ assumiu a argumentação básica de Nicolau III, porém com maiores detalhes a respeito da normatização franciscana.

Podemos separar as tensões no interior da Ordem neste momento, a grosso modo: de um lado, a Comunidade defendia o ponto de vista legal apelando para as declarações de Gregório IX e Nicolau III seguindo uma pobreza mais próxima do plano teórico; de outro, os Espirituais, com exceção de algumas peculiaridades, defendiam a forma de vida conforme a Regra num plano ascético, mais prático do cotidiano, uma pobreza mais rigorosa e argumentavam que esta seria a autêntica pobreza da primeira geração menorita porque, assim como Cristo e os apostólos, Francisco e seus primeiros companheiros teriam vivido sem nada de próprio, fora da institucionalidade.

No início da Decretal, Clemente V colocou o objetivo do seu Decreto, ou seja, uma tentativa de solucionar as diversas interpretações da norma Apostólica a pedido dos franciscanos.

Por las mencionadas declaraciones no han quedado apaciguadas las
conciencias de todos los Hermanos. Persisten las dudas acerca de
ciertos puntos referentes a la Regla y a su tenor de vida. El tema ha
llegado a nuestros oídos en varias ocasiones y ha sido tratado en
varios consistorios públicos y privados. Por tal razón los Hermanos
han humildemente suplicado que apliquemos el remedio oportuno
dando una nueva aclaración ante las dudas que se han ido
suscitando y ante las que podrían aparecer en el futuro. ${ }^{289}$

Assim como os seus predecessores, Clemente $\mathrm{V}$ mencionou conhecer a verdadeira intentio do bem-aventurado Francisco, que seria o único autor da Regra Franciscana de 1223, a "lex fundamentalis" dos que querem seguir a Ordem Franciscana.

Comprobamos que tal ha sido la intención del bienaventurado Francisco, autor de la Regla, por el hecho que haber mencionado en la regla algunos consejos evangélicos, omitiendo otros. Es naturaleza propia de una ley restrictiva excluir todo lo que no está explícitamente

\footnotetext{
${ }^{288}$ HARDICK, Lothar. "Pobreza, pobre". Op. cit., p. 597.

${ }^{289} \mathrm{O}$ grifo é nosso para enfatizar os termos utilizados pelo papa. Utilizamos aqui uma versão espanhola da Exivi de paradiso de Clemente V, disponível em: <http://www.franciscanarchive.org/documenta.html> Acesso em: 20 out. 2009.
} 
mencionado como inherente a la ley. Por eso nosotros declaramos y afirmamos que los Hermanos están obligados por la profesión de su regla no solamente a los tres votos tomados en sí mismos, sino también a todas las cosas que se les están relacionadas y que están explícitamente contenidas en la regla. ${ }^{290}$

No trecho a seguir, Clemente $\mathrm{V}$ evidencia que a sua interpretação jurídica da norma seguiria a linha de Nicolau III; os frades seriam obrigados à observância da Regra, apesar de colocar uma distinção entre o que seria obrigatório, admonitório e exortatório.

Duda que está lejos de aclararse. Al revés, más bien se ha acrecentado con las declaraciones de nuestro predecesor Nicolás III. El afirma que los Hermanos están obligados en virtud de la Regla a aquellos consejos evangélicos que aparecen en la Regla con expresiones preceptorias o inhibitorias o análogas. De igual modo están obligados a la observancia de todo lo que en la Regla está expresado con fórmulas obligatorias. [...] De por sí los Hermanos no están obligados a la observancia de todo que está expresado en la Regla con verbos en imperativo, como si se tratasen de preceptos o de términos equivalentes. ${ }^{291}$

Neste excerto, o papa organizou mais precisamente em forma de resumo os principais pontos obrigatórios da normatização franciscana que os frades deveriam seguir no seu cotidiano, para depois comentar cada ponto isoladamente.

[...] no tener varias túnicas sino una con capucho y otra sin capucho, no llevar calzado, que los hermanos se vistan de ropas viles, la obligación de ayunar desde la fiesta de todos los santos hasta la navidad del Señor y los viernes, los clérigos hagan el oficio divino según el orden de la santa iglesia Romana, que los ministros y los custodios cuiden de la necesidad de los enfermos y del vestido de los hermanos, si algún hermano cayere en enfermedad, otros hermanos deben servirle, los hermanos no prediquen en el obispado de algún obispo cuándo éste se lo prohiba, nadie se atreva a predicar al pueblo sino fuere examinado, aprobado e instituido por el Ministro General o por quiénes tuvieren esa competencia según la declaración mencionada, que los hermanos que vieren no poder observar la Regla deban y puedan recurrir a sus ministros, todo lo que establece la regla en orden al hábito y profesión de los novicios y profesos, así como todo lo que se refiere al modo de la recepción y profesión, a no ser que, tal como dice la regla, otra cosa según Dios les pareciere, a los encargados de recibir los novicios. Todas estas cosas han de ser observadas por los hermanos como obligatorias. ${ }^{292}$

290 Disponível em: <http://www.franciscan-archive.org/documenta.html> Acesso em: 20 out. 2009.

${ }^{291}$ Exivi..., IDEM, Ibidem.

292 IDEM, Ibidem. 
Porém, ao estabelecer que os frades possuíam a liberdade de escolha para seguir o modo de vida franciscano, Clemente $V$ instituiu uma pobreza moderada e ponderada, sem o rigor defendido pelos Espirituais.

La misma Regla quiere que los que ingresan en la Orden se sientan libres de hacer con sus cosas lo que el Señor les inspirare. Por lo cual, si el que ingresa en la orden quisiera dar libremente algo a los hermanos, tal como los hace con los demás pobres, no parece que sea ilícito recibirlo, siempre que se tenga en cuenta la necesidad y la moderación expresadas en la declaración ya aludida. ${ }^{293}$

Nesta outra parte da Exivi de paradiso, Clemente $\mathrm{V}$ determinou o que seria preceito no sentido de norma básica, anulando a resolução de Nicolau III da Exiit qui seminat no tocante às vestes, revogando o trecho em que o outro papa permitia a concessão de várias túnicas. Clemente $\mathrm{V}$ revogou a Regra de 1223 no capítulo dois, que só permitia o uso de duas túnicas, uma sem capuz e outra com capuz, além de permitir que a rusticidade das vestes e o uso ou não de calçados ficassem a critério do ministro provincial, uma decisão descentralizada, sem a intervenção do ministro geral.

\begin{abstract}
Declaramos que tales palabras se equiparan a preceptos. De todos modos queriendo determinar esta materia de modo más seguro y declaramos: en cuanto al número de las túnicas, no es licito usar más de las que mencionadas en la Regla, a no ser en caso de necesidad, según lo que nuestro predecesor ya declaró detalladamente; en relación a la vileza de los vestidos, tanto del hábito como de la túnica interior, declaramos que tal vileza (vulgaridad o baratura) ha de ser entendida de acuerdo a las costumbres o condiciones de la región, tanto en lo referente al color del paño como a lo barato del precio; no es posible dar criterios de vileza comunes a todas las regiones; El juicio acerca de la vileza lo encomendamos a los ministros, custodios y guardianes, cargando sus conciencias, de modo que sea efectivamente observada la vileza en los vestidos; también dejamos a juicio de los ministros, custodios y guardianes, el determinar cual sea la necesidad que haga licito llevar calzado a los hermanos. ${ }^{294}$
\end{abstract}

A partir deste ponto, Clemente $\mathrm{V}$ expôs mais explicitamente os problemas internos da Ordem franciscana verificados naquele momento, os conflitos entre os frades da Comunidade e os Espirituais franciscanos em relação à concepção de pobreza da Regra e declarou uma resolução para o embate. Entretanto, o mais interessante, sobretudo na Exivi foi, sem dúvida, a lista dos abusos ou erros cometidos em determinados conventos do início do século XIV revelados pelos Espirituais. Clemente $\mathrm{V}$ revelou as práticas

293 IDEM, Ibidem.
294 IDEM, Ibidem. 
cotidianas que alguns conventos adotaram: eram concessões em demasia, o que afastava da pobreza estabelecida pela Regra, o que justificaria o descontentamento dos "Espirituais franciscanos". Como nos aponta Nachman Falbel $^{295}$, a bula repete em detalhes as transgressões à Regra e a devida condenação, influência das críticas levantadas pelo "espiritual" Ubertino de Casale.

\begin{abstract}
La situación derivante de esta disposición fue sometida a nuestro examen, dado que algunos en la orden afirman que su consecuencias repugnan a la pureza del voto y de la orden. Ante aquellos que procuran y sienten ser los herederos de tales bienes queremos poner el necesario remedio, señalando los siguientes abusos: Algunos conventos cubren todas sus necesidades con la notable cantidad de intereses anuales percibidos. Otros viven agitados por sus negocios en bienes temporales, haciéndose defender por abogados y procuradores, y haciéndose representar personalmente en los litigios. Reciben y gestionan la ejecución de los testamentos, y a veces se entrometen en negocios usurarios 0 en disponer 0 retribuir malamente los bienes robados. En algunos lugares no solamente tienen huertas excesivas sino también grandes viñas, de las cuales recogen mucho vino y aceite para la venta. En la época de la vendimia y de la cosecha recogen mendigando o comprando tan gran cantidad de vino y de grano, que, guardados luego en graneros y despensas por los hermanos, les permiten pasar su vida el resto del año sin recurrir a la mendicación. Buscan construir sus iglesias y demás edificios con tal grandeza y curiosidad de forma y estilo, y con suntuosidad tan notablemente excesiva que no parecen habitación de pobres sino de magnates. En muchos lugares poseen ornamentos eclesiásticos en tan gran número y tan notablemente preciosos como para sobresalir en relación a las grandes iglesias catedrales. Indistintamente reciben donaciones de caballos y de armas. ${ }^{296}$
\end{abstract}

A lista acima mencionada é bastante interessante nela percebemos que a prática da pobreza absoluta era impraticável; muitos conventos viviam como os demais mosteiros tradicionais, vendiam vinhos, estabeleciam negócios temporais inclusive com usurários, outros tinham hortas em excesso, azeites e vinho, construíam igrejas suntuosas que estavam longe de serem pobres, recebiam doações de cavalos e armas. Assim, alguns conventos tinham um acúmulo de objetos, comida e faziam comércio local, o que contradiz a Regra de 1223, o princípio básico de não ter propriedades nem em comum e nem individual, não lidar com dinheiro e não acumular comida ou qualquer outro objeto.

\footnotetext{
${ }^{295}$ FALBEL, Nachman. Op. cit., p. 142.

296 Disponível em: <http://www.franciscan-archive.org/documenta.html> Acesso em: 20 out. 2009.
} 
Mais adiante, Clemente $\mathrm{V}$ estabeleceu uma lista de medidas que deveriam ser seguidas para se corrigirem os abusos acima expostos. Por exemplo, os conventos não poderiam instituir herdeiros de qualquer coisa que fosse, visto que isso acarretaria um reconhecimento do direito de propriedade, o que contraria a base da identidade Franciscana exposta na Regra, o princípio de não ter propriedade sobre coisa alguma e não acumular nada. Além disso, os frades não poderiam lidar com o dinheiro, muito menos vender qualquer coisa que fosse porque iria contra o capítulo quatro, que prevê que os frades não recebam dinheiro. Enfim, juridicamente era para evitar a acumulação de bens e não ter a posse de nada porque isso configurava um preceito obrigatório.

\begin{abstract}
Deseando nosotros precaver la conciencia de dichos hermanos, y remover, en cuanto posible, toda duda de sus corazones, respondemos del modo siguiente: Es necesario que el fuero externo de los hermanos represente el hábito y la disposición interna de la mente, porque tal es la exigencia de la verdad de la vida. Deberán, pues abstenerse de todo lo que pueda ser o parecer contrario a la renuncia que han hecho, en vistas a una expropiación tan especial de las cosas temporales. Dado que en las sucesiones pasa a los herederos no solamente el uso sino también el dominio de los bienes, los hermanos no podrán adquirir bienes por herencia ni en privado, ni como orden en común. En este campo, por su naturaleza propia, es indiferente que el legado sea en dinero 0 en bienes muebles 0 inmuebles. Son absolutamente incapaces de heredar en virtud de la pureza del voto. También simplemente prohibimos por considerarlo no lícito, recibir el valor de la herencia o parte del mismo - los cual se puede presumir como recepción fraudulenta - haciéndose remitir y recibiendo luego lo remitido, bajo forma de un legado. Los intereses anuales de los bienes inmuebles y el derecho adquirido sobre tales intereses, han de ser elencados entre las cosas que repugnan a la pobreza y a la mendicidad. No cabe duda alguna que no es lícito a quien fuera de tales hermanos recibir ni la posesión ni el uso de bienes con tal condición, dado que esto no están indicado en ninguna concesión pontificia. ${ }^{297}$
\end{abstract}

Para Malcolm Lambert, as constituições papais teriam sido mal interpretadas pelos frades dos séculos XIII e XIV. Por exemplo, segundo Ubertino de Casale, os privilégios papais teriam assegurado cobertura às várias formas de relaxamento da pobreza normativa e, além disso, ele estabeleceu uma diferença entre duas formas de vida franciscana: uma era a autorizada pelos privilégios papais e a outra era aquela imaginada por

297 Disponível em: <http://www.franciscan-archive.org/documenta.html> Acesso em: 20 out. 2009. 
Francisco e os primeiros companheiros. ${ }^{298}$ Nem tão longe de Ubertino e nem tão perto de Boaventura, o fato é que a cada constituição papal promulgada, mais aumentavam os conflitos e tensões no interior da Ordem Franciscana. As constituições papais não resolviam os problemas internos dos Menores, ao contrário, acentuavam-se os debates acalorados sobre a pobreza normativa e as disputas internas de como elas deveriam ser aplicadas. Para Ubertino de Casale, a única forma de "reforma" possível era retornar para a "observância" literal da Regra. Afinal, os abusos davam-se em razão dos privilégios papais concedidos ou por indivíduos isolados, e o que seria a prática da observância na doutrina da pobreza absoluta?

A resposta talvez aparecesse no final da Exivi, Clemente V, ao resgatar o conceito de usus pauper, trouxe os limites deste conceito. Ele interpretou 0 uso pobre no sentido da "Comunidade" ao abordar que os frades não deveriam seguir a observância de todos os conselhos evangélicos, mas somente aqueles expressos na Regra na qual percebemos uma pobreza mais ponderada. Então, para o papa o "uso pobre" das coisas era no sentido de moderação e não no sentido do criador do conceito - Pedro de João Olivi, que pensava numa pobreza ascética com o uso estritamente pobre das coisas na prática cotidiana.

De todo lo dicho en páginas anteriores, surge una cuestión bastante enojosa entre los hermanos, a saber: si por la profesión de su regla están obligados a un uso de las cosas estrecho, exiguo y pobre. Algunos creen y afirman que así como en relación a la propiedad de las cosas están obligados en razón del voto a una renuncia estrictísima, del mismo modo la estrechez del uso también ha de ser máxima y que no hay argumentos en contrario. Otros, al revés, sostienen que no están obligados por su profesión a ningún tipo de uso pobre, fuera del expresamente mencionado en la Regla. Por más que estén, sí, convenientemente obligados al uso moderado que supone la temperancia, a igual o mayor título que los demás cristianos. Queriendo proveer a la tranquilidad de las conciencias de estos hermanos, y poner fin a estos altercados, declaramos: Los hermanos Menores están especialmente obligados, en razón de su profesión, al uso pobre o estrecho que está expreso en su misma regla, y con las modalidades que en ella constan. Es presuntuoso el afirmar, como algunos pretenden, que es herético sostener que el uso pobre está o no está contenido en el voto de pobreza evangélica. ${ }^{299}$

Como vimos, Clemente $\mathrm{V}$ definiu uma pobreza franciscana no sentido de moderação (usus moderatus) e temperância, lembrando muito a análise de

\footnotetext{
${ }^{298}$ LAMBERT, Malcolm D. Op. cit., p. 182.

299 Disponível em: <http://www.franciscan-archive.org/documenta.html> Acesso em: 20 out. 2009.
} 
Nicolau III. A propriedade dos bens franciscanos continuava pertencente à Santa Sé. Neste momento, os frades só possuiriam o direito de uso das coisas e muitos conventos estavam infrigindo esta norma. Enfim, Clemente $V$ não aceitou todas as reinvidicações dos Espirituais, principalmente a ideia de se separarem da "Comunidade", criando uma Ordem própria que seguisse uma pobreza mais rigorosa. A bula Exivi de paradiso foi uma tentativa de conciliar as duas diferentes concepções de pobreza dos dois grupos de Frades menores, porém após a sua promulgação em 1312 os ânimos acirraram-se mais intensamente. Para todos os franciscanos a pobreza era uma condição necessária para se atingir a perfeição evangélica, por isso as divergências e a importância de uma definição papal.

A exclusão dos Espirituais do seio franciscano iniciou-se com Clemente V, com a subordinação destes aos Conventuais e a condenação de Pedro de João Olivi e dos fraticelli. Da polêmica dos dois grupos à complexidade da questão, o ideal de pobreza mais rigorosa dos Espirituais estava distante da concepção que a Igreja permitia aos grupos religiosos. Ademais, a discussão estava longe da questão da experiência religiosa de Francisco e seus primeiros companheiros, o debate restringiu-se a uma disputa em torno da codificação desta experiência que se encontrava na Regra de 1223 e à problemática discussão que ficava somente no plano teórico de como esta deveria ser interpretada.

Basicamente, podemos resumir que a Decretal Exivi de paradiso tratou de questões disciplinares em relação à Ordem Franciscana a respeito dos problemas apresentados no início do século XIV. Esta bula de Clemente V tentou apaziguar as disputas internas entre os frades da Comunidade e os frades Espirituais. Assim como os seus predecessores, Clemente $V$ não resolveu a questão de interpretação jurídica da norma, acentuando o conflito que culminaria com a negação de identidade aos Espirituais franciscanos e a crise institucional da Ordem Franciscana, sobretudo no pontificado de João XXII (1316-1334) $)^{300}$.

Enfim, no pontificado de Clemente $V$ começou a perseguição aos Espirituais, o Concílio de Vienne condenou João de Olivi porque ele afirmava

${ }^{300}$ FALBEL, Nachman. Op. cit., pp. 143-144. 
que Cristo não possuia bens nem individualmente nem coletivamente. Entre outros erros apontados, Olivi sustentou que o papa não tinha autoridade para interpretar a Regra de Francisco. Anteriormente, em 1294, outros franciscanos haviam sido condenados por causa desta concepção de pobreza, como Pedro de Macerata (Frei Liberato) e Pedro de Fossombrone (Frei Angelo Clareno). Clemente $\mathrm{V}$ também condenou os fraticelli e beguinos como heréticos. Com estas medidas, o papa pareceu ter antecipado o que viria acontecer alguns anos depois: a condenação do paradigma de pobreza franciscana. Ele sinalizou o argumento da heresia que foi usado por João XXII.

Em suma, a Exivi de Clemente $\mathrm{V}$ foi organizada por meio de sutilezas jurídicas numa distinção entre o que era preceito, exortação ou admoestação e o que deveria ser obrigatório., além de explicitar os abusos de alguns conventos franciscanos e como estes deveriam ser corrigidos. Como bem nos coloca Grado Merlo ${ }^{301}$, assim como outros pronunciamentos pontifícios acerca da Regra, a interpretação jurídica de Clemente $V$ não resolveu os problemas internos da Ordem franciscana. Contudo, o mérito da Exivi de paradiso não estaria só no estilo curial e escolástico, mas no fato de não esconder os problemas da Ordem no início do século XIV e de chegar a definições mais precisas a respeito dos comportamentos enumerados com clareza. Enfim, também estabeleceu que a pobreza permitida pela Igreja seria aquela tradicional das outras Ordens e menos rigorosa na prática assim como era para os demais grupos religiosos.

\subsection{A crise institucional da Ordem: João XXII (1316-1334) e a negação do paradigma de pobreza franciscana em 1323}

De Gregório IX a João XXII, a questão da pobreza foi sendo debatida através de bulas que se propunham a fazer exegeses da norma franciscana por meio de sutilezas jurídicas de acordo com o momento histórico da Ordem. Assim, tivemos a criação de novos conceitos de pobreza, a saber, a commoda fratrum, o usus pauper, o usus moderatus, o usus facti, o ius utendi, o simplex usus facti e o simplex usus. Conceitos que convergiram para um lento

${ }^{301}$ MERLO, Grado G. Op. cit., pp. 164 e 170. 
deslizamento de reflexões da pobreza vivida para a pobreza pensada, já que o ponto de referência não era mais a experiência religiosa de Francisco, mas a codificação da experiência que se encontrava na Regra e na problemática discussão de como esta deveria ser aplicada no cotidiano dos conventos. Como resultado, o movimento Franciscano foi enquadrando-se nos moldes das demais instituições religiosas tradicionais e a pobreza da Regra foi permitida aos Frades menores pela Igreja somente no plano simbólico ou teórico e não na prática, equiparando os Menores às outras Ordens religiosas do Ocidente Medieval latino. Porém, no pontificado de João XXII a questão da pobreza franciscana teve um desfecho trágico, o que provocou uma grave crise na instituição e o encerramento do debate teórico em torno da paupertas franciscana.

Segundo a Enciclopedia dos papas ${ }^{302}$, Jacques Duèse nasceu em Cahors no ano de 1244. Ele foi eleito papa no dia 7 de agosto de 1316. A sua eleição papal foi extremamente complexa depois de uma vacância de dois anos da Sede pontifícia. Teve uma formação jurídica adquirida nas cidades de Cahors, Montpellier, Orléans, onde conseguiu o título de doutor "in utroque jure", estudou também teologia em Paris. Foi docente em direito civil em Tolosa, arcipreste de Cahors, cônego de Saint Front de Périgueux, arcipreste de Sarlat, cardeal titular de S. Vital, atuou no processo de Bonifácio VIII e no Concílio de Vienne etc.

No pontificado de João XXII (1316-1334) o debate da paupertas franciscana atingiu o seu ápice e ao mesmo tempo encerrou-se. $O$ ponto culminante a respeito da discussão da pobreza foi provocado pela concepção diferente dos dominicanos e dos franciscanos a respeito da perfeição evangélica. Segundo Lothar Hardick ${ }^{303}$, a querela teria sido iniciada com o inquisidor dominicano João de Belna, em 1321, ao interrogar um beguino. Um dos erros encontrados pelo inquisidor foi no tocante ao conceito de propriedade. $\mathrm{O}$ beguino estava convencido da opinião de que Jesus Cristo e os seus apóstolos nada possuíam em comum nem em particular, o que é a premissa da Regra franciscana de 1223. Os Frades menores recorreram ao

\footnotetext{
302 TROTTMANN, Christian. "Giovanni XXII". In: ENCICLOPEDIA dei Papi. Roma: Istituto della Enciclopedia italiana, 2000, 2v, pp. 512 e 513.

${ }^{303}$ HARDICK, Lothar. Op. cit., p. 598.
} 
papa João XXII ${ }^{304}$ contra a sentença de João de Belna porque, para os franciscanos, não ter propriedade de nada era a Imitatio Christi, Cristo e os apostólos não teriam nada de próprio e nem em comum. João XXII apoiou a decisão dominicana. Para Malcolm Lambert ${ }^{305}$ a controvérsia doutrinal sobre a pobreza de Cristo teve início em 1321 com o interrogatório de João de Belna ao beguino porque, ao invés do inquisidor pronunciar a sentença, ele reuniu um consilium de notáveis, juristas e eclesiásticos, no qual leram as teses condenadas. Berenger Talon, lector do convento franciscano de Narbona e membro do consilium, objetou que a doutrina da absoluta pobreza era herética, citando a bula Exiit qui seminat. João de Belna acusou-o de heresia e Berenger Talon apelou ao papa, que deu razão ao dominicano.

Logo em seguida João XXII publicou, no dia 4 de junho de 1322 a bula Quia nonnunquam, na qual o papa consentiu no exame do decreto da Exiit de Nicolau III para que ele tivesse o direito de esclarecer os conteúdos menos patentes sobre os pontos controversos da pobreza. No texto da Quia nonnunquam, João XXII insistia no seu próprio direito de modificar as bulas dos predecessores segundo a sua própria vontade. Nas palavras de abertura: "Poiché, a volte, ciò che le congetture giudicavano essere causa di vantaggio, la succesiva esperienza ha dimostrato essere dannoso, non si dovrebbe considerate biasimevole, se il legislatore prendesse di revocare canoni promulgati da lui stesso o dai suoi predecessori, qualora li giudicasse dannosi, piuttosto che vantaggiosi...", a Exiit qui seminat era a pedra angular sobre a qual se apoiava a posição da Ordem e a Exiit estava inserida no direito canônico; por isso o papa não podia revogá-la ${ }^{306}$.

No Capítulo geral de Perugia de 1322, os frades conceberam uma circular ("manifesto franciscano de Perugia de 1322") combatendo a ameaça dos confrontos sobre a doutrina da Ordem dirigida a toda a cristandade declarando que a concepção franciscana de pobreza tinha sido determinada como doutrina de fé mediante a decretal Exiit qui seminat, e quem não aceitasse esta concepção estaria em contradição com a doutrina da Igreja ${ }^{307}$. A Exiit, que desenvolveu o conceito de simplex usus facti a partir da Apologia de

\footnotetext{
304 TROTTMANN, Christian. Op.cit., p. 512.

305 LAMBERT, Malcolm D. Op. cit., pp. 216 e 217.

${ }^{306}$ LAMBERT, Malcolm D. Op. cit., p. 221.

${ }^{307}$ MERLO, Grado G. Op. cit., p. 176.
} 
Boaventura de Bagnoregio, sustentava que os franciscanos tinham renunciado a todos os direitos civis e conservado somente o simplex usus facti dos seus bens. No entanto, a enciclica dos frades modificava a doutrina portando e aplicando o simplex usus facti à vida de Cristo e dos apóstolos; desta forma, modificava os textos escriturísticos "não franciscanos". Assim, Cristo e seus apóstolos portavam a bolsa ou quando, na Igreja primitiva, os apóstolos tinham as coisas em comum, agiam somente na qualidade de administradores ("ut meri et nudi administratores"); eles teriam renunciado a todos os direitos do ius civile e conservado para si somente o simplex usus facti. Esse "manifesto" foi assinado pelo ministro geral Miguel de Cesena, pelos ministros das Províncias da Inglaterra, da Alemanha "superior", da Aquitânia, da França, de Bolonha, de São Francisco, de Castela e de "Touraine" ${ }^{308}$.

Concorditer et unanimiter dicimus et fatemur quod dicere et adserere quod Christus, viam perfectionis ostendens, et apostoli, eiusdem perfectionis viam sequentes atque per exemplum in alios, volentes perfecte vivere, derivantes, nihil iure proprietatis, dominii seu iuris proprii, in speciali vel in communi habuerint, non est haereticum, sed sanum, catholicum et fidele, maxime cum sancta Romana ecclesia catholica [...] expresse dicat, affirmet ed determinet manifeste. ${ }^{309}$

Como vimos, a "leitura" da pobreza do "manifesto" era da seguinte maneira: para atingir-se a via da perfeição seria necessário seguir Cristo e os Apóstolos, que nada tiveram nem em particular e nem em comum por razão de propriedade, de domínio e de direito próprio, e isso não é herético, mas sadio, católico e fiel porque a Santa Igreja católica já havia afirmado o princípio da absoluta pobreza de Cristo e dos apóstolos conforme a Exiit qui seminat e a Exivi de paradiso.

A resposta do papa João XXII às teses do "manifesto", que ele não partilhava, foi através de dois documentos. O primeiro foi promulgado no dia 8 de dezembro de 1322, a bula Ad conditorem canonum de João XII foi uma negação de todo direito de propriedade dos bens que vinham sendo usados pelos frades e proibiu que os mesmos pudessem no futuro instituirem procuradores. A Ad conditorem canonum foi fixada nas portas da igreja de Avinhão. Em seguida, frei Buonagracia de Bérgamo, procurador da Ordem,

\footnotetext{
${ }^{308}$ MERLO, Grado G. Op. cit., p. 177.

${ }^{309}$ IDEM, ibidem.
} 
tentou produzir um apelo e protesto no dia 14 de janeiro de 1323; em resposta, João XXII mandou prendê-lo por um ano, depois republicou a Ad conditorem canonum numa segunda versão com o objetivo principal de negar a noção do "simplex usus facti"310. A nova redação apresenta-se muito meditada e comprometida no plano da doutrina jurídica, num jogo de palavras, João XXII iniciou a sua bula argumentando que os estatutos emitidos pelos papas predecessore, ao invés de promoverem ajuda, mais causaram danos. Ele reafirmava com maior ênfase o direito de anular a declaração de seus predecessores.

\begin{abstract}
There is no doubt that it is the business of the maker of the canons to take action when he sees that statutes issued by himself or by his predecessors harm rather than help, before they can do further harm. Provisions made by Pope Nicholas III in Exiit.

Some time ago our predecessor of happy memory Nicholas III, seeing with attentive foresight that the Rule of the gracious confessor blessed Francis laid down that professed members of his order "should not make anything their own, neither house, nor place, nor any other thing", and carefully considering that pope Gregory IX of pious memory and some other predecessors of the same [i.e. of Nicholas III] had declared that this [not making anything their own] should be observed "both individually and in common", and noting thoughtfully as well that some have criticised the Brothers, urging against them that they were not observing the Rule and such declarations [as Gregory's], and dutifully purposing to close the mouths baying against those Brothers and to provide for the consciences of the professed members of the Order themselves, ordered and enacted, among other things, that the ownership and lordship of all equipment, books, movable things, both present and future, and also of all churches, chapels and cemeteries, both present and future, and also of other purchased things, and of things offered in divine alms or granted to the said brothers (in which, however, the offerers or granters decide not to reserve anything to themselves), belongs fully and freely to himself and to the Roman Church, accepting those things to himself and that Church, reserving to the Brothers only simple use of fact in such things and goods. ${ }^{311}$
\end{abstract}

João XXII enumerou as decisões dos papas Gregório IX e Nicolau III para depois, logo em seguida, revogá-las por meio de objeções. Assim, partindo da Regra franciscana da premissa de não ter propriedades nem

\footnotetext{
${ }^{310}$ LAMBERT, Malcolm D. Op. cit., p. 220.

${ }^{311}$ O grifo é nosso para enfatizar os termos empregados. João XXII reafirmou o direito de papa, como "conditor canonum", de corrigir cânones anteriores quando se tonarem mais nocivos do que úteis. Isso aplicava-se a Exiit qui seminat de Nicolau III, cujas afirmações e decisões teriam tido efeitos negativos, tanto sobre o estado de perfeição dos Frades menores, como sobre a honra da Igreja. A cobertura jurídica e ideológica a uma realidade quer era bem diferente, ao menos no plano teórico, afirmavam os Menores, os quais mostravam uma solicitude em relação aos bens temporais certamente não menor do que as outras Ordens mendicantes, que também tinham posses em comum. Bula "Ad conditorem canonum" de João XXII. Disponível em: <http://www.humanities.mq.edu.au/Ockham/wadc.html> Acesso em: 20 Agos. 2010.
} 
individuais nem comuns, sendo a Santa Sé detentora de todos os bens dos frades e o procurador nomeado responsável por lidar com o dinheiro da Ordem, estando de acordo com o cardeal protetor, poderiam trocar e vender os bens móveis conforme o papa recordou.

But also, since their Rule strictly forbids the Brothers to accept money, directly or through another, he [Nicholas] willed and granted that, if the movable things referred to come to be sold for an estimated price, this price should be received through a procurator by the before mentioned See or by the Cardinal Governor [protector] of the same Order, to be allocated by the same procurator for spending on a licit thing the use of which would be permitted to the Brothers of the same Order: adding this, that concerning paltry movables or things of small value, the Brothers (having obtained, however, their superiors' permission on this matter), could, with a view to piety or devotion or for some other decent and reasonable cause, give them away, either within or outside the order. ${ }^{312}$

Em seguida concluiu que o estado de perfeição de pobreza dos Menores estava incorreto e alegou ser impossível sua praticabilidade. A "reservatio domini" da Igreja de Roma não incluíra uma verdadeira e própria "expropriatio" dos frades, que continuavam a dispor de bens que certamente usavam, mas que, em alguns casos, podiam também vender e doar.

[The Brothers have not been freed from solicitude] Indeed, the above mentioned reservation of lordship [to the Roman Church] has by no means benefited the Brothers in respect of the state of perfection; for since the perfection of Christian life principally and essentially consists in charity-which the Apostle calls the bond of perfection, which unites or in some measure joins man, while on the way [i.e., in this life], to his end. Contempt of temporal goods and renunciation of ownership of them opens the way to this perfection especially because the solicitude that acquiring, preserving and dispensing temporal things requires, which commonly impedes the act of charity, is cut off. It follows that if the same solicitude persists after such divestment of ownership as existed before it, such divestment can contribute nothing to such perfection. But it is certain that after the above ordinance the Brothers were no less solicitous in acquiring and preserving those goods, in court and otherwise, than they had been before it, or than other mendicant religious who have some things in common.

[They have not been made poorer] Besides, the above mentioned ordinance has not, in any case, benefited the said Brothers by enabling them on account of lack of such ownership to call themselves poorer than if they were to possess those things together with (what they say they lack) lordship [of them]. For although our predecessor thought that the lordship of things that happened to be offered or granted, or come in some other way, to the Brothers-but [things] of which the Order, or the Brothers, are permitted to have use of fact-should be taken to himself or to the Roman Church, with simple use of fact reserved to the Brothers, and decreed that [the lordship

${ }^{312}$ IDEM, Ibidem. 
thus] pertains freely [to himself and the Roman Church], as has been stated above, nevertheless, in view of the Brothers' manner of using, and its effect, and the subsequent forbearance of the Roman Church concerning that manner, it is not the Brothers' use but rather the lordship of the Roman Church that should be called "simple". ${ }^{313}$

João XXII argumentou que a questão de separação do usus e proprietas era impossível e que o "usus facti" se oporia à lei, somente o "usus simplex" podia pertencer à Ordem, que teria a propriedade das coisas. Como bem nos coloca Merlo, "o testemunho cristão era examinado por rigorosos critérios e fechados raciocínios jurídicos não só porque o papa era um jurista, mas porque instituições e homens da Igreja nutriam-se do pensamento jurídico há quase três séculos. Se acrescentarmos que a hierocracia pontifícia incluía o controle do direito canônico e civil, compreende-se bem que os princípios de um não podiam conflitar com os princípios do outro. A opção franciscana era uma exceção não admissível". Assim, ao revogar as providências da Exiit, João XXIl estava anulando a "reservatio dominil" da Igreja sobre os bens dos frades, excetuando as igrejas, os oratórios, as oficinas, as habitações e vasos, livros e paramentos destinados ou a serem destinados ao ofício divino, e justificava que a esses bens destinados ao exercício das funções divinas não era aplicável o conceito de "usus facti", por isso, eram submetidos a um regime jurídico especial ${ }^{314}$. Ou seja, a redação do texto foi bastante articulada, particularmente quanto à impossibilidade de perceber o uso separado do domínio em referência aos bens duráveis e, sobretudo, aos bens consumíveis como vemos abaixo.

[Use of consumables without ownership is impossible] But that these Brothers should not be regarded as usuaries in respect of things that are consumed by use appears clearly enough from the following. To say, indeed, that in such things it is possible to establish use of right, or of fact, separate from ownership of the thing, or lordship, is opposed to the law, and conflicts with reason; and it does not seem to have been the intention of our predecessor to reserve lordship of such goods to the Roman Church. For what sane person could believe that it was the intention of so great a father to keep the lordship for the Roman Church, and the use for the Brothers, of an egg, or a cheese, or a crust of bread, or other things consumable by use, which are often given to the Brothers themselves to consume on the spot? Truly, it does not seem probable, especially since he reserved to the Roman Church the lordship only of those goods of which simple use of fact can belong to the Brothers of the said Order. This can by no means

\footnotetext{
313 IDEM, Ibidem.

${ }^{314}$ MERLO, Grado G. Op. cit., p. 179.
} 
be found in things consumable by use, in which neither a right of using, nor a use of fact, separate from ownership of the thing or lordship can be established or had.

And he shows evidently that he did not refer to such things when he answers the law that says that usufruct cannot be permanently separated from lordship, lest the lord's lordship, with the use always escaping [abscedens: "existing separate" (gloss)], be made useless. Indeed, that law is understood of those things of which the use can remain with one person and the lordship, though useless, with another. That can by no means be the case in things consumable by use, since in these, through the usuary's use (or "abuse"), the substance of such a thing ceases to exist, and consequently ownership, even useless, does not subsist. ${ }^{315}$

João XXII eliminou a proteção disciplinar e o fundamento jurídico sobre o qual se apoiava o conceito (ou a exceção) franciscano da pobreza, assim tornou-se impossível dar a propriedade dos bens para a Igreja e, portanto, os frades teriam a propriedade das coisas adquiridas porque não havia a possibilidade de separar o uso da propriedade.

[It is impossible to give the act of using to another person] And that such use cannot be established appears from this, that no one can give, or establish, what is not his and does not belong to him, although sometimes he can give it in another way than it is his [e.g. dominus can give the usufruct]. But the act itself of using belongs to the user, in as much as one is said to be lord of one's own acts through free choice and will, since through this one can not perform them, or also perform them: but the act itself of using does not pertain to him who grants to another that he be able to perform that act on his thing. This [grant] indeed is nothing else but that the user can apply his act to the thing belonging to the person granting it to his act: just as he who lends his horse to someone does not grant the borrower the act of riding, but that he can perform that act on his horse. This is certainly not to grant a simple act of using without a right, since to grant this [haec: substitute hoc] is nothing else but to grant a right of using. Indeed, in things consumed by use this right of using cannot be established in separation from ownership or lordship, as appears more clearly from the foregoing. [...]

[An act without a right cannot belong to a state of perfection] Moreover, if simple use without a right of using can be had by anyone, it is certain that such an act of using would have to be regarded as not just, since someone will have used to whom a right of using did not belong. But such a not-just use by no means pertains to the state of perfection, and does not add anything of perfection, but rather is manifestly known to conflict with it and detract from it. ${ }^{316}$

As resoluções da Exiit teriam prejudicado a própria Igreja segundo João XXII por isso ele estava cancelando toda as medidas referentes a propriedade e portanto, a Santa Sé não era mais detentora dos bens da Ordem franciscana.

\footnotetext{
315 Bula "Ad conditorem canonum" de João XXII. Disponível em: $<$ http://www.humanities.mq.edu.au/Ockham/wadc.html> Acesso em: 20 Agos. 2010.

${ }^{316}$ IDEM, Ibidem.
} 
Enfim, a partir deste momento os frades possuiam bens e inicia-se a crise institucional da identidade franciscana.

[The arrangements made in Exiit have damaged the Church] Again,
not only has the above mentioned ordinance [Exiit] not benefited the
Brothers themselves, but it also occasions, and has occasioned, not
inconsiderable damage to the honour of the Holy Roman Church [...]
we strictly prohibit that henceforth anyone be nominated by anyone or
established from now on as procurator in the name of the holy Roman
Church for the purpose of accepting, suing for, exacting, defending or
administering the goods that in future happen to be offered or granted
to the Brothers or to the above mentioned Order, or come to them in
other ways, and that anyone whatever should dare, on the occasion of
any privilege whatever, to assume or perform in the name of the said
Church the administration of any goods whatever that in future
happen to come to the Brothers or to the Order, in the courts or
outside them, suing or defending, supplicating, or in any other way
whatever, unless by special permission of the Apostolic ....

Enfim, o objetivo teórico-prático da Ad conditorem canonum de João XXII era sempre de negar a validade (e, portanto, a legitimidade) da noção de "simplex usus facti", como se deduzia da Exiit. Segundo o papa, não se podia fazer um uso justo de uma coisa sem ter alguma espécie de direito sobre ela, ao menos um direito de uso; não se podia fazer um uso justo de uma coisa consumível com o uso sem ter um "dominium" (direito de propriedade sobre ela). O resultado disso foi que os Frades menores não poderiam renunciar a todos os direitos sobre as coisas, mas deveriam manter ao menos um direito de uso; como também não podiam renunciar ao direito de propriedade em relação às coisas que se consomem com o uso. As sutilezas jurídicas de João XXII implicavam na questão de renúncia ao direito de propriedade dos Frades em nível eclesiológico e eclesiástico ${ }^{318}$.

João XXII já negou de uma certa forma o paradigma de pobreza franciscana com a Ad conditorem canonum, mas a segunda bula publicada no dia 22 de novembro de 1323, a Cum inter nonnullos, em que o papa declarou herética a concepção franciscana de que Cristo nada tivesse possuído, surtiu um efeito ainda maior, porque foi negada a identidade ou razão de existência da Ordem franciscana, que estava fundamentada no princípio de não possuir nada.

\footnotetext{
${ }^{317}$ IDEM, Ibidem.

${ }^{318}$ MERLO, Grado G. Op. cit., pp. 178 e 179.
} 
No trecho abaixo da Cum inter nonnullos, João XXII condenou a ideia franciscana de que Cristo e os seus apóstolos nada possuíam, nem em particular e nem em comum, além de condenar a discussão franciscana de que Cristo e seus apóstolos, no tocante aos bens de que dispunham, não tinham nenhum direito de usá-los, regulamentá-los, emprestá-los ou trocá-los.

\begin{abstract}
Since among not a few scholarly men it often happens that there is called into doubt, whether to affirm pertinaciously, that Our Redeemer and Lord Jesus Christ and His Apostles did not have anything individually, nor even in common, is to be censured as heretical, diverse and opposite things being opined concerning it, We, desiring to put an end to this contest, after [having taken] the counsel of our brothers [the cardinals] by this perpetual edict do declare that a pertinacious assertion of this kind, when sacred scriptures, which assert in very many places that they had not a few things, expressly contradict it, and when it supposes openly that the same sacred scripture, through which certainly the articles of orthodox faith are proven in regards to the aforesaid things, contains the ferment of falsehood, and consequently, as much as regards these things, emptying all faith in them, it renders the Catholic Faith doubtful and uncertain, taking away its demonstration, is respectively to be censured erroneous and heretical. ${ }^{319}$
\end{abstract}

Como vimos, a Cum inter nonnullos não tocava nas afirmações dogmáticas que estavam na Exiit qui seminat; a decisão de João XXII era de caráter jurídico e, no fundo, se opunha ao pensamento de que a pobreza de Cristo em relação à não propriedade e ao simples uso de fato (simplex usus facti) estivesse expresso em categorias jurídicas. Evidentemente, a Ordem foi duramente golpeada durante o seu pontificado, porque todo o sistema menorita desde o movimento Franciscano da primeira geração tinha sido construído sobre o ideal de pobreza. Aliás, a base de construção da Norma do movimento franciscano sempre foi a pobreza, a humildade e a Imitatio Christi. O papa não só refutou a doutrina tradicional da pobreza de Cristo, como rebateu a provocação da circular franciscana e acirrou a disputa doutrinal entre os franciscanos e dominicanos, diminuindo a influência franciscana na cristandade.

Again to pertinaciously affirm in the preceeding [matter], that the right to use would not by any means have pertained to Our aforesaid Redeemer [and] to His Apostles for those [things], which sacred scripture testifies they had had, or that they would not have had the right to sell or given them away, or on account of these [the right] to

319 Bula "Cum inter nonnullos" de João XXII. Disponível em: <http://www.franciscanarchive.org/index2.html> Acesso em: 20 Agos. 2010. 
acquire them, which things nevertheless sacred scripture testifies that they did in regard to the aforesaid things, or supposes expressly that they could have acted thus, since such an assertion evidently would constrain that their use [of things] and their conduct, as regards the aforesaid things [were] not just, which certainly as regards the use, conduct or deeds of Our Redeemer, the Son of God, is wicked to opine, We do delcare, after [having taken] the counsel of our brothers [the cardinals], this pertinacious assertion to be deservedly censured as contrary to sacred scripture, inimical to Catholic doctrine, and heretical. $^{320}$

Por último, João XXII afirmou que Cristo e seus Apóstolos possuíam bolsa, segundo as Sagradas Escrituras e, portanto, tinham propriedades e utilizavam dinheiro. Para o papa, herético era também sustentar que eles não tiveram direito algum, mas somente o simples uso de fato. Como já mencionamos, João XXII recusou à Igreja as propriedades dos franciscanos, assim, a partir de 1323, a Igreja Romana não era mais a proprietária dos bens móveis e imóveis da Ordem Franciscana. Iniciou-se a chamada crise institucional dentro da Ordem menorita, porque o princípio básico da Regra de não ter propriedades e não possuir nada foi classificado de herético pelo papa (chefe da Cristandade latina). Consequentemente, João XXII usou a jurisprudência para diminuir a influência dos franciscanos na cristandade.

Em suma, para João XXII era herético acreditar e declarar que a pobreza evangélica implicava na ausência de qualquer forma de propriedade, pois a pobreza evangélica já não coincidia com a pobreza franciscana, ou a pobreza franciscana já não poderia ser mais a mesma, a identidade forte e característica dos Menores, que havia sido elaborada em estreita união com o papado na construção da normativa franciscana; agora, neste momento, era negada pelo papa Assim, o paradigma de pobreza franciscana foi negado.

No pontificado de João XXII, os Espirituais foram excomungados e perseguidos, a Igreja não ficou mais responsável pelas propriedades dos frades e a concepção básica de pobreza franciscana do princípio de não ter propriedade porque Cristo não tinha propriedades foi considerada herética conforme as bulas supracitadas pelo papa João XXII, acentuando a crise institucional que apresentava seus sintomas já no pontificado de Clemente V. Como vimos, as teses de João XXII eram exatamente opostas às sustentadas pelos frades da "Comunidade" no "manifesto franciscano de Perugia de 1322".

${ }^{320}$ IDEM, Ibidem. 
Novamente para rebater as críticas das bulas anteriores, em 10 de novembro de 1324 o papa João XXII publicou a bula Quia Quorumdam, dirigida àqueles que atacaram as duas bulas anteriores, provocando a reação do imperador Luís da Baviera ${ }^{321}$, que considerou o papa como herético e não a concepção de pobreza franciscana. ${ }^{322}$

Após as bulas de João XXII, a Ordem dos Frades menores não foi mais a mesma e nem voltaria a ser o que era antes, as providências do papa revelou não só uma mudança irreversível do movimento franciscano como também a negação da existência dos franciscanos na cristandade. Para finalizar, se as diversas interpretações atribuídas aos papas por meio de sutilezas jurídicas permitiram justificar o conceito de pobreza simbólica, conceito comum a todos os grupos cristãos do período, com João XXII encerrou-se a discussão. Com os predecessores, os franciscanos fizeram uma interpretação da pobreza de Cristo, porém dentro dos limites permitidos pela Igreja, o que era incomum aos outros grupos religiosos cristãos na teoria. A pobreza franciscana não seria aplicável na prática. A questão de aplicar a "difícil herança de Frei Francisco" permaneceu numa discussão teórica porque a prática representava uma ameaça à estrutura da própria Igreja, questionava-se o aparato da Santa Sé e aproximava-se dos movimentos heréticos do período. Em suma, com João XXII não apenas a concepção de pobreza teórica do movimento franciscano foi negada, mas também a sua própria existência. A partir desse período, a Ordem franciscana mergulhou numa crise institucional e não conseguiria agregar tamanha diversidade de interpretações dos frades sobre a pobreza de Cristo e do franciscanismo primitivo e a união destas pluralidades de linhas

\footnotetext{
${ }^{321}$ Luís da Baviera foi excomungado em 1324 pelo papa, por isso o Bávaro apelou para um concílio geral através da "Appellatio" de Sachsenhausen contra João XXII que foi acusado de heresia. O imperador era o "defensor, patrono e advogado" da Igreja universal e os altos escalões menoritas, foram levados a ver no império a referência político-institucional capaz de contrapor-se aos "desvios" doutrinais do papa e, portanto, de consentir a sobrevivência da identidade franciscana que a Sé apostólica havia "hereticamente" negado. Não houve ruptura imediata entre o papa e os franciscanos, mas em 1327, João XXII declarou herético o ministro geral Miguel de Cesena e o imperador coroado em Roma, na Igreja de São Pedro, seguiu defendendo a pobreza cristã e franciscana, declarando o papa como o "anticristo místico", colaborador de Satanás na obra de extinção da fé cristã. Luís da Baviera elegeu papa o Frei Pedro de Corbara, que assumiu o cargo como Nicolau V, mas depois retirou-se em setembro de 1330 e obteve o perdão de João XXII. O papa João XXII mandou prender Miguel de Cesena, Guilherme de Ockham, Buonagracia de Bérgamo, Angelo Clareno e frades que viam em Nicolau V uma referência de autenticidade franciscana, entre outros franciscanos, sob a acusação de "defensores" dos heréticos e de heresia. MERLO, Grado. Op. cit., pp. 180-183.

${ }^{322}$ FALBEL, Nachman. Os espirituais..., p. 170.
} 
ficou impossível, abrindo-se para as futuras divisões institucionais da Ordem. Enfim, os Espirituais franciscanos tiveram a sua identidade negada, não foram absorvidos na Ordem, desapareceram com prisões, condenações e perseguições. 


\section{CAPÍTULO III}

\section{Os debates internos à Norma: interpretações da Regra e do Testamento segundo dois Frades menores}

\subsection{O generalato de Frei Elias (1232-1239): o enquadramento institucional}

Desde o princípio da construção da Regra no movimento Franciscano houve duas alternativas ou "leituras" da pobreza normativa pelos frades como apontam os historiadores ${ }^{323}$. Por um lado, um grupo escolheu aceitar as inevitáveis mudanças advindas da institucionalização da fraternitas e de enquadramento aos cânones eclesiásticos. Por outro, sempre houve o grupo dos "resistentes" a essa institucionalização ou interferência da Cúria romana, geralmente identificada pela Observância da Regra e em combate ao relaxamento da pobreza normativa, colocando o modo de vida de Francisco e dos primeiros companheiros como o modelo a ser seguido na prática. Mas como se formaram esses dois grupos distintos na Ordem? No início havia alguns pontos discordantes que depois de cem anos de franciscanismo tiveram o seu ápice a partir do Concílio de Vienne em 1312. Para entender melhor o surgimento dos dois seguimentos na Ordem Franciscana, partiremos neste capítulo para o generalato de Frei Elias (1232-1239), onde identificamos 0 início das tensões e controvérsias em torno da pobreza normativa.

Toda fonte, franciscana ou não, italiana ou estrangeira, coloca o companheiro de Francisco, Elias de Cortona, o segundo ministro geral da Ordem depois do fundador, como pedra angular e figura trágica por excelência $^{324}$. Ao generalato de Frei Elias são atribuídos os problemas da transformação da Ordem franciscana, sobretudo da fraternitas laical em uma Ordem religiosa mais tradicional, mais próxima ao movimento Dominicano, com uma marca clerical mais acentuada. Assim, segundo as hagiografias de

${ }^{323}$ BURR, David. The Spiritual Franciscans. From protest to Persecution in the century after Saint Francis. Pennsylvania: The Pennsylvania State University Press, 2001, p. 11.

${ }^{324}$ BARONE, Giulia. Frate Elia: suggestioni da una riletura. In: I compagni di Francesco e la prima generazione minoritica. Atti del XIX Convegno internazionale, Assisi, 17-19 ottobre 1991. Espoleto: Centro Italiano di studi sull'alto medioevo, 1992, pp. 61 e 62. 
Boaventura e Salimbene, Elias de Cortona foi acusado de trair a idealização da pobreza de São Francisco, quando exerceu o cargo de ministro geral. Ele introduziu inovações que levaram ao início das tensões de grupos que mais tarde iriam se desenvolver dentro da Ordem transformando-se em duas facções $^{325}$. No entanto, para melhor esclarecer o enquadramento institucional da Ordem Franciscana e o processo marcado por conflitos internos faz-se necessária a desconstrução da imagem negativa dada a Frei Elias, porque as hagiografias franciscanas foram construídas de acordo com os partidarismos dos dois grupos envolvidos na questão da interpretação e aplicabilidade da pobreza da Norma de 1223.

Provavelmente Elias era originário de Assis, onde nasceu em 1180. Foi contemporâneo de Francisco, de origem bastante humilde. Dos seus primeiros anos na Ordem nada se sabe, mas em 1217 já era ministro provincial da Terra Santa. Depois do insucesso da experiência no Oriente, Francisco renunciou a ser o guia do movimento Franciscano, exatamente entre a composição da Regula non bullata e da Regula bullata. Depois de um breve período, Pedro Caetano foi nomeado ministro geral, mas faleceu e Elias assumiu a responsabilidade da Ordem, justamente nos últimos anos em que a Ordem recebeu um reconhecimento oficial da Igreja com uma Regra definitiva, organizando-se em províncias. Após a morte de Francisco, Elias não é confirmado no cargo de ministro geral. O Capítulo geral de Assis de 1227 elegeu João Parente (1227-1232), de origem centro-italiana e de boa formação jurídica, ministro geral e não Frei Elias, aquele que o próprio Francisco havia posto à frente da Ordem. João Parente tinha sido ministro provincial da Espanha desde 1219, quando sucedeu Bernardo de Quintavalle. Foi um homem de cultura que incentivava os estudos na Ordem, embora fosse simples no seu estilo de vida. João Parente organizou a liturgia do movimento Franciscano, entre outras medidas organizativas importantes para a Ordem.

A partir da primavera de 1228, Gregório IX havia destinado a Frei Elias uma tarefa bastante importante, a construção do santuário de São Francisco de Assis que albergaria o corpo do Santo juntamente com outras relíquias. A canonização de São Francisco representou um ponto chave para entendermos

${ }^{325}$ FALBEL, Nachman. Os espirituais..., p. 31. 
o processo de conflitos internos na Ordem. A partir deste momento, o limite da aplicabilidade da pobreza começava a ser delineado pelo processo de canonização. Qual o tipo de representação de pobreza seria estabelecido e determinado pela Cúria Romana? Com a canonização iniciava-se uma nova etapa de institucionalização juntamente com uma cristalização de um tipo de santidade que queria se propagar de Francisco para toda a cristandade, um modelo idealizado pela Igreja e pela cúpula dos frades intelectuais.

Por isso, a transladação das relíquias de São Francisco para um novo edifício sagrado foi uma assunto de grande importância do Capítulo de Pentecostes de 1230. No entanto, os fatos inesperados dos acontecimentos durante o percurso de transladação do corpo do Santo marcado para o dia 25 de maio de 1230 deixaram emergir as tensões internas do movimento, quando não as divisões conflitantes, que perpassaram naquele momento à Ordem e que transpareceram no que deveria glorificar a nova formação religiosa, nascida de um "santo assisiense" que a cidade de Assis necessitava para consolidar a sua independência em relação à Perugia e Espoleto, o santuário então representou o lugar materialmente estável de celebração que estava sendo inaugurado com solenidade, e tal inauguração precisava ter um bom desfecho.

Segundo as hagiografias da Ordem franciscana dos séculos XIII e XIV à Frei Elias foram atribuídas as ações de grave perturbação na transladação das relíquias de Francisco, o que representaria um ponto negativo para a canonização. Elias teria adiantado a data marcada, mas, segundo os historiadores italianos atuais, essa informação seria falsa, fruto da criatividade a posteriori que foi construída depois da deposição do próprio Elias em 1239 e não no momento da transladação de fato. Prova disso, segundo Merlo ${ }^{326}$, seria a bula Speravimus hactenus de Gregório IX endereçada aos bispos de Perugia e de Espoleto. Não era uma simples carta no sentido institucional, mas o verdadeiro sentido estava implícito no projeto de inserir uma popularidade imediata à santidade de Francisco e conservar a sua memória dentro de um determinado modelo. $\mathrm{Na}$ carta papal ficou claro que os Frades menores dependiam da vontade e dos projetos do papa, que, inclusive, a pedido do

${ }^{326}$ MERLO, Grado G. Op. cit., p. 99. 
Capítulo geral de 1230, havia redigido a Quo eloganti, a primeira exegese papal $^{327}$ sobre a Regra bulada e o Testamento de Frei Francisco. Na bula Speravimus hactenus, o papa condenou os cidadãos de Assis que, ávidos por relíquias, teriam desfigurado o corpo do "santo" se o cortejo do translado fosse inteiramente conhecido por todos; assim, ficava evidente que os cidadãos de Assis ameaçavam os interesses e ofícios eclesiásticos durante a transladação (translatio) das relíquias e o papa isentou os Menores de qualquer acusação ou suspeita em relação ao episódio. Desta forma, a bula representou um procedimento normativo e preventivo, o papa declarou que os privilégios garantidos à Basílica seriam anulados e novamente estariam sujeitos à jurisdição episcopal. Na verdade, esta atitude de Gregório IX revelou mais uma das medidas da Cúria Romana que tentava por vários meios enquadrar 0 movimento Franciscano nos moldes das demais Ordens religiosas, dar uma direcionada à institucionalização iniciada com a escrita da Regra não bulada de 1221 e estabelecer um tipo de pobreza franciscana que automaticamente excluía as outras representações de pobreza voluntária que estavam à margem da institucionalidade estabelecida.

Para Giulia Barone ${ }^{328}$, provavelmente uma parte da Comunidade havia dado a frei Elias um limite. É certo que muitos dos fiéis, frades de Assis e o próprio ministro geral se sentiram de algum modo fraudados por não terem podido participar totalmente da cerimônia e a responsabilidade veio, mais adiante, a recair sobre Elias. Mas, poderiamos sublinhar que de acordo com a bula Speravimus hactenus, que não menciona nenhuma vez o nome de Elias, nem a sua atividade de construção da Basílica pareceu ter sofrido alguma interrupção devido ao infeliz episódio da transladação. Como nos aponta Giulia Barone, dois anos depois, ele viria a ser eleito ministro geral, cargo que exerceu até 1239, o que seria uma prova da construção de um discurso negativo feito a posteriori.

Conforme Grado Merlo ${ }^{329}$, a Ordem franciscana continuava a ter muitas frades que, se por um lado, representavam uma riqueza, por outro geravam tensões, quando não divergências, difíceis de conciliar no governo e

\footnotetext{
${ }^{327}$ Em relação à Quo elongati ver o capítulo dois desta dissertação de Mestrado.

328 BARONE, Giulia. Op. cit., p. 67.

${ }^{329}$ MERLO, Grado G. Op. cit., pp.100 e 101.
} 
na base do movimento. Exemplo disso foi a eleição de Frei Elias, ocorrida em 1232, em substituição a João Parente. Assim, os anos de generalato de Frei Elias não são de fácil reconstituição devido ao modelo negativo formulado pelos "partidarismos hagiográficos", pois as fontes disponíveis são bastante tendenciosas por sua notável destituição em 1239, resultado de um acordo entre o papa Gregório IX e os frades expoentes das províncias transalpinas que tinham por objetivo acabar com um ministro geral demasiado embaraçoso para eles, por ser ligado a um franciscanismo que não era o dos frades magistri e pouco comprometido com o campo pastoral. Por exemplo, na crônica bastante condicionada de Frei Salimbene nota-se que Frei Elias é descrito como um indivíduo fascinante, áspero e autoritário, que tinha boas relações tanto com Gregório IX, quanto com Frederico II do Sacro Império Romano Germânico. Além disso, o comportamento de Elias é descrito como de uma certa extravagância e se destacava por uma acentuada "rusticitas" ou "má educação", que contrastava com a "curialitas" própria do modelo aristocrático que Frei Salimbene julgava ser o valor respectivo da vida religiosa e dos religiosos. Assim, o anti-modelo formulado de Elias seria composto de treze "defeitos" enquanto exerceu o cargo de ministro geral, tanto no plano pessoal como em relação ao generalato que exercia. Primeiramente, ele teria favorecido excessivamente os frades leigos da Ordem durante 0 seu generalato, o que representava para Frei Salimbene uma "inutilidade", visto que eram "indignos" de exercer os "officia Ordinis" ${ }^{330}$. Na verdade, Frei Salimbene era um opositor ao elemento laico na Ordem porque não representaria a pobreza almejada pelos frades da cúpula franciscana. Para Giulia Barone, Elias afirmava que agia segundo a Regra, porém, faltava uma estrutura à Ordem, que tinha uma Regra mas não tinha uma Constituição, como os Dominicanos, os Beneditinos etc, o que contribuiu para a turbulência dos anos de Elias no seu ministério. ${ }^{331}$ A redação de uma constituição não era uma tarefa fácil e a exigência talvez fosse demasiada para Elias.

Antes de mais nada, a oposição a Frei Elias se manifestou entre os frades zelantes da Regra, por exemplo, com Frei Cesário de Espira e seus seguidores (rebeldes denominados cesarenos), além do núcleo forte nos

\footnotetext{
${ }^{330}$ MERLO, Grado. G. Op. cit., pp. 101 e 102.

${ }^{331}$ BARONE, Giulia. Op. cit., p. 69.
} 
ministros ultramontanos, que o criticavam pelo fato de nunca ter convocado um Capítulo geral, limitando-se a reunir em Capítulos "particulares" somente os ministros cismontanos, acusação não confirmada pelas fontes contemporâneas do generalato. Enfim, para Merlo, a deposição de Elias foi uma combinação articulada entre os ministros provinciais ultramontanos e Gregório IX no Capítulo de Roma de 1239, no qual, em clima bastante tenso, com conflitos verbais acalorados entre Frei Elias e seus seguidores e o grupo de opositores, que tinham em Frei Haimo de Faversham o principal expoente, que foi eleito ministro geral após a morte de Frei Alberto de Pisa, falecido após a eleição. Logo após a eleição do clérigo Frei Haimo de Faversham iniciou-se um processo de sacerdotalização definitiva da Ordem em 1240.

No Capítulo de Roma de 1239, as províncias franciscanas haviam sido limitadas ao número de trinta e duas, das quais dezesseis eram "ultra montes" e dezesseis "citra". Esta subdivisão atendia à exigência estratégica dos seguidores de Haimo de Faversham de não multiplicar as "voces" com direito a participar ativamente do Capítulo geral destinado à eleição do ministro geral. Com esses dados em vista, afirmamos mais uma vez que se tratou de interessses de grupos a imagem negativa dada à Elias. Neste mesmo ano foram promulgadas as "Constituições gerais" com o objetivo de "conservação" da Regra e de um "governo uniforme" da Ordem segundo Frei Salimbene. Um determinado plano de interpretação da pobreza estava traçado. Para além da intangibilidade da Regra, colocou-se a necessidade de elaborar normas constitucionais que respondessem à mudança das condições e das situações em que os frades viriam a se encontrar. Para o grupo opositor à Elias, seu generalato foi turbulento porque teria demonstrado a necessidade de uma "ordinis reformatio" e as constituições de 1239 foram muito eficazes, já que vinte anos depois no generalato de Boaventura, elas foram somente "ordenadas" com a introdução de poucos acréscimos. A partir deste momento, a Ordem recebia uma estrutura fortemente sacerdotal e monástica, conservando a inspiração pauperística que excluiria os grupos que não se encaixassem neste limite. Além disso, abriu-se uma fresta através da qual 
passaram infinitas discussões e contínuos conflitos sobre a aplicabilidade da pobreza normativa, que se prolongaram pelos oitenta anos seguintes. ${ }^{332}$

Como vimos, a deposição de Frei Elias recebeu diferentes significados, pois dependia muito do grupo de frades. Em linha geral, três questões são pertinentes para compreendermos a representação deste frade na Ordem. A primeira é a adesão de Elias ao imperador Frederico II logo após a sua deposição; a segunda, o papel desempenhado por Elias no favorecimento ou refreamento do processo de clericalização da Ordem; e a terceira, a benção de Elias dada por Francisco no seu leito de morte.

Em primeiro lugar, Frei Elias seguiu um caminho próprio, que logo entrou em conflito com o papado, isso significando que a Igreja ajudou na colaboração de uma imagem negativa. Mesmo após os pedidos de Frei Alberto de Pisa, então ministro geral, Elias continuou a visitar o imperador e o papa o excomungou. Talvez com alguns frades de sua família, Frei Elias transferiu-se para perto de Frederico II, de quem era "amigo" há muito tempo e que havia expresso de forma oficial sua contrariedade pela deposição de Frei Elias. Os laços entre Elias e o imperador foram reforçados no inconciliável conflito entre papado e império, indicando de forma indireta que a Ordem franciscana havia atingido os mais altos níveis da sociedade e que, para todos os efeitos, já pertencia à esfera do poder. Deste modo, a permanência junto ao imperador revelou uma colaboração de Frei Elias na política imperial, com relativa ruptura com o papado e com a Ordem durante cinco anos. Em 1245, Frei Elias retirouse para a Cella de Cortona e ocupou-se da construção de uma igreja dedicada a São Francisco na cidade mais próxima. Por diversas vezes, rejeitou as propostas de reconciliação do ministro geral João de Parma, eleito em 1247. Enfim, provavelmente antes de sua morte, ocorrida em abril de 1253, Frei Elias tenha se reconciliado com a Cúria romana e a Ordem franciscana. ${ }^{333}$

Em segundo lugar, conforme a crônica tendenciosa de Frei Salimbene, Frei Elias teria recebido um número elevado de leigos nos conventos e os havia nomeado para os cargos de "guardiães, custódios e ministros, quando na Ordem havia grande número de bons clérigos", com o objetivo de aumentar o próprio poder e de adquirir riquezas. Entendemos que para Salimbene, era

\footnotetext{
${ }^{332}$ MERLO, Grado G. Op. cit., pp. 103 e 104.

${ }^{333}$ IDEM, Ibidem, pp. 105 e 106.
} 
inconcebível que no tempo de Frei Elias os "leigos" tivessem mais importância do que os "sacerdotes" ou a mesma paridade. Os exemplos citados na crônica evidenciavam situações absurdas como a história de um convento em que os "leigos" queriam que o "sacerdote" trabalhasse na cozinha, invertendo a hierarquia local. A desconstrução negativa de frei Elias posta por esta e outras hagiografias se faz necessário.

Enfim, para Salimbene, as ações de Elias conflitavam com o desenvolvimento da Ordem, que quase fechava totalmente o acesso aos leigos segundo a Constituição de 1239. Outro "defeito grave" de Elias era almejar que o seu cargo de ministro geral fosse vitalício, o que dificilmente se concretizaria porque, como vimos, as eleições para ministro geral se davam em Capítulos gerais regulamentados pela Regra de 1223. Outros atributos negativos dados à Elias, como despótico e ávido para com os ministros provinciais, não parecem ser dignos de veracidade. Portanto, conclui-se que segundo a hagiografia de Salimbene era difícil viver sob o generalato de Frei Elias, pois este havia gerado tensões e divisões nos ministros provinciais, o que não nos parece ser verdade, apenas uma construção negativa dada por interesses políticos de um grupo. Assim, o equilíbrio que existia entre o centro-periferia das províncias franciscanas teria sido rompido e Elias teria favorecido o processo de aceleração da clericalização da Ordem com suas atitudes desfavoráveis ao clero franciscano, fato bastante questionável.

Em terceiro lugar, quando Elias estava na posição de vigário geral da Ordem, quando anunciou a morte de São Francisco aos frades e ao mundo, foi ele quem dispôs do corpo do santo para enterrá-lo, além de ter recebido a benção de Francisco no lugar de Frei Bernardo (o primogênito da fraternitas). $\mathrm{Na}$ carta em que anunciou a morte do Frei Francisco, Elias elaborou um texto de uma forma cuidadosa e articulada, visando a alguns objetivos práticos como o de solidificar a memória de Francisco. Enfatizou com bastante descrição a estigmata do Pobre de Assis com a intenção de difundir a santidade de São Francisco para facilitar a canonização e a construção da basílica de acordo com os planos de Gregório IX, entre outras atitudes que não consideramos como graves. A proposta estava de acordo com a canonização dada pela Igreja, mas Elias desagradava em outros aspectos à cúpula da Cúria romana e da Ordem como mencionamos. 
O contra-modelo de Elias é Frei Leão, visto com positividade e exemplo a ser seguido. Segundo a historiografia atual, a Ordem franciscana construiu o modelo (Frei Leão) para contrapor ao antimodelo (Frei Elias), que depois foi usado pelos Espirituais franciscanos da Úmbria no século XIV. São modelos que precisam ser desconstruídos se quisermos compreender melhor os processos de conflitos e representações de pobreza que ficaram à margem da institucionalização. A filiação partidária e historiográfica precisa ser desarticulada destes dois modelos de frades se quisermos entender as discussões em torno da pobreza normativa que se transformaram numa contenda jurídica da aplicabilidade da Regra de 1223.

Segundo Celano, um dos primeiros companheiros de Francisco foi Bernardo de Quintavalle, um rico nobre de Assis, e Pedro Caetani, um clérigo de São Rufino que teriam, os dois, iniciado a fraternitas aproximadamente entre 9 ou 14 de abril de $1208^{334}$. A escolha da pobreza pregada em palavras simples, mas sobretudo caracterizada por ações, tinha-os rapidamente induzido a seguir o exemplo de Francisco. É impossível optar no plano factual por uma das duas tradições da origem da fraternitas franciscana; elas são de caráter folclórico, uma é a abertura tríplice do missal, conhecido popularmente por sortes apostolorum, a outra seria a leitura do Evangelho de São Mateus durante uma missa. A veracidade da história de uma ou outra tradição ou de ambas parece sustentar-se sem nenhuma dificuldade para os historiadores.

A fraternitas iniciou-se com a entrada dos primeiros companheiros que partiam de dois em dois para a pregação itinerante. Depois de Bernardo e Pedro, entraram Sabbatino, Morico e João Capela. Divididos em dois, sairam "per mundum" formando três grupos de dois até chegarem ao número de doze, conseguindo a aprovação oral de Inocêncio III e formando a primeira geração menorita. Sobre a vida destes primeiros integrantes pouco se sabe, principalmente da vida de Leão, que se agregou ao grupo rapidamente e logo tornou-se um companheiro inseparável de Francisco e o frade modelo para um determinado grupo existente na Ordem.

\footnotetext{
${ }^{334}$ MENESTÒ, Enrico. Leone e i compagni di Assisi. In: I compagni di Francesco e la prima generazione minoritica. Atti del XIX Convegno internazionale, Assisi, 17-19 ottobre 1991. Espoleto: Centro Italiano di studi sull'alto medioevo, 1992, p. 35.
} 
Leão ficou conhecido por "pecorella di Dio", o confidente do mestre fundador e seu herdeiro no fervor e nos ideais, uniu-se ao grupo após a aprovação oral dada em 1210. Entre os companheiros de segunda hora, Leão transformou-se num dos mais próximos de Francisco, sendo o seu confessor e secretário inseparável. Suficientemente culto, conhecedor da língua latina, é certo que Leão foi o principal e fiel companheiro de Francisco segundo as Cartas e as hagiografias. Leão estava sempre presente, inclusive junto ao leito de morte de Frei Francisco e depois ao de Clara. Enfim, os modelos sempre precisam ser desconstruidos se almejamos entender as diferentes linhas de pobreza advindas da interpretação da Regra bulada e do Testamento.

Segundo a historiografia italiana atual, podemos atribuir positividade à Leão devido a uma série de hagiografias, entre elas a Compilatio Assisiensis, a Legenda trium sociorum, a Legenda do Anônimo perusino e talvez o Speculum perfectionis. Assim Frei Leão teria sido um dos principais protagonistas e artifíces da memória histórica de Francisco. É muito provável que alguns escritos foram feitos após a compilação da biografia bonaventuriana e quando os conflitos internos da Ordem franciscana já estavam bastante aflorados. Porém, o mais importante não é a narração dos episódios, mas a transmissão da logia de Francisco, que era apresentado num contexto expositivo, mas geralmente muito conciso, restrito ao mínimo necessário, com a função de sistematizar as palavras do Santo num Sitz im Leben segundo Enrico Menestò ${ }^{335}$. Concordamos com a opinião deste historiador, se pensarmos no fato de que a Igreja romana pretendia propagar um modelo de santidade de Francisco que foi consagrado com a sua canonização; esse modelo continua a ser cultivado, e os que não contribuiam para a difusão da santidade formulada deveriam se adequar às prescrições ou se afastar da Ordem.

Frei Leão morreu em 13 de novembro de 1271. Neste momento, a Ordem Franciscana tinha uma divisão interna mais acentuada entre o grupo da pobreza inserida no mundo eclesiástico e o grupo da pobreza de uma condição material e ascética. A pobreza de Francisco não foi uma coisa, não era uma condição institucionável, era uma condição mística, de estado de espírito e de ideal. Desta forma, era uma condição histórica e não de uma defesa em

${ }^{335}$ MENESTÒ, Enrico. Op. cit., p. 54. 
exagero da pobreza. Talvez Leão tenha defendido uma pobreza histórica da mensagem de Francisco, a premissa da mesma perfeição, antes da prerrogativa principal por ser perfeito, não por aquela pobreza que conduzia à "vitória" mística. Assim, o profundo significado da pobreza franciscana estaria na imitação de Cristo, pobre e sofrido que se fez pobre por nós. Pobreza que foi sintetizada e enquadrada na Regra de 1223.

Além do mais, Leão teria sido o frade que rompeu o vaso que seria usado para recolher dinheiro para a construção da Basílica de Assis. Por seu ato, Leão teria sido perseguido pelo ministro geral Elias, por isso foi obrigado a fugir. Um dos "graves defeitos" de Elias teria sido esse: ele arrecadou uma quantia exagerada de dinheiro para a construção da Basílica da Igreja que era caput e mater de toda a Ordem. Enfim, esses dois modelos representariam dois caminhos interpretativos da pobreza da Regra bulada; a questão que vinha por trás era como interpretar e aplicar a "lex fundamentalis" nos conventos. A "leitura" da pobreza por cada um desses grupos revela-nos que é necessária a desarticulação desses dois modelos de frades, nem perto de Leão e nem longe de Elias. A questão é mais complexa do que o generalato de Elias e algumas medidas por ele tomada.

Para Merlo ${ }^{336}$, o generalato de Frei Haimo de Faversham caracterizouse por uma fase de incerteza, com intervenções de decidida clericalização, enquanto o de Frei Alberto de Pisa, o primeiro ministro geral sacerdote, abriuse para uma nova possibilidade de sancionar a definitiva sacerdotalização da Ordem. Mas a questão por trás dessas medidas dos vigários da Ordem tem como pano de fundo a disputa pela interpretação da pobreza normativa entre os grupos e a interferência constante da Santa Sé, que a cada momento tinha uma função a dar para a Ordem franciscana. Em 1241, Gregório IX iniciou o processo de inserção dos Menores nos quadros das hierarquias episcopais, decisão seguida por Inocêncio IV, multiplicando os Frades menores nas cátedras arquiepiscopais e episcopais. O que fica claro é que a Ordem franciscana caminhava de acordo com os planos hegemônicos do papado, como encargos pastorais de orientação, ensino, educação e formação dos fiéis. Inclusive o papa elegeu um Frade menor para o cargo de arcebispo de Milão, o

${ }^{336}$ MERLO, Grado G. Op. cit., p. 107-110. 
que causou divergências e discussões internas na Ordem. Desta forma, como nos assinala Merlo, as metamorfoses do franciscanismo, mesmo promovidas e sancionadas pela cúpula da catolicidade e da Ordem, não foram aceitas de modo acrítico por todos os frades, embora no fim se impusessem de forma irreversível e contribuiram para as divisões da Ordem que cresciam, principalmente com as Expositio da Regra mediante técnicas da escolástica com análise e interpretação que poderiam levar a interpretações bem distantes da intentio de São Francisco. Aliás, essa intentio ninguém sabia ao certo qual era, por isso a disputatio entre os frades para tentar fazer e chegar mais perto do franciscanismo primitivo. O problema é que após a canonização de Francisco e a clericalização da Ordem, dificilmente algum frade saberia expor a Regra da maneira mais próxima aos primeiros tempos, porque um modelo difundido de São Francisco direcionava para uma interpretação tendenciosa, além do que a Regra já era uma normativa influenciada por clérigos da alta cúpula da Igreja e da Ordem, o que não mudava o espiríto do movimento, mas direcionava-o para outros caminhos.

Em suma, fica evidente que, na figura de Leão mais que em outros companheiros de Francisco, apareceu uma caracterização, de um lado pela amizade fraterna com Francisco, e de outro por um contraste com Elias; assim, Leão seria o oposto de Frei Elias, que foi um antimodelo de frade para toda a Ordem, entre outros motivos por haver arrecadado uma alta soma em dinheiro para construir a Basílica de Assis, violando a Regra, e também porque pretendia controlar os ministros provinciais por meio dos visitatori, descumprindo a Regra de 1223 que determina a reunião dos ministros em Capítulos gerais a cada dois anos. Entretanto, sabemos que os conflitos e debates acerca da pobreza franciscana iam muito além desses dois modelos de frades.

Provavelmente o contraste entre Frei Francisco e Frei Elias fosse insustentável para Leão, não apenas pela distância entre os dois, mas também porque o fenômeno da inserção do movimento Franciscano na estrutura eclesiástica fosse insignificante para ele, como talvez fosse para Francisco, que não estava preocupado com os rumos da Ordem, mas com o seu ideal de pobreza. Leão foi certamente um grande personagem, o herói da epopeia franciscana, o símbolo vivo da revolta dos Espirituais no século XIV e hoje da 
historiografia de esquerda combativa. Já Elias cristalizou-se como o início de todo o mal, segundo Angelo Clareno, o início da sacerdotalização da Ordem, representante de uma historiografia mais conservadora. Novamente, colocamos que é preciso ir além desses dois modelos para entendermos as divisões internas da Ordem e os conflitos tensos nela imbricados devido à problemática questão da interpretação da pobreza normativa e como esta deveria ser interpretada. Para ir além destes dois modelos, partiremos agora para a análise do escrito de Boaventura e, mais adiante, da Expositio de Angelo Clareno, dois frades significativos para a Ordem.

\subsection{A questão da pobreza na obra Expositio super Regulam Fratrum Minorum da década de 1260 de Boaventura de Bagnoregio (1221-1274)}

Como bem nos assinala Malcolm Lambert sobre a pobreza da fraternitas, para Francisco a natureza da pobreza de Cristo foi uma realidade pressuposta e o mesmo se pode dizer dos seus primeiros companheiros. A necessidade prática daquela vida nos anos iniciais do desenvolvimento era tão urgente que eles não tiveram nem a vontade nem a possibilidade de aprofundar as bases teóricas da doutrina da pobreza absoluta. Seja para Francisco, seja para os primeiros franciscanos, a doutrina encontrou expressões em termos mais devocionais do que acadêmicos ${ }^{337}$. A esta pobreza da fraternitas chamamos de ideal ou estado de espírito num grau elevado de abstração numa época emergente em que a burguesia dominava o ambiente citadino, oriundo dela e renegado por esta mesma burguesia.

Indubitavelmente, a pobreza da primeira fase do movimento Franciscano foi antes um estado de espírito do que uma norma regulamentada. Sendo assim, podemos aferir que em grande parte as metamorfoses ${ }^{338}$ do movimento Franciscano dependiam das interpretações da Regra franciscana por frades de cultura mais alta ou por frades "magistr", que, embora desejassem ser fiéis à proposta religiosa de São Francisco, só podiam interpretá-la à luz da própria cultura escolástica, totalmente voltada para a precisão conceitual de todas as palavras que, como tais, transmitiam valores e

\footnotetext{
${ }^{337}$ LAMBERT, Malcolm D. Op. cit., p. 123.

${ }^{338}$ MERLO, Grado G. Op. cit., pp. 110 e 111.
} 
uma determinada "leitura", mas não podiam ser aceitas sem se perguntar a fundo a correspondência entre significante e significado ou significados. Exemplo disso foi o texto da Expositio quatuor magistrorum super Regulam fratrum Minorum, obra dos mestres do Studium parisiense Alexandre de Hales, João de la Rochelle, Roberto de la Bassé, Otão Rigaldi e Godofredo de Brie. Os frades parisienses precisavam mostrar que o esforço de compreensão da "dubitalia Regule" provinha da "ex ipsa littera" da Regra e não com base no "sensus". Desta maneira, a auctoritates entrava de fora como elemento constitutivo da Regra, e embora fosse apresentada como contribuições à "expositio" da Quo elongati de 1230, ela abria novos caminhos interpretativos da Regra franciscana. E assim a pobreza franciscana começava a repartir-se em vários caminhos.

Antes de mais nada, a intenção de ler a Regra "de forma simples e pura", procurando ser fiel à "letra" do texto, não era mais possível porque entre os anos de 1223 a 1241, as questões e contextos aos quais deveria responder haviam mudado de forma irreversível os rumos da Ordem. Desse modo, as palavras de Frei Francisco, embora aparentemente simples, submetidas a um exame semântico-jurídico tornavam-se complicadas conforme nos aponta Merlo ${ }^{339}$. Portanto, o que significava "apropriar" ou poder comprar, vender, contrair um empréstimo, alugar, penhorar, doar, emprestar, de uma geração menorita para outra mudava e as interpretações dependiam de uma forma de raciocinar muito distante da "simplicidade" do discurso de Frei Francisco exposto na Regulae e no seu Testamentum. As reflexões dos "mestres" evidenciavam uma grande distância, objetiva e subjetiva, entre o viver e o pensar a Imitatio Christi, distância que se tornava sempre maior na medida em que o pensar a pobreza se tornava mais importante do que o viver a pobreza, dependendo tanto dos desenvolvimentos de agentes internos da Ordem, quanto das reações dos agentes externos ao movimento Franciscano.

Dentro deste contexto de incertezas é que surge um dos maiores "sintetizadores" e teóricos da Ordem franciscana, Frei Boaventura. Ele nasceu em Bagnoregio, na Toscana, em 1221 (ano da Regra não bulada), destacouse como estudante na Universidade de Paris, sendo discípulo de Alexandre de

${ }^{339}$ IDEM, Ibidem. 
Hales, um dos quatro mestres expositores da Regra franciscana, que teria influenciado a sua entrada na Ordem Franciscana por volta de 1243. De 1243 a 1248, Boaventura completou os estudos teológicos, conseguindo o título de bacharel, e tornou-se catedrático em 1253, envolvido na primeira grande ofensiva dos mestres seculares do Studium de Paris contra os mestres "mendicantes". No ano de 1257, no Capítulo geral de Parma, o ministro geral João de Parma renunciou ao cargo em meio a uma grave crise provocada pelo fato de ser simpatizante dos frades joaquimitas, seguidores do abade calabrês Joaquim de Fiore (c.1132-1202) ${ }^{340}$. Na presença do papa Alexandre IV (12541261), João de Parma indicou, no dia 2 de fevereiro de 1257, para sucedê-lo, Boaventura, que tinha então trinta e seis anos, julgando-o o "melhor" entre todos os frades que conhecia ${ }^{341}$.

Logo após a sua eleição como ministro geral ele enviou uma Carta a todos os ministros e guardiães da Ordem afim de colocar fim à crise institucional, tentou reconciliar-se com a oposição, estabelecendo como objetivo de governo: defender a Ordem contra os inimigos externos, manter e completar a evolução da Ordem dando-lhe uma organização definitiva, e buscar observância da Regra comum a todas as províncias.

Falbel descreve Boaventura como um homem contemporizador com 0 mundo, que procurava antes conciliar a Ordem com as transformações havidas do que levá-la a uma modificação radical. Aceitou o usus pauper de maneira moderada, mas não foi ao ponto de exigir a extrema penúria de São Francisco e seus primeiros companheiros. P. Gratien ${ }^{342}$ define Frei Boaventura como um conservador que aceitava a Ordem tal como ela era, não queria inovar. Foi um frade representante da Comunidade, isto é, da maioria dos frades: foi um

\footnotetext{
${ }^{340}$ Nascido em Celico, na Calábria, Joaquim de Fiore (c. 1135-1202) foi um abade cisterciense e filósofo místico, defensor do milenarismo e do advento da idade do Espírito Santo. Seu pensamento se resume a uma interpretação apocalíptica e escatológica da História, profético e milenarista, pareceu ter incendiado as mentes no seu tempo, fornecendo elementos espirituais esperados por heréticos, místicos e apocalípticos. A sua concepção de História era a da Trindade num esquema interpretativo teológico na qual haveria três idades: a do Pai, a do Filho e a do Espírito Santo. Os franciscanos foram os principais difusores do joaquimismo na Idade Média. Sendo assim, viam São Francisco como um prelúdio de uma nova era. Ver FALBEL, Nachman. Heresias medievais. São Paulo: Perspectiva, 1976, pp. 72 e 73. Segundo Gordon Leff, o "franciscanismo joaquimita" foi apenas uma das várias formas que tomaram as doutrinas do abade calabrês Joaquim de Fiore nas mãos de seus seguidores. LEFF, Gordon. Heresy in the Later Middle Ages: The Relation of Heterodoxy to Dissent c.1250 - c.1450. Machester/Nova York: Manchester University Press/Barnes \& Nobles, 1967, p. 176.

${ }^{341}$ MERLO, Grado G. Op. cit., p. 117.

${ }^{342}$ FALBEL, N. Os espirituais..., p. 100.
} 
"apologista da evolução franciscana e moderador da observância regular". Segundo Merlo, durante todo o generalato de Boaventura de Bagnoregio, as "metamorfoses" do franciscanismo e as evoluções da Ordem franciscana passaram por uma complexa obra do geral para o particular realinhamento teórico e prático, sem eliminar os desvios existentes entre ideal "franciscano" e integração eclesiástico-social ${ }^{343}$. Já para David Burr ${ }^{344}$, o generalato de Boaventura primava pela noção da via media; no caso da pobreza evangélica consistiu na renúncia à propriedade e a posse das coisas, mas manteve o uso e limitou esse uso sem rejeitar a necessidade; em outras palavras, defendeu a renúncia a todas as coisas, mas não o usus que é necessário para os estudos e a atividade pastoral. Em resumo, Boaventura insere-se entre os moderados da Ordem.

No tocante à Regra, Falbel ${ }^{345}$ assinala que Boaventura buscava ser fiel à Regula e a interpretava de modo que não a contradizesse; por outro lado, justificava uma Ordem assentada sobre certas facilidades ou comodidades e o usufruto das coisas, mas não a propriedade ou domínio. O que é confirmado por Boaventura na carta Tribus quaestionibus, na qual afirma que a Regra não negava o usus das coisas e sim a appropriatio, fazendo referência à Quo Elongati, de Gregório IX, quando reafirma numa passagem que nada do que é usufruído pelos frades pode ser vendido ou alienado, a não ser pelo cardeal que for governador da Ordem, o ministro geral ou os ministros provinciais, de acordo com a obediência.

No Capítulo de Narbonne de 1260, presidido por Boaventura, tivemos a aprovação de doze capítulos ou rubricas, que passaram a ser a legislação mais ordenada e sistematizada até aquele momento; em resumo tratou-se da admissão dos noviços, do hábito, da observância, da prática da penitência, das relações com o mundo laico, da ocupação dos frades, das disciplinas, das visitações nas províncias, da eleição dos ministros, do Capítulo provincial, do Capítulo geral e dos sufrágios aos frades defuntos. A pobreza foi ratificada sob o ponto de vista intelectual, uma interpretação da pobreza da Regra que se distanciava da observância da pobreza das origens. Boaventura ordenou desde

\footnotetext{
${ }^{343}$ MERLO, Grado G. Op. cit., p. 98.

${ }^{344}$ BURR, David. Op. cit., p. 36.

${ }^{345}$ FALBEL, Nachman. Op.cit., pp. 100 e 101.
} 
a proibição de lidar com o dinheiro até a austeridade na construção de conventos, e impediu qualquer possessão por parte dos frades. Enfim, Boaventura tentou eliminar as críticas dos "rigoristas" e a legislação bonaventuriana procurou modelar a Ordem de acordo com uma nova realidade não aceita por todos os frades. Além disso, Boaventura encorajou a atividade intelectual em toda a Ordem, a pobreza era vista sob o ângulo intelectual com justificativa teórica nem sempre condizente com a prática das origens.

O ministro geral Boaventura de Bagnoregio deveria tornar-se, para a Ordem e para o complexo da Igreja, uma referência de ortodoxia e, ao mesmo tempo, um símbolo de conciliação entre as diversas e conflitantes correntes da Ordem no tocante à interpretação da pobreza da Regra. Durante seu generalato, procurou realizar uma aproximação entre aquilo que seriam os ideais primitivos da Ordem e as atribuições decorrentes de sua institucionalização e crescimento. Nesse período, os estudos no interior da Ordem foram regulamentados e intensificados. Se, por um lado, Francisco havia se manifestado contrário à construção de edifícios amplos para que fossem dotados de bibliotecas, Boaventura, por outro lado, combateria a suntuosidade, mas garantiria a presença dos livros e o hábito do estudo, pois, "além do exemplo de vida, espera-se que os clérigos possuam também o conhecimento seguro da verdade que anunciam." 346

Ele passou a integrar a Ordem Franciscana em virtude de uma série de pressupostos, entre os quais constam os motivos de gratidão, a influência de seu grande mestre Alexandre de Hales, bem como ponderadas reflexões. Boaventura pautava seu comportamento pelo desejo de realizar sempre os ideais da Ordem dos Frades menores, os quais se resumiam, nos dizeres dele, "em imitar Cristo em todo gênero de virtudes, ganhar muitas almas para Jesus Cristo e aderir a Deus por meio da contemplação." 347

Pode-se dizer, efetivamente, que Boaventura representa um exemplo de frade e de ministro geral da Ordem que levou a cabo o cumprimento de tais

\footnotetext{
346 BOAVENTURA DE BAGNOREGIO. Escritos..., Introdução, p. 23. O escrito em que Boaventura faria a defesa dos estudos é um pequeno texto intitulado Itinerário da Mente para Deus. Acerca do pensamento de São Boaventura, ver também: BOUGEROL, J.G. Saint Bonaventure et la sagesse chrétienne. Paris: Seuil, 1963 (Maîtres Spirituels).

${ }^{347}$ Usamos a edição bilíngüe latim e espanhol, publicada em Madri em 1949 pela O. F. M. Apud SÃO BOAVENTURA. Quaestiones disputatae de perfectione evangelica. In: Obras de San Buenaventura..., Notas Preliminares, p. 3.
} 
pontos essenciais do programa franciscano de "reforma", revelando-se um dos maiores praticantes e ao mesmo tempo defensores da perfeição evangélica e da pobreza franciscana. Ele seria considerado, não sem certa dose de razão, pela posteridade, como o segundo fundador da Ordem Franciscana.

A obra Expositio super Regulam Fratrum Minorum foi escrita na década de 1260 com o objetivo de expor, do verbo latino exponere, pôr para fora, com o intuito de trazer à luz a raiz da Ordem dos Menores, numa concepção jurídico-léxica de um catedrático. A obra contém doze capítulos correspondentes aos doze capítulos da Regra e tem como fio condutor a questão da pobreza ("não apropriação"), que tem como referencial a "lex fundamentalis" de 1223. É endereçada a todos os frades e, sobretudo, aos inimigos externos da Regra franciscana (em defesa do modelo apostólico mendicante). Assim como na Apologia pauperum contra calumniatorem, Boaventura, na sua Expositio, realiza uma defesa dos ideais e práticas mendicantes contra as acusações dos mestres parisienses, ao mesmo tempo em que eleva a virtude da pobreza, conferindo-lhe um valor inquestionável de perfeição evangélica. Ambos os escritos representam a tradição ortodoxa franciscana.

Desta forma, o primeiro aspecto que nos atrai a atenção na Expositio é a proibição da posse sobre os bens móveis e imóveis presente no capítulo um da Regra Franciscana. Porque, segundo Boaventura:

A Ordem dos Frades Menores, portanto, como também nenhuma pessoa da Ordem, tem algo próprio; mas, como servos de Cristo e feitos servis por Cristo, que por nós aceitou a forma de servo, vivem em casas alheias, imitando aquele que não teve nenhum título de domicílio próprio, nem onde pudesse reclinar sua santíssima cabeça. $E$, por causa do mesmo, usam livros e utensílios de outras necessidades que, por direito, são de outros. Pois, também "Cristo se alimentava de alimento alheio", como diz Jerônimo em $A d$ Nepotianum. Donde, Gregório IX, elucidando essa mesma Regra e distinguindo essa profissão de todas as demais, diz bem: "Dizemos que os Frades não devem ter propriedade, nem em comum e nem em particular, mas que a Ordem tenha o uso dos utensílios e dos livros e de seus móveis, os quais lhe é permitido ter, salvo o domínio dos lugares e dos edifícios, que é daqueles a quem se sabe pertencer. Também não devem vender os móveis ou trocar ou alienar de qualquer modo para fora da Ordem, a não ser que o Cardeal da Igreja 
romana, que na ocasião for o governador da Ordem, autorize ou aprove o Geral ou os Ministros provinciais acerca disso ${ }^{348}$.

Como vimos, a construção do texto de Boaventura deu-se por meio de artifícios jurídico-léxicos, que retomava ao mesmo tempo a exegese de Gregório IX sobre a questão da pobreza dos Menores; a diferenciação entre a proprietas e usus continuava seguindo a linha da Quo elongati de 1230 e não a da Ordinem vestrum de 1245. Desta maneira, a resposta iniciava com uma precisão conceptual-jurídica concisa: a Regra franciscana não dizia que os frades não deveriam ter algo, mas que não deveriam apropriar-se de algo. Consequentemente, os frades usam as coisas necessárias para a sobrevivência de seu corpo, mas não se apropriam de nada. Disso resulta a distinção entre "usus" e "proprietas" das coisas necessárias à vida pois os Frades menores têm somente o uso das coisas, cuja propriedade pertence ao papa (representante da Igreja), que se responsabiliza pela Ordem franciscana desde 1230. Seguindo este raciocínio Boaventuriano, concluimos que os frades usam sempre "coisas dos outros", como os filhos usam as coisas que pertencem ao "pai", tanto em sua presença, como em sua ausência. Da mesma forma, a esmola recebida pelos frades passava somente para o seu uso, mas se torna propriedade do papa imediatamente, que, se o solicitar, a Ordem deveria estar sempre pronta a restituir tudo o que tem (em uso). ${ }^{349}$ Enfim, os Frades não possuem propriedade nenhuma, por isso observavam a sua "herança" que era a Regra conforme Boaventura descreve nos trechos a seguir.

\begin{abstract}
Nisso se manifesta que todos os móveis, usados pela Ordem, são imediatamente bens da Igreja romana, por autoridade da qual o Cardeal da mesma Igreja, e nenhum inferior a ele, e sem o mesmo, tem licença de dispensá-la disso.

Embora, pois, em outras Religiões os bens sejam de tal maneira comuns às pessoas que, não obstante isso, são propriedade da comunidade e, como se distinguem as Congregações, assim também as propriedades das Congregações, esta Congregação, que é a comunidade dos Frades menores, nada pode reivindicar para si, neste mundo, a modo próprio de posse ou de domínio da sua comunidade, móvel ou imóvel ${ }^{350}$.
\end{abstract}

\footnotetext{
${ }^{348}$ Usamos a tradução brasileira dos Frades de Porto Alegre. ROBAERT, Plácido \& FASSINI, Dorvalino (org. e trad.). Exposição sobre a Regra dos Frades menores. São Boaventura. Porto Alegre: Evangraf, 2008, p. 27.

${ }^{349}$ MERLO, Grado G. Op. cit., pp. 123 e 124.

$350 \mathrm{O}$ grifo é nosso para reforçar os termos empregados. Utilizamos somente alguns trechos da Expositio com o objetivo de demonstrar que a pobreza da Regra havia sofrido um
} 
Ao longo da Expositio, Boaventura desenvolveu ponto por ponto da Regra com artifícios conceptuais jurídicos, em que percebemos um desenvolvimento da pobreza sob o prisma de um intelectual conhecedor dos textos clássicos greco-latinos, da Bíblia, da Igreja e da Ordem franciscana. $\mathrm{Na}$ Expositio, Boaventura explica os principais aspectos e especificidades da pobreza franciscana sob um viés mais elaborado; assim a proibição à propriedade do dinheiro, na qual nos informa:

\begin{abstract}
A respeito disso deve-se saber que pecúnia é palavra referente às coisas terrenas, cheirando mais à avareza do que o nome das riquezas, como ensina Santo Agostinho no capítulo XII da Cidade de Deus. Num sentido largo, chama-se de pecúnia tudo o que se possui temporariamente. Por isso, diz Santo Agostinho em seu livro De disciplina christiana: "Tudo o que possuem os homens na terra, todas as coisas das quais são senhores, chama-se pecúnia, seja um servo seja um campo". Noutro sentido, mais estrito, entende-se por pecúnia aquilo que serve de medida na troca das coisas. É assim que se entende em Atos: Teu dinheiro seja tua perdição; e no livro dos Provérbios se diz: Leva consigo a bolsa de dinheiro; e só voltará para sua casa na lua cheia. O mesmo diz o filósofo Aristóteles no livro quarto Ethicorum ${ }^{351}$.
\end{abstract}

A principal argumentação conceitual refere-se à renúncia à posse (modelo apostólico) segundo a Norma, que ganhava uma explicação retórica mais articulada de que a perfeição evangélica franciscana de altíssima pobreza estava condizente com a doutrina da Igreja e com o texto bíblico de Mateus 17, 27, no qual diz: nem os Apóstolos, nem Cristo fizeram uso de dinheiro em circunstâncias normais. Portanto, Cristo não possuía nada de próprio.

\begin{abstract}
Querendo, pois o Senhor arrancar inteiramente, por meio de seu servo Francisco, a raiz da avareza do horto fechado e da fonte selada, ordenou que os Frades não recebam dinheiro nem pecúnia nem qualquer outra posse de coisas terrenas, seja de gado ou de todas as outras coisas em geral, que possam arruinar a altíssima pobreza, e de um modo particular fala de moedas cunhadas. Esse preceito é tirado do Evangelho de Mateus: Não queirais possuir ouro nem prata nem dinheiro ${ }^{352}$.
\end{abstract}

desenvolvimento jurídico teórico por parte dos principais teóricos da Ordem, no caso Boaventura de Bagnoregio, somando, a saber, mais uma "leitura da pobreza" ao movimento Franciscano. ROBAERT, Plácido \& FASSINI, Dorvalino (org. e trad.). Op. cit., p. 28.

${ }^{351}$ IDEM, Ibidem, p. 68.

352 O grifo é nosso para destacar o uso das palavras empregadas. ROBAERT, Plácido \& FASSINI, Dorvalino (org. e trad.). Op. cit., p. 68. 
E mais adiante, Boaventura concluiu, em relação à posse de dinheiro, que os Frades não poderiam se apropriar de nada porque contradiz a Regra e os preceitos básicos do franciscanismo de não se apropriar de coisa nenhuma.

Por isso, como o doador do dinheiro intenciona dá-lo somente para que possa ser transformado no uso dos Frades, nunca quer que se transfira para eles o domínio, senão tão somente que seja transformado para as necessidades dos Frades. O mesmo diz, ainda, outra lei que "o louco, por princípio, não pode possuir, uma vez que não possui a vontade de possuir, mesmo que a coisa diga respeito ao corpo". Logo, enquanto permanece nos Frades a vontade inviolável de não adquirir para si nenhum direito de posses, embora, oxalá não aconteça, o dinheiro seja levado às suas mãos, em prol de suas necessidades, eles, todavia, não o recebem, seguindo aquilo que na Regra deles se proíbe receber ${ }^{353}$.

Entretanto, o ponto principal da Expositio de Boaventura concentra-se no capítulo VI, no qual define o princípio da não propriedade em quatro pontos, o abandono a todo o bem comum e a aceitação de viver na indigência (modelo apostólico).

Os Irmãos de nada se apropriem. Aqui, pela terceira vez, se afasta o terceiro perigo, a saber, o prejuízo que procede de apropriações em comum. E essa parte consta de quatro pontos. Primeiro, proíbe a apropriação. Segundo, impõe a mendicância, onde: recorram à esmola. Terceiro, desperta ao amor inviolável da pobreza, daí: esta é aquela excelência. Quarto, forma os Frades para a mútua consolação, daí: $\mathrm{E}$ em toda a parte onde estiverem.

Pois a respeito do primeiro ponto diz: Os Irmãos de nada se apropriem. Uma vez que acima proibiu a recepção de dinheiro, para que não creiam que lhes seja lícito receber outras coisas, como imóveis, exclui todas as coisas com uma afirmação geral, dizendo: De nada se apropriem, quer dizer: nem de propriedade pessoal nem geral da mesma comunidade, como diz o Papa, promulgando a Regra. Por isso, acrescenta: Nem casa, nem lugar, nem qualquer coisa. Isso será muito correto, porque, como diz Sêneca: "Viver-se-ia muito seguro se essas duas palavras fossem observadas: 'meu e teu'". É manifesto que, nesses tempos, faz-se mui grande tumulto na Igreja acerca do "nosso e vosso", 354 .

Desta forma, a pobreza pensada por um catedrático e ministro geral, mais do que um fato que requeresse comportamentos concretos, tornava-se um problema intelectual que entrava em conflitos eclesiásticos e eclesiológicos de complexidade jurídica. Pode-se dizer, efetivamente, que Boaventura, ao defender a propriedade comum com base nos graus de perfeição da pobreza,

353 IDEM, Ibidem, p. 81.

${ }^{354}$ IDEM, Ibidem, pp. 89 e 90. 
expõe um princípio específico dos Frades menores e não de toda a Igreja, mas concluiu que todos os clérigos não possuem bens, apenas o uso das coisas.

Do mesmo modo, parece falso impor essa forma de viver à Igreja de Deus. Os clérigos e os religiosos, que possuem os bens das igrejas, não são donos deles. Apenas possuem o uso, porque a lei De rerum divisione diz que "as coisas que são de direito divino não estão entre os bens de ninguém". Logo, os clérigos não possuem o domínio, mas somente o uso 355 .

Portanto, a pobreza Franciscana é Santa, meritória, providencial e útil para a Igreja, como assinalaram algumas constituições papais. Assim, o privilégio da pobreza dos Frades estaria na mais alta perfeição com base na renúncia à propriedade e à posse comum. Se compararmos a época dos escritos de Frei Francisco à época de Boaventura, percebemos uma mudança radical nos termos empregados, teóricos e práticos, porque o momento histórico Boaventuriano pedia uma reproposição das bases fundamentais da Ordem, uma reescrita adaptada e reformulada. Neste momento, na Ordem estava se formando uma sábia construção de teorias que justificavam e legitimavam, em relação às origens, as mudanças ocorridas até então. Boaventura era um dos principais construtores da perfeição evangélica franciscana como vemos no excerto abaixo.

\footnotetext{
$O$ outro modo convém também àqueles que não querem pôr-se debaixo do poder terreno, com o embaraço das posses: nada possuir como próprio (em particular) ou em comum. Donde, São Jerônimo em Ad Demetriadem: "É próprio da dignidade apostólica e da virtude perfeita vender todas as coisas e distribui-las aos pobres, e assim, com Cristo, voar leve e expedito para as coisas celestiais". E por causa disso acrescenta-se aí que "se podem administrar as coisas comuns sem impedimento da perfeição." Confesso ser isso verdadeiro porque, como acima foi demonstrado, não repugna à perfeição, por mais pobre que seja, assumir os bens eclesiásticos para administrá-los sob a ordem da Igreja, se o administrador, enquanto depender dele, opte sempre carecer deles, não afrouxando para si o rigor, enquanto a fraqueza o suportar. Pois, quem administra assim possui bolsas não para si, mas para os outros; e o ter, como o modo de ter, está em conformidade com o Salvador, como se via acima $^{356}$ [...] Quanto à terceira objeção já é manifesto. Porque todas as coisas móveis usadas pela Ordem são mera e imediatamente da própria Igreja romana. Assim, o ter coisas para a necessidade dos outros, naquele que entra pela porta, segundo o costume apostólico, em nada repugna à perfeição, como se demonstrou acima ${ }^{357}$.
}

\footnotetext{
355 IDEM, Ibidem, p. 90.

356 IDEM, Ibidem, pp. 91 e 92.

357 IDEM, Ibidem, pp. 92 e 93.
} 
Enfim, a mendicância franciscana era justificada por uma elaboração conceitual de que Cristo não tinha propriedade e pedia esmola; assim a Ordem franciscana, com o intuito de imitar a Cristo e seus apostólos, também não tinha propriedade e se caracterizava pela mendicância.

\begin{abstract}
O próprio Senhor, pois foi mendigo. Por isso diz Santo Agostinho, a respeito do Salmo 109: O homem indigente e mendigo foi perseguido, isto é, Cristo por Judas. E acrescenta: "Mas, como podemos compreender que ele foi mendigo, senão, talvez, porque disse à mulher samaritana: Dá-me de beber, e na Cruz: Tenho sede?". Ainda mais, embora dele fossem todas as coisas e a ele serem devidas por todos, ele, porém, não fez uso de seu poder exigindo tais coisas. Nem, tão pouco o exigiu por força de sua autoridade, senão a modo de pobre mendigo, assim como disse a Zaqueu: Desce depressa, porque hoje, etc. Sobre isso diz a Glossa: "Não convidado, Ele se convida". Dessa mesma forma também os Apóstolos procederam, aos quais, embora se deviam todas as coisas, todavia, como pobres, receberam por misericórdia o que se lhes dava para o necessário" ${ }^{\text {"58 }}$.
\end{abstract}

E Boaventura conclui na sua Expositio que a Regra de 1223 é a "lex fundamentalis" de toda a Ordem, claro que adaptada às circunstâncias do seu generalato e aos objetivos da Igreja para o movimento Franciscano naquele momento, após a sua "leitura" da norma, finaliza:

Entre essas coisas existem também outras que não são inseridas como preceitos. Nem as defino mais em especial, a não ser que, como digo, todas as palavras da Regra, sejam recebidas com reverência, e que se evite transgredi-las radicalmente, pois é certo que a Regra é dada como lei e ninguém se afasta da lei sem que se envolva nas trevas ${ }^{359}$.

Com a Expositio, Boaventura refazia os fundamentos teológicos da "perfeição cristã", expressada sobretudo no ideal franciscano dos primeiros tempos. As suas concepções jurídicas faziam parte de uma ação "de reforma" propositiva e repressiva de seu generalato, que tinha por objetivo intervenções de "eliminação do conflito" interno e uma formalização teológico-ideológica de ser Frade menor. No seu programa de "Reforma", Frei Boaventura agiu na direção jurídico-institucional e hagiográfico-teológica da seguinte forma: repropôs de forma "ordenada" ("escolar") as constituições de 1239, sem inovações significativas, e redigiu uma nova e definitiva legenda de São Francisco afim de finalizar as proliferações de hagiografias que tinham a função polêmica de sustentar as posições diversas e conflitantes de correntes internas

\footnotetext{
${ }^{358}$ IDEM, Ibidem, p. 96.
}

${ }^{359}$ IDEM, Ibidem, p. 132. 
da $\operatorname{Ordem}^{360}$. Em 1266, determinou a destruição de todas as hagiografias, inclusive os códices e as hagiografias "fora da Ordem" e distribuiu o seu modelo hagiográfico (Legenda Maior e Menor) para todos os conventos. $O$ modelo de São Francisco útil à Ordem e interpretado em chave teológicoespiritual, que completou a gradual ascensão para a perfeição evangélica foi identificado com o apocalíptico "anjo do sexto selo"361.

Portanto, os problemas de abusos na Ordem foram tratados como problemas disciplinares devido às imperfeições humanas, segundo Boaventura, por isso deveriam ser objeto de constante vigilância por parte daqueles que tinham a responsabilidade de orientar os frades, no caso o ministro geral, cardeal protetor e ministros provinciais. Assim, os problemas disciplinares enumerados no seu generalato, como a solicitação de heranças e legados, a avidez na busca de dinheiro para a construção de edifícios conventuais e igrejas etc, seriam corrigidos por meio das "constituições gerais" de 1260.

Em suma, Boaventura não pertencia à primeira geração de Frades menores, mas foi um dos melhores sintetizadores e "organizadores" da Ordem. Não é por acaso que ele é considerado um segundo fundador da Ordem pelos historiadores. A questão da pobreza continuava e continuaria sendo a inevitável diferença entre o modelo recebido do passado (Regra e Testamento de São Francisco) e a realidade que se vivia no presente (a aplicabilidade da "lex" no cotidiano dos conventos). Assim, segundo Merlo, "existe a ontológica impossibilidade de o modelo de referência (Regra) ideal ser a garantia das opções do presente; opções pelas quais o modelo não pode ser responsável, mas aqueles que nele se inspiram e professam querer torná-lo atual”362. Enfim, Francisco não era franciscano.

\subsection{Pedro de João Olivi (1248-1298) e a questão usus pauper na norma}

Após o generalato de Boaventura, inicia-se a formação definitiva de dois grupos na Ordem que repensaram a história da própria Ordem e a primeira geração menorita, a saber: os frades "espirituais" e os frades

\footnotetext{
${ }^{360}$ MERLO, Grado G. Op. cit., p. 119.

${ }^{361}$ A concepção de Francisco como o anjo do sexto selo foi retomada por Angelo Clareno sob o prisma dos Espirituais franciscanos.

${ }^{362}$ MERLO, Grado G. Op. cit., p. 122.
} 
"comunitários", que se enfrentavam de forma violenta não apenas no plano teórico, mas na realidade quotidiana e na praxis repressiva. A base do pensamento dos "espirituais" franciscanos foi Pedro de João Olivi (1248-1298) que desempenhou um papel fundamental para a elaboração do movimento dos Espirituais e para a consolidação de suas práticas. ${ }^{363}$

Nascido em Sérignan, no distrito de Hérault, no Languedoc, em 1248, Olivi entrou para a Ordem franciscana quando tinha doze anos, em 1260, no convento de Béziers. Ficou conhecido na Ordem franciscana por ter participado da comissão cardinalística que elaborou o material usado por Nicolau III na constituição Exiit qui seminat (14 de agosto de 1279) sobre a interpretação da Regra franciscana ${ }^{364}$.

Para Grado Merlo ${ }^{365}$, Frei Pedro de João Olivi é uma das chaves de leitura da história dos Menores nos últimos vinte e cinco anos do século XIII para entender a evolução da questão da pobreza. Pedro Olivi nunca obteve o título de mestre por motivos políticos, permanecendo bacharel formado. Exercia a função de Lector nos Studium dos Menores. Em 1282, no Capítulo geral de Estrasburgo, o ministro geral Bonagrazia, preocupado em sufocar o crescente debate interno surgido na Ordem, inicia as hostilidades contra Olivi. O mestre provençal criticava o "relaxamento" da pobreza na Ordem, que se afastava da "intenção primitiva" de Francisco, o progressivo crescimento de poder e prestígio da Ordem na sociedade e na Igreja, e ele ganhava cada vez mais adeptos. A pedido do ministro provincial de Provença, Arnaldo de Roquefeuil, todas as obras de Olivi foram postas a exame por teólogos da Ordem que dividiram as suas obras em "falsas" e heréticas, além de solicitarem ao ministro geral Bonagrazia que obrigasse Olivi a se retratar publicamente. ${ }^{366}$

Em outubro de 1283, após a morte do ministro geral, Olivi dirigiu-se a Paris para se explicar frente às acusações, permanecendo na cidade de Nîmes. Algumas de suas obras foram condenadas dois anos depois no Capítulo geral de Milão, no qual foi proibida a leitura de seus escritos. João

${ }^{363}$ MAGALHÃES, Ana Paula Tavares. "A trajetória e a obra de Pedro de João Olivi (c. 12481298): fundamentos para a elaboração do pensamento franciscano". Scintilla: Revista de Filosofia e Mística Medieval. Curitiba, vol. 4, n. 2, 2007, pp. 75-108. Disponível em: <http://www.saoboaventura.edu.br/pdf/scintillavol4n2.pdf>. Acesso em: 15 jan. 2010.

364 RUIZ, Carlos Mateo Martínez. Pedro de Juan Olivi. Opúsculos. Córdoba: Editorial de la Universidad Católica de Córdoba, 2005, p. 13.

${ }_{365}^{36}$ Ver MERLO, G. Op. cit., pp. 158-159.

${ }^{366}$ Cf. RUIZ, Carlos Mateo Martínez. Op.cit., p. 14. 
Olivi foi acusado de ser o cabeça de uma "seita" cismática e supersticiosa durante o período de vacância do cargo de ministro geral, o que contribuia para as divisões internas da Ordem. Para tentar resolver os problemas internos da Ordem, o papa Martinho IV promulgou a bula Exultantes in Domino no dia 18 de janeiro de 1283, a qual colocava a administração do uso dos bens nas mãos dos frades, afirmando que a propriedade era da Santa Sé e permitiria o uso de "síndicos" (leigos eleitos pelos frades para tratar dos assuntos econômicos da Ordem), com o intuito de vender, trocar, comprar, entre outras atividades relativas à administração como heranças e privilégios, o que de certa forma comprometia a pobreza da Ordem, por torná-la "proprietária". No Capítulo geral de Milão de 1285, foi eleito Arlotto de Prato como ministro geral, um dos sete teólogos censores de Olivi. No Capítulo geral de 1287 foi eleito Mateus d'Acquasparta (1287-1289), que rapidamente convocou Olivi para expor a sua doutrina acerca da pobreza franciscana, resumida no conceito do "usus pauper, ${ }^{367}$.

O resultado desta convocação foi que Olivi conseguiu ser nomeado Lector de teologia no Studium geral dos Menores em Santa Cruz de Florença pelo ministro geral Frei Mateus de Acquasparta, seu antigo mestre, com o consentimendo do Papa Nicolau IV (1288-1294), que tinha sido ministro geral da Ordem (o Frei Jerônimo de Ascoli). De um lado, frei Pedro Olivi era reconhecido pelo alto magistério escolar e, por outro lado, era afastado do sul da França tanto dos seus defensores quanto dos seus adversários. Mas, um ano após a sua chegada a Florença, frei Pedro João Olivi foi transferido para o Studium dos Menores de Montpellier, apesar de os ambientes franciscanos de Provença não estarem entre os mais tranquilos. Nesses anos, conseguiu estabelecer contato com frei Ubertino de Casale e provavelmente com frei Angelo Clareno, que foram figuras importantes para os Espirituais umbros. $\mathrm{Na}$ ocasião, conheceu também o jovem Dante e Conrado de Offida, de quem ouvia a história da visão de frei Leão sobre a resurreição de Francisco.

Nas obras de Paupere usu e De Perfectione evangelica, Olivi defendeu uma pobreza rigorosa e com prática no usus pauper no interior da Regra; já na

${ }^{367}$ RUIZ, Carlos Mateo Martínez. Op.cit., pp. 16 e 17. 
obra Declaratio in regulam ${ }^{368}$, ele fez uma exposição sobre a Regra de 1223, na qual elaborou uma vida cristã de acordo com o Evangelho. Nos dizeres de David Flood, Olivi considerava a vida proposta pela Regra como uma continuação da história de Francisco. Segundo um dos seus postulados, início de uma série de estudos em que Olivi não elaborava uma teoria da vida cristã de acordo com os evangelhos, mas, como ele mesmo deixa transparecer na introdução da declaratio, ele compreendia a Regra de Francisco como um documento formalmente adequado a um projeto de vida plenamente evangélico ${ }^{369}$. Assim, a Regra de Francisco de Assis seria para ele um documento formalmente adequado a um projeto de vida plena evangélica e 0 Testamento foi a última mensagem de Francisco aos seus irmãos a fim de impedir que alguém se dirigisse a Roma no desejo de fazer abrandar os rigores da Regra. Para Olivi, o Testamento não impôs uma nova lei aos frades, pois Francisco não possuía autoridade para fazê-lo conforme a bula Quo elongati de 1230 de Gregório IX ${ }^{370}$.

No seu comentário à Regra, Olivi definiu três pontos, a saber: a teoria, a localização social e o sentido histórico do documento. $O$ primeiro ponto corresponde à afirmação da identidade entre a Regra Franciscana e o Evangelho. Assim, o modo de vida de Francisco e companheiros corresponderia exatamente ao modo de vida de Cristo e seus apóstolos; Francisco, como um alter Christus. No segundo ponto, ele confere validade evangélica a uma prática da Regra, na qual os homens que viviam de acordo com o Evangelho faziam parte da Igreja e eram submissos ao papa. Desta forma, quanto mais um homem seguia o Evangelho em sua vida, mais ele era obrigado a enraizar-se na Igreja e na autoridade do papa. E o terceiro ponto, Olivi coloca a vida proposta pela Regra como a continuação da história de São Francisco de Assis, conforme já mencionamos.

Enfim, a Regra era mais que um gênero de vida proposto por Francisco, ela unia os frades a Francisco como uma forma de continuação do

${ }^{368} \mathrm{O}$ intuito aqui não é de analisar as obras citadas, apenas discutir o conceito do usus pauper que foi apropriado pelo papa Nicolau III na Exiit qui seminat sob o ponto de vista dos frades da Comunidade e por Angelo Clareno na Expositio Super Regulam Fratrum minorum sob o viés dos Espirituais umbros.

${ }^{369}$ FLOOD, David. "Pierre Jean-Olivi et la Règle Franciscaine". In: Franciscains d'Oc. Les Spirituels ca 1280-1324. Toulouse: Cahiers de Fanjeaux, Privat Editeur et Centre d'Etudes historiques de Fanjeaux, 1975, pp. 142-143.

${ }^{370}$ IDEM, Ibidem, p. 147. 
projeto misterioso que o Espírito Santo havia iniciado nele. Assim, a Ordem franciscana desempenhava um papel histórico salvífico de programa evangélico que as outras instituições não desempenhavam porque a história de vida vivida por Francisco e a Regra vivida pelos Frades na Ordem configuravam-se no mesmo programa na economia da salvação. ${ }^{371}$.

Portanto, nos seus comentários à Regra dos Menores, resumia-se sobretudo o papel histórico salvífico da Ordem franciscana na cristandade. Ele não contestava a hierarquia da Igreja e via na Regra uma condição para a obediência como parte essencial da perfeição evangélica ${ }^{372}$. Olivi pertencia às estruturas institucionais do seu tempo, visto que no conjunto das suas obras ele não representaria um herético na Ordem franciscana, mas um "dissidente" dos Menores.

Para Olivi, a questão da pobreza da Regra resumia-se nas seguintes observações: a renúncia a toda forma de domínio e de propriedade; seria a mais alta perfeição da pobreza evangélica; assim, ser "pobre" incluía também (e sobretudo) o esforço de fazer um "uso pobre" (usus pauper) das coisas, que deveria ser elevado ao mais alto grau da necessidade, ou seja, limitar ao máximo as necessidades da vida dos frades, considerando as suas vocacionais atividades tanto na cura das almas quanto nos estudos. Desta forma, temos uma nova tentativa de adaptar a pobreza codificada na Regra à pobreza vivida (aplicabilidade da "lex"), tirando toda a cobertura jurídica dada pelos papas pela Quo elongati de 1230, Ordinem vestrum de 1245, Exiit qui seminat de 1279 , entre outras bulas, que, mesmo não violando o ideal pauperista, trazia uma práxis que estimulava o "relaxamento" da pobreza absoluta ou os comportamentos dos frades restringiam-se à superficialidade do uso das coisas.

Nos anos de 1290, as velhas contendas da pobreza chegaram aos ouvidos de Nicolau IV, que atendendo a um pedido do ministro geral Raymond Geoffroi, pediu um exame "de certos frades que pareciam ter iniciado um cisma na província de Provença, condenando o estado dos outros frades e considerando-se mais espirituais que os outros", segundo a crônica dos XXIV Gerais. A partir desta crônica é que surge o nome de "Espirituais" para

\footnotetext{
371 IDEM, Ibidem, pp. 140 e 141.

${ }^{372}$ MAGALHÃES, Ana Paula Tavares. Op. cit., p. 92.
} 
designar a "dissidência" franciscana, enquanto a outra facção da Ordem, que dava apoio ao governo e se considerava como fiéis ao espírito e às palavras da Regra, aos numerosos compromissos e adaptações que permitiram fazer, sobretudo em matéria de pobreza e vida apostólica, autodenominou-se desde o início de "a Comunidade".

A crônica dos XXIV Gerais também menciona o castigo sofrido pelos frades da França meridional por terem semeado a divisão na Ordem Franciscana.

Em maio de 1296, durante o Capítulo geral de Assis, Bonifácio VIII (1294-1303) obrigou Raymond a renunciar ao cargo de ministro geral e a Assembleia elegeu João Minio de Murrovalle, outro dos antigos sete censores de Olivi, que abertamente era favorável a "Comunidade", e amigo pessoal de Bonifácio $\mathrm{VIII}^{373}$.

Quanto ao papel de Pedro João Olivi no espiritualismo franciscano concordamos com Raoul Manselli, quando expressa que não podemos dizer que Olivi foi um chefe porque o Espiritualismo franciscano não é uma parte, nem uma facção, é uma tomada de consciência. "Nós diriamos antes que Olivi, por extensão de sua cultura, pela profundidade de sua preparação e pelo nível de sua inteligência, foi quem melhor soube perceber o valor e os sentidos religiosos, históricos e enfim humanos do Espiritualismo franciscano"374. Ele passou os últimos anos de sua vida no convento de Narbonne, venerado por alguns clérigos e pelo povo, algo que cresceria pouco a pouco até converter-se num autêntico culto popular.

Em relação à Regra, Olivi considerava um pecado mortal, indesculpável, a defesa daqueles frades da "Comunidade" que faziam transgressões da pobreza por meio de abusos cometidos contra a Regra apostólica, bem como perseguiam aqueles que queriam observar a Regra em toda a sua pobreza absoluta. Os abusos denunciados eram desde o uso de hábitos luxuosos e de calçados, a andar a cavalo; em resumo, o viver com comodidade e rejeição do uso simples das coisas. Olivi faleceu no dia 14 de

\footnotetext{
${ }^{373}$ RUIZ, Carlos Mateo Martínez. Op.cit., pp. 16 e 17.

${ }^{374}$ MANSELLI, Raoul. "L'idéal du Spirituel". In: Franciscains d'Oc. Les Spirituels ca 1280-1324. Toulouse: Cahiers de Fanjeaux, Privat Editeur et Centre d'Etudes historiques de Fanjeaux, 1975, p. 123.
} 
março de 1298, Depois de morto teve seu túmulo violado e foi excomungado pela Igreja.

Segundo David Flood, Olivi apresentou um ponto de vista muito equilibrado sobre a Regra bulada e sobre a história da instituição franciscana. $\mathrm{Na}$ verdade, a condenação dos seus escritos estava ligada mais às disputas clericais, nas quais os regulares tentavam restringir a participação dos Menores nas universidades, do que às influências joaquimitas do autor. Existem poucas críticas às suas obras e nenhuma condenação no Concílio de Vienne (13101312), época que atingiu o ápice do debate acerca da pobreza normativa franciscana ${ }^{375}$.

\subsection{O princípio da intocabilidade da Regra na obra Expositio super Regulam Fratrum Minorum de 1323 de Angelo Clareno (1245-1337)}

Nesta parte analisaremos alguns excertos sobre o conceito de pobreza franciscana na obra Expositio super Regulam Fratrum Minorum de frei Angelo Clareno para melhor compreender a "leitura" da Norma feita por um representante dos Espirituais, um dos "resistentes" ao enquadramento tradicional da Ordem. Antes de analisarmos os trechos propriamente, retomamos a ideia de pobreza franciscana presente na Regra bulada de 1223, que tem como ponto fundamental o viver sem propriedade nem individual, nem em comum, premissa que norteia toda a documentação legislativa da Ordem, sendo o principal motivo das contendas jurídicas acerca da paupertas dos Menores. Assim, o viver pobre não se limita ao âmbito interior do homem, aplica-se no sentido interior e exterior, com consequência no campo material, visível às demais pessoas.

Angelo Clareno (1245-1337) foi um importante representante dos chamados "Espirituais franciscanos" da Marca de Ancona. Para Felice Accrocca, um dos principais estudiosos deste pensador, ele nasceu em Fossombrone e embora haja controvérsias em relação a sua data exata de nascimento, o ano de 1245 parece ser o mais indicado. Frei Clareno entrou para a Ordem menorita entre os anos de 1257 e 1258. Seu nome de

${ }^{375}$ FLOOD, David. Op. cit., p. 151. 
nascimento era Pietro de Fossombrone, depois mudou para Angelo Clareno; não se tornou líder dos rebeldes da Marca de Ancona, mas procurou "viver franciscanamente como e onde podia", segundo Raoul Manselli, o que causava uma certa "contestação" entre os demais frades da "Comunidade" que seguiam uma linha mais institucional de adaptações e de obediência ao papa.

O termo "Espiritual" aqui empregado nasceu de um posicionamento de alguns frades que se opunham à introdução de mudanças institucionais na Ordem e tinham como objetivo repropor o franciscanismo das origens como uma "forma de resistência" ao enquadramento da Ordem pela Igreja. Com o passar do tempo, aumentaram as divergências entre os dois grupos de franciscanos, "Comunidade" e "Espirituais", com perseguições, acusações, condenações e mortes. O próprio Clareno foi preso, exilado, perseguido, expulso da Ordem, submetido à inquisição, e, mesmo assim, deixou uma "proposta" por vias não oficiais a outros frades através dos seus escrito. Feitas estas observações, podemos classificá-lo como um representante dos "Espirituais" da Úmbria. Porém, devemos ter em mente as observações de Edith Pásztor: "Se considerarmos o Testamento de Francisco como o primeiro escrito "de inspiração espiritual" coloca-se em exaltação a pobreza rigorosa como a única característica dos Espirituais. A menos que se justifique por mais "razões sólidas" o uso do termo espiritual e deixe de lado quando se trata de Olivi, para dar destaque à tese segundo a qual os Espirituais seriam distintos na história franciscana devido a uma desobediência às autoridades

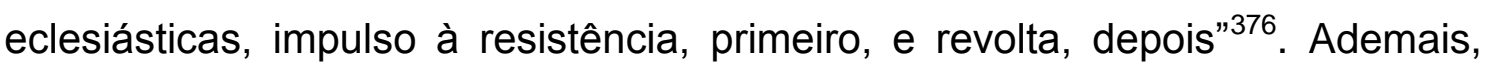
não se pode falar de um franciscanismo Espiritual como um fenômeno uniforme ou unitário. Se analisarmos as obras dos "Espirituais" veremos o quanto era complexa a interpretação da Regra de 1223 e da figura de Francisco.

A manifestação dos "rebeldes" da Marca de Ancona teve início em 1274 após boatos sobre o Concílio de Lyon no qual Gregório X (1271-1276) teria obrigado as Ordens mendicantes a aceitar a propriedade em comum de tradição monástica e canonical, modificando a estrutura franciscana e contrariando um dos preceitos básicos da Regra de 1223 que já mencionamos,

\footnotetext{
${ }^{376}$ PÁSZTOR, Edith. "L'immagine di Cristo negli Spirituali". In: Chi erano gli spirituali. Atti del III Convegno Internazionale. Assisi, 16-18 ottobre 1975. Assisi: Società Internazionale di Studi Francescani, 1976, pp. 109 e 110.
} 
os Frades menores não podiam ter propriedades nem em comum nem individual, não podiam receber dinheiro e deveriam viver na pobreza segundo a norma. A Igreja seria a verdadeira proprietária dos bens dos frades desde a época de Gregório IX.

Quando os frades da Marca de Ancona souberam desta interferência pontifícia, iniciou-se a primeira rebelião, o que propiciou um desencadeamento de ideias entre alguns frades, como, por exemplo, a volta às origens da Ordem e a criação de um modelo da primitiva "fraternitas"; o movimento maior atingiu esta região na qual Frei Angelo Clareno estava inserido.

Como já foi dito, a obra Expositio super Regulam Fratrum minorum tem como fio condutor a questão da pobreza ("não apropriação"), que tem como referencial a Regra bulada de 1223 e o Testamento de Francisco de 1226 . O escrito que propusemos a discutir foi produzido entre os anos de 1321 e 1323, no período em que o frade Clareno permaneceu junto ao mosteiro de Subiaco. A obra contém doze capítulos, com uma introdução e um epílogo que correspondem exatamente aos doze capítulos da Regra bulada. É endereçada a frei Tomás - difícil de identificar quem seja, provavelmente um dos seus discípulos que lhe fez o pedido expresso de fornecer por escrito aquilo que era a pura, simples e última intenção de Francisco referente à Regra inspirada por Cristo - e Clareno propõe com este comentário iluminar ou trazer à tona a verdadeira intentio que Francisco teve ao escrever à Regra. Alguns capítulos da Regra são comentados brevemente, a outros são dados maiores destaques, não havendo uma regularidade. Porém, parece que a obra não teve um público grande além do meio franciscano, prova disso é que não se conhece uma versão em língua vernácula da mesma, apenas a versão em latim.

Ao longo da obra, percebemos que frei Angelo conhecia muito bem os escritos de Francisco de Assis, a Regra bulada e não bulada ${ }^{377}$, o Testamento, admoestações e saudações às virtudes; conhecia também a obra de Tomás de Celano e de Boaventura de Bagnoregio, que frequentemente é citado algumas vezes indicando a fonte, outras vezes citando as cartas mas sem

377 A Regra não bulada é amplamente citada na obra de Angelo Clareno, às vezes, confrontando o texto das duas Regras, a de 1221 e a 1223. Isto é uma importante informação, visto que Pedro de João Olivi (1248-1298) nunca cita a Regra de 1221 nos seus escritos. Pedro de João Olivi influenciou de maneira muito significativa Clareno com o princípio do usus pauper. 
indicar a fonte, depois cita de maneira não literal episódios hagiográficos, enfim, conhece outras crônicas não oficiais como o Espelho da Perfeição, a obra de frei Leão; todas essas referências são perceptíveis através do conteúdo e da retórica do seu texto. Entretanto, segundo os estudiosos da Expositio, Clareno tinha um amplo conhecimento de três fontes essenciais: bíblica - principalmente citações do Novo Testamento, sendo o Evangelho de Mateus e Lucas os mais utilizados, - patrística - Basílio Magno e Santo Agostinho - e franciscana. Ele utilizou também fontes pontifícias e jurídicas. Segundo a suiça Lydia von Auw isso significa que Clareno era um clérigo com boa formação eclesiástica: "Angelo Clareno admitiu o estudo das Santas Escrituras e aplicou-se nisso com fervor. Ele conhecia não somente os Salmos mas os evangelhos, as Epístolas, o Antigo Testamento. E ele se interessava pelos comentários e comentadores da Bíblia [...] Havia nele um certo instinto histórico que o crescimento que exigia a volta às origens: origens da Igreja, da Regra franciscana, ao Breviário. A Igreja toda tinha um passado no qual se inseria a vida de São Francisco" 378 .

Ao escrever a Expositio, Clareno tinha em mente que um grupo de frades da Marca de Ancona lutava para preservar a verdadeira intentio de Francisco, uma forma de vida na qual a pobreza ocupava o papel central. Além disso, para frei Angelo Clareno, a Regra de 1223 foi diretamente ditada de Cristo para Francisco como modelo de vida a ser seguido.; o seguimento de Cristo e não a imitação não representava uma novidade; trazia-se uma leitura desta "sequela Christi" através do sofrimento da cruz e, de modo particular, ligada à perseguição que Clareno e seu grupo haviam sofrido - enxergava Cristo como pobre e perseguido. Conforme Edith Pásztor, "segundo Angelo Clareno, Cristo havia convidado Francisco a uma sequela, a uma imitação, a uma aderência completa, de maneira a 'omnis cogitatio tua in me et de me sit, et omnia verba tua ex me, pro me, coram me sint, et omnia opera tua propter me et ad mei nominis honorem et gloriam semper fiant." ${ }^{379}$.

Da seguinte forma, a Regra e o modo de vida no prefácio da obra de Clareno são enunciados.

378 AUW, Lydia Von. "À propos d'Angelo Clareno". In: Chi erano gli spirituali. Atti del III Convegno Internazionale. Assisi, 16-18 ottobre 1975. Assisi: Società Internazionale di Studi Francescani, 1976, p. 210.

${ }^{379}$ PÁSZTOR, Edith. Op. cit., p.113. 
... et aliter sentientibus manifeste patere ipsum immediate a Christo accepisse regulam et intelligentiam eius, que plene et summe concordat moribus et exemplis Christi vite et Matris eius et apostolorum et sanctorum omnium perfectorum, qui eum precesserunt et sancte Romane Ecclesie et omnium summorum pontificum, qui nunc usque fuerunt in ea, auctoritate et testimoniis roboratur. ${ }^{380}$.

E conclui que a intenção de Francisco foi revelada através da Regra, que é identificada diretamente com o Evangelho.

Sed ex verbis et scriptis sancti Francisci indubitanter colligitur, quod ipse non ab homine neque per hominem, sed per revelationem lesu Christi habuit, qui ei frequenter apparuit, et suis eum stigmatibus consignavit, quod ipse Evangelium pro regula acciperet et promicteret secundum quod Evangelium sub voto cadit, et hoc sibi concedi ab Ecclesia postularet. ${ }^{381}$.

O principal objetivo desta obra era um projeto evangélico de "retorno" ao franciscanismo primitivo com a ideia de desprendimento e de não apropriação das coisas. Com isso, a discussão em relação à Regra Franciscana visava a conduzir os franciscanos contemporâneos a encontrarem-se com o franciscanismo da primeira "fraternitas". Para isso, os frades deveriam fazer um uso simples (pobre) das coisas e não deveriam receber bens fixos, pressuposto que tem origem nos documentos legislativos da Ordem. Segundo Clareno, a Regra Franciscana devia ser observada na sua pureza, sem glosas, tendo o Testamento como guia e opúsculo de maior observância.

No período em que Clareno redigia os seus Comentários à Regra, certamente ele conhecia as Constituições papais que fizeram uma interpetação pelo viés jurídico da pobreza franciscana da Regra de 1223, a saber, a Quo Elongati de Gregório IX (1227-1241) de 1230, a Ordinem vestrum de Inocêncio IV (1243-1254) de 1245, a Exiit qui seminat de Nicolau III (1277-1280) e a Exivi de paradiso de Clemente V (1305-1314) de 1312. Ademais, o Testamento de 1226 foi constantemente negado, enquanto valor jurídico, pelos papas acima mencionados. Por isso, o trecho a seguir é revelador: "Quintodecimo, quia non debent mictere glosas in regula, neque in verbis sui testamenti, que contrarium

${ }^{380}$ ANGELI CLARENI, Expositio super Regulam Fratrum Minorum, a cura di P. G. Boccali ofm. com introduzione di F. Accrocca e traduzione italiana a fronte di P. M. Bigaroni ofm., S. Maria degli Angeli, 1995, p.112.

381 IDEM, Ibidem, p. 186. 
intentioni recte et veraci, quam Dominus sancto Francisco dedit, contineant, vel esponant." ${ }^{382}$. Frei Clareno utilizou-se de um trecho do Testamento de Francisco no qual menciona que à Regra e ao Testamento não devem ser feitos glosas ou acréscimos e concluiu que isso contradizia a verdadeira intentio do fundador da Ordem Franciscana, porque para ele a Regra era identificada com o Evangelho, por isso não poderia ser reduzida a um texto meramente jurídico; e como ela havia sido inspirada por Cristo a Francisco, não poderia ser modificada; afinal, Cristo é o modelo central do cristianismo.

No entanto, ao fazer os seus Comentários à Regra, Angelo Clareno também trouxe uma contribuição para enriquecer a questão da pobreza e a discussão jurídica que se formou em torno dela: a ideia original de que a Regra havia sido ditada diretamente por Cristo a Francisco e o Testamento deveria ser lido junto à Regra segundo o próprio texto do Testamento, além do seguimento de Cristo e não a sua imitação. Na época de redação da Expositio, acirraram-se as discussões no interior da Ordem dos Frades menores, principalmente nestas duas primeiras décadas do século XIV.

Voltando ao texto, os cinco primeiros capítulos consistem numa preparação para o conteúdo central da obra que é a pobreza, que tem como cerne a não-apropriação de nada, nem de propriedades e nem das coisas. Clareno apóia o seu discurso em dois frades: um é frei Leão, um dos primeiros companheiros de Francisco que teria conhecido a "verdadeira intenção" de Francisco que já discutimos no início deste capítulo e o outro é o frei provençal Pedro de João Olivi ${ }^{383}$, um teólogo que foi diversas vezes questionado pela Igreja e pela Ordem dos Menores.

Entretanto, os excertos mais importantes para a nossa análise em relação à pobreza é a interdição de posse que está no Capítulo I da Expositio.

Secundo, in modo recipiendi fratres, quia mandat venientibus ad religionem, omnia iuxta verbum sancti Evangelii dare pauperibus. [...] Sexto, quia nullo modo possunt denarios vel pecuniam, aut campos

\footnotetext{
${ }^{382}$ ANGELI CLARENI, Op. cit., pp. 160 e 162.

${ }^{383}$ Sobre a influência de Pedro João Olivi, nos dizeres de Lydia von Auw, "Ainsi Angelo nous fait connaître sous quels signes sa vie s'est déroulée: un désir intense de voir l'Ordre franciscain réformé, une vénération fervente pour Pierre Olivi. Celui-ci n'est pas pour Angelo un simple maître de théologie et de spiritualité. II a été élu et envoyé par Dieu comme saint François l'a été". Cf. AUW, Lydia von. "Angelo Clareno et les spirituels du Midi". In: Franciscains d'Oc. Les Spirituels ca 1280-1324. Toulouse: Cahiers de Fanjeaux, Privat Editeur et Centre d'Etudes historiques de Fanjeaux, 1975, pp. 243 e 244.
} 
vel vineas, aut animalia vel quecunque legata et testamenta recipere, nec per se, nec per interpositam personam. Utpote qui promiserunt iuxta perfectionem evangelicam nichil proprium habere 'neque in speciali neque in communi'. Septimo, quia non possunt vendere neque emere, neque pro aliqua causa in iudicio litigare, sive iusta sive iniusta. ${ }^{384}$.

A característica da pobreza franciscana é não ter propriedades, não possuir nada, o que aparece com maior ênfase no excerto.

\begin{abstract}
Nudi enim nudam crucem Christum sequentes ferunt, et nullis herent seculi curis. Sed tanquam peregrini et advene in hoc seculo, in paupertate Domino famulantur, de crastino non curantes. Sine domo, sine loco et absque rerum omnium dominio et proprietate viventes, nec cellaria nec granaria, vel rei cuiuscunque promptuaria habent. Aurum et argentum et pecuniam omnem odiunt et respuunt ut venenum. ${ }^{385}$.
\end{abstract}

Uma discussão importante das pesquisas mais recentes sobre Angelo Clareno é que não existe um acordo historiográfico acerca da problemática do suposto joaquimismo de Clareno. Joaquim de Fiore é citado uma única vez em seus escritos, de maneira pouco acolhedora, portanto não haveria uma influência significativa joaquimita em seus escritos. Para Lydia von Auw o joaquimismo estava "no ar", portanto é inútil pensar na influência joaquimita em Clareno. Apesar de mencionar "a nova idade do Espírito", centro da reflexão joaquimita, Clareno pensava numa "innovatio vite Christi", porque ele identificava Francisco com o Anjo do sexto selo, não dizia que este inauguraria a idade do Espírito, nem que levaria um novo Evangelho eterno, mas que seria um imitador e inovador da vida e da perfeição de Cristo $^{386}$.

Para Angelo Clareno, na sua obra maior Historia septem Tribulationum Ordinis minorum, a observância de forma simples e sem glosa da Regra e Testamento era essencial, visto que ambos foram redigidos por "vontade divina". Desta forma, ele acabou construindo a ideia de necessidade da observância do Testamento e do princípio da intocabilidade da Regra.

Para a Ordem Franciscana, o ano de 1323 foi marcado pela bula Cum inter nonnullos de João XXII (1316-1334), que considerou herética e errônea a concepção de pobreza franciscana de que Cristo e os apóstolos não tinham propriedade, negando o principal fundamento da identidade franciscana de

\footnotetext{
${ }^{384}$ ANGELI CLARENI, Op. cit., p. 154 e 156.

${ }^{385}$ IDEM, Ibidem, p. 166.

${ }^{386}$ ANGELI CLARENI, Op. cit., pp. 70 e 71.
} 
toda a Ordem. Desta maneira, o papa João XXII revogou as providências da bula Exiit que seminat de 1279 de Nicolau III (1277-1280) em relação à Regra franciscana; assim a Santa Sé não tinha mais a "reserva de propriedade" sobre os bens dos frades, eliminando o fundamento jurídico sobre o qual se apoiava o conceito franciscano de pobreza, presente também na Expositio de Angelo Clareno.

Frei Clareno, ao aconselhar os seus interlocutores, nem sempre franciscanos, a seguir o caminho espiritual por meio de uma pobreza franciscana mais rígida, observando os trechos da Regra e do Testamento de Francisco simultaneamente, objetivava viver a perfeição evangélica num esforço incessante de conciliar a fidelidade a Francisco aos textos mencionados e à obediência à Igreja. Enfim, para o frade Angelo Clareno esses textos legislativos revelariam à verdadeira "intentio" de Francisco de Assis, por isso seriam inseparáveis e obrigatórios para se atingir a salvação e a perfeição evangélica. Também segundo 0 frade não se podiam fazer interpretações jurídicas dos escritos de Francisco, visto que eram ditados diretamente por Cristo.

Em resumo, ao analisar o conceito de pobreza de Clareno na sua vertente de "não apropriação" que partiu do frei provençal Pedro de João Olivi (1248-1298) com o princípio de usus pauper, revelou-se uma posição medieval "contestatória" e evangélica num período em que o movimento Franciscano se dividia concretamente em frades "Espirituais" (sobretudo com os "rebeldes" na Província da Marca de Ancona) e os frades da "Comunidade".

Por último, os "Espirituais" eram "filhos" de uma tradição especial transmitida por frei Leão e frei Egídio, primeiros companheiros de Francisco, que seguiram uma pobreza total no sentido de estado de espírito ou idealizada, tendo a Regra de Francisco de Assis assemelhada ao Evangelho de Cristo e o Testamento como diretriz obrigatória para o seguimento de Cristo. Discordamos de Stanislao da Campagnola em relação à Regra e Testamento de Francisco de Assis, quando menciona que os "Espirituais" seguiam uma interpretação rigorosa e literal destes documentos. Como viemos assinalando, é preciso analisar a obra de Clareno sem a ideia pré-concebida da historiografia tradicional de que os "Espirituais" franciscanos interpretariam a pobreza de maneira rigorosa e fanática. Nem sempre eram destoantes da 
ortodoxia franciscana; sendo assim, os Espirituais representavam mais a dissidência do movimento Franciscano do que a heresia.

Os "Espirituais" faziam uma "leitura" de um modelo de Francisco e do franciscanismo à margem da institucionalidade. A "leitura" idealizada dos "Espirituais" sobre frei Leão também foi um modelo bastante criticável, tendo em vista o anti-modelo frei Elias. As práticas da pobreza franciscana são bem mais complexas do que esses modelos de frades, condizentes ou não com o franciscanismo primitivo. Essas práticas da pobreza voluntária sob o prisma franciscano à margem ou não da institucionalidade são representações da pobreza importantes para entendermos as relações sociais de uma Ordem religiosa de grande popularidade na Idade Média. Por isso, os modelos formulados a partir das hagiografias não contribuem em nada para o entendimento da complexidade da contenda jurídica formada em torno da "herança genética" do franciscanismo.

Como bem coloca Pietro Maranesi, "o último desenvolvimento das posições da ala dos Espirituais na polêmica com as elaborações intelectuais dos Conventuais é o "Comentário à Regra de Angelo Clareno". Composto nos anos de 1321-1323, quando os Espirituais estavam reduzidos ao silêncio pelas duras intervenções de João XXII e afastados da Ordem, Clareno exprimiu em seus textos toda a amargura e a desilusão do fim de uma esperança" de um retorno a um franciscanismo simples das origens. ${ }^{387}$. Só pelo fato de a Expositio super Regulam Fratrum Minorum ser o último registro de um período conturbado da história da Ordem franciscana merecia uma revisão historiográfica. Porque foi uma obra produzida dentro de um contexto de crise institucional da Ordem menorita, por isso é bastante reveladora. Além disso, reafirmamos que os Comentários à Regra de Clareno não contradizem a premissa básica da pobreza normativa. É uma representação da pobreza franciscana de um grupo que estava fora da institucionalidade porque foram limitados pela Igreja e pela cúpula da Ordem franciscana do período.

Ao dar ênfase ao Testamento de Francisco, Angelo trazia à tona o problema das origens do franciscanismo, as polêmicas interpretações papais

387 MARANESI, Pietro. I commenti alla Regola francescana e la questione dello studio. In: Studio e Studia: le scuole degli Ordini Mendicanti tra XIII e XIV secolo. Atti del XXIX Convegno internazionale. Assisi, 11-13 ottobre 2001. Spoleto: Centro Italiano di Studi sull'Alto Medioevo, 2002, p. 64. 
sobre a pobreza da Regra e o questionamento em torno da institucionalização do movimento Franciscano, que foi de uma certa maneira engessado e podado com as várias medidas jurídicas pontíficias de enquadramento. A pobreza só podia ser interpretada ou vivida dentro daquilo que a lgreja permitia; talvez pela experiência eremítica e prática, Clareno tinha uma "contestação" mais aprofundada em relação à institucionalização e à aplicabilidade da Regra no cotidiano dos conventos.

Em 1290, o ministro geral Frei Raimundo Gaufredi (1289-1295) chegou à Marca de Ancona, onde mandou libertar os frades "rigoristas" e pauperistas, como freis Angelo e Tomás de Tolentino, Marcos de Montelupone, frei Liberato e frei Angelo Clareno; para eles iniciava-se um novo período de "tribulações", ligadas à sua firme intenção de viver a própria experiência franciscana de forma rigorosa no sentido idealizado de estado de espírito e de acordo com a Regra e Testamento de São Francisco.

Em 1300, Angelo Clareno tinha um olhar pessimista em referência aos rumos da Ordem e declarou depois de todos os processos e de todas as lutas que era melhor sofrer todas as espécies de tormentos e a morte, que se separar da obediência do seu Chefe, do seu vigário e da sua Igreja ${ }^{388}$. Com isso, deduzimos que a relação Regra-Testamento não era um assunto totalmente encerrado e menos ainda um consenso homogêneo entre os frades daquele período. Como consequência, frei Angelo Clareno e frei Ubertino de Casale tiveram a sua identidade negada e não foram integrados na Ordem franciscana. No entanto, foram os precursores do princípio da intocabilidade da Regra e elegeram o Testamento como o opúsculo de maior observância, como algo mais próximo do franciscanismo das origens, sendo ambos parte de um conjunto dos principais comentadores da Regra no século XIV.

Em suma, ao analisar alguns trechos da obra Expositio entendemos que a qualidade dos Espirituais não encontra correspondência na quantidade de adesões que eles conseguiram obter como nos aponta Grado Merlo. Mas, a importância de Clareno estaria no fato de ele ter difundido uma "espiritualidade" intimamente preocupada com um "retorno" às origens, que foi cerceada pela

\footnotetext{
${ }^{388}$ VAN DIJK, Willibrord-Christian. "La représentation de Saint François D'Assise dans les Écrits des Spirituels". In: Franciscains d'Oc. Les Spirituels ca 1280-1324. Toulouse: Cahiers de Fanjeaux, Privat, Editeur, et Centre d'Etudes historiques de Fanjeaux, 1975, pp. 206 e 207.
} 
Igreja através da inquisição; e a historiografia italiana mais recente tem assinalado a necessidade de um estudo mais aprofundado dos seus escritos, entre eles, a Expositio super Regulam Fratrum Minorum, da qual levantamos algumas questões preliminares. Como já mencionamos, vários anos depois, passado o grande debate entre a Comunidade e os Espirituais que se distinguiam no pontificado de Clemente V (1305-1314 e João XXII (1316-1334), deu-se um fim à contenda jurídica em torno da pobreza absoluta de Cristo e dos apóstolos, ativando ao máximo a repressão e perseguição aos Espirituais.

\subsection{Os limites da pobreza normativa franciscana: dissidência e ortodoxia}

Conforme Lothar Hardick ${ }^{389}$, "a pobreza não é um conceito abstrato cujo sentido permaneceria imutável em todos os tempos e lugares. Assim como a riqueza, a pobreza depende das condições sociais e é, portanto, um valor relativo que só pode ser determinado em função das condições de vida econômico-sociais nos diferentes tempos e nos diversos povos". Sendo assim, existem muitas variações na concretização da pobreza ao longo da Idade Média. No entanto, a pobreza sempre esteve ligada mais ou menos a uma notável falta dos bens que são colocados à disposição de todos como propriedade, consumo ou meio de trabalho. O movimento da pobreza voluntária não é exclusividade do cristianismo e muito menos do franciscanismo, que não trouxe algo novo, mas resignificou algo já presente na doutrina cristã. Ademais, Francisco não foi o único entusiasta da pobreza no seu tempo, tivemos vários movimentos pauperísticos que foram considerados heréticos como os Pobres de Cristo, os cátaros, os Humilhados, os Valdenses, os Pobres Católicos e os Pobres Reconciliados.

Como bem salienta Michel Mollat ${ }^{390}$, com as Ordens Mendicantes do século XIII um novo olhar sobre os pobres foi lançado. Tanto para Francisco quanto para Domingos, a ideia de reintegrar os pobres na sociedade e partilhar com eles um gênero de vida pela máxima "ser um em meio aos pobres" não se trata de uma novidade no período. Portanto, Mollat nos recorda que todos os

\footnotetext{
${ }^{389}$ HARDICK, Lothar. "Pobreza, pobre". Op. cit., p. 586.

390 Cf. MOLLAT, Michel. Os pobres na Idade Média. Rio de Janeiro: Campus, 1989, pp. 115118.
} 
gestos de Francisco têm origem na massa volumosa de uma tradição de caridade cristã mais que milenar com referência diretamente ao Evangelho e passada pelos Atos dos Apóstolos. Mas a pobreza foi um fato concreto nas cidades e Francisco e Domingos tiveram originalidade na história da pobreza vivida, souberam dar atenção aos "sinais dos tempos", tratando das necessidades dos homens na época em que viviam e propondo um sentido de um Deus salvador e do homem pecador redimido. Francisco recusou as regras anteriores da vida monástica que a Igreja Romana lhe propunha para evitar o isolamento, combatendo pessoalmente o mal da avareza, orgulho e violência que ele identificava naquela sociedade. Para André Vauchez, Francisco de Assis seguia uma tradição cristã e ao mesmo tempo sintetizava as aspirações dos movimentos religiosos anteriores, mantendo obediência total à Igreja. A mensagem de Francisco era acessível a todos, a sua originalidade residiria na vontade de levar uma vida pobre e errante, a exemplo de Cristo, numa recusa à posse pessoal de bens, mas igualmente comunitária ${ }^{391}$.

Segundo os postulados de Michel Mollat, São Francisco ocupa um lugar na história da pobreza em que não é somente movido pela sua experiência vivida, idealizada e proposta no modelo de vida da Regra. Ele é, entre outras correntes da Idade média, um protesto, o mais repercutido sem dúvida, em nome dos excluídos daquela sociedade ${ }^{392}$.

Para as Ordens mendicantes, diante de uma sociedade onde o dinheiro tendia a aumentar o poder daqueles que o possuiam, o valor humano do pobre e a sua sacralização através do modelo de Cristo pobre emergiam na estima ao pobre e ao aflito por seu valor espiritual e humano próprio e não mais na qualidade de instrumento de salvação do rico. Francisco propôs um projeto de vida caracterizado pelo ideal de uma existência pobre, que preconizava a ausência de propriedade, a recusa de provisões, do dinheiro, dos cargos e do poder, bem como a disposição de viver de esmolas em favor de uma fraternidade equânime, universalmente pobre em bens materiais. Este modo de

391 VAUCHEZ, André. A espiritualidade da Idade Média Ocidental: séculos VIII-XIII. Lisboa: Estampa, 1995, pp. 142-143.

${ }^{392}$ MOLLAT, Michel. Pauvres et pauvreté dans le monde Médiéval. In: La povertà del secolo XII e Francesco D'Assisi. Atti del II Convegno internazionale. Assisi 17-19 ottobre 1974. Assis: Società internazionale di studi Francescani, 1975, p. 87. 
vida foi adaptando-se ao crescimento da fraternitas, portanto, esses elementos estão presentes na redação das Regras e do Testamento ${ }^{393}$.

A partir da análise das Regras e do Testamento de Francisco de Assis, constatamos que a pobreza franciscana permite várias interpretações. Pensando numa definição mais precisa do conceito de pobreza ${ }^{394}$ franciscana a partir do nosso corpus documental, partimos do" viver sem nada de próprio", que tem origem bíblica: por isso representou uma resignificação do movimento Franciscano da primeira geração menorita do seguinte trecho "Se queres ser perfeito, vai, vende o que possuis e dá aos pobres, e terás um tesouro nos céus. Depois, vem e segue-me." (Mt 19, 21). A "leitura" do trecho bíblico mencionado está presente na Regra nos Capítulos II e VI.

\begin{abstract}
... dicant illis verbum sancti Evangelii, quod vadant et vendant omnia sua et ea studeant pauperibus erogare" e "Fratres nihil sibi approprient nec domum nec locum nec aliquam rem. Et tanquam peregrini et advenae in hoc saeculo in paupertate et humilitate Domino famulantes vadant pro eleemosyna confidenter, nec oportet eos verecundari, quia Dominus pro nobis se fecit pauperem in hoc mundo. Haec est illa celsitudo altissimae paupertatis, quae vos, carissimos fratres meos, heredes et reges regni caelorum instituit, pauperes rebus fecit, virtutibus sublimavit. ${ }^{395}$.
\end{abstract}

No Testamento a pobreza aparece nas seguintes passagens também utilizadas nas Expositio dos frades em diferentes tempos.

\footnotetext{
393 "Appoggiandosi alla tradizione giuridica, i canonisti facevano della povertà un insieme di casistiche con le quali cercavano di conciliare lo 'spirito di povertà' con i possedimenti in comune, nella 'stabilitas loci' di un monastero o di una canonica, finendo spesso col mettere in maggiore evidenza, nella Chiesa, la duplice e paradossale tensione della povertà come scandalo sociale e come valore religioso al tempo stesso.". CAMPAGNOLA, Stanislao da. La povertà nelle 'regulae'..., p. 223.

394 Aqui, citamos, como obras de apoio e consulta, os seguintes verbetes dos dicionários especializados:

"Pauvreté". In: FÉDOU, René et alii. Lexique historique du Moyen Age. Paris: Armand Colin, 1995 (Cursus), pp. 119 e 120.

HARDICK, Lothar. "Povertà, povero". In: CAROLI, Ernesto (org.). Dizionario Francescano: Spiritualità. Padova: Messaggero di S. Antonio, 1995, pp. 1551-1588.

HARDICK, Lothar. "Pobreza, pobre". In: CAROLI, Ernesto (org.). Dicionário Franciscano. Petrópolis: Vozes, 1999, 586-599.

"Francisco de Assis, São". In: LOYN, Henry R. (org.). Dicionário da Idade Média. Trad. Álvaro Cabral. Rio de Janeiro: Zahar, 1991, pp. 157 e 158.

"Franciscains". In: NELLI, René. Dictionnaire du Catharisme et des Hérésies Meridionales. Toulouse: Privat, 1994.

The Catholic Encyclopedia: An International Work of Reference on the Constitution, Doctrine, Discipline and History of the Catholic Church. New York: The Universal Knowledge Foundation, Inc., 15 vol., 1913.

STRAYER, J. R. (ed.). Dictionary of the Middle Ages. New York, 13 vols., 1982-89.

395 Cf. Bíblia de Jerusalém. São Paulo: Paulus, 2008, p. 1739. Regula bullata, 2, 3 e 6, 2-5. MENESTÒ, Enrico \& BRUFANI, Stefano. Fontes Franciscani. Assis: Edizioni Porziuncola, 1995, pp. 172 e 176.
} 
Et illi qui veniebant ad recipiendam vitam, omnia quae habere poterant, dabant pauperibus; et erant contenti tunica una, intus et foris repeciata, cum cingulo et braccis. Et nolebamus plus habere. [...] Et quando non daretur nobis pretium laboris, recurramus ad mensam Domini, petendo eleemosynam ostiatim. [...] Caveant sibi fratres, ut ecclesias, habitacula paupercula et omnia, quae pro ipsis construuntur, penitus non recipiant, nisi essent, sicut decet sanctam paupertatem, quam in regula promisimus, semper ibi hospitantes sicut advenae et peregrini." ${ }^{396}$.

Todas essas passagens mencionadas do nosso corpus documental representam a base conceitual da pobreza do movimento Franciscano e das "leituras" a posteriori feitas tanto pelos frades quanto pelos papas. Retomaremos alguns pontos que foram discutidos ao longo da dissertação com o objetivo de encaminhamento para a conclusão.

Com efeito, a pobreza entre as Regulae distingue-se sutilmente em algumas partes. Na Regra de 1221, a pobreza tinha a forma sobretudo da renúncia dos bens, principalmente com a proibição de receber, na ocasião, "aliquam pecuniam, neque per se, neque per interpositam personam". A proibição de receber dinheiro era uma constante no ideal pauperístico de Francisco e companheiros, sempre reportando a uma tipologia ideal e idealizada de Cristo e dos Apostólos: Cristo que se "fez pobre por nós neste mundo" e, segundo a Regra de 1221, o não receber dinheiro parecia ir de acordo com a real utilidade prática que a pecúnia representava no período: "Quia non debemus maiorem utilitatem habere et reputare in pecunia et denariis quam in lapidibus", confirmada pela passagem em que se proibiu aos frades a intromissão nos "temporalibus negotiis" ou de receber dinheiro de postulantes no ato da expropriação dos seus bens. Os frades itinerantes que excerciam uma profissão artesanal podiam ter "ferramenta et instrumenta suis artibus necessari", mas ninguém podia "ubicumque sit et quocumque vadit, aliquo modo tollat, nec recipiat, nec recipi faciat pecuniam aut denarios, nec occasione vestimentorum, nec librorum, nec pro pretio alicuius laboris, immo nulla occasione, nisi propter manifestam necessitatem infirmorum fratrum". A restrição "excepta solummodo praedicta infirmorum necessitate" desaparece na

\footnotetext{
${ }^{396}$ Testamentum, 16, 17 e 24. MENESTÒ, Enrico \& BRUFANI, Stefano. Fontes Franciscani.
} Assis: Edizioni Porziuncola, 1995, pp. 229 e 230. 
norma de 1223; é a única anomalia que, em matéria de dinheiro, podemos encontrar.

Sem dúvida, verifica-se que a recusa em receber dinheiro no sentido de apropriação e não possuir alguma coisa temporal exprimem o núcleo fundamental da realidade pauperística franciscana que mesmo com as diferenças entre as duas normativas, ainda assim permanecem esses pontos em comum sobre a questão de "apropriação" ou de "posse", que não impedia o "uso" das coisas, por isso discordamos de Theophile Desbonnets que menciona essa passagem da Ordo para a fraternitas como uma passagem "não tão natural". Não existe passagem natural para o movimento Franciscano em nada, porque isso implicaria que os episódios da história do franciscanismo seriam algo dado e pronto, diminuindo os aspectos conflitantes, de tensões, de complexidade e, sobretudo, os modelos cristalizados pelas hagiografias contribuem menos ainda para o entendimento das representações da pobreza radical que foram marginalizadas pela instituição e pela Igreja.

A economia da pobreza franciscana não precedia a possessão de algum bem temporal, fundamentada sobre o exercício de uma atividade que fosse suficientemente recompensada para manter uma alimentação quotidiana, a vestimenta, o uso e a manutenção dos instrumentos de trabalho, ou seja, era permitido receber as coisas "necessarie al corpo". O problema das Regulae é que não existia uma definição aplicável tão clara ou fechada do que seria a "necessarie al corpo" ou a "altissimae paupertatis", o que acarretava controvérsias sobre a prática no quotidiano dos conventos. Deste modo multiplicavam-se as discussões inacabavéis no interior da Ordem, que culminaram com a crise institucional do início do século XIV e com a negação do paradigma de pobreza franciscana pelo papa João XXII em 1323.

Além disso, um ponto bastante importante segundo Stanislao da Campagnola $^{397}$ com o qual concordamos é que nem as interpretações da "Comunidade", nem as interpretações dos "Espirituais" chegaram a subtrair a sedução que o ideal monástico continuava a fomentar nas práxis e na organização da vida pauperística associada. Para Raoul Manselli ${ }^{398}$, Francisco

\footnotetext{
${ }^{397}$ CAMPAGNOLA, Stanislao da. Op. cit., p. 253.

398 MANSELLI, Raoul. La povertà nella vita di Francesco d'Assisi. In: La povertà del secolo XII e Francesco d'Assisi. Atti del II Convegno Internazionale. Assisi, 18-20 ottobre 1974. Società
} 
de Assis "é colocado como exemplo de vida cristã do seu século, com uma vontade tal que ainda hoje constitui uma pedra angular e um estímulo que se faz sentir nas direções, nos tempos e nas formas mais diferentes. Por isso o sentido da sua vida, do seu modo de viver a pobreza, não da maneira abstrata de adesão à uma forma jurídica, mas como libertação suprema de cada laço, sobrecarregada e embrutecida da pessoa humana. Na biografia de Francisco existe uma exemplaridade que vai para além de cada particular, para elevar-se ao eterno". Ou seja, Francisco foi um ícone importante para além do tempo em que ele vivia, não somente porque teve uma popularidade estimulada pela Igreja romana, mas sobretudo porque a sua proposta de vida evangélica foi um modelo apropriado por diversos pensadores cristãos ou não, que elegeram o exemplum do pobre de Assis como um grito aos excluídos ao longo dos séculos e que se faz sentir nos dias atuais se pensarmos nos vários movimentos sociais da atualidade.

Enfim, nas contendas jurídicas que se formaram em torno da pobreza normativa tivemos a criação de muitos conceitos que foram importantes, como a proprietas e dominium, sendo traduzidos como propriedade, o que não corresponde ao mesmo significado das Regras e do Testamento. Porque o conceito de propriedade do nosso corpus documental não é um conceito jurídico fechado, assim como a distinção entre propriedade e uso não nos parece ter sido percebida por Francisco e seus companheiros.

Isso também sucedeu com os conceitos derivados de sutilezas jurídicas formuladas pelos papas, como o uso cômodo e útil (commoda fratrum), uso moderado (usus moderatus), usufruto (ususfructus), direito de uso (ius utendi), uso simples (simplex usus), uso simples de fato (simplex usus facti) e uso pobre (usus pauper). Todos eles foram criados para atender às exigências da institucionalização da Ordem, os projetos diversos dos papas para a Ordem e os objetivos práticos da aplicabilidade da "lex fundamentalis", o que provocou controvérsias sobre a pobreza no interior do movimento Franciscano. Daí resultaram as diversas Expositio dos Frades menores em diferentes tempos, correspondendo às inúmeras tentativas de interpretar a pobreza cristalizada na Regra sob a luz de uma verdadeira intentio de

internazionale di studi francescani. Spoleto: Centro interuniversitário dei studi francescani, Centro italiano di studi sull'Alto medioevo,1975, p. 282. 
Francisco. Essa intentio de Francisco era determinada pela Igreja romana e pelos altos escalões da Ordem dos Menores, que definia, entre outras coisas, os frades "dissidentes" e os frades dentro da ortodoxia. A ortodoxia nem sempre era fechada, ora tendia para o lado dos frades da "Comunidade", ora tendia para o lado dos "Espirituais", definições que pareciam claras num determinado momento; em outros eram heréticas e errôneas.

Enfim, o limite entre ser franciscano e dissidente do movimento era bastante tênue, o que não pode ser confundido com heresia, porque tanto Boaventura quanto Angelo Clareno ou Pedro Olivi estavam de acordo com a Regra e o Testamento de São Francisco. O que sempre houve e há são "leituras" da representação de pobreza franciscana de Francisco e da Regra que podiam ou podem estar dentro ou fora da institucionalidade, mas as práticas devocionais constituem uma dinâmica bastante complexa que vai além das divisões da Ordem e dos modelos representativos de frades. Em suma, o caráter de universalidade de Francisco vai além do modelo de canonização consagrado em 1228. 


\section{CONSIDERAÇÕES FINAIS}

As considerações finais que exporemos aqui não têm como objetivo esgotar o tema ou encerrar este trabalho. Ao contrário, enumeramos uma série de observações ponderadas com base na análise que fizemos resultantes do estudo pormenorizado do nosso corpus documental e do debate historiográfico imbricados ao longo desta dissertação.

A pobreza franciscana reparte-se em muitos caminhos. Antes de tudo, Francisco de Assis representa um ícone que vai além da santidade cristalizada pela Igreja, presente na religiosidade popular do medievo. Foi uma das figuras mais importantes do século XIII. Sem dúvida, é impossível pensar a pobreza na Idade Média sem pensar automaticamente em Francisco e seu movimento. A fraternitas criada por ele era um estado de espírito ou um ideal num grau elevado de abstração numa época em que a burguesia emergente dominava o ambiente citadino. Nas Regulae e no Testamentum de Francisco de Assis oriundo e renegado desta burguesia - não há uma definição de maneira absoluta do sentido da palavra pobreza, implicando ela própria em ideal e estado de espírito; então, os seguidores fizeram dela inúmeras leituras diferentes.

Neste estudo, procuramos demonstrar o processo de construção da norma no movimento Franciscano a partir da proto-Regra de 1210, da Regula non bullata de 1221, da Regula bullata de 1223 e do Testamentum beati Francisci de 1226. Assim como seu fundador, o movimento Franciscano nasceu laico e desde os seus primeiros seguidores foi inserido paulatinamente na obediência à Igreja por meio de um cardeal protetor antes mesmo da redação definitiva da Norma.

Como apresentamos, a Regra bulada de 1223 derivou da Regra não bulada de 1221, que se adaptou aos preceitos canônicos do Corpus Juris Canonici e do IV Concílio de Latrão de 1215. Desta forma, a Regra é o principal documento fundador da Ordem Franciscana, representa não apenas a "lex fundamentalis" do compromisso espiritual de uma Ordem mendicante, bem como foi o ponto de partida para a construção dos demais registros da Ordem 
franciscana no medievo. As Regras e o Testamento são frutos do mesmo espírito e da mesma instituição; apesar da autoria das fontes serem atribuídas a Francisco de Assis, o nosso corpus documental resulta do trabalho de um grupo ou coletivo heterogêneo. A diferença entre as nossas fontes abordadas está no gênero retórico e na finalidade ou natureza de cada um, mas a essência é a mesma conforme evidenciamos no capítulo um desta dissertação.

Como afirmamos e demonstramos, o conceito de pobreza na Regra dos Frades menores não é um conceito fechado; ele permite vários caminhos interpretativos. Ao longo dos séculos XIII e XIV suscitou muitas dúvidas com relação à sua aplicação no cotidiano dos conventos. Colocar em prática a codificação era o principal motivo de tensão do movimento Franciscano, que tentava adequar-se às prescrições da institucionalização imposta pela Igreja romana e pelo próprio crescimento e desenvolvimento burocrático da Ordem. Justamente por ser um registro enxuto e conciso, a Regra porta uma explicação jurídica fechada do princípio de "não ter propriedades", nem em coletivo nem individual, consequentemente tivemos muitas constituições papais com o intuito de trazer alguma aplicabilidade da Norma à medida que as dificuldades internas da Ordem demandavam uma solução de um agente "externo", o papa, a autoridade máxima da Igreja. Outra controvérsia que fazia parte de um dos problemas dos Menores era a incerteza do valor jurídico do Testamento, que por diversas vezes foi negado pela Cúria romana, mas continuou a perpetuar-se no imaginário da maioria dos frades como um documento de obrigatória observância junto à Regra de 1223.

Por meio de sutilezas jurídicas, os papas foram tentando resolver os problemas internos disciplinares e de organização de uma Ordem que, recém criada, diferenciava-se das demais Ordens religiosas pelo caráter específico da sua normativa apostólica. Também ao longo da história da Ordem, constatamos que o ministro geral e os ministros provinciais participavam ativamente da construção da identidade franciscana e organização do movimento Franciscano que teve diferentes papéis atribuídos pelos papas no período que analisamos nesta dissertação. Além disso, como vimos, a interferência da Igreja não visava a alterar o espírito franciscano como apregoam alguns historiadores, mas enquadrá-lo nos moldes das instituições monásticas tradicionais, preservando-lhe as características específicas que 
sofreriam metamorfoses ao longo da construção normativa para a adaptação de acordo com o Corpus Juris canonici. Em resumo, o problema jurídico aqui foi a adaptação de um movimento popular e seu adequamento aos padrões legislativos da Igreja do medievo. A pobreza só poderia ser aquela que era comum aos outros grupos religiosos que estavam dentro da ortodoxia. Sem dúvida, uma das consequências disso tudo foi a pobreza prática abortada em quase todos os momentos, para uma pobreza cada vez mais restrita ao plano teórico e centralizada na instituição; por isso tantas tensões na interpretação da norma.

Enfim, o estudo das Regras e do Testamento nos permitiu aprofundar a questão jurídica da pobreza franciscana do primeiro século de fundação da Ordem dos Menores e as consequências das suas primeiras práticas legislativas de organização que influenciaram a relação da Igreja com o movimento e do movimento para com outras Ordens religiosas na busca de participação na cristandade latina.

Em suma, na evolução das discussões jurídicas que se formaram acerca da pobreza normativa demonstramos as contribuições do direito civil romano como a proprietas e dominium, traduzidos como propriedade, destoando do significado da pobreza não jurídica das Regras e Testamento. Por isso, afirmamos que o conceito de propriedade do nosso corpus documental não é um conceito jurídico fechado, apesar de assim aparentar; a distinção entre propriedade e uso não nos parece ter sido tão bem percebida pela primeira geração menorita.

O enriquecimento do debate em torno da dinâmica normativa franciscana desdobrou-se em conceitos exemplificados no capítulo dois, a saber, uso cômodo e útil (commoda fratrum), uso moderado (usus moderatus), usufruto (ususfructus), direito de uso (ius utendi), uso simples (simplex usus), uso simples de fato (simplex usus facti) e uso pobre (usus pauper). Como já mencionamos anteriormente, todos eles foram criados para atender às exigências da institucionalização da Ordem e aos objetivos práticos da aplicabilidade da "lex fundamentalis", o que gerou controvérsias sobre a pobrezada no interior do movimento Franciscano. Fruto disso, são as diversas Expositio dos Frades menores em diferentes tempos, que não passavam de tentativas de aplicação e de interpretação da pobreza normativa e de reviver no 
presente a fraternitas, com o intuito de definir a verdadeira intentio de Francisco. Talvez essa verdadeira intenção de Francisco de Assis nunca saberemos ao certo o que era, pois ele acabou virando um ícone esfumaçado pelas diversas correntes formadas no interior da Ordem, bem como teve sua imagem e sua vida apropriadas por muitos pensadores cristãos e não cristãos, justamente por causa dos eternos debates sobre o direito da propriedade. 


\section{BIBLIOGRAFIA}

\section{Fontes}

- ANGelo ClARENO. Expositio super Regulam Fratrum Minorum. Aos cuidados de Pe. Giovanni Boccali, O.F.M.; intr. Felice Accrocca; trad. Ital. Pe. Marino Bigarone, O.F.M. Santa Maria degli Angeli: Edizioni Porziuncula, 1994.

- Apologia pauperum contra calumniatorem. In: Obras de San Buenaventura. Edicion bilingue. Madrid: Pontificia Universidad de Salamanca, La Editorial Catolica, 1949.

- BAZAGLIA, Paulo (direção). Bíblia de Jerusalém. São Paulo: Paulus, 2008.

- CAROLI, Ernesto (org.) Fonti Francescane, nuova edizione. Scritti e biografie di san Francesco d'Assisi. Cronache e altre testimonianze Del primo secolo francescano. Scritti e biografie di santa Chiara d'Assisi. Testi normativi dell'Ordine Francescano Secolare. Padova: Editrici Francescane, 2004.

- FOREVILLE, Raymonde. Latran I, II, III et Latran IV. Paris: Éditions de L'Orante, 1965.

- HEFELE, Charles-Joseph. Histoire des Conciles: d'apres les documents originaux. Deuxieme partie. Paris: Letouzey et Ané, Editeurs, 1913.

- MENESTÒ, Enrico e BRUFANI, Stefano. Fontes franciscani. Assis: Edizione Porziuncola, 1995.

- ROBAERT, Plácido \& FASSINI, Dorvalino (org. e trad.). Exposição sobre a Regra dos Frades menores. São Boaventura. Porto Alegre: Evangraf, 2008. 
- TEIXEIRA, Celso Márcio (org.). Fontes Franciscanas e Clarianas. Petrópolis: Vozes, 2ª edição, 2008.

\section{Obras de referência}

- AUW, Lydia von. "Angelo Clareno et les spirituels du Midi". In: Franciscains d'Oc. Les Spirituels ca 1280-1324. Toulouse: Cahiers de Fanjeaux, Privat Editeur et Centre d'Etudes historiques de Fanjeaux, 1975, pp. 243-262.

"À propos d'Angelo Clareno". In: Chi erano gli spirituali. Atti del III Convegno Internazionale. Assisi, 16-18 ottobre 1975. Assisi: Società Internazionale di Studi Francescani, 1976, pp. 205-220.

- BARONE, Giulia. Frate Elia: suggestioni da una rilettura. In: I compagni di Francesco e la prima generazione minoritica. Atti del XIX Convegno internazionale, Assisi, 17-19 ottobre 1991. Espoleto: Centro Italiano di studi sull'alto medioevo, 1992, pp. 59-80.

- BARRACLOUGH, Geoffrey. Papas na Idade Média. Lisboa: Verbo, 1972.

- BOFF, Leonardo. Igreja, carisma e poder: ensaios de eclesiologia militante. Petrópolis: Vozes, 1982.

- BOLTON, Brenda. A Reforma na Idade Média século XII. Lisboa: Edições 70, 1983.

- BURGAUX, Ch. Histoire des Papes. Versaliis: Persan, 1949.

- BURR, David. The Spiritual Franciscans. From protest to Persecution in the century after Saint Francis. Pennsylvania: The Pennsylvania State University Press, 2001. 
- CAMPAGNOLA, Stanislao da. La povertà nelle "Regulae" di Francesco d'Assisi. In: La povertà del secolo XII e Francesco d'Assisi. Assis: Atti del II Convegno Internazionale, 1975, pp.

. Le origini franciscane come problema storiografico. Perúgia: universitá degli Studi di Perugia, 1979.

- CARVALHO, Cibele. Francisco de Assis entre duas Regras (1221-1223). Dissertação de Mestrado. Curitiba: Universidade Federal do Paraná, 2005.

- CASAGRANDE, Giovanna. Un Ordine per i laici. Penitenza e Penitenti nel Duecento. In: MERLO, Grado Giovanni et al. Francesco d'Assisi e il primo secolo di storia francescana. Torino: Einaudi, 1997.

- CONTI, Martino. Estudos e pesquisas sobre o franciscanismo das Origens. Petrópolis: Vozes, 2004.

- DE BONI, Luis Alberto. De Abelardo a Lutero. Estudos sobre filosofia prática na Idade Média. Porto Alegre: EDIPUCRS, 2003.

- DESBONNETS, Theophile. Da intuição à instituição. Petrópolis: Vozes, 1987.

- DOLCINI, Carlo. Francesco d'Assisi e la storiografia degli ultimi vent'anni: problemi di metodo. In: Frate Francesco d'Assisi. Atti del XXI Convegno internazionale, Assisi, 14-16 ottobre 1993. Spoleto: Centro italiano di studi sull'alto Medioevo, 1994.

- ENGLEBERT, Omer. Vie de Saint François d'Assise. Paris: Albin Michel, 1982.

- ESSER, Kajetan. As origens e o espírito primitivo da Ordem dos Frades Menores. Petrópolis: Vozes, 1972.

- FALBEL, Nachman. Heresias medievais. São Paulo: Perspectiva, 1976. 
Os Espirituais Franciscanos, São Paulo: EDUSP,

FAPESP, Perspectiva, 1995.

- FLOOD, David. Frei Francisco e o Movimento Franciscano. Petrópolis: Vozes, 1986.

. "Pierre Jean-Olivi et la Règle Franciscaine". In: Franciscains d'Oc. Les Spirituels ca 1280-1324. Toulouse: Cahiers de Fanjeaux, Privat Editeur et Centre d'Etudes historiques de Fanjeaux, 1975, pp. 139-154.

- GRUNDMANN, Herbert. Religious movements in the middle ages. London: University of Notre Dame Press, 1995.

- LAMBERT, Malcolm D. Povertà Francescana. La dottrina dell'assoluta povertà di Cristo e degli Apostoli nell'Ordine Francescano (1210-1323). Milano: Edizioni Biblioteca Francescana, 1995.

- LAMBERTINI, Roberto. Momenti della formazione dell'identità francescana nel contesto della disputa con i secolari (1255-1279). In: Dalla "sequela Christi" di Francesco d'Assisi all'apologia della povertà. Atti del XVIII Convegno Internazionale. Assisi, 18-20 ottobre 1990. Espoleto: Centro italiano di studi sull'alto medioevo, 1992, pp. 123-172.

- LE GOFF, Jacques. As Ordens Mendicantes. In: BERLIOZ, Jacques. Monges e Religiosos na Idade Média. Lisboa: Terramar, 1994. As raízes medievais da Europa. Petrópolis: vozes, 2007. São Francisco de Assis. Rio de Janeiro: Record, 2001.

- MAALOUF, Amin. As cruzadas vistas pelos árabes. São Paulo: brasiliense, 2001. 
- MAGALHÃES, Ana Paula Tavares. Aspectos relacionados ao estabelecimento da Ordem Franciscana em Portugal: séculos XIII e XIV. In: MEGIANI, Ana Paula Torres \& SAMPAIO, Jorge Pereira de. (Org.). Inês de Castro: a época e a memória. 1 ed. São Paulo: Alameda, 2008, v. 1, pp. 59-78. . Contribuição à questão da pobreza presente na obra Arbor Vitae Crucifixae lesu, de Ubertino de Casale. Tese de Doutorado. São Paulo: Universidade de São Paulo, 2004.

. Entre a ermida e a cidade: dilemas da Ordem Franciscana entre os séculos XIII e XIV. [no prelo].

- MANSELLI, Raoul. La povertà nella vita di Francesco d'Assisi. In: La povertà del secolo XII e Francesco d'Assisi. Atti del II Convegno Internazionale. Assisi, 18-20 ottobre 1974. Società internazionale di studi francescani. Spoleto: Centro interuniversitário dei studi francescani, Centro italiano di studi sull'Alto medioevo,1975, pp. 255-282.

. "L'idéal du Spirituel". In: Franciscains d'Oc. Les Spirituels

ca 1280-1324. Toulouse: Cahiers de Fanjeaux, Privat Editeur et Centre d'Etudes historiques de Fanjeaux, 1975, pp. 99-126.

. São Francisco. Petrópolis: Vozes,1997.

- MARANESI, Pietro. I commenti alla Regola francescana e la questione dello studio. In: Studio e Studia: Le scuole degli ordini mendicanti tra XIII e XIV secolo. Atti del XXIX Convegno internazionale. Assisi, 11-13 ottobre 2001. Espoleto: Centro italiano di studi sull'Alto medioevo, 2002, pp. 33-81.

- MENESTÒ, Enrico. Leone e i compagni di Assisi. In: I compagni di Francesco e la prima generazione minoritica. Atti del XIX Convegno internazionale, Assisi, 17-19 ottobre 1991. Espoleto: Centro Italiano di studi sull'alto medioevo, 1992, pp. 31-58. 
- MERLO, Grado Giovanni. Em nome de São Francisco. História dos Frades Menores e do franciscanismo até inícios do século XVI. Trad. Ary E. Pintarelli. Petrópolis: Vozes/FFB, 2005.

- Intorno a Frate Francesco. In: I compagni di Francesco e la prima generazione minoritica. Atti del XIX Convegno Internazionale, Assisi, 17-19 ottobre, 1991. Spoleto: Centro Italiano di Studi Sull'Alto Medioevo, 1992.

- MICCOLI, Giovanni. Francisco de Assis: Realidade e memória de uma experiência cristã. Petrópolis: Vozes, 2004.

. Un'esperienza cristiana tra Vangelo e istituzione. In:

Dalla 'sequela Christi' di Francesco D'Assisi all'apologia della povertà. Atti del XVIII Convegno internazionale. Assisi, 18-20 ottobre 1990. Espoleto: Centro italiano di studi sull'alto medioevo, 1992, pp. 3-40.

- MOLLAT, Michel. Os pobres na Idade Média. Rio de Janeiro: Campus, 1989. Pauvres et pauvreté dans le monde Médiéval. In: La povertà del secolo XII e Francesco D'Assisi. Atti del II Convegno internazionale. Assisi 17-19 ottobre 1974. Assis: Società internazionale di studi Francescani, 1975, pp. 79-97.

- MOORMAN, John. L'espanzione Francescana dal 1216 al 1226. In: Francesco d'Assisi e francescanesimo dal 1216 al 1226. Espoleto: Atti della Società Internazionale di studi francescani, 1977, pp. 265-277.

- MUZZARELLI, Maria Giuseppina. Teorie e forme di penitenza in fase di transizione (secoli XI-XIII). In: CAPITANI, Ovidio et al. Dalla penitenza all'ascolto delle confessioni: il ruolo dei Frati Mendicanti. Atti del XXIII Convegno internazionale. Espoleto: Centro italiano di studi sull'alto Medioevo, 1996. 
- PAOLAZZI, Carlo. Lettura degli "Scritti" di Francesco d'Assisi. Milano: Edizioni Biblioteca Francescana, 2002.

- PÁSZTOR, Edith. Francesco d'Assisi e la "questione francescana". Assis: edizioni Porziuncola, 2000.

. La fraternità di Francesco e Tommaso da Celano. In: I compagni di Francesco e la prima generazione minoritica. Atti del XIX Convegno internazionale, Assisi, 17-19 ottobre 1991. Spoleto: Centro Italiano di Studi sull'alto Medioevo, 1992, pp. 81-118. "L'immagine di Cristo negli Spirituali". In: Chi erano gli spirituali. Atti del III Convegno Internazionale. Assisi, 16-18 ottobre 1975. Assisi: Società Internazionale di Studi Francescani, 1976, pp. 107-124.

- PELLEGRINI, Luigi. Storia e Geografia del 'reclutamento' francescano. In: I compagni di Francesco e la prima generazione minoritica. Atti del XIX Convegno internazionale, Assisi, 17-19 ottobre 1991. Espoleto: Centro Italiano di studi sull'alto medioevo, 1992, pp. 3-29.

- RAPP, Francis. L'Église et la vie religieuse en occident a la fin du Moyen Age. Paris: Presses Universitaires de France,1971.

- ROSSETTI, Felice. I genitori dei San Francesco. Città di Castello: edizioni il leccio, 1992.

- RUIZ, Carlos Mateo Martínez. Pedro de Juan Olivi. Opúsculos. Córdoba: Editorial de la Universidad Católica de Córdoba, 2005.

- SABATIER, Paul. Vida de São Francisco de Assis. Bragança Paulista: Editora universitária de São Francisco, Instituto Franciscano de Antropologia, 2006.

- Scivoletto, Nino. Problemi di língua e di stile degli scritti latini di san Francesco. In: Francesco d'Assisi e francescanesimo dal 1216 al 1226. Assisi, 
15-17 ottobre 1976. Atti della Società Internazionale di Studi francescani. Assis: Centro interuniversitario di studi francescani , 1977, volume IV, pp. 101-124.

- SENSI, Mario. Il perdono di Assisi. Assisi: edizioni porziuncola, 2002.

- TABARRONI, Andrea. La regola francescana. In: Dalla "sequela Christi" di Francesco d'Assisi all'apologia della povertà. Atti del XVIII Convegno Internazionale. Assisi, 18-20 ottobre 1990. Espoleto: Centro italiano di studi sull'alto medioevo, 1992, pp. 79-122.

- URIBE, Fernando. Apuntes para una lectura actualizada de la Regla Franciscana. Provincia Franciscana de Valencia, Aragón y Baleares: selecciones de Franciscanismo, 2006, volume 36, número 104, pp. 181-206.

"La 'pre-historia' de la Regla Franciscana". In: LAVILLA (org.), Miguel Ángel. Selecciones de Franciscanismo. Valencia: 2010, 115, volume XXXIX, fasc. 1, pp. 3-35.

Por los caminos de Francisco de Asis. Oñate: Franciscana Aránzazu, 1990.

- VAN DIJK, Willibrord-Christian. La représentation de Saint François D'Assise dans les Écrits des Spirituels. In: Franciscains d'Oc. Les Spirituels ca 12801324. Toulouse: Cahiers de Fanjeaux, Privat, Editeur, et Centre d'Etudes historiques de Fanjeaux, 1975, pp. 203-230.

- VAUCHEZ, André. A espiritualidade da Idade Média Ocidental: século VIIIXIII. Lisboa: Estampa, 1995.

. François d'Assise. Entre histoire et mémoire. Paris: Fayard, 2009.

São Domingos, "o mal-amado". In: BERLIOZ, Jacques. Monges e religiosos na Idade Média. Lisboa: Terramar, 1994, pp. 30-48. 


\section{Dicionários e Enciclopédias}

- ALLEGREZZA, Franca. Niccolò III. In: ENCICLOPEDIA dei Papi. Roma: Istituto della Enciclopedia italiana, 2000, 2v, pp. 437-446.

- BAGLIANI, Agostino Paravicini. Clemente V. In: ENCICLOPEDIA dei Papi. Roma: Istituto della Enciclopedia italiana, 2000, 2v, pp. 501-512.

Innocenzo IV. In: ENCICLOPEDIA dei Papi.

Roma: Istituto della Enciclopedia italiana, 2000, 2v, pp. 384-393.

- BASETTI-SANI, Giulio. Sarracenos. In: CAROLI, Ernesto (Org.). Dicionário Franciscano. Petrópolis: Vozes, 1999, pp. 691-700.

- CAPITANI, Ovidio. Gregorio IX. In: ENCICLOPÉDIA dei Papi. Roma: Istituto della Enciclopedia italiana, 2000, 2v, pp. 363-380.

- CASAGRANDE, Carla \& VECCHIO, Silvana. Pecado. In: LE GOFF, Jacques e SCHIMIDT, Jean-Claude. Dicionário Temático do Ocidente Medieval. Coord. Da trad. Hilário Franco Jr. Bauru: EDUSC; São Paulo: Imprensa Oficial do Estado, 2002, 2 v., pp. 337-351.

- CONTI, Martino. Regra, monaquismo. In: CAROLI, Ernesto (org.) Dicionário franciscano. Petrópolis: Vozes, 1999, pp.639-653.

. Testamento de São Francisco. In: CAROLI, Ernesto (org.) Dicionário franciscano. Petrópolis: Vozes, 1999, pp. 740-747.

-. FÉDOU, René et alii. Lexique historique du Moyen Age. Paris: Armand Colin, 1995 (Cursus). 
- HARDICK, Lothar. Povertà, povero. In: CAROLI, Ernesto (org.). Dizionario Francescano: Spiritualità. Padova: Messaggero di S. Antonio, 1995, pp. 15511588.

. Pobreza, pobre. In: CAROLI, Ernesto (org.). Dicionário Franciscano. Petrópolis: Vozes, 1999, 586-599.

- IOGNA-PRAT, Dominique. Ordem. In: LE GOFF, Jacques e SCHIMIDT, JeanClaude. Dicionário Temático do Ocidente Medieval. Coord. Da trad. Hilário Franco Jr. Bauru: EDUSC; São Paulo: Imprensa Oficial do Estado, 2002, 2v., pp. 305-319.

- LOYN, Henry R. (org.). Dicionário da Idade Média. Trad. Álvaro Cabral. Rio de Janeiro: Zahar, 1991.

- MALECZEK, Werner. Innocenzo III. In: ENCICLOPÉDIA dei Papi. Roma: Istituto della Enciclopedia italiana, 2000, 2 v, pp. 326-350.

- NELLI, René. Dictionnaire du Catharisme et des Hérésies Meridionales. Toulouse: Privat, 1994.

- PAZZELLI, Raffaelle. Penitência, mortificação. In: CAROLI, Ernesto (Org.). Dicionário Franciscano. Petrópolis: Vozes, 1999, pp. 551-559.

- STRAYER, J. R. (ed.). Dictionary of the Middle Ages. New York, 13 vols., 1982-89.

- The Catholic Encyclopedia: An International Work of Reference on the Constitution, Doctrine, Discipline and History of the Catholic Church. New York: The Universal Knowledge Foundation, Inc., 15 vol., 1913.

- TROTTMANN, Christian. Giovanni XXII. In: ENCICLOPEDIA dei Papi. Roma: Istituto della Enciclopedia italiana, 2000, 2v, pp. 512-522. 
- VENDITTELLI, Sandro Carocci-Marco. Onorio III. In: ENCICLOPEDIA dei Papi. Roma: Istituto della Enciclopedia italiana, 2000, 2v, pp. 350-362.

- VORREUX, Damien. Tau. In: CAROLI, Ernesto. Dicionário Franciscano. Petrópolis: Vozes, 1999, pp. 724-727.

\section{Páginas eletrônicas}

- Bula "Ad conditorem canonum" de 8 de dezembro de 1322 de João XXII. Disponível em: <http://www.humanities.mq.edu.au/Ockham/wadc.html> Acesso em: 20 Agos. 2010.

- Bula "Exiit qui seminat" de 14 de agosto de 1279 de Nicolau III, tradução espanhola dos frades franciscanos del Sur, disponível em <http://www.franciscanos.net/document/exiit.htm> Acesso em: 20 agos. 2009.

- Bula "Sicut phialae aureae" de 9 de julho de 1228 de Gregório IX. Disponível em: <http://www.wikitau.org/index.php5/Sicut_phialae_aureae> Acesso em: 30 Maio 2010.

DOCUMENTA CATHOLICA OMNIA. Disponível em: http://www.documentacatholicaomnia.eu/. Acesso em 01 dez. 2009.

- JSTOR. Sistema online de arquivamento de periódicos acadêmicos. Disponível em: http://www.jstor.org/. Acesso em 01 dez. 2009.

- MAGALHÃES, Ana Paula Tavares. "A trajetória e a obra de Pedro de João Olivi (c. 1248-1298): fundamentos para a elaboração do pensamento franciscano". Scintilla: Revista de Filosofia e Mística Medieval. Curitiba, vol. 4, n. 2, 2007, pp. 75-108.

Disponível em: <http://www.saoboaventura.edu.br/pdf/scintillavol4n2.pdf>. Acesso em: 15 jan. 2010. 
- MUSCAT, Noel. History of the Franciscan Movement. From the beginnings of the Order to the year 1517. Jerusalém: 2008, p. 14. Disponível em: <http://www.franciscan-sfo.org/hland/histfranmov1.pdf> Acesso em: 20 Agos. 2010.

- PROCASP. Província dos Capuchinhos de São Paulo. Disponível em: http://www.procasp.org.br/. Acesso em: 01 dez. 2009.

- STANFORD ENCYCLOPEDIA OF PHILOSOPHY. Disponível em: http://plato.stanford.edu/entries/. Acesso em: 01 dez. 2009;

- THE FRANCISCAN ARCHIVE. Disponível em: http://www.franciscanarchive.org/index2.html. Acesso em: 01 dez. 2009. 


\section{Mapa 1}

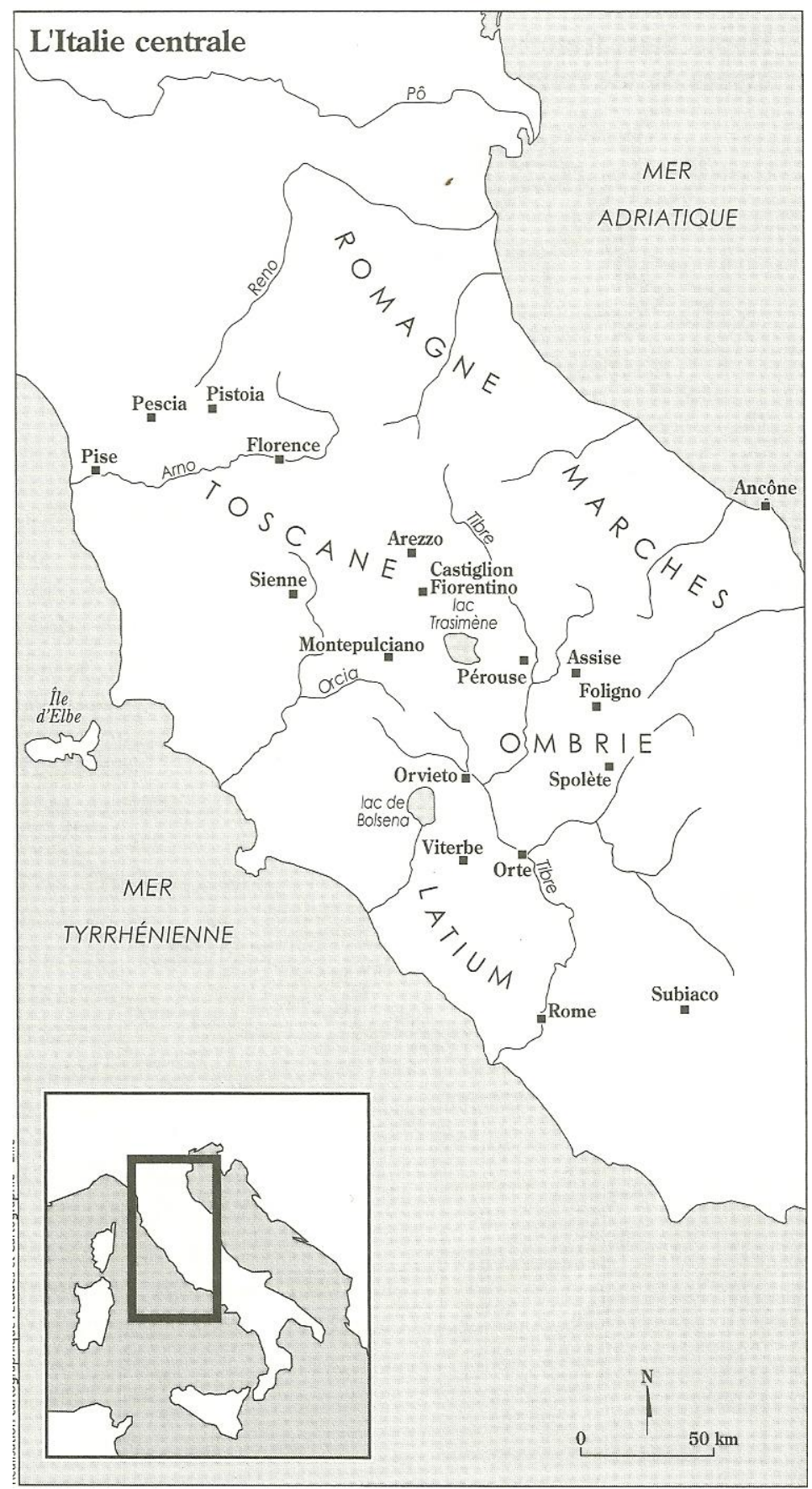

Fonte: VAUCHEZ, André. François d'Assise. Entre histoire et mémoire. Paris: Fayard, 2009, p.533. 


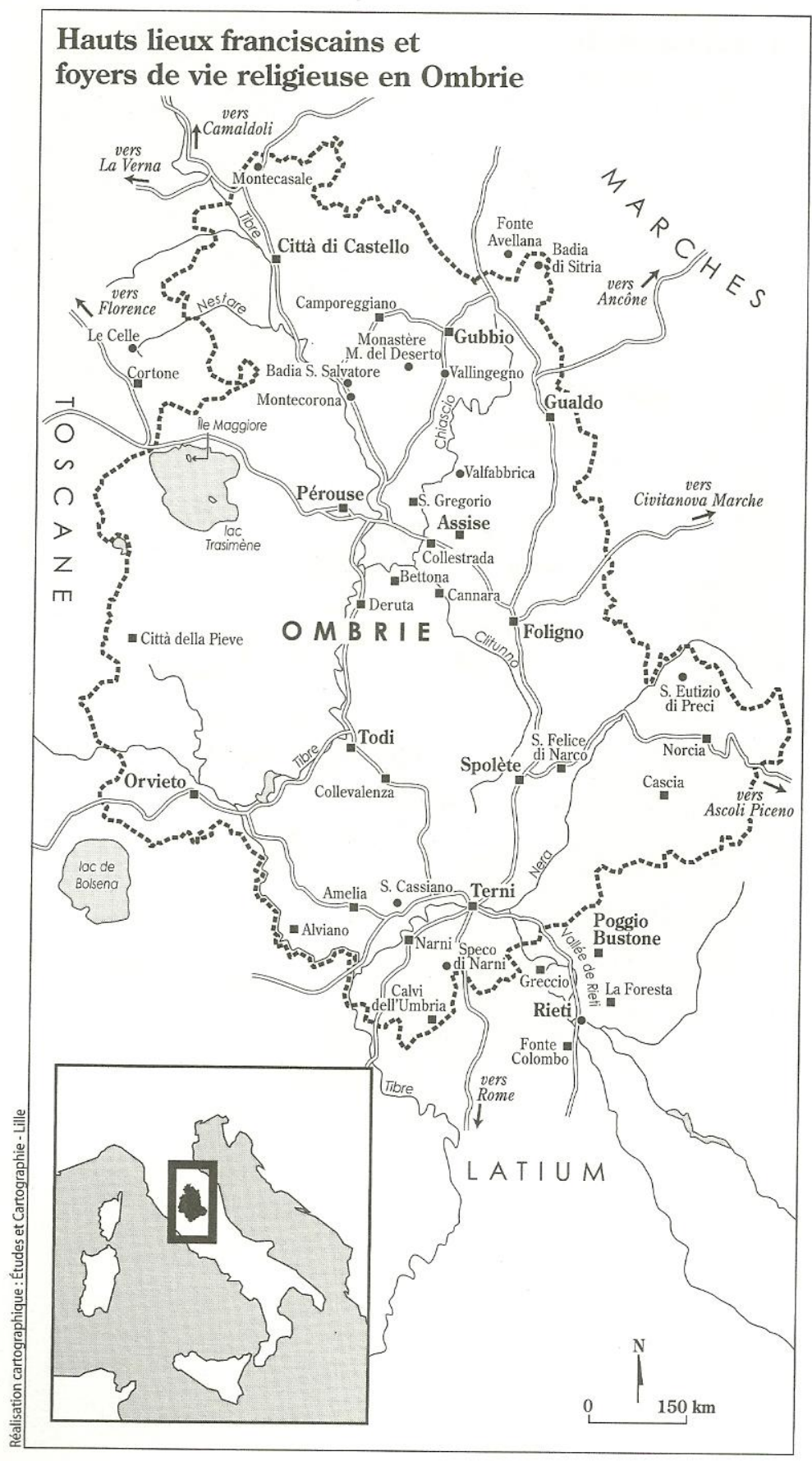

Fonte: VAUCHEZ, André. François d'Assise. Entre histoire et mémoire. Paris: Fayard, 2009, p.534. 
Mapa 3

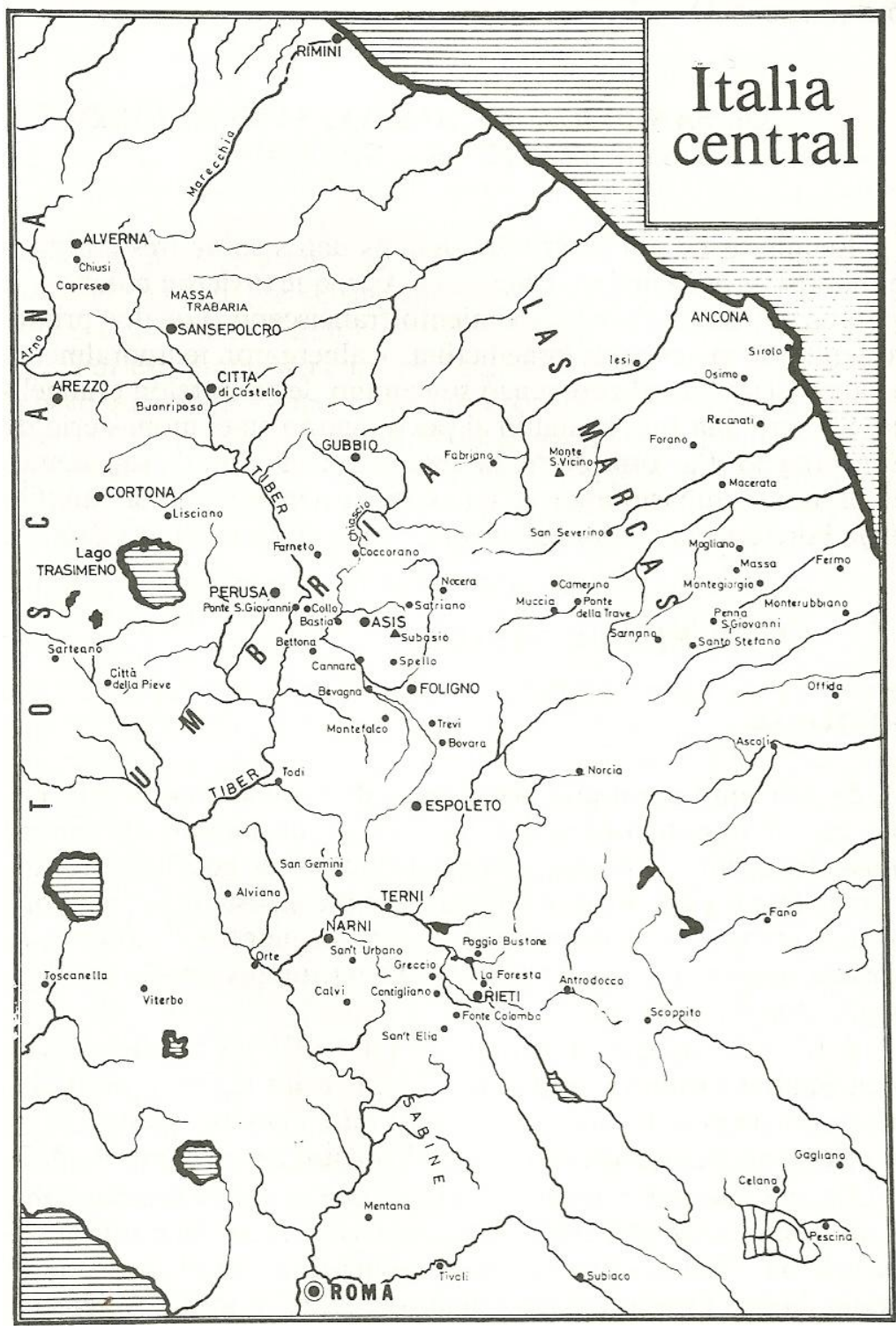

Fonte: URIBE, Fernando. Por los caminos de Francisco de Asis. Oñate: Franciscana Aránzazu, 1990, p. 114. 


\section{REGULA NON BULLATA ${ }^{399}$ [RegNB]}

[Prologus]

${ }^{1}$ In nomine Patris et Filii et Spiritus Sancti! ${ }^{2} \mathrm{Haec}$ est vita evangelii Jesu Christi, quam frater Franciscus petiit a domino papa concedi et confirmari sibi; et ille concessit et confirmavit sibi et suis fratribus habitis et futuris. ${ }^{3}$ Frater Franciscus et quicumque erit caput istius religionis promittat obedientiam domino Innocentio papae et reverentiam et suis successoribus. ${ }^{4} \mathrm{Et}$ omnes alii fratres teneantur obedire fratri Francisco et eius successoribus.

[Caput I - Quod fratres debent vivere sine proprioet in castitate et obedientia]

${ }^{1}$ Regula et vita istorum fratrum haec est, scilicet vivere in obedientia, in castitate et sine proprio, et Domini nostri Jesu Christi doctrinam et vestigia sequi, qui dicit: ${ }^{2}$ "Si vis perfectus esse, vade (Mt 19,21) et vende omnia (cfr. LC 18,22), quae habes, et da pauperibus et habebis thesaurum in caelo; et veni, sequere me» (Mt 19,21). ${ }^{3} \mathrm{Et}$ : «Si quis vult post me venire, abneget semetipsum et tollat crucem suam et sequatur me» (Mt 16, 24). ${ }^{4}$ Item: «Si quis vult venire ad me et non odit patrem et matrem et uxorem et filios et fratres et sorores, adhuc autem et animam suam, non potest meus esse discipulus» (Lc 14,26). ${ }^{5} \mathrm{Et}$ : "Omnis, qui reliquerit patrem aut matrem, fratres aut sorores, uxorem aut filios, domos aut agros propter me, centuplum accipiet et vitam aeternam possidebit» (cfr. Mt 19,29; Mc 10,29; Lc 18,29).

[Caput II - De receptione et vestimentis fratrum]

${ }^{1} \mathrm{Si}$ quis divina inspiratione volens accipere hanc vitam venerit ad nostros fratres, benigne recipiatur ab eis. ${ }^{2}$ Quodsi fuerit firmus accipere vitam nostram, multum caveant sibi fratres, ne de suis temporalibus negotiis se intromittant, sed ad suum ministrum, quam citius possunt, eum repraesentent. ${ }^{3}$ Minister vero benigne ipsum recipiat et confortet et vitae nostrae tenorem sibi

399 MENESTÒ, Enrico \& BRUFANI, Stefano. Fontes Franciscani. Assis: Edizioni Porziuncola, 1995, pp. 183-212. 
diligenter exponat. ${ }^{4}$ Quo facto, praedictus, si vult et potest spiritualiter sine impedimento, omnia sua vendat et ea omnia pauperibus studeat erogare. ${ }^{5}$ Caveant sibi fratres et minister fratrum, quod de negotiis suis nullo modo intromittant se; ${ }^{6}$ neque recipiant aliquam pecuniam neque per se neque per interpositam personam. ${ }^{7}$ Si tamen indigent, alia necessaria corporis praeter pecuniam recipere possunt fratres causa necessitatis sicut alii pauperes. ${ }^{8} \mathrm{Et}$ cum reversus fuerit, minister concedat ei pannos probationis usque ad annum, scilicet duas tunicas sine caputio et cingulum et braccas et caparonem usque ad cingulum. ${ }^{9}$ Finito vero anno et termino probationis recipiatur ad obedientiam. ${ }^{10}$ Postea non licebit ei ad aliam religionem accedere neque «extra obedientiam evagari» iuxta mandatum domini papae et secundum evangelium; quia «nemo mittens manum ad aratrum et aspiciens retro aptus est regno Dei» (Lc 9,62). ${ }^{11} \mathrm{Si}$ autem aliquis venerit, qui sua dare non potest sine impedimento et habet spiritualem voluntatem, relinquat illa, et sufficit sibi. ${ }^{12}$ Nullus recipiatur contra formam et institutionem sanctae Ecclesiae.

${ }^{13}$ Alii vero fratres, qui promiserunt obedientiam, habeant unam tunicam cum caputio et aliam sine caputio, si necesse fuerit, et cingulum et braccas. ${ }^{14} \mathrm{Et}$ omnes fratres vilibus vestibus induantur, et possint eas repeciare de saccis et aliis peciis cum benedictione Dei; quia dicit Dominus in evangelio: «Qui in veste pretiosa sunt et in deliciis» (LC 7,25) et «qui mollibus vestiuntur, in domibus regum sunt» (Mt 11,8). ${ }^{15} \mathrm{Et}$ licet dicantur hypocritae, non tamen cessent bene facere nec quaerant caras vestes in hoc saeculo, ut possint habere vestimentum in regno caelorum.

[Caput III - De divino officio et ieiunio]

${ }^{1}$ Dicit Dominus: Hoc genus daemoniorum non potest exire nisi in ieiunio et oratione (cfr. Mc 9,28); ${ }^{2}$ et iterum: «Cum ieiunatis nolite fieri sicut hypocritae tristes» (Mt 6,16). ${ }^{3}$ Propter hoc omnes fratres sive clerici sive laici faciant divinum officium, laudes et orationes, secundum quod debent facere. ${ }^{4}$ Clerici faciant officium et dicant pro vivis et pro mortuis secundum consuetudinem clericorum. ${ }^{5}$ Et pro defectu et negligentia fratrum dicant omni die Miserere mei Deus (Ps 50) cum Pater noster; ${ }^{6}$ et pro fratribus defunctis dicant De profundis (Ps 129) cum Pater noster. ${ }^{7}$ Et libros tantum necessarios ad implendum eorum 
officium possint habere. ${ }^{8} \mathrm{Et}$ laicis etiam scientibus legere psalterium liceat eis habere illud. ${ }^{9}$ Aliis vero nescientibus litteras librum habere non liceat. ${ }^{10}$ Laici dicant Credo in Deum et viginti quattuor Pater noster cum Gloria Patri pro matutino; pro laudibus vero quinque; pro prima Credo in Deum et septem Pater noster cum Gloria Patri; pro tertia, sexta et nona et unaquaque hora septem; pro vesperis duodecim; pro completorio Credo in Deum et septem Pater noster cum Gloria Patri; pro mortuis septem Pater noster cum Requiem aeternam; et pro defectu et negligentia fratrum tria Pater noster omni die.

${ }^{11} \mathrm{Et}$ similiter omnes fratres ieiunent a festo Omnium Sanctorum usque ad Natale et ab Epiphania, quando Dominus noster Jesus Christus incepit ieiunare usque ad Pascha. ${ }^{12}$ Aliis autem temporibus non teneantur secundum hanc vitam nisi sexta feria ieiunare. ${ }^{13} \mathrm{Et}$ liceat eis manducare de omnibus cibis, qui apponuntur eis, secundum evangelium (cfr. Lc 10,8).

[Caput IV - De ministris et aliis fratribus qualiter ordinentur]

${ }^{1}$ In nomine Domini! ${ }^{2}$ Omnes fratres, qui constituuntur ministri et servi aliorum fratrum, in provinciis et in locis, in quibus fuerint, collocent suos fratres, quos saepe visitent et spiritualiter moneant et confortent. ${ }^{3} \mathrm{Et}$ omnes alii fratres mei benedicti diligenter obediant eis in his, quae spectant ad salutem animae et non sunt contraria vitae nostrae. ${ }^{4} \mathrm{Et}$ faciant inter se sicut dicit Dominus: «Quaecumque vultis, ut faciant vobis homines et vos facite illis» (Mt 7,12); ${ }^{5}$ et: «Quod non vis tibi fieri, non facias alteri». ${ }^{6} \mathrm{Et}$ recordentur ministri et servi, quod dicit Dominus: Non veni ministrari, sed ministrare (Mt 20,28) et quia commissa est eis cura animarum fratrum, de quibus, si aliquid perderetur propter eorum culpam et malum exemplum, in die iudicii oportebit eos reddere rationem (cfr. Mt 12,36) coram Domino Jesu Christo.

[Caput V - De correctione fratrum in offensione]

${ }^{1}$ Ideoque animas vestras et fratrum vestrorum custodite; quia horrendum est incidere in manus Dei viventis (Hebr 10,31). ${ }^{2} \mathrm{Si}$ quis autem ministrorum alicui fratrum aliquid contra vitam nostram praeciperet vel contra animam suam, non teneatur ei obedire; quia illa obedientia non est, in qua 
delictum vel peccatum committitur. ${ }^{3}$ Verumtamen omnes fratres, qui sunt sub ministris et servis, facta ministrorum et servorum considerent rationabiliter et diligenter. ${ }^{4} \mathrm{Et}$ si viderint aliquem illorum carnaliter et non spiritualiter ambulare pro rectitudine vitae nostrae, post tertiam admonitionem, si non se emendaverit, in capitulo Pentecostes renuntient ministro et servo totius fraternitatis nulla contradictione impediente. ${ }^{5} \mathrm{Si}$ vero inter fratres ubicumque fuerit aliquis frater volens carnaliter et non spiritualiter ambulare, fratres, cum quibus est, moneant eum, instruant et corripiant humiliter et diligenter. ${ }^{6}$ Quodsi ille post tertiam admonitionem noluerit se emendare, quam citius possunt, mittant eum vel significent suo ministro et servo, qui minister et servus de eo faciat, sicut sibi secumdum Deum melius videbitur expedire.

${ }^{7}$ Et caveant omnes fratres tam ministri et servi quam alii, quod propter peccatum alterius vel malum non turbentur vel irascantur, quia diabolus propter delictum unius multos vult corrumpere; ${ }^{8}$ sed spiritualiter, sicut melius possunt, adiuvent illum qui peccavit, quia non est sanis opus medicus, sed male habentibus (cfr. Mt 9,12 cum Mc 2,17).

${ }^{9}$ Similiter omnes fratres non habeant in hoc potestatem vel dominationem maxime inter se. ${ }^{10}$ Sicut enim dicit Dominus in evangelio: «Principes gentium dominantur eorum, et qui maiores sunt potestatem exercent in eos» (Mt 20,25), non sic erit inter fratres (cfr. Mt 20,26a). ${ }^{11} \mathrm{Et}$ quicumque voluerit inter eos maior fieri, sit eorum minister (cfr. Mt 20,26b) et servus. ${ }^{12} \mathrm{Et}$ qui maior est inter eos fiat sicut minor (cfr. Lc 22,26).

${ }^{13} \mathrm{Nec}$ aliquis frater malum faciat vel malum dicat alteri; ${ }^{14} \mathrm{immo}$ magis per caritatem spiritus voluntarie serviant et obediant invicem (cfr. Gal 5,13 ).${ }^{15} \mathrm{Et}$ haec est vera et sancta obedientia Domini nostri Jesu Christi. ${ }^{16} \mathrm{Et}$ omnes fratres, quoties declinaverint a mandatis Domini et extra obedientiam evagaverint, sicut dicit propheta (Ps 118,21), sciant se esse maledictos extra obedientiam, quousque steterint in tali peccato scienter. ${ }^{17} \mathrm{Et}$ quando perseveraverint in mandatis Domini, quae promiserunt per sanctum evangelium et vitam ipsorum, sciant se in vera obedientia stare, et benedicti sint a Domino.

[Caput VI - De recursu fratrum ad ministros et quod aliquis frater non vocetur prior] 
${ }^{1}$ Fratres, in quibuscumque locis sunt, si non possunt vitam nostram observare, quam citius possunt, recurrant ad suum ministrum hoc sibi significantes. ${ }^{2}$ Minister vero taliter eis studeat providere, sicut ipse vellet sibi fieri, si in consimili casu esset (cfr. Mt 7,12). ${ }^{3} \mathrm{Et}$ nullus vocetur prior, sed generaliter omnes vocentur fratres minores. ${ }^{4} \mathrm{Et}$ alter alterius lavet pedes (cfr. Joa 13,14).

[Caput VII - De modo serviendi et laborandi]

${ }^{1}$ Omnes fratres, in quibuscumque locis steterint apud alios ad serviendum vel laborandum, non sint camerarii neque cancellarii neque praesint in domibus, in quibus serviunt; nec recipiant aliquod officium, quod scandalum generet vel animae suae faciat detrimentum (cfr. Mc 8,36); ${ }^{2}$ sed sint minores et subditi omnibus, qui in eadem domo sunt.

${ }^{3}$ Et fratres, qui sciunt laborare, laborent et eandem artem exerceant, quam noverint, si non fuerit contra salutem animae et honeste poterit operari. ${ }^{4}$ Nam propheta ait: «Labores fructuum tuorum manducabis; beatus es et bene tibi erit» (Ps 127,2;-R); ${ }^{5}$ et apostolus: Qui non vult operari non manducet (cfr. 2 Thess 3,10); ${ }^{6}$ et: Unusquisque in ea arte et officio, in quo vocatus est, permaneat (cfr. 1 Cor 7,24 ). ${ }^{7}$ Et pro labore possint recipere omnia necessaria praeter pecuniam. ${ }^{8} \mathrm{Et}$ cum necesse fuerit, vadant pro eleemosynis sicut alii pauperes. ${ }^{9} \mathrm{Et}$ liceat eis habere ferramenta et instrumenta suis artibus opportuna.

${ }^{10}$ Omnes fratres studeant bonis operibus insudare, quia scriptum est: Semper facito aliquid boni, ut te diabolus inveniat occupatum. ${ }^{11} \mathrm{Et}$ iterum: Otiositas inimica est animae. ${ }^{12}$ Ideo servi Dei semper orationi vel alicui bonae operationi insistere debent.

${ }^{13}$ Caveant sibi fratres, ubicumque fuerint in eremis vel in aliis locis, quod nullum locum sibi approprient nec alicui defendant. ${ }^{14} \mathrm{Et}$ quicumque ad eos venerit amicus vel adversarius, fur vel latro benigne recipiatur. ${ }^{15} \mathrm{Et}$ ubicumque sunt fratres et in quocumque loco se invenerint, spiritualiter et diligenter debeant se revidere et honorare ad invicem sine murmuratione (1 Petr 4,9). ${ }^{16} \mathrm{Et}$ caveant sibi, quod non se ostendant tristes extrinsecus et nubilosos hypocritas; 
sed ostendant se gaudentes in Domino (cfr. Phil 4,4) et hilares et convenienter gratiosos.

[Caput VIII - Quod fratres non recipiant pecuniam]

1Dominus praecipit in evangelio: Videte, cavete ab omni malitia et avaritia (cfr. Lc 12,15); ${ }^{2}$ et: Attendite vobis a sollicitudine huius saeculi et a curis huius vitae (cfr. Lc 21,34).

${ }^{3}$ Unde nullus fratrum, ubicumque sit et quocumque vadit, aliquo modo tollat nec recipiat nec recipi faciat pecuniam aut denarios neque occasione vestimentorum nec librorum nec pro pretio alicuius laboris, immo nulla occasione, nisi propter manifestam necessitatem infirmorum fratrum; quia non debemus maiorem utilitatem habere et reputare in pecunia et denariis quam in lapidibus. ${ }^{4} \mathrm{Et}$ illos vult diabolus excaecare, qui eam appetunt vel reputant lapidibus meliorem. ${ }^{5}$ Caveamus ergo nos, qui omnia relinquimus (cfr. Mt 19,27), ne pro tam modico regnum caelorum perdamus. ${ }^{6} \mathrm{Et} \mathrm{si}$ in aliquo loco inveniremus denarios, de his non curemus tamquam de pulvere, quem pedibus calcamus, quia vanitas vanitatum et omnia vanitas (Eccle 1,2). ${ }^{7}$ Et si forte, quod absit, aliquem fratrem contigerit pecuniam vel denarios colligere vel habere, excepta solummodo praedicta infirmorum necessitate, omnes fratres teneamus eum pro falso fratre et apostata et fure et latrone et loculos habente (cfr. Joa $12,6)$, nisi vere poenituerit. ${ }^{8} \mathrm{Et}$ nullo modo fratres recipiant nec recipi faciant nec quaerant nec quaeri faciant pecuniam pro eleemosyna neque denarios pro aliquibus domibus vel locis; neque cum persona pro talibus locis pecunias vel denarios quaerente vadant. ${ }^{9} \mathrm{Alia}$ autem servitia, quae non sunt contraria vitae nostrae, possunt fratres locis facere cum benedictione Dei. ${ }^{10}$ Fratres tamen in manifesta necessitate leprosorum possunt pro eis quaerere eleemosynam. ${ }^{11}$ Caveant tamen multum a pecunia. ${ }^{12}$ Similiter caveant omnes fratres, ut pro nullo turpi lucro terras circueant.

[Caput IX - De petenda eleemosyna]

${ }^{1}$ Omnes fratres studeant sequi humilitatem et paupertatem Domini nostri Jesu Christi et recordentur, quod nihil aliud oportet nos habere de toto 
mundo, nisi, sicut dicit apostolus, habentes alimenta et quibus tegamur, his contenti sumus (cfr. 1 Tim 6,8). ${ }^{2} \mathrm{Et}$ debent gaudere, quando conversantur inter viles et despectas personas, inter pauperes et debiles et infirmos et leprosos et iuxta viam mendicantes. ${ }^{3} \mathrm{Et}$ cum necesse fuerit, vadant pro eleemosynis. ${ }^{4} \mathrm{Et}$ non verecundentur et magis recordentur, quia Dominus noster Jesus Christus, Filius Dei vivi (Joa 11,27) omnipotentis, posuit faciem suam ut petram durissimam (Is 50,7), nec verecundatus fuit. ${ }^{5} \mathrm{Et}$ fuit pauper et hospes et vixit de eleemosynis ipse et beata Virgo et discipuli eius. ${ }^{6} \mathrm{Et}$ quando facerent eis homines verecundiam et nollent eis dare eleemosynam, referant inde gratias Deo; quia de verecundiis recipient magnum honorem ante tribunal Domini nostri Jesu Christi. ${ }^{7}$ Et sciant, quod verecundia non patientibus, sed inferentibus imputatur. ${ }^{8} \mathrm{Et}$ eleemosyna est hereditas et iustitia, quae debetur pauperibus, quam nobis acquisivit Dominus noster Jesus Christus. ${ }^{9} \mathrm{Et}$ fratres, qui eam acquirendo laborant, magnam mercedem habebunt et faciunt lucrari et acquirere tribuentes; quia omnia, quae relinquent homines in mundo peribunt, sed de caritate et de eleemosynis, quas fecerunt, habebunt praemium a Domino.

${ }^{10} \mathrm{Et}$ secure manifestet unus alteri necessitatem suam, ut sibi necessaria inveniat et ministret. ${ }^{11} \mathrm{Et}$ quilibet diligat et nutriat fratrem suum, sicut mater diligit et nutrit filium suum (cfr. 1 Thess 2,7), in quibus ei Deus gratiam largietur. ${ }^{12}$ Et qui non manducat, manducantem non iudicet (Rom 14,3b).

${ }^{13} \mathrm{Et}$ quandocumque necessitas supervenerit, liceat universis fratribus, ubicumque fuerint, uti omnibus cibis, quos possunt homines manducare, sicut Dominus dicit de David, qui comedit panes propositionis (cfr. Mt 12,4), quos non licebat manducare nisi sacerdotibus (Mc 2,26). ${ }^{14} \mathrm{Et}$ recordentur, quod dicit Dominus: Attendite autem vobis, ne forte graventur corda vestra in crapula et ebrietate et curis huius vitae et superveniat in vobis repentina dies illa; ${ }^{15}$ tanquam enim laqueus superveniet in omnes, qui sedent super faciem orbis terrae (cfr. Lc 21,34-35). ${ }^{16}$ Similiter etiam tempore manifestae necessitatis faciant omnes fratres de eorum necessariis, sicut eis Dominus gratiam largietur, quia necessitas non habet legem.

[Caput X - De infirmis fratribus] 
${ }^{1} \mathrm{Si}$ quis fratrum in infirmitate ceciderit, ubicumque fuerit, alii fratres non dimittant eum, nisi constituatur unus de fratribus vel plures, si necesse fuerit, qui serviant ei, sicut vellent sibi serviri (cfr. Mt 7,12); ${ }^{2}$ sed in maxima necessitate possunt ipsum dimittere alicui personae, quae suae debeat satisfacere infirmitati. ${ }^{3} \mathrm{Et}$ rogo fratrem infirmum, ut referat de omnibus gratias Creatori; et quod qualem vult eum Dominus, talem se esse desideret sive sanum sive infirmum, quia omnes, quos Deus ad vitam praeordinavit aeternam (cfr. Act 13,48), flagellorum atque infirmitatum stimulis et compunctionis spiritu erudit, sicut Dominus dicit: «Ego quos amo corrigo et castigo» (Apoc 3,19). ${ }^{4} \mathrm{Et}$ si quis turbabitur vel irascetur sive contra Deum sive contra fratres, vel si forte sollicite postulaverit medicinas nimis desiderans liberare carnem cito morituram, quae est animae inimica, a malo sibi evenit et carnalis est, et non videtur esse de fratribus, quia plus diligit corpus quam animam.

[Caput XI - Quod fratres non blasphement nec detrahant, sed diligant se ad invicem]

${ }^{1} \mathrm{Et}$ omnes fratres caveant sibi, ut non calumnientur neque contendant verbis (cfr. 2 Tim 2,14); ${ }^{2}$ immo studeant retinere silentium, quandocumque eis Deus gratiam largietur. ${ }^{3}$ Neque litigent inter se neque cum aliis, sed procurent humiliter respondere dicentes: Inutilis servus sum (cfr. Lc 17,10). ${ }^{4} \mathrm{Et}$ non irascantur, quia omnis, qui irascitur fratri suo, reus erit iudicio; qui dixerit fratri suo: raca, reus erit concilio; qui dixerit: fatue, reus erit gehennae ignis (Mt 5,22). ${ }^{5}$ Et diligant se ad invicem, sicut dicit Dominus: «Hoc est praeceptum meum ut diligatis invicem, sicut dilexi vos» (Joa 15,12). ${ }^{6} \mathrm{Et}$ ostendant ex operibus (cfr. Jac 2,18) dilectionem, quam habent ad invicem, sicut dicit apostolus: "Non diligamus verbo neque lingua, sed opere et veritate» (1 Joa 3,18). ${ }^{7}$ Et neminem blasphement (cfr. Tit 3,2). ${ }^{8}$ Non murmurent, non detrahant aliis, quia scriptum est: Susurrones et detractores Deo sunt odibiles (cfr. Rom 1,29). ${ }^{9} \mathrm{Et}$ sint modesti omnem ostendentes mansuetudinem ad omnes homines (cfr. Tit 3,2). ${ }^{10}$ Non iudicent, non condemnent. ${ }^{11} \mathrm{Et}$ sicut dicit Dominus, non considerent minima peccata aliorum (cfr. Mt 7,3; Lc 6,41); ${ }^{12}$ immo magis sua recogitent in amaritudine animae suae (Is 38,15$).{ }^{13} \mathrm{Et}$ contendant intrare per angustam 
portam (Lc 13,24), quia dicit Dominus: «Angusta porta et arcta via est, quae ducit ad vitam; et pauci sunt, qui inveniunt eam» (Mt 7,14).

[Caput XII - De malo visu et frequentia mulierum]

${ }^{1}$ Omnes fratres, ubicumque sunt vel vadunt, caveant sibi a malo visu et frequentia mulierum. ${ }^{2} \mathrm{Et}$ nullus cum eis consilietur aut per viam vadat solus aut ad mensam in una paropside comedat. ${ }^{3}$ Sacerdotes honeste loquantur cum eis dando poenitentiam vel aliud spirituale consilium. ${ }^{4}$ Et nulla penitus mulier ab aliquo fratre recipiatur ad obedientiam, sed dato sibi consilio spirituali, ubi voluerit, agat poenitentiam. ${ }^{5} \mathrm{Et}$ multum omnes nos custodiamus et omnia membra nostra munda teneamus, quia dicit Dominus: «Qui viderit mulierem ad concupiscendam eam, iam moechatus est eam in corde suo" (Mt 5,28); ${ }^{6}$ et apostolus: An ignoratis, quia membra vestra templum sunt Spiritus Sancti? (cfr. 1 Cor 6,19); itaque qui templum Dei violaverit, disperdet illum Deus (1 Cor $3,17)$.

[Caput XIII - De vitanda fornicatione]

${ }^{1}$ Si quis fratrum diabolo instigante fornicaretur, habitu exuatur quem pro sua turpi iniquitate amisit, et ex toto deponat et a nostra religione penitus repellatur. ${ }^{2}$ Et postea poenitentiam faciat de peccatis (cfr. 1 Cor 5,4-5).

[Caput XIV - Quomodo fratres debeant ire per mundum]

${ }^{1}$ Quando fratres vadunt per mundum, nihil portent per viam neque (cfr. Lc 9,3) sacculum (cfr. Lc 10,4) neque peram neque panem neque pecuniam (cfr. Lc 9,3) neque virgam (cfr. Mt 10,10). ${ }^{2} \mathrm{Et}$ in quamcumque domum intraverint, dicant primum: Pax huic domui (cfr. Lc 10,5). ${ }^{3} \mathrm{Et}$ in eadem domo manentes edant et bibant quae apud illos sunt (cfr. Lc 10,7). ${ }^{4}$ Non resistant malo (cfr. Mt 5,39), sed qui eos percusserit in una maxilla, praebeant et alteram (cfr. Mt 5,39 et Lc 6,29). ${ }^{5} \mathrm{Et}$ qui aufert eis vestimentum, et tunicam non prohibeant (cfr. Lc 6,29). ${ }^{6}$ Omni petenti se tribuant; et qui aufert quae sua sunt, ea non repetant (cfr. Lc 6,30). 
[Caput XV - Quod fratres non equitent]

${ }^{1}$ Iniungo omnibus fratribus meis tam clericis quam laicis euntibus per mundum vel morantibus in locis, quod nullo modo apud se nec apud alium nec alio aliquo modo bestiam aliquam habeant. ${ }^{2} \mathrm{Nec}$ eis liceat equitare, nisi infirmitate vel magna necessitate cogantur.

[Caput XVI - De euntibus inter saracenos et alios infideles]

1Dicit Dominus: «Ecce ego mitto vos sicut oves in medio luporum». ${ }^{2}$ Estote ergo prudentes sicut serpentes et simplices sicut columbae (Mt 10,16). ${ }^{3}$ Unde quicumque frater voluerit ire inter saracenos et alios infideles, vadat de licentia sui ministri et servi. ${ }^{4} \mathrm{Et}$ minister det eis licentiam et non contradicat, si viderit eos idoneos ad mittendum; nam tenebitur Domino reddere rationem (cfr. Lc 16,2), si in hoc vel in aliis processerit indiscrete. ${ }^{5}$ Fratres vero, qui vadunt, duobus modis inter eos possunt spiritualiter conversari. ${ }^{6}$ Unus modus est, quod non faciant lites neque contentiones, sed sint subditi omni humanae creaturae propter Deum (1 Petr 2,13 ) et confiteantur se esse christianos. ${ }^{7}$ Alius modus est, quod, cum viderint placere Domino, annuntient verbum Dei, ut credant Deum omnipotentem Patrem et Filium et Spiritum Sanctum, creatorem omnium, redemptorem et salvatorem Filium, et ut baptizentur et efficiantur christiani, quia quis renatus non fuerit ex aqua et Spiritu Sancto, non potest intrare in regnum Dei (cfr. Joa 3,5).

${ }^{8} \mathrm{Haec}$ et alia, quae placuerint Domino, ipsis et aliis dicere possunt, quia dicit Dominus in evangelio: Omnis, qui confitebitur me coram hominibus, confitebor et ego eum coram Patre meo, qui in caelis est (Mt 10,32). ${ }^{9} \mathrm{Et}$ : Qui erubuerit me et sermones meos, et Filius hominis erubescet eum, cum venerit in maiestate sua et Patris et angelorum (cfr. Lc 9,26).

${ }^{10} \mathrm{Et}$ omnes fratres, ubicumque sunt, recordentur, quod dederunt se et reliquerunt corpora sua Domino Jesu Christo. ${ }^{11}$ Et pro eius amore debent se exponere inimicis tam visibilibus quam invisibilibus; quia dicit Dominus: Qui perdiderit animam suam propter me, salvam faciet eam (cfr. Lc 9,24) in vitam aeternam (Mt 25,46). ${ }^{12}$ Beati qui persecutionem patiuntur propter iustitiam, 
quoniam ipsorum est regnum caelorum (Mt 5,10). ${ }^{13}$ Si me persecuti sunt, et vos persequentur (Joa 15,20). ${ }^{14} \mathrm{Et}$ : Si persequuntur vos in una civitate, fugite in aliam (cfr. Mt 10,23). ${ }^{15}$ Beati estis (Mt 5, 11), cum vos oderint homines (Lc 6,22) et maledixerint vobis (Mt 5,11) et persequentur vos (cfr. I. c.) et separaverint vos et exprobraverint et eiecerint nomen vestrum tamquam malum (LC 6,22) et cum dixerint omne malum adversum vos mentientes propter me (Mt 5,11). ${ }^{16}$ Gaudete in illa die et exsultate (Lc 6,23), quoniam merces vestra, multa est in caelis (cfr. Mt 5,12). ${ }^{17} \mathrm{Et}$ ego dico vobis amicis meis, non terreamini ab his (cfr. Lc 12,4$),{ }^{18}$ et nolite timere eos qui occidunt corpus (Mt 10,28) et post hoc non habent amplius quid faciant (LC 12,4). ${ }^{19}$ Videte, ne turbemini (Mt 24,6). ${ }^{20} / n$ patientia enim vestra possidebitis animas vestras (LC 21,19); ${ }^{21}$ et qui perseveraverit usque in finem, hic salvus erit (Mt 10,22; 24,13).

\section{[Caput XVII - De praedicatoribus]}

${ }^{1}$ Nullus frater praedicet contra formam et institutionem sanctae Ecclesiae et nisi concessum sibi fuerit a ministro suo. ${ }^{2} \mathrm{Et}$ caveat sibi minister, ne alicui indiscrete concedat. ${ }^{3}$ Omnes tamen fratres operibus praedicent. ${ }^{4} \mathrm{Et}$ nullus minister vel praedicator appropriet sibi ministerium fratrum vel officium praedicationis, sed quacumque hora ei iniunctum fuerit, sine omni contradictione dimittat suum officium.

${ }^{5}$ Unde deprecor in caritate, quae Deus est (cfr. 1 Joa 4,16), omnes fratres meos praedicatores, oratores, laboratores, tam clericos quam laicos, ut studeant se humiliare in omnibus, ${ }^{6}$ non gloriari nec in se gaudere nec interius se exaltare de bonis verbis et operibus, immo de nullo bono, quod Deus facit vel dicit et operatur in eis aliquando et per ipsos, secundum quod dicit Dominus: "Veruntamen in hoc nolite gaudere, quia spiritus vobis subiciuntur» (Lc 10,20). ${ }^{7}$ Et firmiter sciamus, quia non pertinent ad nos nisi vitia et peccata. ${ }^{8} \mathrm{Et}$ magis debemus gaudere, cum in tentationes varias incideremus (cfr. Jac 1,2) et cum sustineremus quascumque animae vel corporis angustias aut tribulationes in hoc mundo propter vitam aeternam.

${ }^{9}$ Omnes ergo fratres caveamus ab omni superbia et vana gloria. ${ }^{10} \mathrm{Et}$ custodiamus nos a sapientia huius mundi et a prudentia carnis (Rom 8,6). ${ }^{11}$ Spiritus enim carnis vult et studet multum ad verba habenda, sed parum ad 
operationem; ${ }^{12}$ et quaerit non religionem et sanctitatem in interiori spiritu, sed vult et desiderat habere religionem et sanctitatem foris apparentem hominibus. ${ }^{13} \mathrm{Et}$ isti sunt, de quibus dicit Dominus: Amen dico vobis, receperunt mercedem suam (Mt 6,2). ${ }^{14}$ Spiritus autem Domini vult mortificatam et despectam, vilem et abiectam esse carnem. ${ }^{15} \mathrm{Et}$ studet ad humilitatem et patientiam et puram et simplicem et veram pacem spiritus. ${ }^{16} \mathrm{Et}$ semper super omnia desiderat divinum timorem et divinam sapientiam et divinum amorem Patris et Filii et Spiritus Sancti.

${ }^{17}$ Et omnia bona Domino Deo altissimo et summo reddamus et omnia bona ipsius esse cognoscamus et de omnibus ei gratias referamus, a quo bona cuncta procedunt. ${ }^{18} \mathrm{Et}$ ipse altissimus et summus, solus verus Deus habeat et ei reddantur et ipse recipiat omnes honores et reverentias, omnes laudes et benedictiones, omnes gratias et gloriam, cuius est omne bonum, qui solus est bonus (cfr. Lc 18,19).

${ }^{19} \mathrm{Et}$ quando nos videmus vel audimus malum dicere vel facere vel blasphemare Deum, nos bene dicamus et bene faciamus et laudemus Deum (cfr. Rom 12,21), qui est benedictus in saecula (Rom 1,25).

[Caput XVIII - Qualiter ministri conveniant ad invicem]

${ }^{1}$ Quolibet anno unusquisque minister cum fratribus suis possit convenire, ubicumque placuerit eis, in festo sancti Michaelis archangeli de his quae ad Deum pertinent, tractaturus. ${ }^{2}$ Omnes enim ministri, qui sunt in ultramarinis et ultramontanis partibus, semel in tribus annis, et alii ministri semel in anno veniant ad capitulum Pentecostes apud ecclesiam sanctae Mariae de Portiuncula, nisi a ministro et servo totius fraternitatis aliter fuerit ordinatum.

[Caput XIX - Quod fratres vivant catholice]

${ }^{1}$ Omnes fratres sint catholici, vivant et loquantur catholice. ${ }^{2} \mathrm{Si}$ quis vero erraverit a fide et vita catholica in dicto vel in facto et non se emendaverit, a nostra fraternitate penitus expellatur. ${ }^{3} \mathrm{Et}$ omnes clericos et omnes religiosos habeamus pro dominis in his quae spectant ad salutem animae et a nostra 
religione non deviaverint, et ordinem et officium eorum et administrationem in Domino veneremur.

[Caput XX - De poenitentia et receptione corporis et sanguinis Domini nostri Jesu Christi]

${ }^{1}$ Et fratres mei benedicti tam clerici quam laici confiteantur peccata sua sacerdotibus nostrae religionis. ${ }^{2}$ Et si non potuerint, confiteantur aliis discretis et catholicis sacerdotibus scientes firmiter et attendentes, quia a quibuscumque sacerdotibus catholicis acceperint poenitentiam et absolutionem, absoluti erunt procul dubio ab illis peccatis, si poenitentiam sibi iniunctam procuraverint humiliter et fideliter observare. ${ }^{3} \mathrm{Si}$ vero tunc non potuerint habere sacerdotem, confiteantur fratri suo, sicut dicit apostolus Jacobus: «Confitemini alterutrum peccata vestra» (Jac 5,16). ${ }^{4}$ Non tamen propter hoc dimittant recurrere ad sacerdotem, quia potestas ligandi et solvendi solis sacerdotibus est concessa. ${ }^{5}$ Et sic contriti et confessi sumant corpus et sanguinem Domini nostri Jesu Christi cum magna humilitate et veneratione recordantes, quod Dominus dicit: Qui manducat carnem meam et bibit sanguinem meum habet vitam aeternam (cfr. Joa 6,55); ${ }^{6}$ et: «Hoc facite in meam commemorationem» (Lc 22,19).

[Caput XXI - De laude et exhortatione, quam possunt omnes fratres facere]

${ }^{1}$ Et hanc vel talem exhortationem et laudem omnes fratres mei, quandocumque placuerit eis, annuntiare possunt inter quoscumque homines cum benedictione Dei: ${ }^{2}$ Timete et honorate, laudate et benedicite, gratias agite (1 Thess 5,18) et adorate Dominum Deum omnipotentem in trinitate et unitate, Patrem et Filium et Spiritum Sanctum, creatorem omnium. ${ }^{3}$ Agite poenitentiam (cfr. Mt 3,2), facite dignos fructus poenitentiae (cfr. Lc 3,8), quia cito moriemur. ${ }^{4}$ Date et dabitur vobis (Lc 6,38). ${ }^{5}$ Dimittite et dimittetur vobis (cfr. Lc 6,37). ${ }^{6} \mathrm{Et}$ si non dimiseritis hominibus peccata eorum (Mt 6,14), Dominus non dimittet vobis peccata vestra (Mc 11,25); confitemini omnia peccata vestra (cfr. Jac 5,16). ${ }^{7}$ Beati qui moriuntur in poenitentia, quia erunt in regno caelorum. ${ }^{8} \mathrm{Vae}$ illis qui non moriuntur in poenitentia, quia erunt filii diaboli (1 Joa 3,10 ), cuius opera 
faciunt (cfr. Joa 8,41) et ibunt in ignem aeternum (Mt 18,8; 25,41). ${ }^{9}$ Cavete et abstinete ab omni malo et perseverate usque in finem in bono.

[Caput XXII - De admonitione fratrum]

${ }^{1}$ Attendamus, omnes fratres, quod dicit Dominus: Diligite inimicos vestros et benefacite his qui oderunt vos (cfr. Mt 5,44 par.), '²uia Dominus noster Jesus Christus, cuius sequi vestigia debemus (cfr. 1 Petr 2,21), traditorem suum vocavit amicum (cfr. Mt 26,50) et crucifixoribus suis sponte se obtulit. ${ }^{3}$ Amici igitur nostri sunt omnes illi, qui nobis iniuste inferunt tribulationes et angustias, verecundias et iniurias, dolores et tormenta, martyrium et mortem; ${ }^{4}$ quos multum diligere debemus, quia ex hoc quod nobis inferunt, habemus vitam aeternam.

${ }^{5} \mathrm{Et}$ odio habeamus corpus nostrum cum vitiis et peccatis suis; quia carnaliter vivendo vult diabolus a nobis auferre amorem Jesu Christi et vitam aeternam et se ipsun cum omnibus perdere in infernum; ${ }^{6}$ quia nos per culpam nostram sumus foetidi, miseri et bono contrarii, ad mala autem prompti et voluntarii, quia sicut Dominus dicit in evangelio: ${ }^{7} \mathrm{De}$ corde procedunt et exeunt cogitationes malae, adulteria, fornicationes, homicidia, furta, avaritia, nequitia, dolus, impudicitia, oculus malus, falsa testimonia, blasphemia, stultitia (cfr. Mc 7,21-22; Mt 15,19). ${ }^{8}$ Haec omnia mala ab intus de corde hominis procedunt (cfr. Mc 7,23 ) et haec sunt quae coinquinant hominem (Mt 15,20).

${ }^{9}$ Nunc autem, postquam dimisimus mundum, nihil aliud habemus facere, nisi sequi voluntatem Domini et placere sibi ipsi. ${ }^{10}$ Multum caveamus, ne simus terra secus viam vel petrosa vel spinosa, secundum quod dicit Dominus in evangelio: ${ }^{11}$ Semen est verbum Dei (LC 8,11). ${ }^{12}$ Quod autem secus viam cecidit et conculcatum est (cfr. Lc 8,5), hi sunt, qui audiunt (Lc 8,12) verbum et non intelligunt (cfr. Mt 13,19); ${ }^{13}$ et confestim (Mc 4,15) venit diabolus (Lc 8,12) et rapit (Mt 13,19), quod seminatum est in cordibus eorum (Mc 4,15$)$ et tollit verbum de cordibus eorum, ne credentes salvi fiant (LC 8,12). ${ }^{14}$ Quod autem super petrosam cecidit (cfr. Mt 13,20), hi sunt, qui, cum audierint verbum, statim cum gaudio (Mc 4,16) suscipiunt (Lc 8,13) illud (Mc 4,16). ${ }^{15}$ Facta autem tribulatione et persecutione propter verbum, continuo scandalizantur (Mt 13,21) et hi radicem in se non habent, sed temporales sunt (cfr. Mc 4,17), quia ad 
tempus credunt et in tempore tentationis recedunt (Lc 8,13). ${ }^{16}$ Quod autem in spinis cecidit, hi sunt (Lc 8,14), qui verbum Dei audiunt (cfr. Mc 4,18), et sollicitudo (Mt 13,22) et aerumnae (Mc 4,19) istius saeculi et fallacia divitiarum (Mt 13,22) et circa reliqua concupiscentiae introeuntes suffocant verbum et sine fructu efficiuntur (cfr. Mc 4,19). ${ }^{17}$ Quod autem in terram bonam (Lc 8,15) seminatum est (Mt 13,23), hi sunt, qui in corde bono et optimo audientes verbum (LC 8,15) intelligunt et (cfr. Mt 13,23) retinent et fructum afferunt in patientia (Lc 8,15$).{ }^{18} \mathrm{Et}$ propterea nos fratres, sicut dicit Dominus, dimittamus mortuos sepelire mortuos suos (Mt 8,22).

${ }^{19} \mathrm{Et}$ multum caveamus a malitia et subtilitate satanae, qui vult, quod homo mentem suam et cor non habeat ad Deum. ${ }^{20} \mathrm{Et}$ circuiens desiderat cor hominis sub specie alicuius mercedis vel adiutorii tollere et suffocare verbum et praecepta Domini a memoria et volens cor hominis per saecularia negotia et curam excaecare et ibi habitare, sicut dicit Dominus: ${ }^{21}$ Cum immundus spiritus exierit ab homine, ambulat per loca arida (Mt 12,43) et inaquosa quaerens requiem; ${ }^{22}$ et non inveniens dicit: Revertar in domum meam, unde exivi (LC $11,24) .{ }^{23} E t$ veniens invenit eam vacantem, scopis mundatam et ornatam (Mt 12,44). ${ }^{24} \mathrm{Et}$ vadit et assumit alios septem spiritus nequiores se, et ingressi habitant ibi, et sunt novissima hominis illius peiora prioribus (cfr. Lc 11,26).

${ }^{25}$ Unde, omnes fratres. custodiamus nos multum, ne sub specie alicuius mercedis vel operis vel adiutorii perdamus vel tollamus nostram mentem et cor a Domino. ${ }^{26}$ Sed in sancta caritate, quae Deus est (cfr. 1 Joa 4,16), rogo omnes fratres tam ministros quam alios, ut omni impedimento remoto et omni cura et sollicitudine postposita, quocumque modo melius possunt, servire, amare, honorare et adorare Dominum Deum mundo corde et pura mente faciant, quod ipse super omnia quaerit. ${ }^{27} \mathrm{Et}$ semper faciamus ibi habitaculum et mansionem (cfr. Joa 14,23) ipsi, qui est Dominus Deus omnipotens, Pater et Filius et Spiritus Sanctus, qui dicit: Vigilate itaque omni tempore orantes, ut digni habeamini fugere omnia mala, quae ventura sunt et stare ante Filium hominis (LC 21,36). ${ }^{28}$ Et cum stabitis ad orandum (Mc 11,25) dicite (LC 11,2): Pater noster qui es in caelis (Mt 6,9). ${ }^{29} \mathrm{Et}$ adoremus eum puro corde, quoniam oportet semper orare et non deficere (LC 18,1); ${ }^{30}$ nam Pater tales quaerit adoratores. ${ }^{31}$ Spiritus est Deus, et eos qui adorant eum, in spiritu et veritate oportet eum adorare (cfr. Joa 4,23-24). ${ }^{32} \mathrm{Et}$ ad ipsum recurramus tamquam ad pastorem et 
episcopum animarum nostrarum (1 Petr 2,25), qui dicit: Ego sum pastor bonus, qui pasco oves meas et pro ovibus meis pono animam meam. ${ }^{33}$ Omnes vos fratres estis; ${ }^{34}$ et patrem nolite vobis vocare super terram, unus est enim Pater vester, qui in caelis est. ${ }^{35} \mathrm{Nec}$ vocemini magistri; unus est enim magister vester, qui in caelis est (cfr. Mt 23,8-10). ${ }^{36}$ Si manseritis in me, et verba mea in vobis manserint, quodcumque volueritis, petetis et fiet vobis (Joa 15,7). ${ }^{37}$ Ubicumque sunt duo vel tres congregati in nomine meo, ibi sum in medio eorum (Mt 18,20). ${ }^{38}$ Ecce ego sum vobiscum usque ad consummationem saeculi (Mt 28,20). ${ }^{39}$ Verba, quae locutus sum vobis, spiritus et vita sunt (Joa 6,64). ${ }^{40}$ Ego sum via, veritas et vita (Joa 14,6).

${ }^{41}$ Teneamus ergo verba, vitam et doctrinam et sanctum eius evangelium, qui dignatus est pro nobis rogare Patrem suum et nobis eius nomen manifestare dicens: Pater clarifica nomen tuum (Joa 12,28a) et clarifica Filium tuum, ut Filius tuus clarificet te (Joa 17,1b). ${ }^{42}$ Pater, manifestavi nomen tuum hominibus, quos dedisti mihi (Joa 17,6); quia verba, quae dedisti mihi, dedi eis; et ipsi acceperunt et cognoverunt, quia a te exivi et crediderunt, quia tu me misisti. ${ }^{43}$ Ego pro eis rogo, non pro mundo, ${ }^{44}$ sed pro his quos dedisti mihi, quia tui sunt et omnia mea tua sunt (Joa 17,8-10). ${ }^{45}$ Pater sancte, serva eos in nomine tuo, quos dedisti mihi, ut ipsi sint unum sicut et nos (Joa 17,11b). ${ }^{46} \mathrm{Haec}$ loquor in mundo, ut habeant gaudium in semetipsis. ${ }^{47}$ Ego dedi eis sermonem tuum; et mundus eos odio habuit, quia non sunt de mundo, sicut et ego non sum de mundo. ${ }^{48}$ Non rogo, ut tollas eos de mundo, sed ut serves eos a malo (Joa 17,13b-15). ${ }^{49}$ Mirifica eos in veritate. ${ }^{50}$ Sermo tuus veritas est. ${ }^{51}$ Sicut tu me misisti in mundum, et ego misi eos in mundum. ${ }^{52} \mathrm{Et}$ pro eis sanctifico meipsum, ut sint ipsi sanctificati in veritate. ${ }^{53}$ Non pro eis rogo tantum, sed pro eis, qui credituri sunt propter verbum eorum in me (cfr. Joa 17,17-20), ut sint consummati in unum, et cognoscat mundus, quia tu me misisti et dilexisti eos, sicut me dilexisti (Joa 17,23). ${ }^{54} E t$ notum faciam eis nomen tuum, ut dilectio, qua dilexisti me sit in ipsis et ego in ipsis (cfr. Joa 17,26). ${ }^{55}$ Pater, quos dedisti mihi, volo, ut ubi ego sum, et illi sint mecum, ut videant claritatem tuam (cfr. Joa 17,24) in regno tuo (Mt 20,21). Amen.

[Caput XXIII - Oratio et gratiarum actio] 
${ }^{1}$ Omnipotens, sanctissime, altissime et summe Deus, Pater sancte (Joa $17,11)$ et iuste, Domine rex caeli et terrae (cfr. Mt 11,25), propter temetipsum gratias agimus tibi, quod per sanctam voluntatem tuam et per unicum Filium tuum cum Spiritu Sancto creasti omnia spiritualia et corporalia et nos ad imaginem tuam et similitudinem factos in paradiso posuisti (cfr. Gen 1,26; 2,15). ${ }^{2} \mathrm{Et}$ nos per culpam nostram cecidimus. ${ }^{3} \mathrm{Et}$ gratias agimus tibi, quia, sicut per Filium tuum nos creasti, sic per sanctam dilectionem tuam, qua dilexisti nos (cfr. Joa 17,26), ipsum verum Deum et verum hominem ex gloriosa semper Virgine beatissima sancta Maria nasci fecisti et per crucem et sanguinem et mortem ipsius nos captivos redimi voluisti. ${ }^{4}$ Et gratias agimus tibi, quia ipse Filius tuus venturus est in gloria maiestatis suae mittere maledictos, qui poenitentiam non egerunt et te non cognoverunt, in ignem aeternum, et dicere omnibus, qui te cognoverunt et adoraverunt et tibi servierunt in poenitentia: Venite, benedicti Patris mei, pericipite regnum, quod vobis paratum est ab origine mundi (cfr. Mt 25,34).

${ }^{5} \mathrm{Et}$ quia nos omnes miseri et peccatores non sumus digni nominare te, suppliciter exoramus, ut Dominus noster Jesus Christus Filius tuus dilectus, in quo tibi bene complacuit (cfr. Mt 17,5), una cum Spiritu Sancto Paraclito gratias agat tibi, sicut tibi et ipsi placet, pro omnibus, qui tibi semper sufficit ad omnia, per quem nobis tanta fecisti. Alleluia.

${ }^{6}$ Et gloriosam matrem beatissimam Mariam semper Virginem, beatum Michaelem, Gabrielem et Raphaelem et omnes choros beatorum seraphim, cherubim, thronorum, dominationum, principatuum, potestatum (cfr. Col 1,15), virtutum, angelorum, archangelorum, beatum Joannem Baptistam, Joannem Evangelistam, Petrum, Paulum et beatos patriarchas, prophetas, Innocentes, apostolos, evangelistas, discipulos, martyres, confessores, virgines, beatos Eliam et Enoch et omnes sanctos, qui fuerunt et erunt et sunt propter tuum amorem humiliter deprecamur, ut, sicut tibi placet, pro his tibi gratias referant summo vero Deo, aeterno et vivo, cum Filio tuo carissimo Domino nostro Jesu Christo et Spiritu Sancto Paraclito in saecula saeculorum (Apoc 19,3). Amen. Alleluia (Apoc 19,4).

${ }^{7}$ Et Domino Deo universos intra sanctam ecclesiam catholicam et apostolicam servire volentes et omnes sequentes ordines: sacerdotes, diaconos, subdiaconos, acolythos, exorcistas, lectores, ostiarios et omnes 
clericos, universos religiosos et religiosas, omnes conversos et parvulos, pauperes et egenos, reges et principes, laboratores et agricolas, servos et dominos, omnes virgines et continentes et maritatas, laicos, masculos et feminas, omnes infantes, adolescentes, iuvenes et senes, sanos et infirmos, omnes pusillos et magnos, et omnes populos, gentes, tribus et linguas (cfr. Apoc 7,9), omnes nationes et omnes homines ubicumque terrarum, qui sunt et erunt, humiliter rogamus et supplicamus nos omnes fratres minores, servi inutiles (LC 17,10), ut omnes in vera fide et poenitentia perseveremus, quia aliter nullus salvari potest.

${ }^{8}$ Omnes diligamus ex toto corde, ex tota anima, ex tota mente, ex tota virtute (cfr. Mc 12,30) et fortitudine, ex toto intellectu (cfr. Mc 12,33), ex omnibus viribus (cfr. Lc 10,27), toto nisu, toto affectu, totis visceribus, totis desideriis et voluntatibus Dominum Deum (Mc 12,30 par.), qui totum corpus, totam animam et totam vitam dedit et dat omnibus nobis, qui nos creavit, redemit et sua sola misericordia salvabit (cfr. Tob 13,5), qui nobis miserabilibus et miseris, putridis et foetidis, ingratis et malis omnia bona fecit et facit.

${ }^{9}$ Nihil ergo aliquid aliud desideremus, nihil aliud velimus, nihil aliud placeat et delectet nos nisi Creator et Redemptor et Salvator noster, solus verus Deus, qui est plenum bonum, omne bonum, totum bonum, verum et summum bonum, qui solus est bonus (cfr. Lc 18,19), pius, mitis, suavis et dulcis, qui solus est sanctus, iustus, verus, sanctus et rectus, qui solus est benignus, innocens, mundus, a quo et per quem et in quo (cfr. Rom 11,36) est omnis venia, omnis gratia, omnis gloria omnium poenitentium et iustorum, ommium beatorum in caelis congaudentium. ${ }^{10} \mathrm{Nihil}$ ergo impediat, nihil separet, nihil interpolet. ${ }^{11}$ Ubique nos omnes omni loco, omni hora et omni tempore, quotidie et continue credamus veraciter et humiliter et in corde teneamus et amemus, honoremus, adoremus, serviamus, laudemus et benedicamus, glorificemus et superexaltemus, magnificemus et gratias agamus altissimo et summo Deo aeterno, trinitati et unitati, Patri et Filio et Spiritui Sancto, creatori omnium et salvatori omnium in se credentium et sperantium et diligentium eum, qui sine initio et sine fine immutabilis, invisibilis, inenarrabilis, ineffabilis, incomprehensibilis, investigabilis (cfr. Rom 11,33), benedictus, laudabilis, gloriosus, superexaltatus (cfr. Dan 3,52), sublimis, excelsus, suavis, amabilis, delectabilis et totus super omnia desiderabilis in saecula. Amen. 
${ }^{1}$ In nomine Domini! Rogo omnes fratres, ut addiscant tenorem et sensum eorum quae in ista vita ad salvationem animae nostrae scripta sunt, et ista frequenter ad memoriam reducant. ${ }^{2} \mathrm{Et}$ exoro Deum, ut ipse, qui est omnipotens, trinus et unus, benedicat omnes docentes, discentes, habentes, recordantes et operantes ista, quoties repetunt et faciunt quae ibi ad salutem animae nostrae scripta sunt, ${ }^{3}$ et deprecor omnes cum osculo pedum, ut multum diligant, custodiant et reponant. ${ }^{4}$ Et ex parte Dei omnipotentis et domini papae et per obedientiam ego frater Franciscus firmiter praecipio et iniungo, ut ex his, quae in ista vita scripta sunt, nullus minuat vel in ipsa scriptum aliquod desuper addat (cfr. Deut 4,2; 12,32), nec aliam regulam fratres habeant.

${ }^{5}$ Gloria Patri et Filio et Spiritui Sancto, sicut erat in principio et nunc et semper et in saecula saeculorum. Amen.

\section{REGULA BULLATA ${ }^{400}[$ RegB]}

[Caput I] In nomine Domini! Incipit vita Minorum Fratrum:

${ }^{1}$ Regula et Vita Minorum Fratrum haec est, scilicet Domini nostri Jesu Christi sanctum Evangelium observare vivendo in obedientia, sine proprio et in castitate. ${ }^{2}$ Frater Franciscus promittit obedientiam et reverentiam domino papae Honorio ac successoribus eius canonice intrantibus et Ecclesiae Romanae. ${ }^{3} \mathrm{Et}$ alii fratres teneantur fratri Francisco et eius successoribus obedire.

[Caput II] De his qui volunt vitam istam accipere, et qualiter recipi debeant.

${ }^{1} \mathrm{Si}$ qui voluerint hanc vitam accipere et venerint ad fratres nostros, mittant eos ad suos ministros provinciales, quibus solummodo et non aliis recipiendi fratres licentia concedatur. ${ }^{2}$ Ministri vero diligenter examinent eos de fide catholica et ecclesiasticis sacramentis. ${ }^{3} \mathrm{Et}$ si haec omnia credant et velint

${ }^{400}$ IDEM, Ibidem, pp. 169-181. 
ea fideliter confiteri et usque in finem firmiter observare ${ }^{4}$ et uxores non habent vel, si habent, et iam monasterium intraverint uxores vel licentiam eis dederint auctoritate diocesani episcopi, voto continentiae iam emisso, et illius sint aetatis uxores, quod non possit de eis oriri suspicio, ${ }^{5}$ dicant illis verbum sancti Evangelii (cfr. Mt 19,21 par), quod vadant et vendant omnia sua et ea studeant pauperibus erogare. ${ }^{6}$ Quod si facere non potuerint, sufficit eis bona voluntas. ${ }^{7}$ Et caveant fratres et eorum ministri, ne solliciti sint de rebus suis temporalibus, ut libere faciant de rebus suis, quidquid Dominus inspiraverit eis. ${ }^{8} \mathrm{Si}$ tamen consilium requiratur, licentiam habeant ministri mittendi eos ad aliquos Deum timentes, quorum consilio bona sua pauperibus erogentur. ${ }^{9}$ Postea concedant eis pannos probationis, videlicet duas tunicas sine caputio et cingulum et braccas et caparonem usque ad cingulum, ${ }^{10}$ nisi eisdem ministris aliud secundum Deum aliquando videatur. ${ }^{11}$ Finito vero anno probationis, recipiantur ad obedientiam promittentes vitam istam semper et regulam observare. ${ }^{12} \mathrm{Et}$ nullo modo licebit eis de ista religione exire iuxta mandatum domini papae, ${ }^{13}$ quia secundum sanctum Evangelium nemo mittens manum ad aratrum et aspiciens retro aptus est regno Dei (Lc 9,62). ${ }^{14} \mathrm{Et}$ illi qui iam promiserunt obedientiam habeant unam tunicam cum caputio et aliam sine caputio qui voluerint habere. ${ }^{15} \mathrm{Et}$ qui necessitate coguntur possint portare calciamenta. ${ }^{16} \mathrm{Et}$ fratres omnes vestimentis vilibus induantur et possint ea repeciare de saccis et aliis peciis cum benedictione Dei. ${ }^{17}$ Quos moneo et exhortor, ne despiciant neque iudicent homines, quos vident mollibus vestimentis et coloratis indutos, uti cibis et potibus delicatis, sed magis unusquisque iudicet et despiciat semetipsum.

[Caput III] De divino officio et ieiunio, et quomodo fratres debeant ire per mundum.

${ }^{1}$ Clerici faciant divinum officium secundum ordinem sanctae Romanae Ecclesiae excepto psalterio, ${ }^{2}$ ex quo habere poterunt breviaria. ${ }^{3}$ Laici vero dicant viginti quattuor Pater noster pro matutino, pro laude quinque, pro prima, tertia, sexta, nona, pro qualibet istarum septem, pro vesperis autem duodecim, pro completorio septem; ${ }^{4}$ et orent pro defunctis. ${ }^{5} \mathrm{Et}$ ieiunent a festo Omnium Sanctorum usque ad Nativitatem Domini. ${ }^{6}$ Sanctam vero quadragesimam, quae 
incipit ab Epiphania usque ad continuos quadraginta dies, quam Dominus suo sancto ieiunio consecravit (cfr. Mt 4,2), qui voluntarie eam ieiunant benedicti sint a Domino, et qui nolunt non sint astricti. ${ }^{7}$ Sed aliam usque ad Resurrectionem Domini ieiunent. ${ }^{8}$ Aliis autem temporibus non teneantur nisi sexta feria ieiunare. ${ }^{9}$ Tempore vero manifestae necessitatis non teneantur fratres ieiunio corporali. ${ }^{10}$ Consulo vero, moneo et exhortor fratres meos in Domino Jesu Christo, ut, quando vadunt per mundum, non litigent neque contendant verbis (cfr. 2 Tim 2,14), nec alios iudicent; ${ }^{11}$ sed sint mites, pacifici et modesti, mansueti et humiles, honeste loquentes omnibus, sicut decet. ${ }^{12} \mathrm{Et}$ non debeant equitare, nisi manifesta necessitate vel infirmitate cogantur. ${ }^{13} / n$ quamcumque domum intraverint, primum dicant: Pax huic domui (cfr. Lc 10,5). ${ }^{14}$ Et secundum sanctum Evangelium de omnibus cibis, qui apponuntur eis, liceat manducare (cfr. Lc 10,8).

[Caput IV] Quod fratres non recipiant pecuniam.

${ }^{1}$ Praecipio firmiter fratribus universis, ut nullo modo denarios vel pecuniam recipiant per se vel per interpositam personam. ${ }^{2}$ Tamen pro necessitatibus infirmorum et aliis fratribus induendis per amicos spirituales ministri tantum et custodes sollicitam curam gerant secundum loca et tempora et frigidas regiones, sicut necessitati viderint expedire; ${ }^{3}$ eo semper salvo, ut, sicut dictum est, denarios vel pecuniam non recipiant.

[Caput V] De modo laborandi.

${ }^{1}$ Fratres illi, quibus gratiam dedit Dominus laborandi, laborent fideliter et devote, ${ }^{2}$ ita quod, excluso otio animae inimico, sanctae orationis et devotionis spiritum non exstinguant, cui debent cetera temporalia deservire. ${ }^{3} \mathrm{De}$ mercede vero laboris pro se et suis fratribus corporis necessaria recipiant praeter denarios vel pecuniam ${ }^{4}$ et hoc humiliter, sicut decet servos Dei et paupertatis sanctissimae sectatores.

[Caput VI] Quod nihil approprient sibi fratres, et de eleemosyna petenda et de fratribus infirmis. 
${ }^{1}$ Fratres nihil sibi approprient nec domum nec locum nec aliquam rem. ${ }^{2}$ Et tanquam peregrini et advenae (cfr. 1 Petr 2,11 ) in hoc saeculo in paupertate et humilitate Domino famulantes vadant pro eleemosyna confidenter, ${ }^{3}$ nec oportet eos verecundari, quia Dominus pro nobis se fecit pauperem in hoc mundo (cfr. 2 Cor 8,9). ${ }^{4} \mathrm{Haec}$ est illa celsitudo altissimae paupertatis, quae vos, carissimos fratres meos, heredes et reges regni caelorum instituit, pauperes rebus fecit, virtutibus sublimavit (cfr. Jac 2,5). ${ }^{5} \mathrm{Haec}$ sit portio vestra, quae perducit in terram viventium (cfr. Ps 141,6). ${ }^{6} \mathrm{Cui}$, dilectissimi fratres, totaliter inhaerentes nihil aliud pro nomine Domini nostri Jesu Christi in perpetuum sub caelo habere velitis. ${ }^{7} \mathrm{Et}$, ubicumque sunt et se invenerint fratres, ostendant se domesticos invicem inter se. ${ }^{8} \mathrm{Et}$ secure manifestet unus alteri necessitatem suam, quia, si mater nutrit et diligit filium suum (cfr. 1 Thess 2,7) carnalem, quanto diligentius debet quis diligere et nutrire fratrem suum spiritualem? ${ }^{9} \mathrm{Et}$, si quis eorum in infirmitate ceciderit, alii fratres debent ei servire, sicut vellent sibi serviri (cfr. Mt 7,12).

[Caput VII] De poenitentia fratribus peccantibus imponenda.

${ }^{1} \mathrm{Si}$ qui fratrum, instigante inimico, mortaliter peccaverint, pro illis peccatis, de quibus ordinatum fuerit inter fratres, ut recurratur ad solos ministros provinciales, teneantur praedicti fratres ad eos recurrere quam citius poterint, sine mora. ${ }^{2}$ Ipsi vero ministri, si presbyteri sunt, cum misericordia iniungant illis poenitentiam; si vero presbyteri non sunt, iniungi faciant per alios sacerdotes ordinis, sicut eis secundum Deum melius videbitur expedire. ${ }^{3} \mathrm{Et}$ cavere debent, ne irascantur et conturbentur propter peccatum alicuius, quia ira et conturbatio in se et in aliis impediunt caritatem.

[Caput VIII] De electione generalis ministri huius fraternitatis et de capitulo Pentecostes.

${ }^{1}$ Universi fratres unum de fratribus istius religionis teneantur semper habere generalem ministrum et servum totius fraternitatis et ei teneantur firmiter obedire. ${ }^{2}$ Quo decedente, electio successoris fiat a ministris provincialibus et 
custodibus in capitulo Pentecostes, in quo provinciales ministri teneantur semper insimul convenire, ubicumque a generali ministro fuerit constitutum; ${ }^{3}$ et hoc semel in tribus annis vel ad alium terminum maiorem vel minorem, sicut a praedicto ministro fuerit ordinatum. ${ }^{4} \mathrm{Et}$ si aliquo tempore appareret universitati ministrorum provincialium et custodum, praedictum ministrum non esse sufficientem ad servitium et communem utilitatem fratrum, teneantur praedicti fratres, quibus electio data est, in nomine Domini alium sibi eligere in custodem. ${ }^{5}$ Post capitulum vero Pentecostes ministri et custodes possint singuli, si voluerint et eis expedire videbitur, eodem anno in suis custodiis semel fratres suos ad capitulum convocare.

[Caput IX] De praedicatoribus.

${ }^{1}$ Fratres non praedicent in episcopatu alicuius episcopi, cum ab eo illis fuerit contradictum. ${ }^{2} \mathrm{Et}$ nullus fratrum populo penitus audeat praedicare, nisi a ministro generali huius fraternitatis fuerit examinatus et approbatus, et ab eo officium sibi praedicationis concessum. ${ }^{3}$ Moneo quoque et exhortor eosdem fratres, ut in praedicatione, quam faciunt, sint examinata et casta eorum eloquia (cfr. Ps 11,$7 ; 17,31$ ), ad utilitatem et aedificationem populi, ${ }^{4}$ annuntiando eis vitia et virtutes, poenam et gloriam cum brevitate sermonis; quia verbum abbreviatum fecit Dominus super terram (cfr. Rom 9,28).

[Caput X] De admonitione et correctione fratrum.

${ }^{1}$ Fratres, qui sunt ministri et servi aliorum fratrum, visitent et moneant fratres suos et humiliter et caritative corrigant eos, non praecipientes eis aliquid, quod sit contra animam suam et regulam nostram. ${ }^{2}$ Fratres vero, qui sunt subditi, recordentur, quod propter Deum abnegaverunt proprias voluntates. ${ }^{3}$ Unde firmiter praecipio eis, ut obediant suis ministris in omnibus quae promiserunt Domino observare et non sunt contraria animae et regulae nostrae. ${ }^{4} \mathrm{Et}$ ubicumque sunt fratres, qui scirent et cognoscerent, se non posse regulam spiritualiter observare, ad suos ministros debeant et possint recurrere. ${ }^{5}$ Ministri vero caritative et benigne eos recipiant et tantam familiaritatem habeant circa ipsos, ut dicere possint eis et facere sicut domini servis suis; ${ }^{6}$ nam ita debet 
esse, quod ministri sint servi omnium fratrum. ${ }^{7}$ Moneo vero et exhortor in Domino Jesu Christo, ut caveant fratres ab omni superbia, vana gloria, invidia, avaritia (cfr. Lc 12,15), cura et sollicitudine huius saeculi (cfr. Mt 13,22), detractione et murmuratione, et non curent nescientes litteras litteras discere; ${ }^{8}$ sed attendant, quod super omnia desiderare debent habere Spiritum Domini et sanctam eius operationem, ${ }^{9}$ orare semper ad eum puro corde et habere humilitatem, patientiam in persecutione et infirmitate ${ }^{10}$ et diligere eos qui nos persequuntur et reprehendunt et arguunt, quia dicit Dominus: Diligite inimicos vestros et orate pro persequentibus et calumniantibus vos (cfr. Mt 5,44). ${ }^{11}$ Beati qui persecutionem patiuntur propter iustitiam, quoniam ipsorum est regnum caelorum (Mt 5,10). ${ }^{12}$ Qui autem perseveraverit usque in finem hic salvus erit (Mt 10,22).

[Caput XI] Quod fratres non ingrediantur monasteria monacharum.

${ }^{1}$ Praecipio firmiter fratribus universis, ne habeant suspecta consortia vel consilia mulierum, ${ }^{2}$ et ne ingrediantur monasteria monacharum praeter illos, quibus a sede apostolica concessa est licentia specialis; ${ }^{3}$ nec fiant compatres virorum vel mulierum nec hac occasione inter fratres vel de fratribus scandalum oriatur.

[Caput XII] De euntibus inter saracenos et alios infideles.

${ }^{1}$ Quicumque fratrum divina inspiratione voluerint ire inter saracenos et alios infideles petant inde licentiam a suis ministris provincialibus. ${ }^{2}$ Ministri vero nullis eundi licentiam tribuant, nisi eis quos viderint esse idoneos ad mittendum. ${ }^{3} \mathrm{Ad}$ haec per obedientiam iniungo ministris, ut petant a domino papa unum de sanctae Romanae Ecclesiae cardinalibus, qui sit gubernator, protector et corrector istius fraternitatis, ${ }^{4}$ ut semper subditi et subiecti pedibus eiusdem sanctae Ecclesiae stabiles in fide (cfr. Col 1,23) catholica paupertatem et humilitatem et sanctum evangelium Domini nostri Jesu Christi, quod firmiter promisimus, observemus. 


\section{TESTAMENTUM ${ }^{401}[$ Test]}

${ }^{1}$ Dominus ita dedit mihi fratri Francisco incipere faciendi poenitentiam: quia, cum essem in peccatis, nimis mihi videbatur amarum videre leprosos. ${ }^{2} \mathrm{Et}$ ipse Dominus conduxit me inter illos et feci misericordiam cum illis. ${ }^{3} \mathrm{Et}$ recedente me ab ipsis, id quod videbatur mihi amarum, conversum fuit mihi in dulcedinem animi et corporis; et postea parum steti et exivi de saeculo. ${ }^{4} \mathrm{Et}$ Dominus dedit mihi talem fidem in ecclesiis, ut ita simpliciter orarem et dicerem: ${ }^{5}$ Adoramus te, Domine Jesu Christe et ad omnes ecclesias tuas, quae sunt in toto mundo, et benedicimus tibi, quia per sanctam crucem tuam redimisti mundum. ${ }^{6}$ Postea Dominus dedit mihi et dat tantam fidem in sacerdotibus, qui vivunt secundum formam sanctae ecclesiae Romanae propter ordinem ipsorum, quod si facerent mihi persecutionem, volo recurrere ad ipsos. ${ }^{7} \mathrm{Et}$ si haberem tantam sapientiam, quantam Salomon habuit, et invenirem pauperculos sacerdotes huius saeculi, in parochiis, quibus morantur, nolo praedicare ultra voluntatem ipsorum. ${ }^{8} \mathrm{Et}$ ipsos et omnes alios volo timere, amare et honorare sicut meos dominos. ${ }^{9} \mathrm{Et}$ nolo in ipsis considerare peccatum, quia Filium Dei discerno in ipsis, et domini mei sunt. ${ }^{10} \mathrm{Et}$ propter hoc facio, quia nihil video corporaliter in hoc saeculo de ipso altissimo Filio Dei, nisi sanctissimum corpus et sanctissimum sanguinem suum, quod ipsi recipiunt et ipsi soli aliis ministrant. ${ }^{11} \mathrm{Et}$ haec sanctissima mysteria super omnia volo honorari, venerari et in locis pretiosis collocari. ${ }^{12}$ Sanctissima nomina et verba eius scripta, ubicumque invenero in locis illicitis, volo colligere et rogo, quod colligantur et in loco honesto collocentur. ${ }^{13} \mathrm{Et}$ omnes theologos et qui ministrant sanctissima verba divina, debemus honorare et venerari, sicut qui ministrant nobis spiritum et vitam (cfr. Joa 6,64).

${ }^{14}$ Et postquam Dominus dedit mihi de fratribus, nemo ostendebat mihi, quid deberem facere, sed ipse Altissimus revelavit mihi, quod deberem vivere secundum formam sancti Evangelii. ${ }^{15} \mathrm{Et}$ ego paucis verbis et simpliciter feci scribi et dominus papa confirmavit mihi. ${ }^{16} \mathrm{Et}$ illi qui veniebant ad recipiendam vitam, omnia quae habere poterant (Tob 1,3), dabant pauperibus; et erant contenti tunica una, intus et foris repeciata, cum cingulo et braccis. ${ }^{17} \mathrm{Et}$

${ }^{401}$ IDEM, Ibidem, pp. 225-235. 
nolebamus plus habere. ${ }^{18}$ Officium dicebamus clerici secundum alios clericos, laici dicebant: Pater noster; et satis libenter manebamus in ecclesiis. ${ }^{19} \mathrm{Et}$ eramus idiotae et subditi omnibus. ${ }^{20} \mathrm{Et}$ ego manibus meis laborabam, et volo laborare; et omnes alii fratres firmiter volo, quod laborent de laboritio, quod pertinet ad honestatem. ${ }^{21}$ Qui nesciunt, discant, non propter cupiditatem recipiendi pretium laboris, sed propter exemplum et ad repellendam otiositatem. ${ }^{22} \mathrm{Et}$ quando non daretur nobis pretium laboris, recurramus ad mensam Domini, petendo eleemosynam ostiatim. ${ }^{23}$ Salutationem mihi Dominus revelavit, ut diceremus: Dominus det tibi pacem. ${ }^{24}$ Caveant sibi fratres, ut ecclesias, habitacula paupercula et omnia, quae pro ipsis construuntur, penitus non recipiant, nisi essent, sicut decet sanctam paupertatem, quam in regula promisimus, semper ibi hospitantes sicut advenae et peregrini (cfr. 1 Petr 2,11). ${ }^{25}$ Praecipio firmiter per obedientiam fratribus universis, quod ubicumque sunt, non audeant petere aliquam litteram in curia Romana per se neque per interpositam personam, neque pro ecclesia neque pro alio loco neque sub specie praedicationis neque pro persecutione suorum corporum; ${ }^{26}$ sed ubicumque non fuerint recepti, fugiant in aliam terram ad faciendam poenitentiam cum benedictione Dei.

${ }^{27} \mathrm{Et}$ firmiter volo obedire ministro generali huius fraternitatis et alio guardiano, quem sibi placuerit mihi dare. ${ }^{28} \mathrm{Et}$ ita volo esse captus in manibus suis, ut non possim ire vel facere ultra obedientiam et voluntatem suam, quia dominus meus est. ${ }^{29} \mathrm{Et}$ quamvis sim simplex et infirmus, tamen semper volo habere clericum, qui mihi faciat officium, sicut in regula continetur. ${ }^{30} \mathrm{Et}$ omnes alii fratres teneantur ita obedire guardianis suis et facere officium secundum regulam. ${ }^{31}$ Et qui inventi essent, quod non facerent officium secundum regulam, et vellent alio modo variare, aut non essent catholici, omnes fratres, ubicumque sunt, per obedientiam teneantur, quod ubicumque invenerint aliquem ipsorum, proximiori custodi illius loci, ubi ipsum invenerint, debeant repraesentare. ${ }^{32} \mathrm{Et}$ custos firmiter teneatur per obedientiam ipsum fortiter custodire, sicuti hominem in vinculis die noctuque, ita quod non possit eripi de manibus suis, donec propria sua persona ipsum repraesentet in manibus sui ministri. ${ }^{33} \mathrm{Et}$ minister firmiter teneatur per obedientiam mittendi ipsum per tales fratres, quod die noctuque custodiant ipsum sicuti hominem in vinculis, donec repraesentent ipsum coram domino Ostiensi, qui est dominus, protector et corrector totius 
fraternitatis. ${ }^{34} \mathrm{Et}$ non dicant fratres: Haec est alia regula; quia haec est recordatio, admonitio, exhortatio et meum testamentum, quod ego frater Franciscus parvulus facio vobis fratribus meis benedictis propter hoc, ut regulam, quam Domino promisimus, melius catholice observemus.

${ }^{35} \mathrm{Et}$ generalis minister et omnes alii ministri et custodes per obedientiam teneantur, in istis verbis non addere vel minuere. ${ }^{36} \mathrm{Et}$ semper hoc scriptum habeant secum iuxta regulam. ${ }^{37} \mathrm{Et}$ in omnibus capitulis, quae faciunt, quando legunt regulam, legant et ista verba. ${ }^{38} \mathrm{Et}$ omnibus fratribus meis clericis et laicis praecipio firmiter per obedientiam, ut non mittant glossas in regula neque in istis verbis dicendo: Ita volunt intelligi. ${ }^{39}$ Sed sicut dedit mihi Dominus simpliciter et pure dicere et scribere regulam et ista verba, ita simpliciter et sine glossa intelligatis et cum sancta operatione observetis usque in finem.

${ }^{40} \mathrm{Et}$ quicumque haec observaverit, in caelo repleatur benedictione altissimi Patris et in terra repleatur benedictione dilecti Filii sui cum sanctissimo Spiritu Paraclito et omnibus virtutibus caelorum et omnibus sanctis. ${ }^{41} \mathrm{Et}$ ego frater Franciscus parvulus, vester servus, quantumcumque possum, confirmo vobis intus et foris istam sanctissimam benedictionem. 